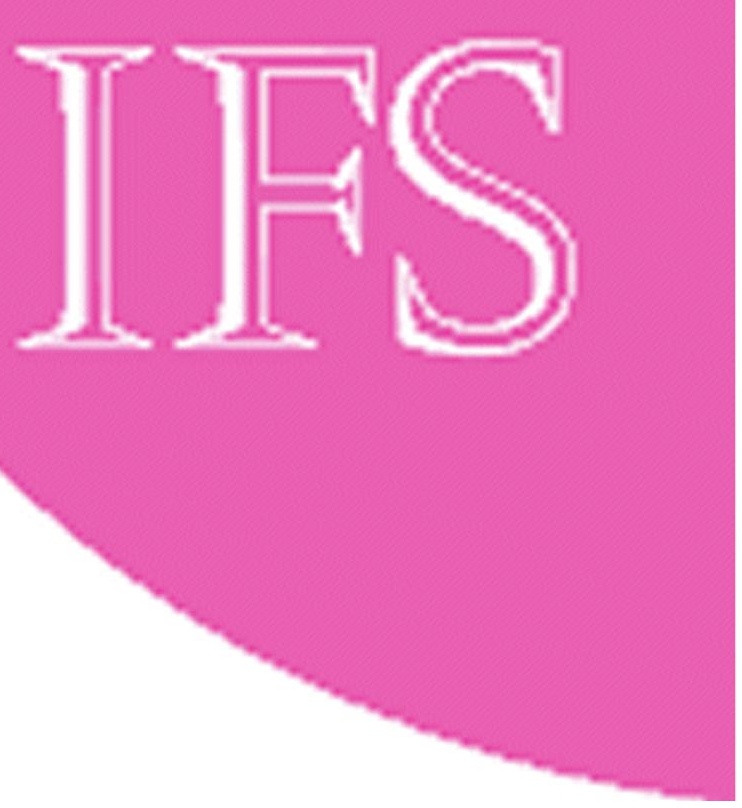

\title{
TAXING Profits IN A CHANGING WORLD
}

Lucy Chennells Rachel Griffith 


\title{
Taxing Profits in a Changing World
}

\author{
Lucy Chennells \\ Rachel Griffith
}

The Institute for Fiscal Studies

7 Ridgmount Street

London WC1E 7AE 


\section{Published by \\ The Institute for Fiscal Studies \\ 7 Ridgmount Street \\ London WC1E 7AE \\ tel. (44) 1716363784 \\ fax (44) 1713234780 \\ email: mailbox@ifs.org.uk \\ internet: http//www.ifs.org.uk}

(C) The Institute for Fiscal Studies, September 1997

ISBN 1-873357-73-7

\section{Printed by}

KKS Printing

The Printworks

12-20 Rosina Street

London E9 6JE 


\section{Preface}

The authors would like to thank Stephen Bond, Michael P. Devereux, Silvia Giannini and Jack Mintz for helpful comments on this and previous versions. They are indebted to Katrina Gotch and Rameet Sangha for excellent assistance in collecting the data and to Price Waterhouse for allowing them access to its library, and in particular to Sergio Ramos. This work was funded by the ESRC Centre for the Microeconomic Analysis of Fiscal Policy at the Institute for Fiscal Studies and the Institute of Chartered Accountants in England and Wales. All errors remain the authors'.

Lucy Chennells is a Senior Research Officer at the Institute for Fiscal Studies.

Rachel Griffith is a Programme Co-ordinator at the Institute for Fiscal Studies. 



\section{Contents}

List of Tables vii

List of Figures $\quad$ ix

Summary 1

1 Introduction 11

1.1 Foreign investment 13

1.2 Tax measures $\quad 20$

1.3 Structure of the report 25

2 Tax Reforms 26

3 Tax Revenue 31

4 Effective Tax Rates 36

4.1 Effective tax rates for domestic investment 41

4.2 Effective tax rates for foreign direct investment 54

4.3 Average tax rates using accounting data 62

5 Explaining Tax-Setting Behaviour 65

5.1 Empirical predictions 66

5.2 Country size and openness 69

5.3 A dominant capital exporter $\quad 72$

5.4 Less than perfectly mobile capital 76

5.5 Capital taxes as an anti-avoidance measure $\quad 78$

6 Conclusion $\quad 80$

Appendix A Methodology 82

Appendix B Description of country appendices 98

Appendix C Australia 104

Appendix D Canada 11

Appendix E France 119

Appendix F Germany 126

Appendix G Ireland 133

Appendix H Italy 140

Appendix I Japan 146

Appendix J Spain 154 
Appendix K UK

161

Appendix L US

168

References

176 


\section{List of Tables}

$\begin{array}{lll}\text { Table 1.1 Growth rates } & 17\end{array}$

Table 1.2 Treatment of retained profits in definition of 18 FDI

Table 1.3 US multinationals' sources of finance 18

Table 2.1 Summary of corporation tax reforms 1979-94 28

Table 4.1 Within-country variation in domestic EMTR 44

Table 4.2 Means and standard deviations of domestic 46 EMTRs

Table 4.3 Means and standard deviations of domestic 50 EMTRs: inflation varies across countries and time

Table 4.4 Means and standard deviations of domestic 53 EATRs

Table 4.5 Means and mean standard deviations of source 58 and residence country EMTRs and EATRs

Table 4.6 Average tax rates 63

Table 5.1 Empirical predictions concerning tax rates 67

Table 5.2 Tabulation by size $\quad 70$

Table 5.3 Openness indicator $\quad 71$

$\begin{array}{lll}\text { Table } 5.4 & \text { Tabulation by size and openness } & 72\end{array}$

$\begin{array}{lll}\text { Table A.1 Proportion of inward FDI } & 84\end{array}$

Table A.2 Proportion of outward FDI $\quad 85$

$\begin{array}{lll}\text { Table A.3 Discount rates } & 91\end{array}$

Table A.4 Treatment of foreign source income 92

Table A.5 Finance and asset weights, and economic 92 depreciation rates

Table A.6 Sample size from Global Vantage 94

Table B.1 Valuation method for inventories 101

Table B.2 Method of integrating corporate and personal 102 income taxes

Table B.3 Treatment of foreign source income 103

Table C.1 Australian tax rates and NPV of allowances 104 
Table C.2 Australian domestic effective marginal tax wedge

$\begin{array}{lll}\text { Table C.3 Australian effective tax rates } & 107\end{array}$

Table D.1 Canadian tax rates and NPV of allowances 111

Table D.2 Canadian domestic effective marginal tax 112

$\begin{array}{lll}\text { Table D.3 Canadian effective tax rates } & 114\end{array}$

Table E.1 French tax rates and NPV of allowances 119

Table E.2 French domestic effective marginal tax wedge 120

$\begin{array}{lll}\text { Table E.3 French effective tax rates } & 121\end{array}$

Table F.1 German tax rates and NPV of allowances 126

Table F.2 German domestic effective marginal tax wedge 127

Table F.3 German effective tax rates 129

Table G.1 Irish tax rates and NPV of allowances 134

Table G.2 Irish domestic effective marginal tax wedge 135

$\begin{array}{lll}\text { Table G.3 Irish effective tax rates } & 136\end{array}$

Table H.1 Italian tax rates and NPV of allowances 140

Table H.2 Italian domestic effective marginal tax wedge 141

Table H.3 Italian effective tax rates 143

Table I.1 Composition of Japanese statutory corporate 147

$\begin{array}{lll} & \text { income tax rate } \\ \text { Table I.2 } & \text { Japanese tax rates and NPV of allowances } & 148\end{array}$

Table I.3 Japanese domestic effective marginal tax 149

$\begin{array}{lll} & \text { wedge } & 150\end{array}$

Table J.1 Spanish tax rates and NPV of allowances 154

Table J.2 Spanish domestic effective marginal tax wedge 155

$\begin{array}{lll}\text { Table J.3 Spanish effective tax rates } & 157\end{array}$

Table K.1 UK tax rates and NPV of allowances 161

Table K.2 UK domestic effective marginal tax wedge 162

$\begin{array}{lll}\text { Table K.3 UK effective tax rates } & 164\end{array}$

Table L.1 US tax rates and NPV of allowances 168

Table L.2 US domestic effective marginal tax wedge 169

$\begin{array}{lll}\text { Table L.3 US effective tax rates } & 171\end{array}$

viii 


\section{List of Figures}

Figure 1 Inward FDI flow/GDP 2

Figure 2 Statutory tax rate on retained earnings 4

Figure $3 \quad$ NPV of depreciation allowances for plant and 4

Figure 4 Corporate income tax revenue as a percentage 5 of GDP

Figure 5 Domestic effective marginal tax rates 6

Figure 6 Source country effective marginal tax rates 8

Figure 7 Residence country effective marginal tax rates 9

Figure 1.1 Inward FDI flow/GDP 15

Figure 1.2 Outward FDI flow/GDP 16

Figure 1.3 Long-term real interest rates 19

Figure 2.1 Statutory tax rate on retained earnings 27

Figure 2.2 NPV of depreciation allowances for plant and 29 machinery

Figure 3.1 Corporate income tax revenue as a percentage 32 of GDP

Figure 3.2 Corporate income tax revenue as a percentage of total tax revenue

Figure 4.1 Domestic effective marginal tax rates 42

Figure 4.2 Domestic effective marginal tax rates: 48

$\begin{array}{lll}\text { Figure 4.3 Inflation rates } & 49\end{array}$

Figure 4.4 Domestic effective average tax rates 52

Figure 4.5 Source country effective marginal tax rates $\quad 56$

Figure 4.6 Source country effective average tax rates $\quad 57$

Figure 4.7 Residence country effective marginal tax rates 60

Figure 4.8 Residence country effective average tax rates 61

Figure 4.9 Residence country average tax rates 62 (accounting data)

Figure 5.1 EMTR on investment from the US into other 74

$\begin{array}{lll} & \text { countries } & 109\end{array}$ 
$\begin{array}{lll}\text { Figure C.2 FDI from Australia } & 110\end{array}$

$\begin{array}{lll}\text { Figure D.1 FDI into Canada } & 117\end{array}$

$\begin{array}{lll}\text { Figure D.2 FDI from Canada } & 117\end{array}$

Figure E.1 FDI into France 124

Figure E.2 FDI from France 124

Figure F.1 FDI into Germany 131

Figure F.2 FDI from Germany 131

Figure G.1 FDI into Ireland 138

Figure H.1 FDI into Italy 145

Figure H.2 FDI from Italy 145

Figure I.1 FDI into Japan 152

Figure I.2 FDI from Japan 153

$\begin{array}{lll}\text { Figure J.1 FDI into Spain } & 159\end{array}$

Figure J.2 FDI from Spain 159

Figure K.1 FDI into the UK 166

$\begin{array}{lll}\text { Figure K.2 } & \text { FDI from the UK } & 167\end{array}$

$\begin{array}{lll}\text { Figure L.1 FDI into the US } & 174\end{array}$

$\begin{array}{lll}\text { Figure L.2 FDI from the US } & 174\end{array}$ 


\section{SUMMARY}

This report presents new information on the evolution of corporate income taxes in 10 countries - Australia, Canada, France, Germany, Ireland, Italy, Japan, Spain, the UK and the US - over the period 1979 to 1994. It describes how corporate income taxes have changed and addresses the question of whether changes in the international economy might have played a role in shaping these changes. While there is a large theoretical literature that deals with the tax-setting behaviour of governments, there is relatively little evidence on the empirical validity of these models. This report, produced with the support of the Institute of Chartered Accountants in England and Wales, aims to fill that gap by presenting new information describing how tax reforms have affected investment incentives over time and across countries.

A number of measures of corporate income tax are presented, including statutory tax rates, effective marginal and average tax rates, average tax rates calculated from firm-level accounting data and tax revenue statistics. The penultimate chapter of the report considers whether these data are informative in distinguishing between alternative models of tax-setting behaviour. Details of the methodology used in calculating the various tax rates and their interpretation are given in two appendices. Ten country-specific appendices present the details of each measure and discuss some of the major reforms in each country. 
Taxing profits in a changing world

\section{Foreign Direct Investment}

It is now a commonplace statement to say that the economy is becoming more global, but what is meant by this? How has the economic environment changed and how have these changes affected the tax-setting behaviour of governments? The extent to which capital markets can be considered to be more integrated is a contentious issue in the academic literature. Many articles suggest that capital is relatively immobile. Yet most theoretical literature assumes that capital is mobile.

FIGURE 1

Inward FDI flow/GDP

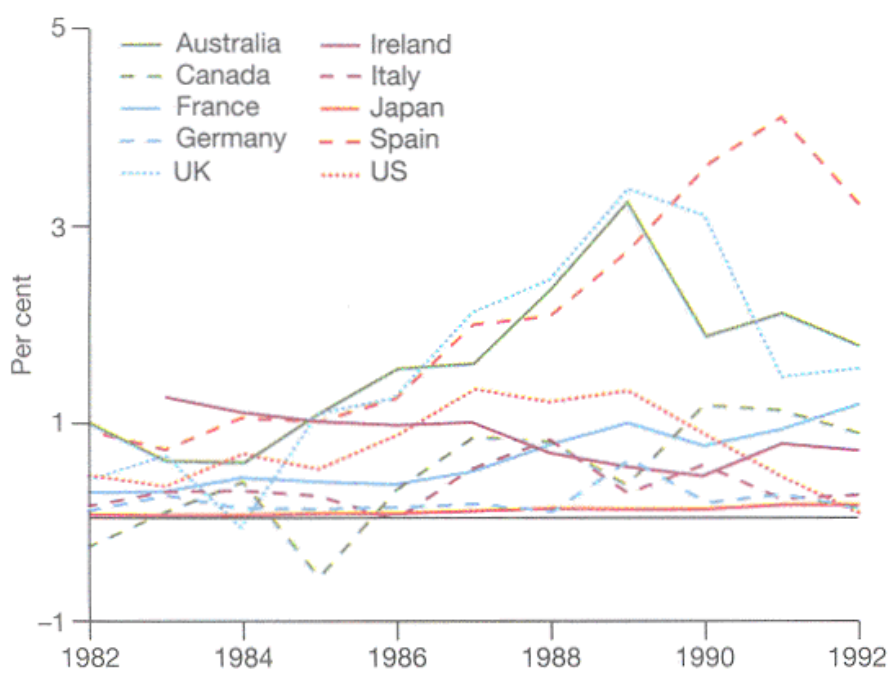

Source: OECD FDI Statistics database.

For most countries, the inward flow of foreign direct investment (FDI) has increased over the 1980s, as shown in Figure 1. However, there are many problems with using FDI flows to compare capital mobility across countries or over time. FDI flows are very volatile and 
the definition is not consistent across countries or over time. One particular problem is whether investment financed by retained earnings or local borrowing by the subsidiary is considered as an FDI flow.

\section{Changes in Corporate Income Tax}

Five measures of corporate income tax are examined. These are (i) the statutory tax rate, (ii) corporate income tax revenues, (iii) the effective marginal tax rate, (iv) the effective average tax rate and (v) an average tax rate constructed using firm-level accounting data. The different measures are informative about a range of issues such as incentives to invest, the behaviour of policymakers and the revenue implications of policy changes. One important caveat about these data is that, although a tax is levied on corporate income, the final incidence of the tax does not necessarily fall on the owners of capital. Determining the final incidence of

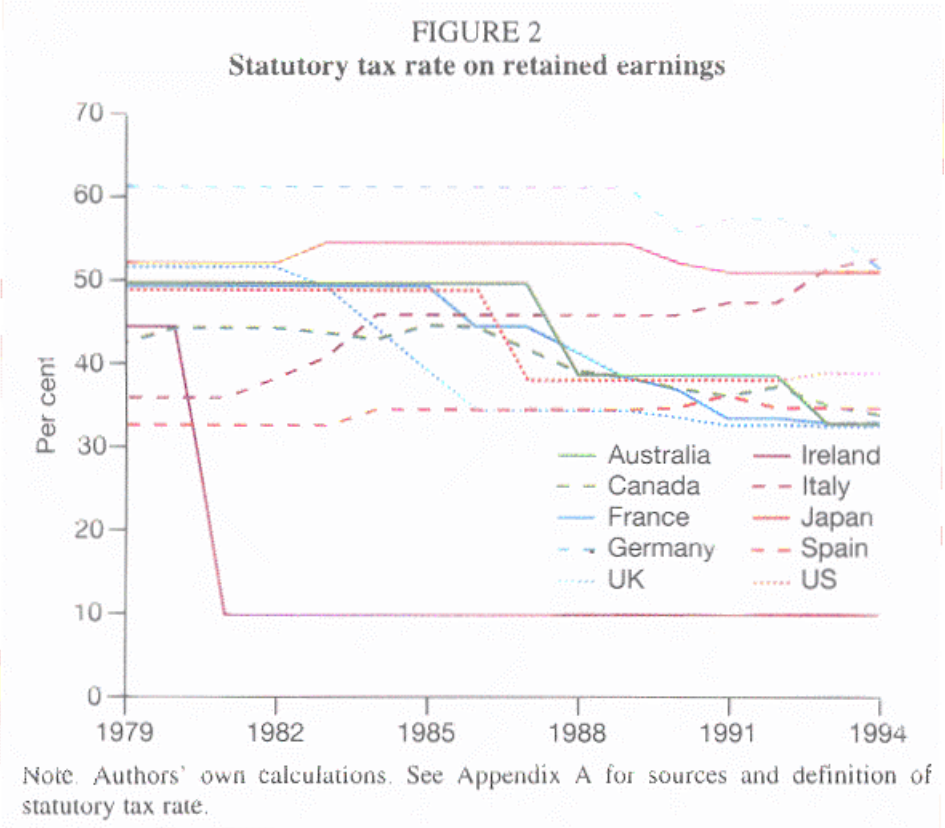


Taxing profits in a changing world

corporate income taxes is a difficult task.

All 10 of the countries considered have experienced some tax reform. The dominant trend in tax reform over the period 1979-94 has been towards a lowering of tax rates, combined with extending the tax base through a reduction in the value of allowances given for investment. Figure 2 shows the statutory tax rate that applies to earnings retained by the company (including surcharges and local corporate income taxes). Statutory tax rates have declined in seven countries and risen in

FIGURE 3

NPV of depreciation allowances for plant and machinery

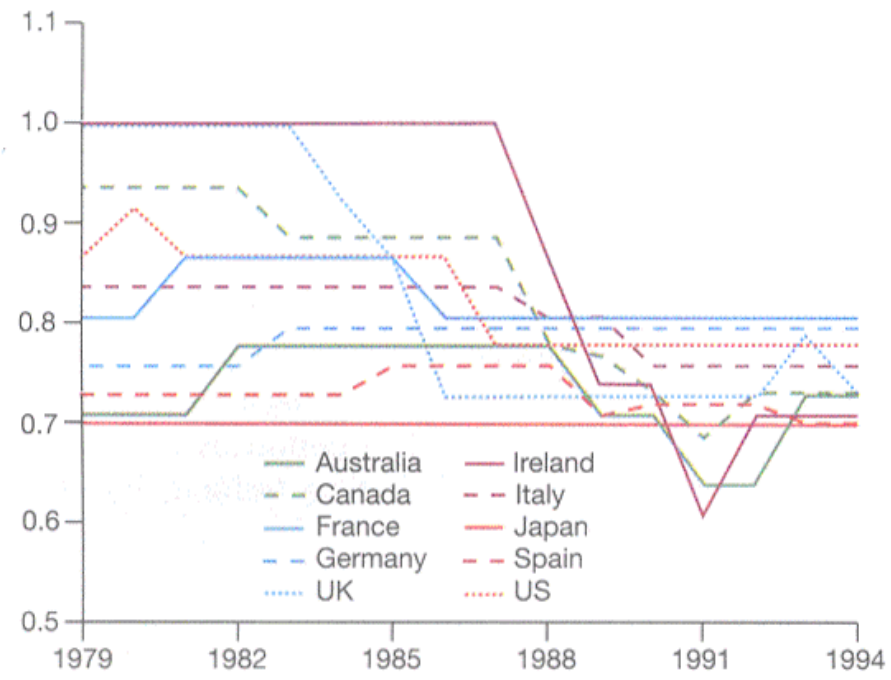

Note: Authors' own calculations. See Appendix A for sources and definitions of depreciation allowances.

three, while the average, excluding Ireland, has fallen from 48 per cent to just over 40 per cent. As an example of how the tax base has changed, Figure 3 shows how the net present value of allowances for plant and machinery has declined over time. 
FIGURE 4

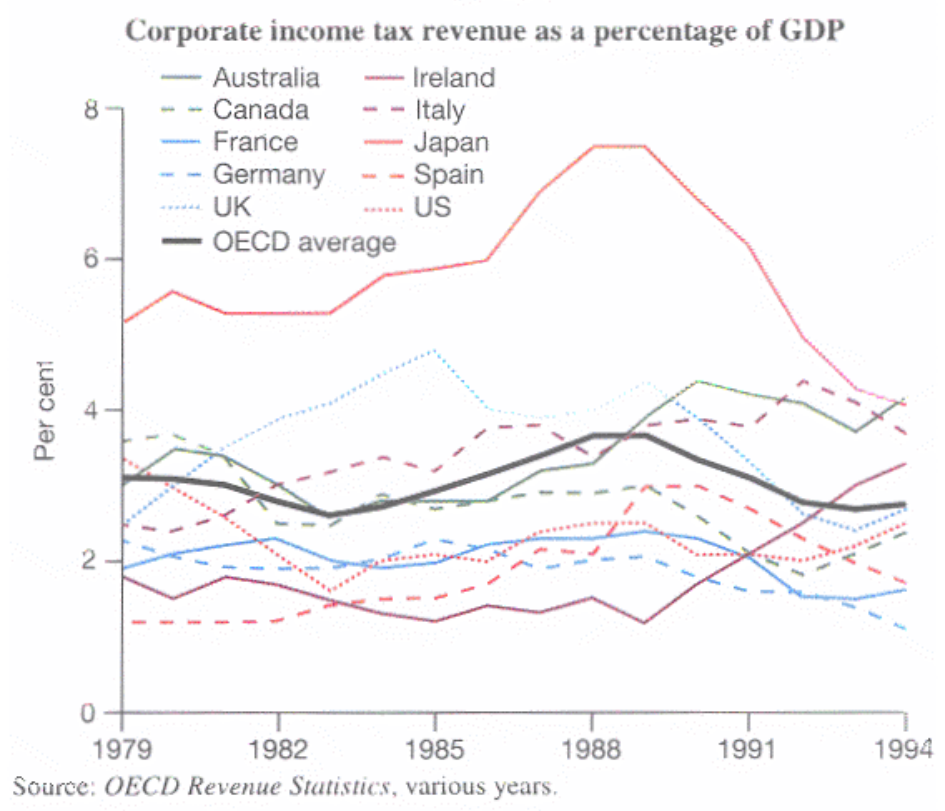

In addition to changes in domestic tax policy, there have been changes to international aspects of the taxation of corporate income. Withholding taxes on repatriated dividend income have fallen from 10 to 6.6 per cent on average, while on interest income they have fallen from 10 to 8 per cent.

The amount of tax revenue collected from corporate income taxes, as a proportion of GDP, has remained relatively constant across the OECD as a whole. However, different countries have experienced quite different patterns of receipts, as shown in Figure 4. 
Taxing profits in a changing world

\section{Impact of Tax Reform on Domestic Effective Tax Rates}

Effective tax rates summarise the impact of the tax system on the required rate of return. Two types of effective tax rate are presented - the effective marginal tax rate (EMTR) and the effective average tax rate (EATR). The EMTR is the effective rate of tax that applies to a marginal investment project, i.e. one that just earns the minimum required rate of return after tax. The EATR is the effective rate of tax that applies to an investment project earning some economic rent, i.e. earning more than the minimum required rate of return after tax. These effective tax rates have been calculated

FIGURE 5

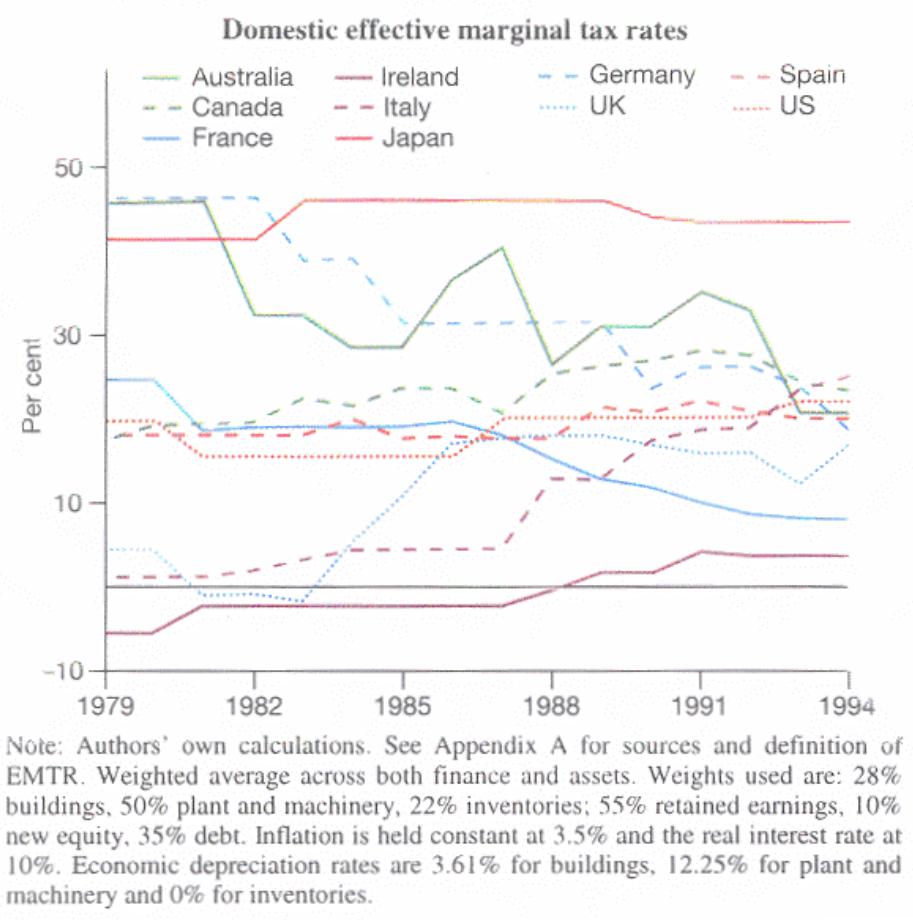


holding inflation and the real interest rate constant across time and over countries to highlight the impact of tax.

The EMTR on domestic investment in each of the 10 countries is shown in Figure 5. The average across all countries remains fairly stable over time, varying between 19.4 per cent and 22.8 per cent. Overall, tax systems have become more neutral with respect to investment in different types of asset and using different types of finance. There is also some evidence of between-country convergence in the EMTR. When the EMTR is calculated using actual inflation rates, there is a much stronger degree of convergence. This is due to the higher variation in inflation rates at the beginning of the period. The EATR does not indicate the same degree of convergence.

Impact of Tax Reform on International Effective Tax Rates

Effective tax rates for an investment made by a parent company in one country (known as the source country) into its wholly-owned subsidiary in another country (known as the residence country) are presented. The source country effective tax rates can be used to compare the favourability of alternative locations, and their variability is an indicator of the extent to which capital import neutrality holds. The residence country can be used to compare the attractiveness of alternative locations for outward investment, and their variability is an indicator of the extent to which capital export neutrality holds.

The source country EMTRs shown in Figure 6 are higher than the domestic EMTRs, indicating that, on average, it is more costly for foreign investors to invest in these countries than it is for domestic investors to do 
Taxing profits in a changing world

\section{FIGURE 6}

Source country effective marginal tax rates

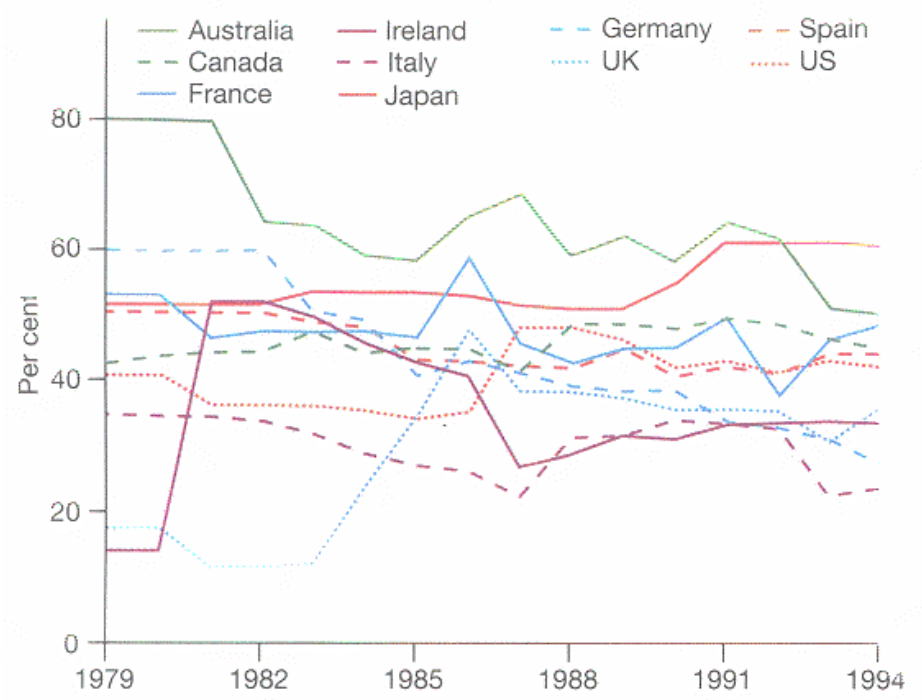

Note: Authors' own calculations. See Appendix A for sources and definition of EMTR. All rates are averaged across finance and assets. Weights used for assets: $28 \%$ buildings, $50 \%$ plant and machinery, $22 \%$ inventories; for parent company source of finance: $55 \%$ retained earnings, $10 \%$ new equity, $35 \%$ debt; for subsidiary source of finance: $33 \%$ retained earnings, $33 \%$ new equity from the parent, $33 \%$ debt from the parent. Inflation is held constant at $3.5 \%$ and the real interest rate at $10 \%$. Economic depreciation rates are $3.61 \%$ for buildings, $12.25 \%$ for plant and machinery and $0 \%$ for inventories. The rate is the weighted average of investment from the nine other countries, weighted by the proportion of inward FDI coming from each country (see Table A.l in Appendix A).

so. This is also true for the EATR. Both the mean source country EMTR and the mean source country EATR fell over the period, while the mean of the standard deviations rose. This increase in the average dispersion of tax rates faced by foreign investors in these countries indicates a reduction in the overall degree of capital import neutrality in these countries.

Similarly, the residence country EMTRs shown in Figure 7 are higher than the domestic EMTRs, although the pattern is quite different. The mean of the residence 
country EMTRs has risen while the mean of the residence country EATRs has fallen over the period. The mean of the individual residence country standard deviations of the EMTR fell, indicating an increase in the degree of capital export neutrality, on average, in these 10 countries. However, this is not true for the EATR.

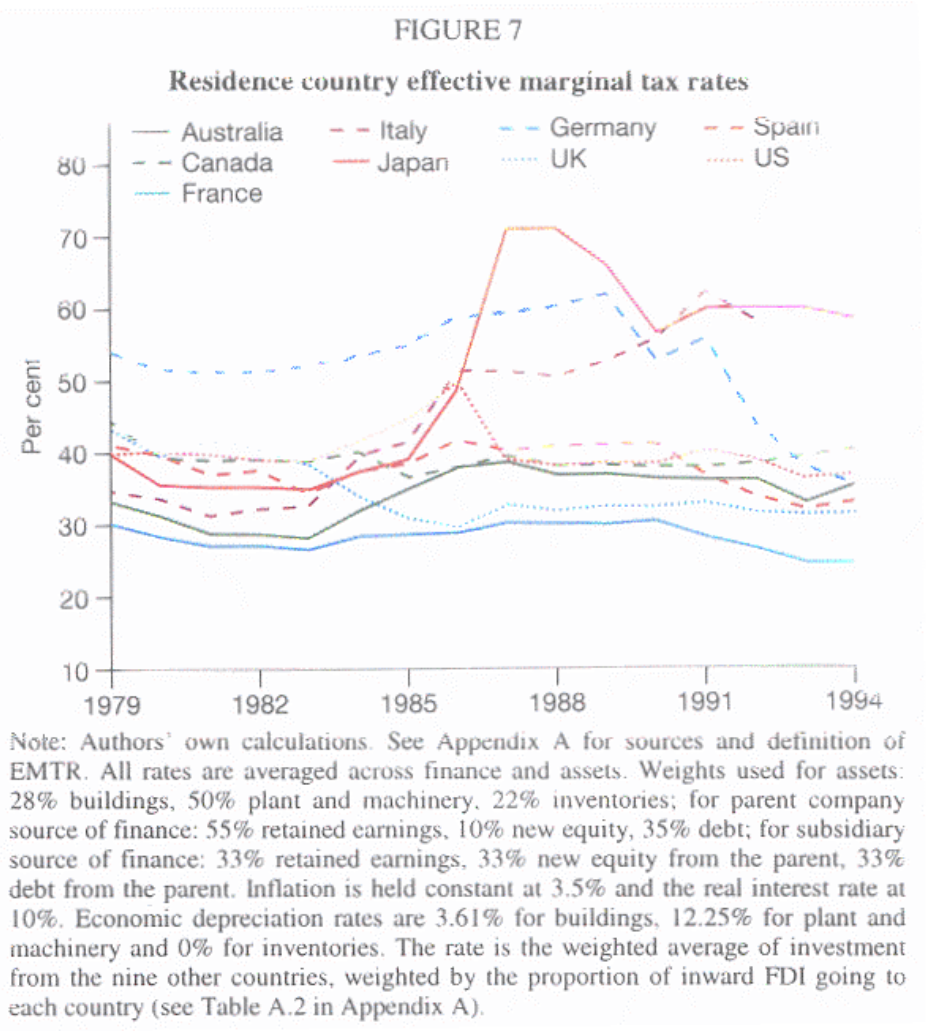

\section{Explaining Tax-Setting Behaviour}

The question addressed in the penultimate chapter of the report is whether the data conform to the predictions of theoretical models. Four main propositions are 


\section{Taxing profits in a changing world}

discussed: that smaller, more open economies should have lower tax rates than larger, closed economies; that capital-importing countries should set the tax rate on inward investment at the same rate as the dominant exporting country; that the tax rate should be related to the degree of mobility of capital; and that capital taxes might play some alternate role to raising taxes, such as ensuring that labour income does not escape taxation. No clear empirical evidence to support any of these predictions is found. None of the evidence presented suggests that tax competition is driving tax rates or revenues to zero, or that there has been a significant erosion of the capital tax base.

On the face of it, the evidence appears inconsistent with a tax competition view of the world. However, there could be many reasons for this. The countries examined in this study are perhaps not the ones where we would expect the largest degree of competition. In addition, tax systems are becoming more complex and many important changes in the tax treatment of capital have not been reflected in the numbers presented here. It is also worth pointing out that only a subset of the tax competition models and none of the models about tax co-ordination have been considered here. What we have done is to set out some of the data and discuss some of the methodological issues that might help inform both empirical and theoretical research in this area in the future. 


\section{CHAPTER 1 \\ Introduction}

The question of how (or indeed whether) corporate income should be taxed has been an issue of much policy debate over the past two decades. During this time, most OECD countries have undertaken reform of one sort or another to their corporate income tax system. At the same time, there has been much discussion about the impact that increasing globalisation of business activity has had on the ability of national governments to set and collect taxes on corporate income. This is an issue over which there has been concern at both the governmental and the intra-governmental level. For example, both the OECD and the EU have recently been considering the issue of 'unfair' or 'harmful' tax competition. Tax competition describes a process whereby governments use fiscal incentives to attract investment, or revenue, away from other alternative locations. The debate has largely focused on defining what is meant by harmful competition and identifying its effects. This has included distinguishing between fair and harmful tax competition, assessing the effectiveness of existing defences against harmful tax competition and attempting to establish ways in which governments acting individually or collectively could ameliorate the negative effects of tax competition.

Previous work by the EU (Ruding Committee, 1992) looked at whether differences in the taxation of corporate income caused major distortions in investment patterns within the EU. The report considered whether competition was likely to eliminate these differences and what harmonisation measures at the Community 


\section{Taxing profits in a changing world}

level might achieve. The main conclusions of the report were that considerable differences did exist and that these differences had a distortionary effect on the foreign location decisions of multinational firms. These empirical findings were based on survey evidence from firms operating within the EU. While some degree of convergence had occurred, the report concluded that this was mainly due to a 'downward convergence of interest and inflation rates rather than deliberate action on the part of tax authorities'. However, in some areas, such as the introduction of special tax schemes to attract internationally mobile business, the report suggested that the degree of competition between countries was greater.

The tax-setting behaviour of governments can in some ways be described as co-operative - for example, through bilateral treaties or model conventions. However, there are also many ways in which governments compete both for mobile factors of production and for tax revenue - for example, through special incentives for inward investment. In addition, there continue to be international disputes over taxsetting behaviour, largely brought about by multinationals operating in several jurisdictions 1 .

This report examines what evidence there is in support of various models of tax competition using corporate income tax reforms in 10 countries Australia, Canada, France, Germany, Ireland, Italy, Japan, Spain, the UK and the US - over the period 1979 to 1994. A number of different measures of corporate income taxation are described. These measures reflect the rate at which income is taxed as

\footnotetext{
${ }^{1}$ For example, the case brought by Barclays Bank against the State of California against California's attempt at unitary taxation or the case brought by the German firm Hoechst against the UK imputation system.
} 
well as definitions of the tax base and other structural aspects of the tax systems considered. The measures presented include data on revenue collected from corporate income taxes, statutory tax rates, effective (marginal and average) tax rates and firm-level average tax rates.

This chapter considers some ways in which the international economy has changed, discusses how changes in the tax system can be measured and then describes the layout of the remainder of the report.

\subsection{Foreign Investment}

It is now a commonplace statement to say that the economy has become more global, but what is meant by this? In what ways has the economic environment changed and how do these changes affect the tax-setting behaviour of governments? Clearly, there are a large number of ways in which the world economy has changed since the late $1970 \mathrm{~s}$. We concentrate our attention on a few measures that theoretical models predict should affect the way and ability with which governments can collect tax on corporate income. These characteristics are largely to do with the size of the economy (in terms of output, number of employees or share of world trade), the openness of product markets (in terms of volume of imports and exports) and the mobility of capital_in terms of flows of foreign direct investment (FDI)). Ideally, we would like to measure

\footnotetext{
${ }^{2}$ In addition, there are many legal and institutional factors that are likely to have a large impact on governments' ability to tax capital (and investors' ability to avoid these taxes), which are beyond the scope of this report. These include the increasing globalisation of the services industry (for example, through the Internet) and the ability to shift profits around the globe at very low cost. The large increase in institutional ownership of shares has meant that the average investor is now far more sophisticated. Another factor is the relaxation of capital controls. For example, France
} 
Taxing profits in a changing world

restrictions on the movement of investment across international borders, and the FDI measures of crossborder flows can be thought of as indicators of this. It is important to emphasise that, in this report, we consider only direct investment (that is, investment made by one company into a foreign, usually majority-owned, subsidiary company) and not indirect investment (that is, portfolio investment made by a shareholder in a foreign company).

There is a debate in the academic literature over the extent to which capital markets can be considered to be integrated and what impact the globalisation of business has had on capital mobility. One of the most influential works in this area is Feldstein and Horioka (1980) which interpreted empirical evidence on the relationship between national savings and investment rates as suggesting that capital is relatively immobile internationally. Gordon and Bovenberg (1996) state that 'The evidence on international capital immobility is extensive, including the lack of international portfolio diversification, real interest differentials across countries and the high correlation between domestic savings and investment'. They argue that the most plausible explanation for the lack of capital mobility is that foreign investors do not have access to the same quantity or quality of information about investment opportunities as domestic investors. There are also alternative explanations for these observations. It is not possible to provide a full discussion of this debate here. This report aims to obtain an indicator of the ease with which a firm can choose between alternative locations

and Italy both prevented residents from shifting savings abroad until the mid-1980s. However, as this did not affect direct investment, it is not considered here.

${ }^{3}$ See Devereux (1996b) for a critique. 


\section{Introduction}

for an investment, an indicator which can be used in empirical work to approximate capital mobility.

A commonly quoted indicator of investment flows across borders is foreign direct investment. The 10 countries considered here accounted for around 81 per cent of outward and 84 per cent of inward world FDI flows over the 1980s. Figure 1.1 shows inward FDI flows into each of the 10 countries as a percentage of GDP. For most countries, this has increased over the period, though for many it fell back after the boom of the late 1980s. Spain, in particular, experienced very rapid growth up until 1991. Canada had a negative inflow of FDI (representing a net repatriation of foreign investment into Canada) in 1985. Figure 1.2 shows outward FDI flows from each of the 10 countries as a percentage of GDP. There is less of an increase in outward FDI/GDP over the whole period, although there was a very rapid increase in the late 1980s. Australia

FIGURE 1.1

Inward FDI flow/GDP

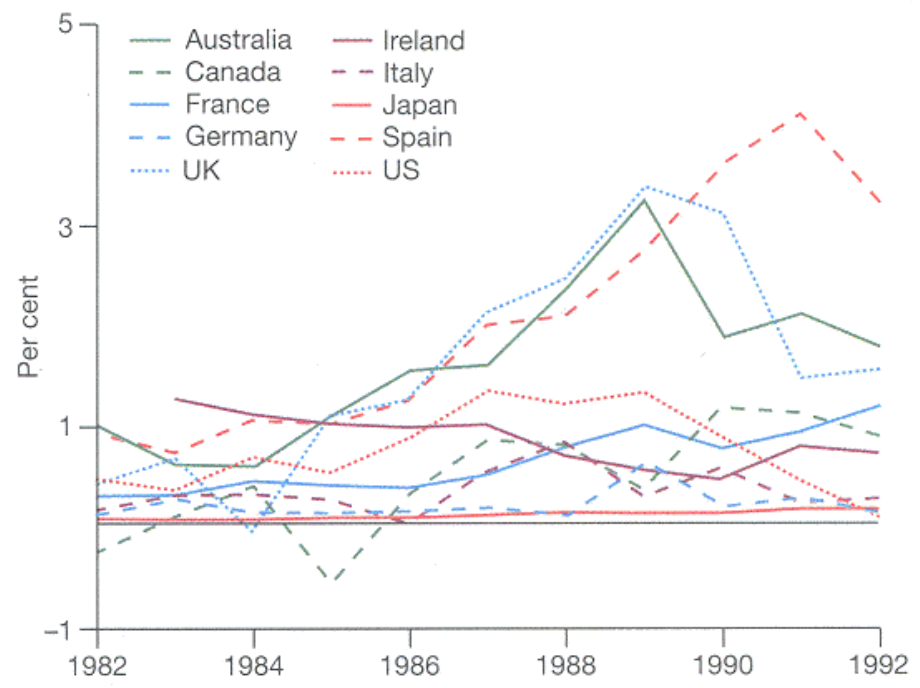

Source: OECD FDI Statistics database. 
Taxing profits in a changing world

FIGURE 1.2

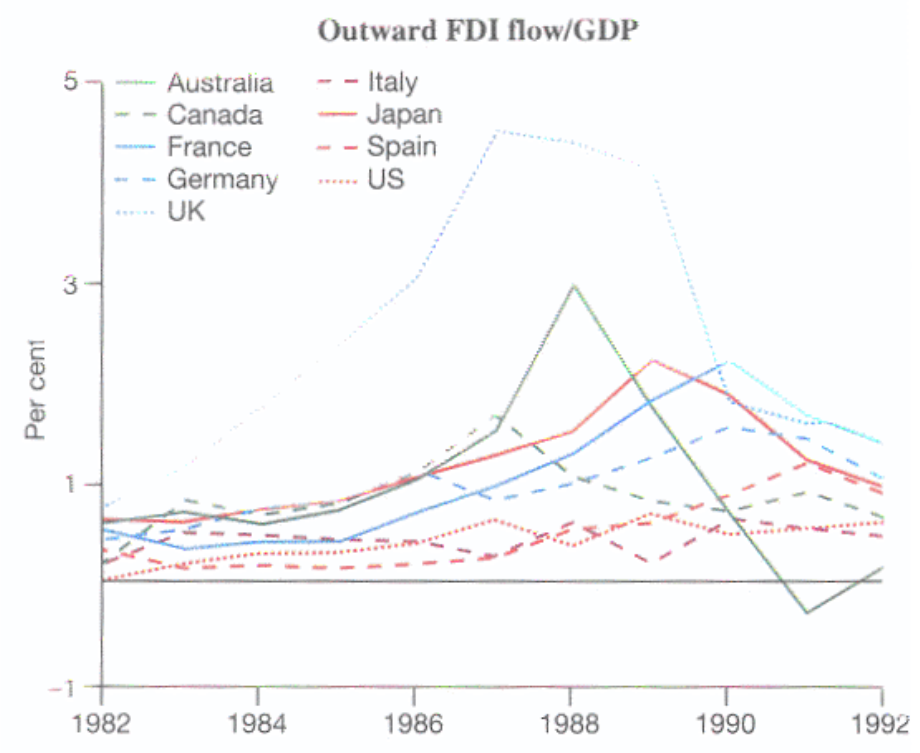

Source: OECD FDI Statistics database.

had a negative outflow of FDI (representing net repatriation of foreign investments from Australia) in 1991.

There are many problems associated with using FDI flow data to compare capital mobility across countries or over time. As with domestic investment series, flows of FDI are volatile and vary with the economic cycle, among other things. This means that the choice of comparison years will affect the growth rate calculated. It also makes comparisons across countries difficult where the economic cycles are not in step. Therefore, in Table 1.1, growth rates are presented for two time periods - 1983-89, which corresponds in most countries to the period of highest growth, and 1983-92. These growth rates are, on the whole, very high. The first column shows the growth rate in inward FDI flows as a proportion of GDP from 1983 to 1989. In most 


\section{Introduction}

TABLE 1.1

Growth rates

\begin{tabular}{l|rr|rr}
\hline & \multicolumn{2}{|c|}{ Growth in inward FDI/GDP } & \multicolumn{2}{c}{ Growth in outward FDI/GDP } \\
& $1983-89$ & $1983-92$ & $1983-89$ & $1983-92$ \\
\hline Australia & $4.48 \%$ & $1.99 \%$ & $1.52 \%$ & $-0.74 \%$ \\
Canada & $3.96 \%$ & $10.71 \%$ & $0.01 \%$ & $-0.21 \%$ \\
France & $2.19 \%$ & $2.88 \%$ & $4.35 \%$ & $3.05 \%$ \\
Germany & $1.30 \%$ & $-0.52 \%$ & $1.29 \%$ & $0.88 \%$ \\
Ireland & $-0.57 \%$ & $-0.42 \%$ & & \\
Italy & $0.02 \%$ & $-0.09 \%$ & $-0.55 \%$ & $-0.04 \%$ \\
Japan & $0.77 \%$ & $1.17 \%$ & $3.18 \%$ & $0.82 \%$ \\
Spain & $2.93 \%$ & $3.60 \%$ & $3.07 \%$ & $5.05 \%$ \\
UK & $3.98 \%$ & $1.28 \%$ & $2.63 \%$ & $0.48 \%$ \\
US & $2.91 \%$ & $-0.83 \%$ & $2.66 \%$ & $2.17 \%$ \\
\hline
\end{tabular}

Source: Authors' own calculations from OECD FDI Statistics database.

countries, FDI grew faster than GDP, and in several substantially faster. The growth rates in outward FDI/GDP shown in the final two columns show a different pattern and are not quite as high for most countries.

One of the main difficulties in using FDI flows to compare across countries arises from differences in the definition of FDI. For example, whether investment financed by retained earnings or local borrowing by the subsidiary is included in the definition of FDI varies both across countries and over time. Table 1.2 describes how each of the 10 countries treats profits made by subsidiaries of foreign parents that are not remitted to the parent. These can either be retained in the subsidiary or reinvested. In about half the countries, they are included as an FDI flow, while in the other half they are not. The importance of this is highlighted by Table 1.3, which shows that the single largest source of finance for US companies investing abroad in 1989 was local debt, and that 80 per cent of this outward US investment did not constitute an actual flow of capital from the US to 
Taxing profits in a changing world

TABLE 1.2

Treatment of retained profits in definition of FDI

\begin{tabular}{|c|c|}
\hline Australia & $\begin{array}{l}\text { Reinvested earnings by subsidiaries are included in inward and } \\
\text { outward flows. The threshold for ownership of FDI was changed in } \\
1985-86 \text { from } 25 \% \text { to } 10 \% \text {. }\end{array}$ \\
\hline \multirow[t]{3}{*}{ Canada } & Retained earnings of incorporated subsidiaries are not included. \\
\hline & From the first quarter of 1994 , reinvested earnings are included. \\
\hline & From 1983, equity investment in banks is included in outward flows. \\
\hline France & Reinvested earnings of subsidiaries are not included. \\
\hline Germany & Reinvested earnings of subsidiaries are included. \\
\hline Ireland & Statistics not available. \\
\hline Italy & Reinvested earnings of subsidiaries are not included. \\
\hline Japan & $\begin{array}{l}\text { Reinvested earnings of subsidiaries are not included, nor are interest } \\
\text { payments to direct investors. }\end{array}$ \\
\hline Spain & Not clear whether included or not. \\
\hline UK & The parent company's share of unremitted profits is included. \\
\hline US & The parent company's share of reinvested profits is included. \\
\hline
\end{tabular}

Note: Retained earnings are profits that are kept in the subsidiary and not repatriated to the parent company. Reinvested earnings are retained earnings that are reinvested by the subsidiary.

Source: OECD FDI Statistics database.

TABLE 1.3

US multinationals' sources of finance

\begin{tabular}{lr}
\hline Equity from US parent & $16.4 \%$ \\
Debt from US parent & $3.8 \%$ \\
Parent share of retained earnings & $18.3 \%$ \\
Local equity & $7.4 \%$ \\
Local debt & $45.8 \%$ \\
Local share of retained earnings & $8.2 \%$ \\
\hline
\end{tabular}

Source: 1989 Benchmark Survey of US Investment Abroad, US Department of Commerce, 1992. Parent and local share of retained earnings are attributed by the proportion of shares of the subsidiary each own.

the foreign country (this is shown by adding the parent's share of retained earnings to all local forms of finance).

Where a subsidiary of a foreign company borrows from a local bank and invests locally, this does not constitute a flow of capital across borders. Investment financed in this way could, however, be related to flows of intangible assets (such as management skills or know-how) across borders. 


\section{Introduction}

FIGURE 1.3

Long-term real interest rates

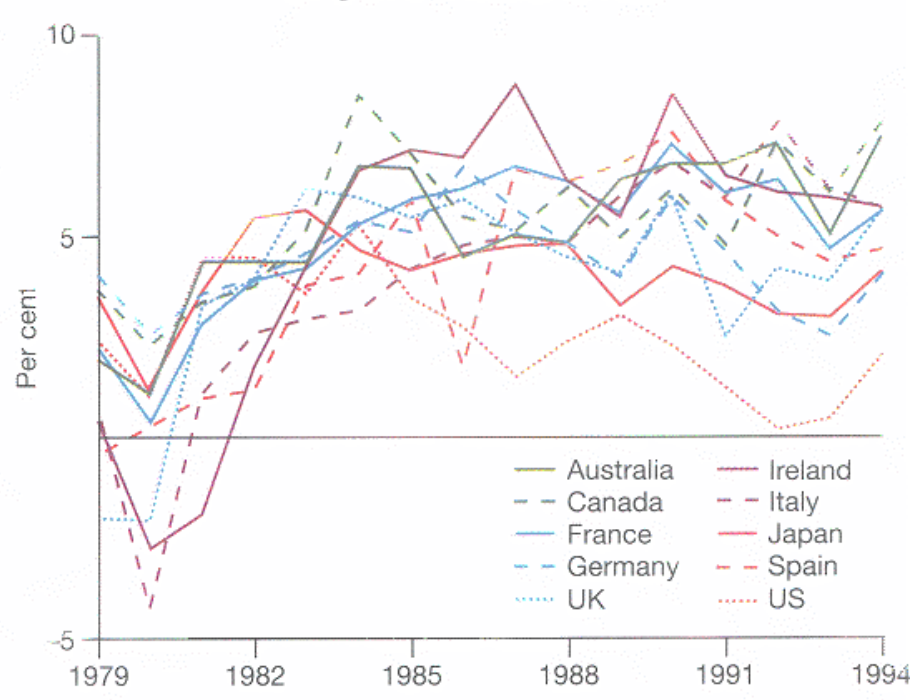

Source: Authors' calculations from OECD Economic Outlook data.

Another indicator of the integration of capital markets is the degree to which interest rates have converged or become more synchronised over time. Figure 1.3 shows the long-term real interest rates of the 10 countries considered in this report. There is some evidence to suggest that interest rate movements have become synchronised. In addition, there is also evidence to suggest that real interest rate differentials persist, and related work has shown that individuals' investment portfolios remain dominated by domestic stocks.

These various indicators suggest an increase in the globalisation of investment over the 1980s and early 1990s. The world's large economies appear to be more

${ }^{4}$ See, for example, OECD (1996).

${ }^{5}$ See Gordon and Bovenberg (1996) for a discussion of this work. 
Taxing profits in a changing world

integrated than they were in the late 1970s. The questions addressed in this report are whether this increasing internationalisation has coincided with a convergence of tax rates, and whether there is any evidence to suggest that governments have been using corporate income tax rates as an instrument of tax competition. The next section briefly discusses the measures that are used to examine these questions. The calculation and interpretation of these measures is described in more detail in later chapters, and also in Appendix A.

\subsection{Tax Measures}

Five measures of tax are used to consider how increasing internationalisation has affected the taxsetting behaviour of governments. These measures are (i) the statutory tax rate, (ii) corporate income tax revenues, (iii) the effective marginal tax rate, (iv) the effective average tax rate and ( $\mathrm{v}$ ) an average tax rate constructed using firm-level accounting data. The different measures can be informative about a range of issues such as incentives to invest, the behaviour of policymakers and the revenue implications of policy changes. For example, effective tax rates have been used to examine whether tax systems have become more neutral with respect to the incentives given to firms to invest in different assets, to use different forms of finance or to choose between alternative locations of production. Most commonly, they have been used to examine the question of the impact taxes have on various types of economic behaviour (for example, investment or production). The focus of this report is on their evolution over time and their potential for informing us about the tax-setting behaviour of governments. 
Reforms to the corporate income tax systems in the countries covered by this report are discussed in the next chapter. This includes a discussion of changes to the statutory tax rate, which is usually the most visible aspect of a tax reform, and the definition of the tax base, which can be equally important but can often receive less attention. The development of corporate income tax receipts over time is then considered in Chapter 3, using data collected by the OECD on corporate income tax revenue, for each of the individual countries over time. The figures are presented both as a proportion of total tax revenue, to demonstrate the relative importance of corporate income tax revenue to total government tax revenue, and as a proportion of GDP, to demonstrate whether the share of national income collected in corporate income taxes has remained stable over time.

The bulk of the report concentrates on evaluating both marginal and average effective tax rates. Effective tax rates take into account not only the statutory corporate income tax rate, but also other aspects of the tax system that are likely to affect the amount of tax paid and the profitability of an investment, such as the level of capital allowances and the method by which personal and corporate income taxes are integrated (if at all). It is possible to calculate effective tax rates for different types of investment projects, which are financed by different methods and carried out either by domestic firms or by firms based in a different country from the location of the project itself. The alternative combinations are almost endless, which makes it necessary to limit the number of rates calculated; however, this report aims to present a range of measures on a consistent basis over time and across countries.

The first effective tax rate presented is the effective marginal tax rate (EMTR). This is the effective rate of tax that applies to a marginal investment project. A 


\section{Taxing profits in a changing world}

marginal investment earns a rate of return after tax that is just sufficient to persuade investors to make the initial outlay. This rate of return is known as the required rate of return, since it is the minimum return that investors are prepared to receive. If an investment does not earn this minimum, investors could do better by putting their capital into a safe alternative, such as a government bond, and would do so rather than invest in the project.

The effective marginal tax rate measures the difference between the pre-tax rate of return earned by the company on that marginal investment project and the post-tax rate of return earned by the investor, expressing this difference (known as the tax wedge) as a proportion of the investor's post-tax return. It can be thought of as the proportional difference between the remuneration to capital from production and the actual compensation received by the owners of the firm. EMTRs can be calculated for a domestic investment or for international investment, where the source of finance for the project (i.e. the parent company) is not based in the same country as the location of the investment. This report presents EMTRs both for domestic investments, which gives a picture of how individual countries' tax systems have changed over time, and for direct international investments, both into and out of the countries in the study, which allows comparisons to be made across countries.

The second effective tax rate presented is the effective average tax rate (EATR). This is the effective rate of tax that applies to an investment project that earns some economic rent, i.e. a project that earns more than the minimum required after-tax rate of return. The EATR is the difference in the present value of the investment project in the absence and in the presence of tax, as a proportion of the present value of the project in the absence of tax. The figures presented assume that 
the investment earns a real return of 40 per cent in the absence of tax.

EATRs are the relevant measure of tax for considering the choice between alternative large investment projects. The choice of which project is carried out will depend upon where the highest post-tax profits can be earned. If the project is expected to earn economic rent, then the tax rate on those expected rents will be an influential factor in the decision over where to carry out the investment. As with the EMTRs, average tax rates are calculated both for purely domestic investments and for direct investment made abroad.

Finally, a measure of the average tax rate (ATR) constructed from firm-level accounting data is considered. Using information from multinational companies' accounts, an average tax rate is calculated for each firm based on the ratio of the provision made for tax to the net pre-tax income. The mean value of these individual firm tax rates is presented. These average tax rates reflect complexities of the tax system that are not captured by the stylised effective tax rates, such as the fact that some firms cannot always make use of all their allowances against tax (a situation known as tax exhaustion). They are not directly comparable with the EATRs for several reasons. The accounting measure will be based on the actual source of finance and asset structure of individual firms, which will vary over time and across countries. The EATR, on the other hand, is calculated assuming fixed finance and asset structures. The accounting data will also reflect the full range of the investments carried out by individual companies over many years, while the EATR applies to an investment made in the current year. Individual company investments will have a range of profitability levels, while the EATR is calculated for a fixed level of profitability. 


\section{Taxing profits in a changing world}

One important caveat to bear in mind when interpreting these tax rate measures is that, although they indicate what taxes are levied on corporate income, this does not necessarily mean that the final incidence of these taxes falls on the owners of capital. Determining the final incidence of corporate income taxes - in other words, those individuals ultimately made worse off by the existence of the tax - is a complex matter. If the incidence of a tax falls on capital, this means that the cost of the tax has been borne by the owners of the company, in the form of a lower return on their investment. However, the cost of the tax could also be passed on to consumers in the form of higher prices, or to employees in the form of lower wages. Where the final burden actually falls will depend upon the nature of the markets in which the company operates.

Another important caveat to the analysis presented here is that the tax system is not the only fiscal instrument for governments to use to alter the incentives for investment, and therefore is not the only relevant measure of competition between governments. Direct subsidies to investment can also be significant and can act as substitutes for concessions within the tax structure ${ }^{6}$

Finally, there are aspects of the calculation of effective tax rates that should be noted, including the fact that one underlying assumption is that firms undertake their investment with the expectation that the current tax treatment is not going to change in the future. It is also the case that, in order to make the

\footnotetext{
${ }^{6}$ Approximately US\$54 billion was spent on industrial support across the OECD in 1,552 projects in 1992. OECD (1996) reports that 'Only 4.1\% of all support programmes reported limit public support to national enterprises. The opening of support policies to domestically established, foreign-owned firms or to enterprises from abroad, can be considered a policy response to world-wide industrial globalisation'.
} 


\section{Introduction}

results manageable, certain assumptions have to be made about what sort of investment should be considered, how that investment is financed and, in the case of international effective tax rates, the complexity of the arrangements for financing the foreign direct investment. As a result, these tax rates cannot capture every aspect of a country's tax system, but should capture the most important elements in a way that is consistent over time and between countries.

\subsection{Structure of the Report}

The layout of the report is as follows. Chapter 2 describes the major reforms that have taken place in the 10 countries considered. Chapter 3 looks at how tax revenues in these same countries have evolved. In Chapter 4, effective tax rates on domestic and international investment are presented and the extent to which they have converged over time and across sources of finance and type of asset is discussed. Chapter 4 also presents an alternative measure of the average tax rate using firm-level accounting data. The questions of whether capital import and capital export neutrality hold and the degree to which tax rates have converged over countries are examined. Chapter 5 discusses theoretical models of tax-setting behaviour and considers whether the data described in the previous chapters can help distinguish between the various models. A final chapter summarises the report and lays out some areas of future research. Appendix A describes the methodology used in collecting the data and constructing the tax measures. Appendices B-L describe the tax systems in each of the 10 countries in more detail. 


\section{CHAPTER 2 \\ Tax Reforms}

This chapter summarises the main reforms to the corporate income tax systems of the countries covered by this report. The aspects of the tax system described are those that apply to a large manufacturing firm undertaking an investment in fixed capital and that are generally available. This excludes, for example, special incentive schemes or grants. Both domestic and international investments are considered. The precise definitions of the variables are given in Appendix A and details of each tax system are given in Appendices B-L.

The dominant trend in tax reform over the period 1979-94 has been towards a lowering of tax rates, combined with extending the tax base through a reduction in the value of allowances given for investment. This trend has been seen in Canada, France, Ireland and, most notably, the UK and the US. However, this has not been the only type of reform: some countries have raised their tax rates; other countries, such as Germany, have both lowered their tax rates and increased the generosity of depreciation allowances (i.e. combined a lower tax rate with a narrower tax base).

Table 2.1 summarises the main reforms to the corporate income tax system in each country. Figure 2.1 shows the statutory tax rate that applies to earnings retained by the company (not, for example, distributed in the form of dividend payments). This rate includes any surcharges or additional taxes that are levied on corporate income at the national level, as well as local corporate income taxes (see Appendix A for a more precise definition). Statutory tax rates have declined in 
seven countries and risen in two (Italy and Spain). The highest statutory rates at the end of the period are found in Germany, Italy and Japan at around 52 per cent. Australia, Canada, France, Spain and the UK converge to a statutory rate around 33 per cent, with the US falling near the middle, at just over 39 per cent. The unweighted average statutory tax rate on retained earnings (shown in Figure 2.1), excluding Ireland, has fallen from around 48 per cent to just over 40 per cent. Several countries operate a split-rate system where there are two statutory tax rates, one applying to profits that the company retains and another for the profits that it distributes to shareholders (for example, in the form of a dividend payment). The statutory tax rate on distributed earnings (shown in the individual country appendices but not shown here) follows a similar pattern except that the average is lower, falling from 43 per cent in 1979 to 37 per cent in 1994 (excluding Ireland).

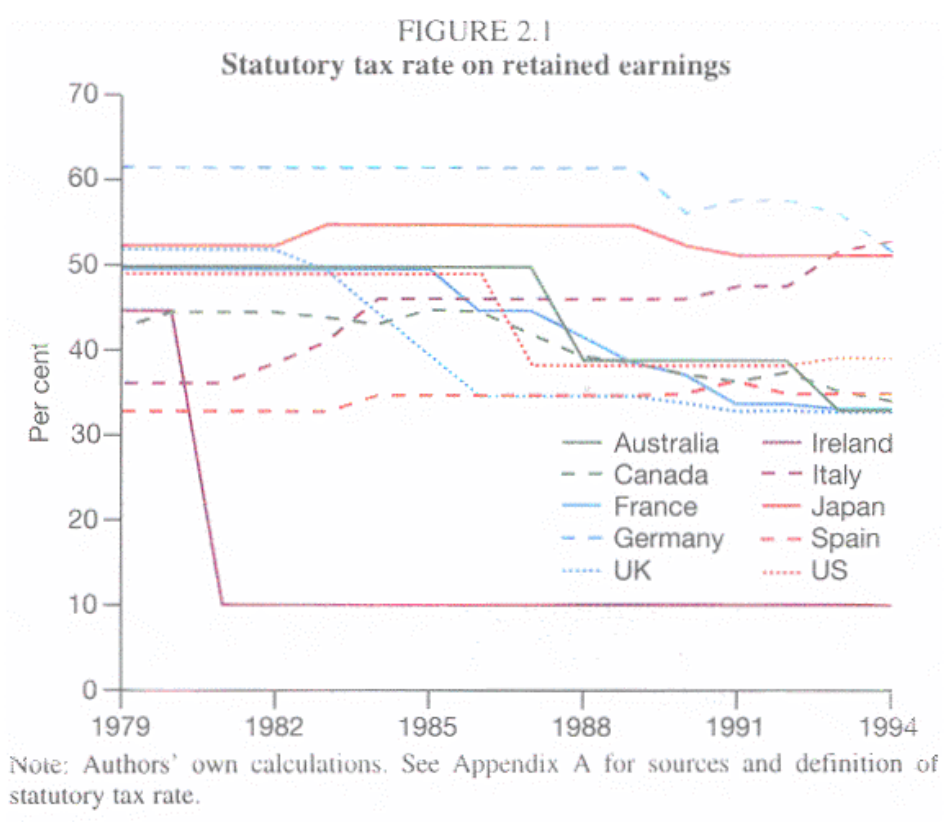




\section{Taxing profits in a changing world}

TABLE 2.1

Summary of corporation tax reforms 1979-94

\begin{tabular}{|c|c|}
\hline Australia & $\begin{array}{l}\text { Prior to } 1988 \text {, a split-rate system was in operation. The statutory rate } \\
\text { on distributed profits was } 46 \% \text { in } 1979 \text {, rising to } 49 \% \text { in } 1986 \text {. The } \\
\text { reform in } 1988 \text { introduced an imputation system and reduced the } \\
\text { statutory rate from } 50 \% \text { to } 39 \% \text {. This was further reduced to } 33 \% \text { in } \\
\text { 1993. Depreciation rates have fluctuated but remained high relative } \\
\text { to the other countries considered. }\end{array}$ \\
\hline Canada & $\begin{array}{l}\text { The statutory tax rate has fallen by } 10 \text { percentage points in a series of } \\
\text { reforms, the largest one being a } 7 \text { percentage point reduction in the } \\
\text { basic federal statutory rate in } 1988 \text {. Several reforms have reduced the } \\
\text { value of depreciation allowances, notably when the 'special two-year } \\
\text { write-off' for plant and machinery was changed in } 1983 \text { to a 'special } \\
\text { three-year write-off' and then abolished in } 1987 \text {. In 1989, the general } \\
\text { Investment Tax Credit of } 7 \% \text { was abolished. The withholding tax } \\
\text { rate on dividends and interest repatriation to most countries has fallen } \\
\text { in various years. }\end{array}$ \\
\hline France & $\begin{array}{l}\text { The statutory tax rate fell from } 50 \% \text { to } 33 \% \text { in several reforms. } \\
\text { Depreciation allowances have not changed significantly except for an } \\
\text { initial investment allowance which was given from } 1981 \text { to } 1985 \text {. } \\
\text { From } 1986 \text {, new equity was given more generous treatment. } \\
\text { Withholding taxes on cross-border dividend and interest payments to } \\
\text { several countries have come down. }\end{array}$ \\
\hline Germany & $\begin{array}{l}\text { The statutory tax rates on retained earnings and on distributed profits } \\
\text { (Germany operates a split-rate system) have fallen, although they } \\
\text { rose in } 1991 \text { due to the imposition of a 'Solidarity' Surcharge of } \\
3.75 \% \text {. Depreciation allowances have become more generous, } \\
\text { especially on industrial buildings. Withholding taxes on the } \\
\text { repatriation of dividends to many countries have reduced } \\
\text { significantly. }\end{array}$ \\
\hline Ireland & The statutory tax rate fell from $45 \%$ to $10 \%$ on manufacturing firms. \\
\hline Italy & $\begin{array}{l}\text { The statutory tax rate has risen substantially in a series of reforms, } \\
\text { from increases in the headline rate in } 1983 \text { and changes to } \\
\text { deductibility rules for local corporate tax. Depreciation allowances } \\
\text { reduced in } 1988 \text { and } 1990 .\end{array}$ \\
\hline Japan & $\begin{array}{l}\text { The statutory tax rate has increased slightly on retained earnings } \\
\text { (with a larger increase in the late 1980s) and substantially on } \\
\text { dividends (due to the abolition of a split-rate system in 1991). }\end{array}$ \\
\hline Spain & $\begin{array}{l}\text { The statutory tax rate was increased from } 33 \% \text { to } 35 \% \text { in } 1984 \text { (in } \\
1991 \text {, a } 1.5 \% \text { surcharge was imposed by local Chambers of } \\
\text { Commerce). There have been few substantial reforms besides this. }\end{array}$ \\
\hline UK & $\begin{array}{l}\text { The statutory tax rate has fallen substantially in a series of reforms, } \\
\text { lowering it by } 15 \text { percentage points between } 1983 \text { and } 1986 \text {. At the } \\
\text { same time, depreciation allowances became significantly less } \\
\text { generous. The imputation rate has fallen (along with the lower/basic } \\
\text { rate of personal income tax). }\end{array}$ \\
\hline US & $\begin{array}{l}\text { There have been two major tax reforms in the US, in } 1981 \text { and } 1986 \text {. } \\
\text { The } 1981 \text { reform increased the generosity of depreciation } \\
\text { allowances. The } 1986 \text { reform reduced the statutory tax rate from } 46 \% \\
\text { to } 34 \% \text { and made depreciation allowances, particularly on industrial } \\
\text { buildings, less generous. }\end{array}$ \\
\hline
\end{tabular}


As an example of how the tax base has changed, Figure 2.2 shows how allowances for plant and machinery have declined over time. It depicts the net present value (NPV) of the allowance given on an

FIGURE 2.2

NPV of depreciation allowances for plant and machinery

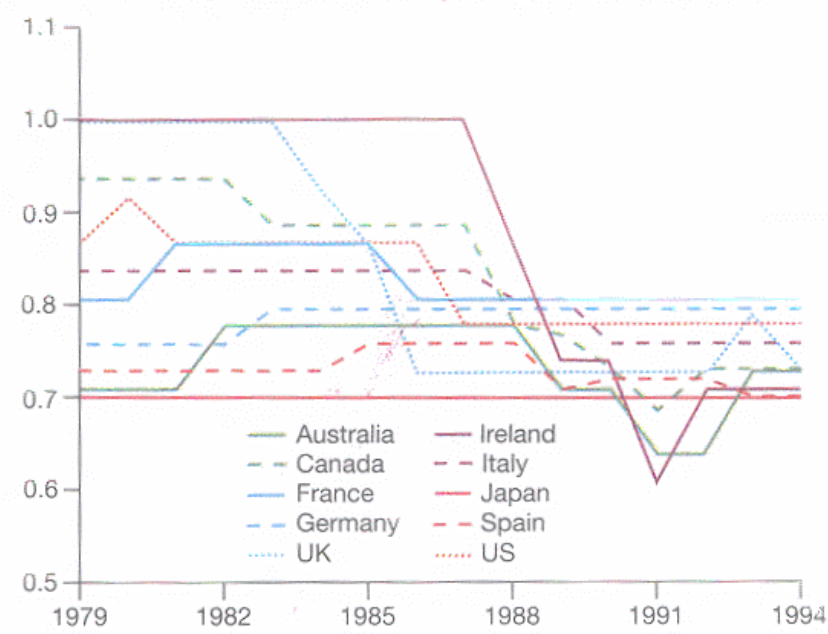

Note: Authors' own calculations. See Appendix A for sources and definitions of depreciation allowances.

investment in plant and machinery for industrial use. $\mathrm{A}$ value of unity indicates that the investment is fully deductible in the first year, while a value of zero would indicate that no deduction is given for expenditure on capital equipment. This graph therefore gives an impression of the degree to which the tax base has broadened over time in the countries studied here.

In addition to changes in domestic tax policy, there have been changes to international aspects of the taxation of corporate income. ${ }^{8}$ Bilateral treaties between

\footnotetext{
${ }^{7}$ A more detailed definition is given in Appendix A.

${ }^{8}$ There have been some fairly significant changes in the international treatment of groups of related companies, such as the recent legislation on
} 


\section{Taxing profits in a changing world}

countries form the basis of most aspects of international agreements on tax arrangements, including the level of withholding tax rates and the reciprocity of tax credits, as well as many other aspects of taxation. Treaties do not tend to be renegotiated frequently, and amongst the countries considered here, most had negotiated treaties prior to 1979. Withholding taxes levied by countries in which an investment is located (source countries) upon the repatriation of income from that investment to the residence of the owner (residence countries) have fallen in general. This is not uniformly true, however, and they remain greater than zero in many countries. In 1979, the mean of withholding tax rates on repatriated dividend income across all 10 countries was just under 10 per cent; by 1994, it had fallen to 6.6 per cent. Similarly, in 1979 , the weighted mean of withholding tax rates on cross-border interest payments was just over 10 per cent; by 1994, it had fallen to 8 per cent.

controlled foreign corporations and rules for setting transfer prices (the prices a company charges on inter-firm sales). Incorporating these changes into the general framework used here is beyond the scope of this report.

${ }^{9}$ Weighted by the outward flows of FDI shown in Table A.2 in Appendix A. 


\section{CHAPTER 3 \\ Tax Revenue}

In the previous chapter, we saw that there was a general (though not universal) tendency towards rate-reducing and base-broadening reforms of corporate income tax. What impact have these reforms had on tax revenues? In general, a reduction in the statutory tax rate will tend to reduce revenue while a widening of the base will tend to increase it. The overall impact of rate-reducing and base-broadening reforms can therefore be to increase revenue, reduce it or leave it at the same level as previously (i.e. a revenue-neutral package of reforms). In addition, taxpayers might change their behaviour in response to such reforms. For example, if a reform extended the tax base to include an activity not previously taxed, companies undertaking that activity might decide not to do it, or to do it somewhere where it was not taxed (or was taxed at a lower rate). This chapter looks at what has happened to revenue over the same time period and discusses some of the other factors that affect corporate income tax revenues and some of the difficulties involved in interpreting these statistics.

Figure 3.1 shows the total amount of revenue collected from 'taxes on corporate income' as a percentage of GDP. 10 The heavy black line represents the average across all OECD countries (where each country has been weighted by its GDP), which has remained remarkably constant at around 3 per cent.

\footnotetext{
${ }^{10}$ See the end of this chapter and Appendix A for a discussion of problems with the comparability of these data across countries.
} 
Taxing profits in a changing world

Figure 3.1, however, also shows that different countries have experienced quite different patterns of corporate income tax receipts. The continental European

FIGURE 3.1

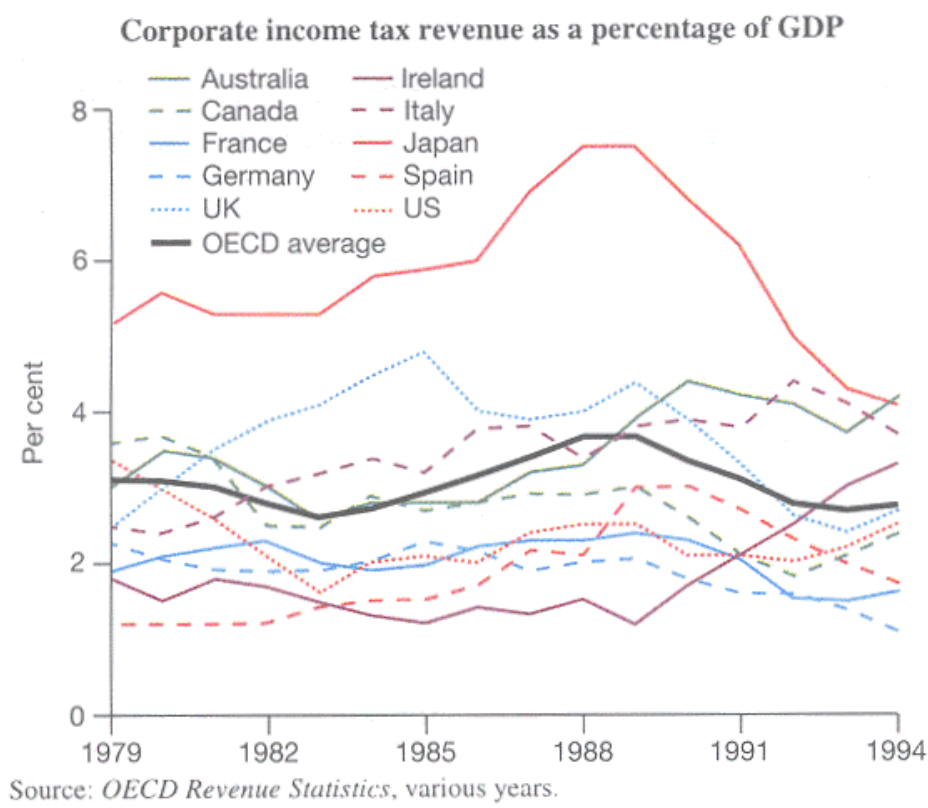

countries have collected a relatively constant amount of revenue from corporate income tax as a percentage of GDP, although both Germany and Spain have experienced a recent decline. In the UK, revenue has fluctuated between 2.5 per cent and almost 5 per cent of GDP, while Ireland, Italy and Spain have all experienced an increase. Ireland in particular is interesting. Despite its low statutory tax rate (albeit only on manufacturing), it still collects about the same proportion of corporate income tax as a share of GDP as that collected in other European countries, particularly since 1990. The US, Canada and, to a lesser extent, France have all seen a decline in the share of GDP taken in corporation tax receipts, although the US seems to 
have stabilised since the 1986 reforms. The amount of revenue from corporate income tax receipts in Japan increased dramatically to almost 8 per cent during the late 1980 s, but has now fallen back to around 5 per cent. Australia also now collects far more revenue from corporate income tax than previously, reaching a similar level to Japan by the early 1990 s.

\section{FIGURE 3.2}

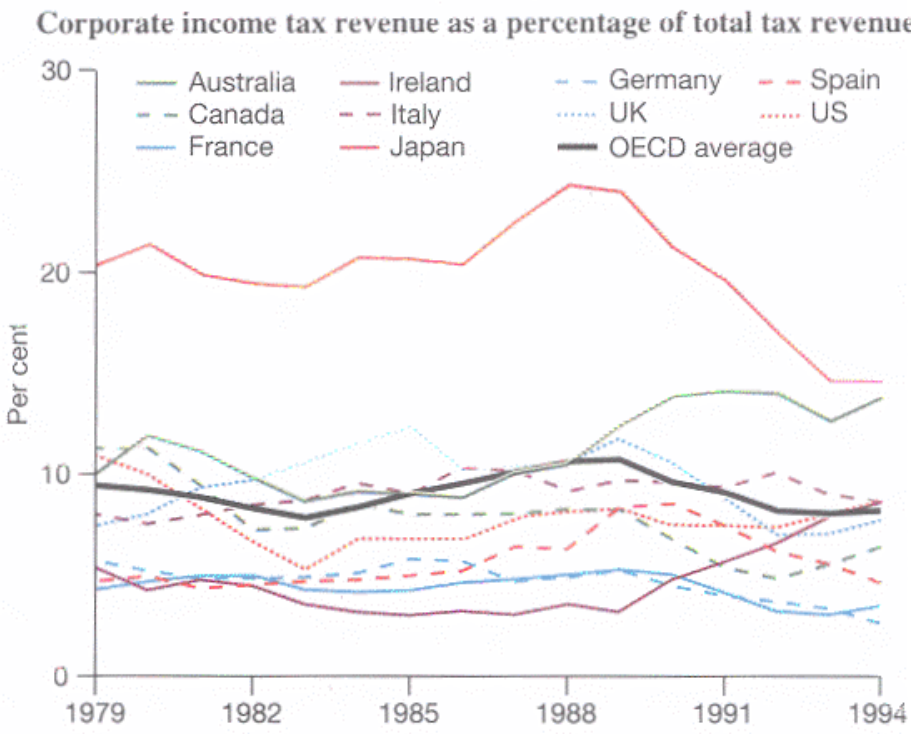

Source: $O E C D$ Revenue Statistics, various years.

Figure 3.2 shows the percentage of total tax revenue that comes from corporate income tax. We see very similar trends across countries to those shown in Figure 3.1. Tax revenue collected from the three other main sources of government revenue - taxes on personal income, social security contributions and goods and services taxes - have all increased as a proportion of GDP over the period. Total tax revenue as a proportion of GDP has risen from around 34 per cent in 1979 to 38 per cent in 1994 for the OECD as a whole. 


\section{Taxing profits in a changing world}

Discussions of how tax reforms affected each country's revenue are given in the individual country appendices. However, these figures do appear to indicate that rate-lowering, base-broadening reforms of corporate income tax, taken in conjunction with other influences on the economy, have not had a dramatic impact on the amount of revenue collected as a proportion of GDP. It is important to note that the tax system described in the rest of this report applies specifically to the manufacturing sector (although the statutory tax rate, for example, usually applies to the whole corporate sector). The role of the manufacturing sector has been in decline in most countries over this period, so the tax rates calculated here apply to a diminishing proportion of economic activity. None the less, these revenue figures indicate that the overall impact of corporate income tax reform has been relatively neutral with respect to revenue.

One difficulty in analysing these data is that the definition of what constitutes a corporate income tax, as opposed to a personal income or consumption tax, is not consistent across countries, particularly where only some countries have a degree of integration of their corporate and personal income taxes (see Appendix B for details). In addition, corporate income tax revenues are influenced by a number of factors other than the tax rate and definition of the tax base. Both current and past levels of profitability in the corporate sector affect tax liabilities and tend to make corporate tax receipts cyclical. Differences in the delay between earning corporate income and paying tax on that income, and differences in the arrangements for dealing with losses, mean that receipts will follow the economic cycle more or less closely in different countries. Another factor affecting the amount of revenue classified as corporate, rather than personal, income is the balance within the 
economy of investment in the incorporated and unincorporated business sectors, which may vary over time and across countries. For example, an increasing proportion of revenue is derived from areas of the economy such as the financial services and commercial sectors, because these have been growing in importance over time in most major economies. 


\section{CHAPTER 4 Effective Tax Rates}

Effective tax rates are a useful tool for summarising the impact of the tax system on the required rate of return, i.e. the minimum rate of return that an investor must earn in order to make a particular investment project worth undertaking. They measure the tax rate that applies to a small increase in the level of real investment carried out by the corporate sector, which is financed by an increase in domestic household saving in the country of residence of the shareholder. They take into account differences in definitions of the tax base as well as differences in tax rates. They reflect differences in capital allowances, the degree of integration of the corporate and personal tax systems, the treatment of capital gains and inventories, levels of withholding taxes and other aspects of international tax treaties. Differences in other factors that affect profitability, such as inflation and exchange rates, can also be reflected in effective tax rates.

They are, therefore, a useful way of comparing the impact of various tax reforms across countries and over time, isolating the impact of tax from other factors that may also be changing. In this chapter, we consider two types of effective tax rates - the effective marginal tax rate and the effective average tax rate. The marginal rate is the effective rate of tax that applies to a marginal investment project, i.e. one that just earns the minimum required rate of return after tax. The average rate is the effective rate of tax that applies to an investment project earning some economic rent, i.e. earning more than the minimum required after-tax rate of return. 
The effective marginal tax rate (EMTR) summarises the impact that taxes have on the cost of making a marginal investment. The real pre-tax rate of return to the company, known as $p$, is assumed to be 10 per cent for all investment projects, and information about the specific details of individual countries' tax systems is used to find the post-tax rate of return to the saver (usually denoted by $s$ ). The difference between the preand post-tax returns $(p-s)$ is the effective marginal tax wedge, which measures the absolute difference in the return on an investment introduced by the operation of the tax system. The EMTR is this tax wedge expressed as a proportion of the post-tax return to the saver, $s$. This is the 'tax-exclusive' EMTR, since it scales the tax wedge by the post- rather than pre-tax return, and it measures the relative difference between the pre- and post-tax rates of return for a marginal investment.

The EMTR provides information on the impact of tax on different types of investment projects, according to the type of physical investment being carried out and according to the type of financing method used to pay for the investment. It is also possible to allow for the tax position of the investor to vary, although this study concentrates on effective tax rates for the tax-exempt investor. These individual EMTRs provide a picture of the extent of the distortions introduced by the tax system between, for example, an investment in plant and machinery financed by debt and an investment in inventories financed by retained earnings. The former might have a significantly lower EMTR, due to the particulars of the operation of the tax system. An overall average EMTR can be constructed from the individual

\footnotetext{
${ }^{11}$ Calculations of effective tax wedges are given in the individual country appendices, while the detailed formulas used for all calculations are described in Appendix A.
} 


\section{Taxing profits in a changing world}

tax rates for different types of finance and asset, using appropriate weights. In addition, the analysis can be extended to cover cross-border investments, which allows the comparison of relative distortions of different types of investment in different countries.

In a traditional model of a perfectly competitive closed economy, the EMTR is informative about the impact of tax on the total level of investment. However, in a model with imperfect competition and capital mobility, the EMTR does not tell us everything about how taxes will affect the overall level of investment. This issue has recently been discussed in Devereux and Griffith (1997). An alternative rate to calculate is the effective average tax rate.

The effective average tax rate (EATR) summarises the impact of taxes on the cost of an investment project that earns some economic rent, i.e. a rate of return greater than the minimum required rate of return. It is measured by calculating the difference between the present value of a project that earns a pre-tax real rate of return of 40 per cent, if there were no taxes levied on the project (this present value is denoted by $V^{*}$ ), and the present value of the project if taxes were levied (denoted by $V$ ), using the details of the individual tax systems. This difference between the value of the project in the absence and in the presence of tax $\left(V^{*}-V\right)$ is expressed as a proportion of the value in the absence of tax, to give the effective average tax rate.

EATRs are the relevant measure of tax when considering the choice between several alternative investments, only one of which will be carried out by the firm. The choice of investment will depend on where the highest post-tax profits can be earned. If the

${ }^{12}$ This might be the case if there are barriers to entry to the new market or if the firm faces liquidity constraints. 
project is expected to earn economic rent, then the tax rate on those expected rents will be an influential factor in the decision over where to carry out the investment. Devereux and Griffith (1997) discuss when the EATR might be the most suitable measure to use and examine its empirical properties. As an example, consider a multinational firm that intends to set up a factory in a region and can choose between a small number of locations. It expects to earn an economic rent on its activity by exploiting an advantage that is specific to that firm, such as a patent. However, due to economies of scale in production, it will not build more than one factory. In this case, the location chosen will be the one with the highest post-tax profit; the impact of taxation in this case is therefore simply the proportion of total income taken in tax in each location. Since this is not a marginal investment, it is not measured by the EMTR. Instead, it is measured by the EATR, which is the proportional change in the net present value of the investment project brought about by tax.

Another example would be a firm choosing between a number of alternative means of production. Perhaps after a suitable amount of research and development (R\&D), the factory could become more automated, compared with a relatively labour-intensive production process if the R\&D were not carried out. Again, if the product is expected to earn an economic rent, then the EATR — and not the EMTR - is the appropriate means of investigating the impact of tax on the choice of whether or not to perform the R\&D.

A third possibility would be a firm that cannot raise suitable finance to fund its projects due to imperfections in financial markets. One effect of tax in this case would be to determine the availability of retained earnings, which again depends upon the proportion of profit or income taken in tax. However, being in a position where 


\section{Taxing profits in a changing world}

total investment is restricted again implies that the firm might have to choose between different investment projects, rather than carrying them all out. The impact of tax upon the choice of projects can be measured by the EATR.

For calculation of the effective tax rates, it is assumed that the investment projects are undertaken by a large manufacturing firm, in three types of asset industrial buildings, industrial plant and machinery, and inventories. For a domestic investment, three methods of financing it are considered - retained earnings, new equity and debt. For an international investment, it is assumed that the project is carried out by a foreign subsidiary, wholly-owned by a domestic parent company, and seven types of finance are considered the subsidiary uses retained earnings; the subsidiary raises new equity from the parent and the parent funds this from retained earnings, new equity or debt; the subsidiary raises debt from the parent and the parent funds this from retained earnings, new equity or debt. For more information on the methodology, see Appendix A, King and Fullerton (1984), OECD (1991) and Jorgenson and Landau (1993) among others.

The final type of tax rate presented in this report is an average tax rate (ATR) calculated using actual information from the published accounts of multinational companies. This tax rate is based on the ratio of the 'net provision for taxes' to 'net pre-tax income' registered in the accounts. It is a measure of the tax rate the firm faces, given its current activities and its past history of investment projects, rather than a forward-looking measure of the tax rate payable on a new investment project, which the effective tax rates attempt to capture. These firm-specific average tax rates also reflect complexities of the tax system that are not captured by the stylised effective tax rates, such as the 
fact that some firms cannot always make use of all their allowances against tax (a situation known as tax exhaustion). An average of the firm-specific average tax rates is presented here. There are limitations to the use of accounting-based tax rates to make comparisons between different countries, which are discussed in Appendix A.

\section{FIGURE 4.1}

Domestic effective marginal tax rates

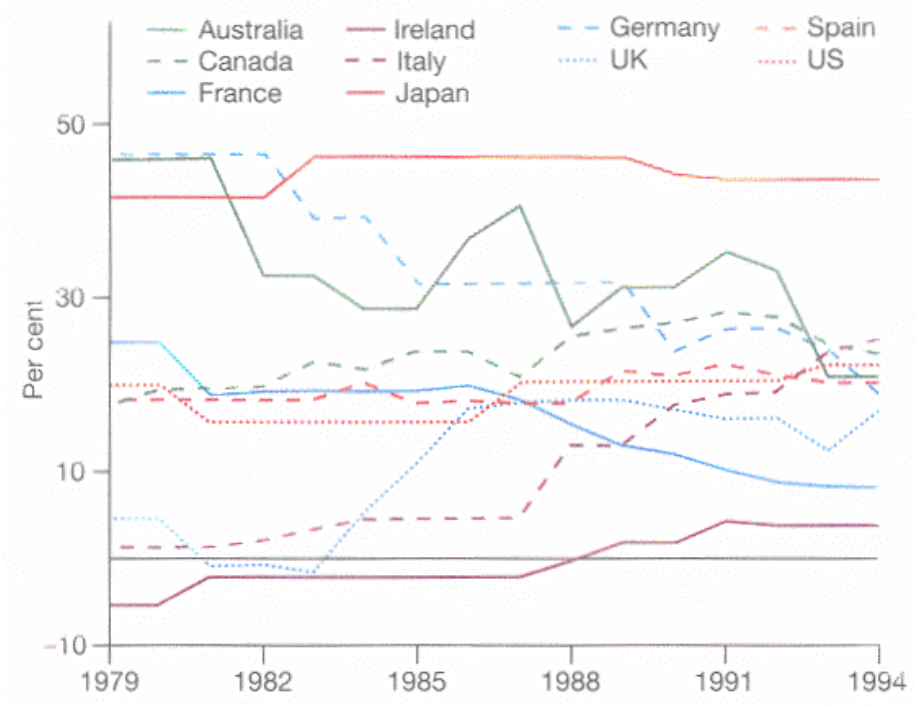

Note: Authors' own calculations. See Appendix A for sources and definition of EMTR. Weighted average across both finance and assets. Weights used are: $28 \%$ buildings, $50 \%$ plant and machinery, $22 \%$ inventories: $55 \%$ retained earnings, $10 \%$ new equity, $35 \%$ debt. Inflation is held constant at $3.5 \%$ and the real interest rate at $10 \%$. Economic depreciation rates are $3.61 \%$ for buildings, $12.25 \%$ for plant and machinery and $0 \%$ for inventories.

\subsection{Effective Tax Rates for Domestic Investment}

In this section, both marginal and average effective tax rates (ETRs) for a domestic investment are presented and discussed. The marginal investor is considered to be exempt from tax (for example, a pension fund) and thus the post-tax minimum required rate of return is the real 
Taxing profits in a changing world

interest rate. ${ }^{1.3}$ A constant inflation rate of 3.5 per cent and real interest rate of 10 per cent have been used in all countries in all years unless otherwise specified. Keeping inflation and interest rates constant allows us to focus on the impact of tax on the required rate of return. 14

The analysis presented in this section focuses on the comparison of the trends in ETRs across different countries, asset types and sources of finance. For a discussion of the impact of tax reforms on individual country ETRs, see the country appendices.

\section{Effective marginal tax rate}

Figure 4.1 shows the EMTR on a domestic investment. The direction and size of change in this measure have varied across countries. Japan has maintained a high EMTR throughout the period, while Germany has fallen from having the highest EMTR in 1979 to about average in 1994. Ireland, Italy and the UK have experienced notable increases, and Australia's EMTR has fluctuated substantially. The graph gives some indication that EMTRs have converged over time, particularly if Japan is excluded.

\section{Within-country variation}

Before examining the extent to which effective marginal tax rates have converged between countries, it is

\footnotetext{
${ }^{13}$ This assumption is perhaps more valid for the UK and the US, where pension funds hold a large proportion of equity, than for the other countries considered.

${ }^{14}$ This methodology does not formally account for the fact that some investment projects have uncertain outcomes. Under certain conditions, the rate of return can be interpreted as an expected rate of return, with a risk premium added to the real interest rate to obtain the minimum required rate of return.
} 
interesting to note whether they have converged within countries. Jorgenson and Landau (1993) compared effective tax rates across nine countries for the years 1980, 1985 and 1990, focusing on the extent to which the tax systems were neutral with respect to source of finance and type of asset. A similar analysis is undertaken here for all years between 1979 and 1994.

Table 4.1 shows the means and standard deviations of the effective marginal tax rate within each country in each year. 15 These are calculated across the nine combinations resulting from the three different types of asset and three different types of finance. The standard deviations, shown in italics, indicate the extent to which the tax system in each country has become more or less neutral with respect to the source of finance and type of asset invested in. The final column shows the overall average. The average standard deviation across the nine finance-asset pairs declines over time from 59.0 to 42.0, indicating that, on average, tax systems have become more neutral in these countries. In three countries Italy, Japan and Spain - this does not hold true: the standard deviation in these countries has remained stable or increased over time, indicating that these tax systems are less neutral at the end of the period than they were at the beginning.

\footnotetext{
${ }^{15} \mathrm{An}$ alternative measure is the coefficient of variation (the standard deviation divided by the mean). Which of these is the more appropriate measure depends on what model of the impact of tax on investment is being considered. Here, it is assumed that a 1 percentage point change in the tax rate has the same impact regardless of the level of the rate, i.e. that tax affects investment in a linear way. See Appendix A for further discussion of this issue.
} 
Taxing profits in a changing world

TABLE 4.1

Within-country variation in domestic EMTR

\begin{tabular}{|c|c|c|c|c|c|c|c|c|c|c|c|}
\hline & Aus & Can & Fra & Ger & Ire & Ita & Jap & Spa & $U K$ & $U S$ & Ave. \\
\hline \multirow[t]{2}{*}{1979} & 46.1 & 17.8 & 25.1 & 46.9 & -5.5 & 1.3 & 41.8 & 18.4 & 4.7 & 20.1 & 21.7 \\
\hline & 60.3 & 53.4 & 65.5 & 96.0 & 53.7 & 35.6 & 64.3 & 33.4 & 68.0 & 59.9 & 59.0 \\
\hline \multirow[t]{2}{*}{1980} & 46.1 & 19.5 & 25.1 & 46.9 & -5.5 & 1.3 & 41.8 & 18.4 & 4.7 & 20.1 & 21.8 \\
\hline & 60.3 & 57.0 & 65.5 & 96.0 & 53.7 & 35.6 & 64.3 & 33.4 & 68.0 & 59.9 & 59.4 \\
\hline \multirow[t]{2}{*}{1981} & 46.4 & 20.0 & 19.0 & 46.9 & -2.3 & 1.3 & 41.8 & 18.4 & -0.6 & 15.8 & 20.7 \\
\hline & 60.2 & 57.3 & 67.9 & 96.0 & 9.2 & 35.6 & 64.3 & 33.4 & 67.4 & 57.9 & 54.9 \\
\hline \multirow[t]{2}{*}{1982} & 32.6 & 20.0 & 19.5 & 46.9 & -2.3 & 2.2 & 41.8 & 18.4 & -0.6 & 15.8 & 19.4 \\
\hline & 58.5 & 57.3 & 67.5 & 96.0 & 9.2 & 38.7 & 64.3 & 33.4 & 67.4 & 57.9 & 55.0 \\
\hline \multirow[t]{2}{*}{1983} & 32.6 & 22.9 & 19.4 & 39.4 & -2.3 & 3.4 & 46.2 & 18.4 & -1.6 & 15.8 & 19.4 \\
\hline & 58.5 & 54.7 & 67.6 & 93.2 & 9.2 & 41.9 & 69.3 & 33.4 & 63.1 & 57.9 & 54.9 \\
\hline \multirow[t]{2}{*}{1984} & 29.0 & 21.9 & 19.4 & 39.4 & -2.3 & 4.7 & 46.2 & 20.3 & 5.4 & 15.8 & 20.0 \\
\hline & 56.9 & 52.9 & 67.6 & 93.2 & 9.2 & 50.8 & 69.3 & 36.3 & 52.5 & 57.9 & 54.7 \\
\hline \multirow[t]{2}{*}{1985} & 29.0 & 23.9 & 19.4 & 31.9 & -2.3 & 4.7 & 46.2 & 18.1 & 11.0 & 15.8 & 19.8 \\
\hline & 56.9 & 56.4 & 67.6 & 88.5 & 9.2 & 50.8 & 69.3 & 36.6 & 44.1 & 57.9 & 53.8 \\
\hline \multirow[t]{2}{*}{1986} & 37.1 & 23.9 & 20.1 & 31.9 & -2.3 & 4.7 & 46.2 & 18.1 & 17.6 & 15.8 & 21.3 \\
\hline & 63.0 & 56.4 & 54.4 & 88.5 & 9.2 & 50.8 & 69.3 & 36.6 & 36.5 & 57.9 & 52.3 \\
\hline \multirow[t]{2}{*}{1987} & 40.8 & 21.0 & 18.8 & 31.9 & -2.3 & 4.7 & 46.2 & 18.1 & 18.0 & 20.5 & 22.8 \\
\hline & 64.6 & 51.2 & 55.6 & 88.5 & 9.2 & 50.8 & 69.3 & 36.6 & 36.2 & 40.1 & 50.2 \\
\hline \multirow[t]{2}{*}{1988} & 26.9 & 25.8 & 15.7 & 31.9 & -0.3 & 13.2 & 46.2 & 18.1 & 18.4 & 20.5 & 21.6 \\
\hline & 44.4 & 44.0 & 50.3 & 88.5 & 8.7 & 53.5 & 69.3 & 36.6 & 36.0 & 40.1 & 47.1 \\
\hline \multirow[t]{2}{*}{1989} & 31.3 & 26.7 & 13.5 & 31.9 & 1.9 & 13.2 & 46.2 & 21.8 & 18.4 & 20.5 & 22.5 \\
\hline & 43.4 & 42.6 & 44.9 & 88.5 & 8.1 & 53.5 & 69.3 & 36.1 & 36.0 & 40.1 & 46.3 \\
\hline \multirow[t]{2}{*}{1990} & 31.3 & 27.4 & 12.2 & 24.1 & 1.9 & 17.9 & 44.2 & 21.1 & 17.3 & 20.5 & 21.8 \\
\hline & 43.4 & 40.5 & 41.5 & 73.2 & 8.1 & 54.2 & 64.7 & 36.0 & 34.6 & 40.1 & 43.6 \\
\hline \multirow[t]{2}{*}{1991} & 35.7 & 28.6 & 10.6 & 26.6 & 4.4 & 19.2 & 43.5 & 22.6 & 16.4 & 20.5 & 22.8 \\
\hline & 42.4 & 38.4 & 36.6 & 77.5 & 7.7 & 57.0 & 62.5 & 38.2 & 33.3 & 40.1 & 43.4 \\
\hline \multirow[t]{2}{*}{1992} & 33.2 & 27.8 & 9.0 & 26.6 & 3.9 & 19.2 & 43.5 & 21.1 & 16.4 & 20.5 & 22.1 \\
\hline & 42.1 & 41.0 & 38.5 & 77.5 & 7.8 & 57.0 & 62.5 & 36.0 & 33.3 & 40.1 & 43.6 \\
\hline \multirow[t]{2}{*}{1993} & 20.9 & 24.9 & 8.5 & 24.1 & 3.9 & 24.0 & 43.5 & 20.4 & 12.4 & 22.4 & 20.5 \\
\hline & 33.5 & 37.2 & 37.6 & 73.2 & 7.8 & 66.7 & 62.5 & 36.3 & 32.7 & 42.2 & 43.0 \\
\hline \multirow[t]{2}{*}{1994} & 20.9 & 23.8 & 8.5 & 19.2 & 3.9 & 25.4 & 43.5 & 20.4 & 17.3 & 22.4 & 20.5 \\
\hline & 33.5 & 35.7 & 37.6 & 62.7 & 7.8 & 68.9 & 62.5 & 36.3 & 32.8 & 42.2 & 42.0 \\
\hline
\end{tabular}

Key: Aus $=$ Australia; Can $=$ Canada Fra $=$ France , Ger $=$ Germany; Ire $=$ Ireland; Ita = Italy; Jap = Japan; Spa = Spain; Ave. = average.

Note: Authors' own calculations. See Appendix A for sources and definition of EMTR. Weights used are: $28 \%$ buildings, 50\% plant and machinery, $22 \%$ inventories; $55 \%$ retained earnings, $10 \%$ new equity, 35\% debt. Inflation is held constant at $3.5 \%$ and the real interest rate at $10 \%$. Economic depreciation rates are $3.61 \%$ for buildings, $12.25 \%$ for plant and machinery and $0 \%$ for inventories. The standard deviations are shown in italics. They measure the variation across the nine finance-asset pairs.

Comparison can be made across countries as well. In 1979 , the degree of neutrality with respect to type of finance and asset was similar across many countries, with Germany having exceptionally high variation 
(indicating a low degree of neutrality) and Italy and Spain having noticeably lower standard deviations. By 1994, three countries had higher standard deviations than the other countries - Germany, Italy and Japan while Ireland had a very low standard deviation.

\section{Convergence between countries}

Turning to the issue of whether tax rates have converged between countries, Table 4.2 shows the weighted means and standard deviations of the 10 domestic EMTRs for each type of asset, each source of finance and the overall average. For example, the first column shows the mean of the 10 individual country EMTRs on an investment in buildings (where these were calculated using a weighted average across the three types of finance). The standard deviation shows the degree of variation across the 10 countries.

The final column of Table 4.1 shows the mean and standard deviation of the 10 individual country EMTRs, where these were calculated as the weighted average across types of finance and assets. The mean remains fairly constant, rising and falling slightly. The standard deviation, however, falls by nearly one-third. If Japan is excluded from the analysis, the average mean falls from 19.4 to 18.0 and the standard deviation declines by more than one-half, from 18.3 to 7.2. This indicates a significant degree of convergence between countries over this time period. 16

There is a large difference in both the magnitude and the direction of change across the different assets and types of finance. The mean EMTR on investment in buildings has remained fairly constant in the mid- to

\footnotetext{
${ }^{16}$ Note that this result is just as strong if the coefficient of variation is considered rather than the standard deviation.
} 
Taxing profits in a changing world

high twenties, while its standard deviation has fallen. 
TABLE 4.2

Means and standard deviations of domestic EMTRs

\begin{tabular}{|c|c|c|c|c|c|c|c|}
\hline & Buildings & $\begin{array}{r}\text { Plant \& } \\
\text { machinery }\end{array}$ & $\begin{array}{r}\text { Invent- } \\
\text { ories }\end{array}$ & $\begin{array}{l}\text { Retained } \\
\text { earnings }\end{array}$ & $\begin{array}{r}\text { New } \\
\text { equity }\end{array}$ & $\overline{D e b t}$ & Ave. \\
\hline \multirow[t]{2}{*}{1979} & 29.2 & 0.5 & 60.1 & 61.0 & 13.0 & -37.7 & 21.7 \\
\hline & 33.2 & 19.6 & 18.1 & 31.5 & 44.0 & 11.7 & 18.6 \\
\hline \multirow[t]{2}{*}{1980} & 29.4 & 0.5 & 60.6 & 61.4 & 13.3 & -37.9 & 21.8 \\
\hline & 33.2 & 19.6 & 18.4 & 31.4 & 44.3 & 11.6 & 18.6 \\
\hline \multirow[t]{2}{*}{1981} & 28.3 & 1.2 & 55.1 & 57.5 & 13.8 & -35.2 & 20.7 \\
\hline & 32.8 & 18.3 & 24.5 & 34.9 & 43.5 & 14.8 & 18.8 \\
\hline \multirow[t]{2}{*}{1982} & 25.7 & 0.1 & 55.4 & 56.3 & 12.4 & -36.5 & 19.4 \\
\hline & 29.3 & 17.4 & 24.1 & 33.7 & 40.9 & 13.8 & 17.0 \\
\hline \multirow[t]{2}{*}{1983} & 25.2 & 0.4 & 55.4 & 56.4 & 13.3 & -36.9 & 19.4 \\
\hline & 28.1 & 16.5 & 22.6 & 32.4 & 42.6 & 14.1 & 16.6 \\
\hline \multirow[t]{2}{*}{1984} & 25.6 & 1.6 & 54.6 & 57.5 & 12.1 & -36.8 & 20.0 \\
\hline & 24.4 & 14.7 & 20.3 & 31.2 & 43.6 & 13.3 & 15.3 \\
\hline \multirow[t]{2}{*}{1985} & 24.4 & 2.2 & 53.8 & 57.0 & 11.9 & -36.5 & 19.8 \\
\hline & 19.6 & 13.6 & 20.5 & 29.2 & 44.4 & 13.8 & 14.0 \\
\hline \multirow[t]{2}{*}{1986} & 25.6 & 5.2 & 52.5 & 58.0 & 15.1 & -34.5 & 21.3 \\
\hline & 19.9 & 12.6 & 21.2 & 29.3 & 44.4 & 14.7 & 14.4 \\
\hline \multirow[t]{2}{*}{1987} & 27.7 & 6.2 & 49.7 & 57.3 & 13.4 & -31.6 & 21.8 \\
\hline & 21.6 & 12.3 & 21.3 & 29.9 & 45.2 & 13.5 & 14.8 \\
\hline \multirow[t]{2}{*}{1988} & 27.7 & 7.7 & 45.5 & 55.7 & 12.1 & -29.1 & 21.6 \\
\hline & 16.9 & 10.7 & 16.7 & 28.2 & 41.3 & 13.7 & 12.3 \\
\hline \multirow[t]{2}{*}{1989} & 28.3 & 9.6 & 44.6 & 56.2 & 13.7 & -27.9 & 22.5 \\
\hline & 16.4 & 10.8 & 16.4 & 27.7 & 41.5 & 14.5 & 12.3 \\
\hline \multirow[t]{2}{*}{1990} & 27.0 & 9.8 & 42.3 & 53.4 & 16.5 & -26.3 & 21.8 \\
\hline & 15.5 & 9.8 & 14.5 & 23.3 & 41.5 & 12.5 & 11.3 \\
\hline \multirow[t]{2}{*}{1991} & 27.4 & 11.7 & 42.2 & 54.1 & 19.6 & -25.5 & 22.8 \\
\hline & 14.7 & 10.5 & 14.8 & 23.4 & 44.8 & 13.9 & 11.5 \\
\hline \multirow[t]{2}{*}{1992} & 26.6 & 10.8 & 42.0 & 53.5 & 17.4 & -25.9 & 22.1 \\
\hline & 14.0 & 10.8 & 14.9 & 23.5 & 46.3 & 13.5 & 11.5 \\
\hline \multirow[t]{2}{*}{1993} & 25.0 & 9.1 & 40.6 & 51.3 & 15.2 & -26.4 & 20.5 \\
\hline & 15.5 & 10.0 & 13.2 & 24.3 & 45.0 & 13.5 & 10.9 \\
\hline \multirow[t]{2}{*}{1994} & 25.4 & 9.3 & 39.8 & 50.7 & 16.1 & -25.6 & 20.5 \\
\hline & 14.9 & 9.8 & 12.5 & 22.8 & 43.9 & 12.9 & 10.5 \\
\hline
\end{tabular}

Note: Authors' own calculations. See Appendix A for sources and definition of EMTR. Weights used are: $28 \%$ buildings, $50 \%$ plant and machinery, $22 \%$ inventories; $55 \%$ retained earnings, $10 \%$ new equity, 35\% debt. Inflation is held constant at $3.5 \%$ and the real interest rate at $10 \%$. Economic depreciation rates are $3.61 \%$ for buildings, $12.25 \%$ for plant and machinery and $0 \%$ for inventories. The standard deviations are shown in italics. They measure the variation across the 10 country means. 


\section{Taxing profits in a changing world}

Investment in industrial plant and machinery, which enjoyed very favourable depreciation allowances in some countries at the beginning of this period, is taxed more heavily by the end of the period, though also more similarly across countries, as indicated by the reduction in the standard deviation from 19.6 to 9.8. Due to the decline in statutory tax rates, the EMTR on investment in inventories is lower in 1994 than at the beginning of the period, with only a slightly lower degree of variation between countries.

Turning to the EMTRs calculated by type of finance (weighted across the three types of asset), there is less change. Investment financed by retained earnings is taxed slightly less at the end of the period, but still shows a wide dispersion across countries. The tax rate for investment financed by new equity increases slightly over time, although it remains much lower than that for retained earnings. Debt-financed investment remains the most favourably treated, although less so in 1994 than in 1979. EMTRs can be negative if the depreciation allowance given in the tax code is greater than the assumed economic depreciation rate, thus giving an effective subsidy to this form of investment. In the case of debt, EMTRs can also be negative because nominal (rather than real) interest payments are deductible from the tax base, while inflation is greater than zero.

\section{Varying economic conditions}

The calculations presented so far have been made assuming that inflation and interest rates were constant across countries and over time. This is a useful way to isolate the impact of changes in tax rules, since it abstracts from the prevailing economic conditions. However, different countries have had quite different experiences of inflation over this period, and this 
influences the effective tax rate in a number of ways. Ideally, the required rate of return could be calculated using actual inflation and interest rates. However, the methodology used here is not suitable for calculating ETRs when real interest rates are negative, which occurred in some countries during the earlier years of the period covered here (see Figure 1.3). Therefore the EMTRs shown in Figure 4.2 are calculated using the

\section{FIGURE 4.2}

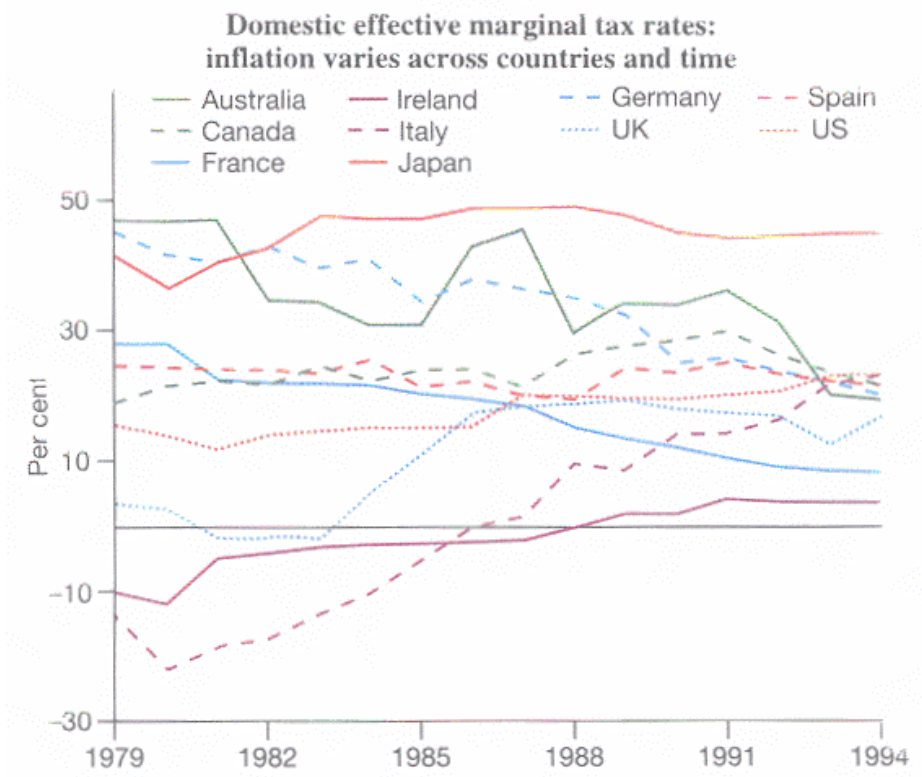

Notes: Authors' own calculations. Weighted average across both finance and assets. Weights used are: $28 \%$ buildings, $50 \%$ plant and machinery, $22 \%$ inventories; $55 \%$ retained earnings, $10 \%$ new equity, $35 \%$ debt. Economic depreciation rates are $3.61 \%$ for buildings, $12.25 \%$ for plant and machinery and $0 \%$ for inventories. Inflation is the long-term rate from $O E C D$ Economic Outlook; the real interest rate is inflation plus 10 percentage points. See Appendix $A$ for definition and interpretation of EMTR.

actual inflation rate plus 10 percentage points as the real interest rate. The inflation rates are shown in Figure 4.3. They have clearly declined over the period considered and become more similar across these countries. 


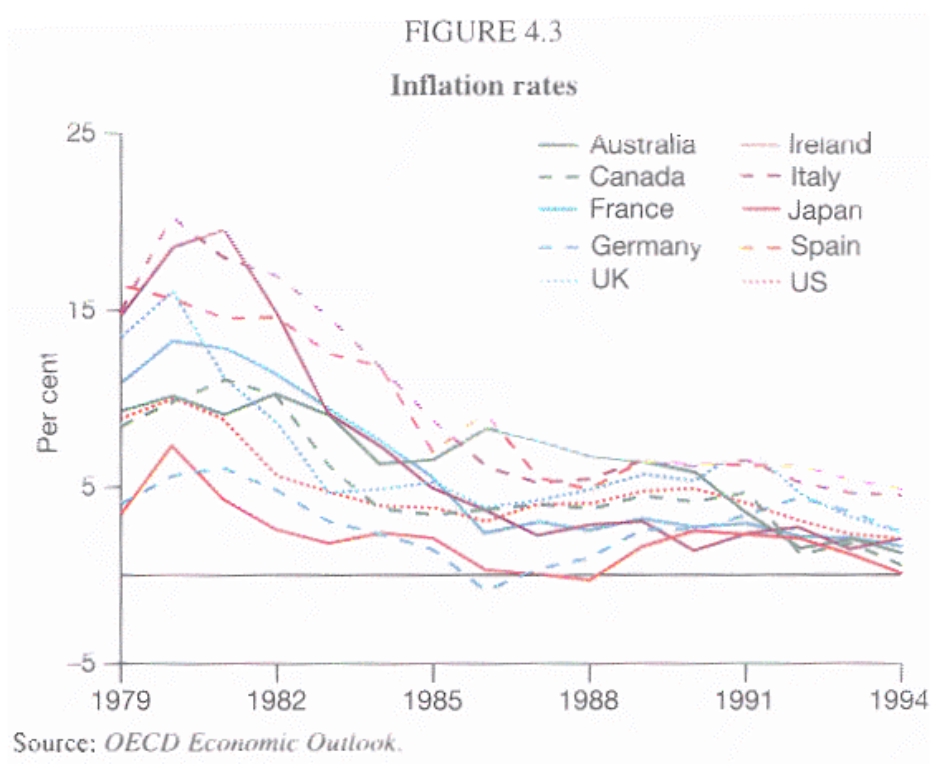

The EMTRs shown in Figure 4.2 exhibit a stronger pattern of convergence than those presented in Figure 4.1 , where inflation was held constant. This is due to the higher degree of dispersion in EMTRs at the beginning of the period, caused by the variation in inflation rates. Table 4.3 shows the mean and standard deviation of the 10 domestic EMTRs (calculated using the OECD weights) for each type of asset, each source of finance and the overall average. This is the same information as that presented in Table 4.2, but using the EMTRs calculated with actual inflation rates. Table 4.3 indicates the extent to which tax rates have converged between countries, when changes in inflation are considered in addition to changes in the tax system.

The EMTR for buildings rises, in contrast with the EMTRs calculated using constant inflation shown in Table 4.2. The standard deviation, indicating the degree of variation between the treatment of industrial buildings in different countries, exhibits a similar 


\section{Effective tax rates}

TABLE 4.3

Means and standard deviations of domestic EMTRs: inflation varies across countries and time

\begin{tabular}{|c|c|c|c|c|c|c|c|}
\hline & Buildings & $\begin{array}{r}\text { Plant \& } \\
\text { machinery }\end{array}$ & $\begin{array}{r}\text { Invent- } \\
\text { ories }\end{array}$ & $\begin{array}{l}\text { Retained } \\
\text { earnings }\end{array}$ & $\begin{array}{r}\text { New } \\
\text { equity }\end{array}$ & Debt & Ave. \\
\hline \multirow[t]{2}{*}{1979} & 18.1 & -5.7 & 80.8 & 76.6 & 8.2 & -65.5 & 20.0 \\
\hline & 37.3 & 27.4 & 46.6 & 27.8 & 63.5 & 18.9 & 21.7 \\
\hline \multirow[t]{2}{*}{1980} & 13.9 & -7.8 & 82.6 & 81.8 & 3.1 & -77.6 & 18.1 \\
\hline & 38.3 & 30.0 & 58.6 & 28.6 & 71.2 & 20.9 & 22.6 \\
\hline \multirow[t]{2}{*}{1981} & 17.3 & -3.5 & 69.3 & 72.9 & 7.5 & -64.2 & 18.4 \\
\hline & 33.6 & 23.7 & 50.5 & 35.9 & 67.1 & 22.7 & 21.6 \\
\hline \multirow[t]{2}{*}{1982} & 17.2 & -4.3 & 69.5 & 69.1 & 7.9 & -59.4 & 18.0 \\
\hline & 31.5 & 21.2 & 46.1 & 34.1 & 62.4 & 21.9 & 20.3 \\
\hline \multirow[t]{2}{*}{1983} & 19.9 & -2.1 & 64.6 & 64.7 & 10.9 & -51.1 & 18.8 \\
\hline & 29.8 & 17.7 & 37.7 & 32.0 & 57.5 & 21.0 & 19.8 \\
\hline \multirow[t]{2}{*}{1984} & 22.3 & 0.0 & 60.4 & 63.4 & 9.3 & -46.5 & 19.5 \\
\hline & 27.1 & 15.8 & 31.6 & 30.0 & 56.3 & 20.2 & 18.3 \\
\hline \multirow[t]{2}{*}{1985} & 22.5 & 1.0 & 58.6 & 60.3 & 11.0 & -41.6 & 19.7 \\
\hline & 21.2 & 14.0 & 28.1 & 27.4 & 51.3 & 16.9 & 16.0 \\
\hline \multirow[t]{2}{*}{1986} & 24.5 & 4.5 & 61.1 & 59.2 & 19.9 & -34.3 & 22.6 \\
\hline & 20.9 & 12.2 & 31.5 & 27.0 & 48.0 & 16.2 & 16.8 \\
\hline \multirow[t]{2}{*}{1987} & 26.9 & 5.7 & 56.3 & 58.0 & 17.0 & -31.1 & 22.7 \\
\hline & 21.5 & 11.7 & 30.4 & 28.3 & 47.9 & 13.5 & 16.6 \\
\hline \multirow[t]{2}{*}{1988} & 27.2 & 7.2 & 49.8 & 55.8 & 14.1 & -28.3 & 22.2 \\
\hline & 17.4 & 9.8 & 22.9 & 24.9 & 42.7 & 12.4 & 13.7 \\
\hline \multirow[t]{2}{*}{1989} & 27.1 & 9.4 & 48.0 & 58.8 & 14.4 & -31.3 & 22.8 \\
\hline & 16.9 & 10.8 & 21.0 & 26.2 & 46.1 & 14.5 & 13.4 \\
\hline \multirow[t]{2}{*}{1990} & 26.1 & 9.8 & 44.5 & 55.6 & 17.2 & -29.4 & 22.0 \\
\hline & 15.6 & 9.8 & 19.0 & 22.9 & 45.0 & 13.0 & 12.0 \\
\hline \multirow[t]{2}{*}{1991} & 26.2 & 11.5 & 43.6 & 56.7 & 18.1 & -29.5 & 22.7 \\
\hline & 15.2 & 10.6 & 18.0 & 23.2 & 49.1 & 16.5 & 12.0 \\
\hline \multirow[t]{2}{*}{1992} & 26.2 & 10.4 & 40.6 & 53.5 & 14.9 & -26.9 & 21.5 \\
\hline & 14.4 & 10.4 & 15.4 & 23.7 & 47.6 & 17.4 & 11.4 \\
\hline \multirow[t]{2}{*}{1993} & 24.9 & 8.9 & 40.0 & 50.6 & 13.6 & -25.6 & 20.2 \\
\hline & 15.7 & 9.4 & 14.9 & 24.6 & 45.2 & 16.2 & 11.1 \\
\hline \multirow[t]{2}{*}{1994} & 25.6 & 9.0 & 39.2 & 48.5 & 14.5 & -22.5 & 20.3 \\
\hline & 15.1 & 8.8 & 15.2 & 22.7 & 42.2 & 14.6 & 10.8 \\
\hline
\end{tabular}

Note: Authors' own calculations. See Appendix A for sources and definition of EMTR. Weights used are: $28 \%$ buildings, $50 \%$ plant and machinery, $22 \%$ inventories; $55 \%$ retained earnings, $10 \%$ new equity, $35 \%$ debt. The real interest rate is 10 percentage points above the actual inflation rate. Economic depreciation rates are $3.61 \%$ for buildings, $12.25 \%$ for plant and machinery and $0 \%$ for inventories. The standard deviations are shown in italics. They measure the variation across the 10 country means. 
Taxing profits in a changing world

pattern, however, falling substantially over the period. The EMTR on plant and machinery rises by more and the standard deviation falls by more over the period when actual inflation rates, rather than constant rates, are used. The EMTR on inventories falls by more than seen under constant inflation, because it starts the period at a higher level. ${ }^{17}$ For types of finance, the picture is quite similar whether fixed or actual inflation rates are used, except in the case of debt. The EMTR on debtfinanced investment is lower in countries with high inflation than in countries with low inflation. The distortionary effect of high inflation can be somewhat mitigated by the indexation of capital allowances (although none of the countries considered here actually does this).

\section{Effective average tax rate}

The EATR, which shows the tax rate for an investment earning economic rent, can be calculated at any level of profitability. Figure 4.4 shows the EATR on a domestic investment earning a real rate of return of 40 per cent in the absence of tax. For some countries, this is quite different from both the statutory tax rate and the EMTR. Care needs to be taken in comparing actual levels of the different measures of tax rates, since a small difference in one measure might have a larger impact than the same-sized difference for another measure. However, one noticeable difference in the patterns of the two ETRs is that the EATR for Japan is at a similar level to that for other countries, while the EMTR (shown in Figure 4.1) was significantly higher than the EMTRs for

\footnotetext{
${ }^{17}$ The impact of inflation on investment in inventories depends, in part, on whether the LIFO (last in, first out) or FIFO (first in, first out) method of inventories valuation is used. Generally, the EMTR is higher using FIFO than using LIFO when inflation is high.
} 
FIGURE 4.4

Domestic effective average tax rates

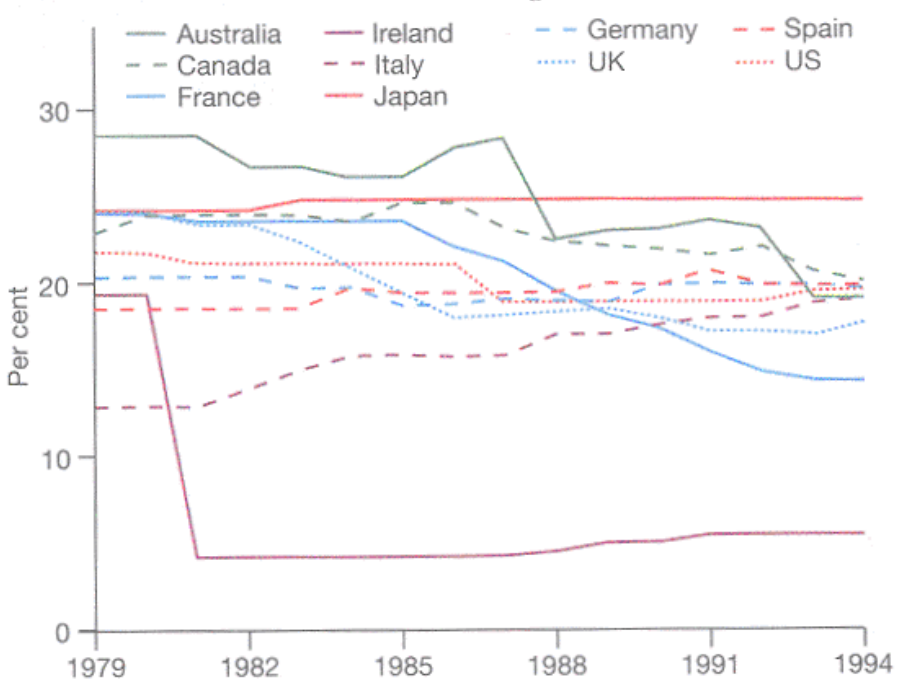

Note: Authors' own calculations. See Appendix A for sources and definition of EATR. Weighted average across both finance and assets. Weights used are: $28 \%$ buildings, $50 \%$ plant and machinery, $22 \%$ inventories; $55 \%$ retained earnings, $10 \%$ new equity, $35 \%$ debt. Economic depreciation rates are $3.61 \%$ for buildings, $12.25 \%$ for plant and machinery and $0 \%$ for inventories. Inflation is held constant at

$3.5 \%$ and the real interest rate at $10 \%$.

other countries. The EATR does not indicate the same degree of convergence over time between countries that was shown by the EMTR, even when Ireland is excluded from the analysis.

Table 4.4 shows the means and standard deviations of the 10 domestic EATRs (calculated using the OECD weights) for each type of asset, each source of finance and the overall average. Similarly to Table 4.2, the first column shows the mean of the weighted EATR on an investment in buildings (weighted across the three types of finance) over the 10 countries. The standard deviation shows the degree of variation across the 10 countries. 
Taxing profits in a changing world

TABLE 4.4

Means and standard deviations of domestic EATRs

\begin{tabular}{|c|c|c|c|c|c|c|c|}
\hline & Buildings & $\begin{array}{r}\text { Plant \& } \\
\text { machinery }\end{array}$ & $\begin{array}{r}\text { Invent- } \\
\text { ories }\end{array}$ & $\begin{array}{l}\text { Retained } \\
\text { earnings }\end{array}$ & $\begin{array}{r}\text { New } \\
\text { equity }\end{array}$ & Debt & Ave. \\
\hline \multirow[t]{2}{*}{1979} & 22.0 & 21.7 & 21.5 & 37.7 & 21.3 & -3.2 & 21.7 \\
\hline & 6.4 & 5.0 & 15.9 & 7.0 & 16.4 & 7.8 & 4.2 \\
\hline \multirow[t]{2}{*}{1980} & 22.1 & 21.8 & 21.6 & 37.8 & 21.5 & -3.2 & 21.8 \\
\hline & 6.5 & 4.9 & 15.9 & 7.0 & 16.5 & 7.8 & 4.2 \\
\hline \multirow[t]{2}{*}{1981} & 20.6 & 20.2 & 19.2 & 35.1 & 20.1 & -3.4 & 20.1 \\
\hline & 8.5 & 7.6 & 16.1 & 11.8 & 17.4 & 7.8 & 6.9 \\
\hline \multirow[t]{2}{*}{1982} & 20.3 & 20.2 & 19.3 & 35.1 & 20.1 & -3.7 & 20.1 \\
\hline & 8.0 & 7.4 & 16.1 & 11.6 & 16.9 & 7.5 & 6.6 \\
\hline \multirow[t]{2}{*}{1983} & 20.3 & 20.4 & 19.0 & 35.2 & 20.5 & -4.0 & 20.1 \\
\hline & 7.9 & 7.4 & 15.9 & 11.5 & 16.8 & 7.8 & 6.5 \\
\hline \multirow[t]{2}{*}{1984} & 20.3 & 20.5 & 18.4 & 35.5 & 19.3 & -4.1 & 20.0 \\
\hline & 7.6 & 7.3 & 15.8 & 11.3 & 18.0 & 7.8 & 6.3 \\
\hline \multirow[t]{2}{*}{1985} & 20.1 & 20.4 & 18.2 & 35.2 & 18.9 & -4.2 & 19.8 \\
\hline & 7.4 & 7.4 & 15.6 & 11.2 & 18.4 & 8.1 & 6.3 \\
\hline \multirow[t]{2}{*}{1986} & 20.1 & 20.3 & 17.8 & 34.9 & 19.1 & -4.1 & 19.7 \\
\hline & 7.5 & 7.5 & 15.5 & 11.3 & 18.7 & 8.2 & 6.5 \\
\hline \multirow[t]{2}{*}{1987} & 19.9 & 19.7 & 17.6 & 34.1 & 17.6 & -3.4 & 19.3 \\
\hline & 7.6 & 7.4 & 15.2 & 11.3 & 18.5 & 8.0 & 6.4 \\
\hline \multirow[t]{2}{*}{1988} & 19.4 & 19.1 & 16.5 & 33.1 & 16.7 & -3.5 & 18.6 \\
\hline & 6.9 & 7.1 & 14.0 & 10.8 & 17.5 & 7.8 & 5.5 \\
\hline \multirow[t]{2}{*}{1989} & 19.5 & 19.2 & 16.3 & 32.9 & 16.9 & -3.3 & 18.6 \\
\hline & 6.8 & 7.0 & 13.8 & 10.7 & 17.3 & 7.9 & 5.4 \\
\hline \multirow[t]{2}{*}{1990} & 19.1 & 18.7 & 17.7 & 32.1 & 17.6 & -2.3 & 18.6 \\
\hline & 6.6 & 6.5 & 10.5 & 9.9 & 17.1 & 5.6 & 5.4 \\
\hline \multirow[t]{2}{*}{1991} & 19.1 & 18.9 & 17.3 & 32.1 & 18.2 & -2.4 & 18.6 \\
\hline & 6.5 & 6.6 & 10.9 & 10.0 & 17.6 & 6.1 & 5.4 \\
\hline \multirow[t]{2}{*}{1992} & 18.9 & 18.7 & 17.1 & 32.0 & 16.8 & -2.5 & 18.4 \\
\hline & 6.4 & 6.7 & 10.8 & 10.0 & 19.3 & 6.0 & 5.4 \\
\hline \multirow[t]{2}{*}{1993} & 18.4 & 18.3 & 16.4 & 31.4 & 16.1 & -2.8 & 17.9 \\
\hline & 6.5 & 6.8 & 10.1 & 10.2 & 19.2 & 5.6 & 5.1 \\
\hline \multirow[t]{2}{*}{1994} & 18.4 & 18.1 & 16.9 & 31.1 & 16.4 & -2.4 & 17.9 \\
\hline & 6.3 & 6.6 & 9.3 & 9.9 & 18.8 & 5.1 & 5.1 \\
\hline
\end{tabular}

Note: Authors' own calculations. See Appendix A for sources and definition of EATR. Weights used are: $28 \%$ buildings, $50 \%$ plant and machinery, $22 \%$ inventories; $55 \%$ retained earnings, $10 \%$ new equity, 35\% debt. Inflation is held constant at $3.5 \%$ and the real interest rate at $10 \%$. Economic depreciation rates are $3.61 \%$ for buildings, $12.25 \%$ for plant and machinery and $0 \%$ for inventories. The standard deviations are shown in italics. They measure the variation across the 10 country means.

Overall, the mean decreases slightly, and the standard deviation increases slightly (largely due to the much lower Irish tax rate), indicating that there has been little convergence in EATRs. 


\subsection{Effective Tax Rates for Foreign Direct Investment}

The discussion so far has considered the taxation of domestic capital. The situation is further complicated by addressing the possibility of investment flows that cross international borders. In this section, EMTRs for an investment made by a parent company in one country (known as the source country) into its wholly-owned subsidiary in another country (known as the residence country) are presented. These international EMTRs are calculated following the methodology laid out in OECD (1991). ${ }^{18}$ A number of additional aspects of the tax systems need to be accounted for when calculating the effective tax rate on cross-border investment flows. In addition to the taxation in the source country, crossborder investments are often subject to withholding taxes when profits are repatriated to the parent company. These profits may then be subject to further taxation in the residence country, depending on the treatment of foreign source income. Details of how these additional taxes are included in the calculations are given in Appendix A.

There are two aspects of international ETRs to consider. The first is the tax rate for an investment into a specific country, from any other country. This is called the source country ETR, since it encapsulates the ETR for the country in which the investment is being carried

\footnotetext{
${ }^{18}$ The EMTRs given below are weighted as in OECD (1991) unless otherwise stated. These weights are: for the parent company source of finance $-55 \%$ retained earnings, $10 \%$ new equity, $35 \%$ debt; for the subsidiary source of finance - 33\% retained earnings, 33\% new equity from the parent, $33 \%$ debt from the parent; for the type of asset - $28 \%$ buildings, $50 \%$ plant and machinery, $22 \%$ inventories. A constant inflation rate of $3.5 \%$ and real interest rate of $10 \%$ have been used in all countries in all years unless otherwise specified.
} 


\section{Taxing profits in a changing world}

out. The source country ETRs can be used to compare the favourability of alternative locations, and their variability is an indicator of the extent to which capital import neutrality holds (see Appendix A for definition). The second aspect of international ETRs to examine is the tax rate for an investment from a specific country, into any other country. This is called the residence country ETR, since it encapsulates the ETR for the country of residence of the investor. The residence country ETRs can be used to compare the attractiveness of alternative locations for outward investment, and their variability indicates the extent to which capital export neutrality holds (see Appendix A for definition).

\section{Effective tax rates for inward (source country) investment}

The source country EMTRs shown in Figure 4.5 are weighted averages, for each source country, of the EMTRs on investment from each of the nine residence countries (which are weighted across asset and finance types), using the proportions of inward FDI coming from each country (see Table A.1 in Appendix A) as weights. The weight for domestic investment is zero.

While for most countries the pattern over time is similar to that of the domestic EMTR shown in Figure 4.1 (with some notable exceptions), the overall picture looks quite different. First, the mean is substantially higher, indicating that, on average, it is more costly for foreign investors to invest in these countries than it is for domestic investors to do so. Most source countries levy withholding tax on repatriated profits, which increases the EMTR. In addition, most residence countries levy some tax on foreign source income and this usually leads to an increase in the EMTR, 
FIGURE 4.5

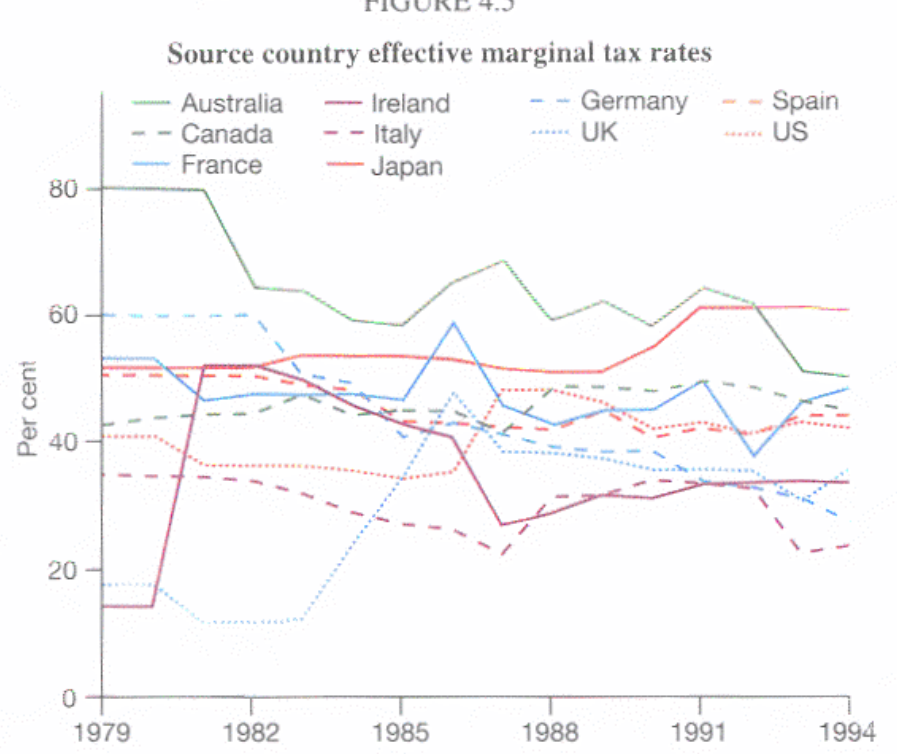

Note. Authors' own calculations. See Appendix A for sources and definition of EMTR. All rates are averaged across finance and assets. Weights used for assets: $28 \%$ buildings, $50 \%$ plant and machinery, $22 \%$ inventories; for parent company source of finance: $55 \%$ retained earnings, $10 \%$ new equity, $35 \%$ debt; for subsidiary source of finance: $33 \%$ retained earnings, $33 \%$ new equity from the parent, $33 \%$ debt from the parent. Inflation is held constant at $3.5 \%$ and the real interest rate at $10 \%$. Economic depreciation rates are $3.61 \%$ for buildings, $12.25 \%$ for plant and machinery and $0 \%$ for inventories. The rate is the weighted average of investment from the nine other countries, weighted by the proportion of inward FDI coming from each country (see Table A.1 in Appendix A).

depending on the method of taxing foreign source income and the statutory tax rates in the two countries. Second, the ranking of individual countries is noticeably different. Italy, for example, is about average when the domestic EMTRs are compared (in Figure 4.1) but here has the lowest EMTR of the 10 countries during the 1990s. It is worth noting that the EMTR for inward investment from the US has a large impact on most of

${ }^{19}$ See Table A.4 in Appendix A for how the method of taxing foreign source income affects the ETR calculation, and Table B.3 in Appendix B for the method of taxing foreign source income in each country. 
Taxing profits in a changing world

FIGURE 4.6

Source country effective average tax rates

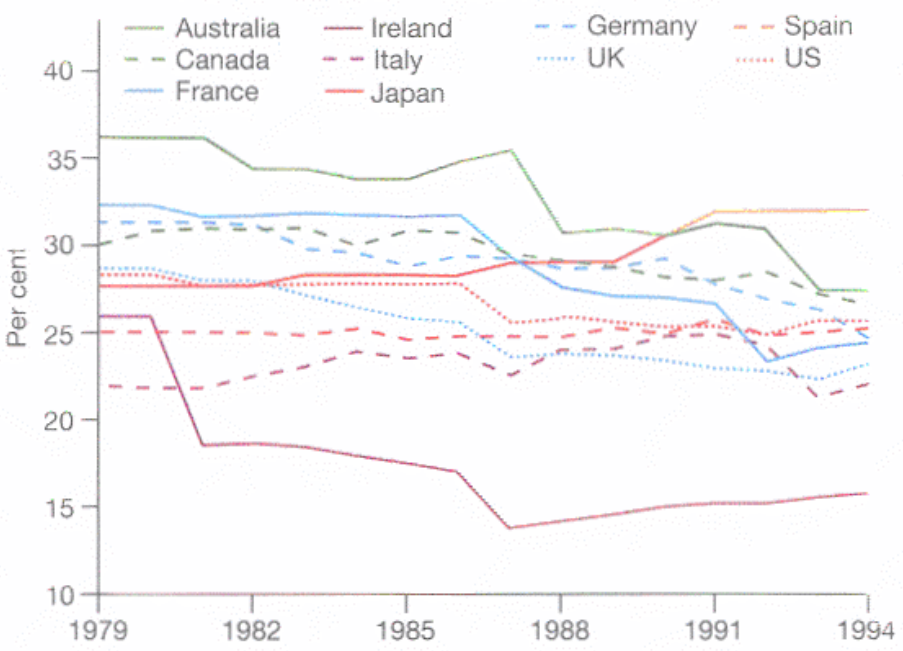

Note: Authors' uwn calculations. See Appendix A for sources and definition of EATR. All rates are averaged across finance and assets. Weights used for assets: $28 \%$ buildings, $50 \%$ plant and machinery, $22 \%$ inventories: for parent company source of finance: $55 \%$ retained earnings, $10 \%$ new equity, $35 \%$ debt: for subsidiary source of finance: $33 \%$ retained earnings, $33 \%$ new equity from the parent. $33 \%$ debt from the parent. Inflation is held constant at $3.5 \%$ and the real interest rate at $10 \%$. Economic depreciation rates are $3.61 \%$ for buildings, $12.25 \%$ for plant and machinery and $0 \%$ for inventories. The rate is the weighted average of investment from the nine other countries, weighted by the proportion of inward FDI coming from each country (see Table A.I in Appendix A).

these figures, since the US is the largest exporter of capital to many of these countries (see Table A.1 in Appendix A).

This extension of the ETR to international investment can also be applied to effective average tax rates. The EATRs shown in Figure 4.6 are weighted averages, by source country, of the EATRs on investment from each of the nine residence countries (which are weighted across asset and finance types), 


\section{Effective tax rates}

TABLE 4.5

Means and mean standard deviations

of source and residence country EMTRs and EATRs

\begin{tabular}{|c|c|c|c|c|}
\hline & $\begin{array}{l}\text { Source } \\
\text { EMTR }\end{array}$ & $\begin{array}{r}\text { Source } \\
\text { EATR }\end{array}$ & $\begin{array}{r}\text { Residence } \\
\text { EMTR }\end{array}$ & $\begin{array}{r}\text { Residence } \\
\text { EATR } \\
\end{array}$ \\
\hline \multirow[t]{2}{*}{1979} & 44.9 & 29.0 & 40.8 & 29.3 \\
\hline & 8.9 & 2.4 & 18.5 & 3.0 \\
\hline \multirow[t]{2}{*}{1980} & 45.0 & 29.1 & 40.9 & 29.3 \\
\hline & 8.8 & 2.4 & 18.5 & 3.1 \\
\hline \multirow[t]{2}{*}{1981} & 47.1 & 28.2 & 37.7 & 28.5 \\
\hline & 10.0 & 3.2 & 19.5 & 4.0 \\
\hline \multirow[t]{2}{*}{1982} & 45.6 & 28.1 & 37.4 & 28.6 \\
\hline & 10.1 & 3.2 & 18.7 & 3.8 \\
\hline \multirow[t]{2}{*}{1983} & 45.0 & 28.0 & 37.0 & 28.3 \\
\hline & 9.6 & 3.0 & 18.3 & 4.1 \\
\hline \multirow[t]{2}{*}{1984} & 44.4 & 27.9 & 39.1 & 28.1 \\
\hline & 9.5 & 3.0 & 14.7 & 4.1 \\
\hline \multirow[t]{2}{*}{1985} & 43.5 & 27.6 & 39.7 & 27.7 \\
\hline & 9.8 & 3.1 & 12.1 & 4.4 \\
\hline \multirow[t]{2}{*}{1986} & 45.7 & 27.6 & 42.8 & 27.5 \\
\hline & 11.4 & 3.2 & 12.8 & 4.8 \\
\hline \multirow[t]{2}{*}{1987} & 42.5 & 26.5 & 44.4 & 25.7 \\
\hline & 10.9 & 3.3 & 10.8 & 4.2 \\
\hline \multirow[t]{2}{*}{1988} & 42.5 & 25.9 & 43.9 & 25.7 \\
\hline & 11.9 & 3.3 & 9.0 & 3.5 \\
\hline \multirow[t]{2}{*}{1989} & 44.1 & 26.1 & 44.6 & 25.8 \\
\hline & 12.3 & 3.3 & 9.4 & 3.4 \\
\hline \multirow[t]{2}{*}{1990} & 43.1 & 26.1 & 42.9 & 25.7 \\
\hline & 10.3 & 2.7 & 9.0 & 3.4 \\
\hline \multirow[t]{2}{*}{1991} & 44.0 & 26.1 & 42.8 & 25.4 \\
\hline & 10.7 & 2.8 & 9.7 & 3.5 \\
\hline \multirow[t]{2}{*}{1992} & 41.8 & 25.5 & 40.2 & 24.6 \\
\hline & 10.6 & 3.2 & 9.1 & 3.3 \\
\hline \multirow[t]{2}{*}{1993} & 40.2 & 24.8 & 42.6 & 24.9 \\
\hline & 13.6 & 3.6 & 10.5 & 3.2 \\
\hline \multirow[t]{2}{*}{1994} & 40.5 & 24.8 & 44.6 & 25.2 \\
\hline & 15.2 & 3.5 & 10.2 & 2.9 \\
\hline
\end{tabular}

Note: Authors' own calculations. See Appendix A for sources and definitions of EMTR and EATR. The means are calculated using the weighted average of investment into or from each of the nine other countries, weighted by the proportion of inward or outward FDI into or from each country (see Tables A.1 and A.2 in Appendix A). Country measures are weighted averages using the following weights for assets: $28 \%$ buildings, $50 \%$ plant and machinery, $22 \%$ inventories; for parent company source of finance: $55 \%$ retained earnings, $10 \%$ new equity, $35 \%$ debt; for subsidiary source of finance: $33 \%$ retained earnings, $33 \%$ new equity from the parent, 33\% debt from the parent. Inflation is held constant at 3.5\% and the real interest rate at $10 \%$. Economic depreciation rates are $3.61 \%$ for buildings, $12.25 \%$ for plant and machinery and $0 \%$ for inventories. The figures in italics are the average of the standard deviations for each country. The data for each country are shown in the individual country appendices. 
using the proportions of inward FDI from Table A.1 in Appendix A as weights. They are calculated assuming a real rate of return of 40 per cent in the absence of tax. As in the domestic case, the distribution of EATRs is more compact, though care needs to be taken in interpreting these differences. A 1 percentage point difference in the EATR may have a larger impact on investment than a 1 percentage point difference in the EMTR. ${ }^{20}$ It is noticeable that, despite the rate-cutting reforms that have taken place, the source country EATR has fallen only slightly (the mean has fallen from 29.0 per cent in 1979 to 24.8 per cent in 1994).

The first two columns of Table 4.5 show the mean of the 10 source country ETRs and the mean of the standard deviations of the 10 source country ETRs (these are shown for each country in Appendices C-L). Both the mean EMTR and mean EATR fell over the period while the mean standard deviations rose. This increase in the average dispersion of tax rates faced by foreign investors in these countries indicates a reduction in the overall degree of capital import neutrality in these countries (see Appendix A for the definition of capital import neutrality and the individual country appendices for a discussion of the trends in each country).

\section{Effective tax rates for outward (residence country) investment}

Figure 4.7 shows the weighted average EMTRs by residence country into each of the nine source countries (which are weighted across asset and finance types), using the proportions of outward FDI flows going to each country (given in Table A.2 in Appendix A) as weights. The pattern of residence country EMTRs is

\footnotetext{
${ }^{20}$ This is suggested by the empirical work in Devereux and Griffith (1997).
} 
markedly different from that of either the domestic EMTRs (Figure 4.1) or the source country EMTRs

\section{FIGURE 4.7}

Residence country effective marginal tax rates

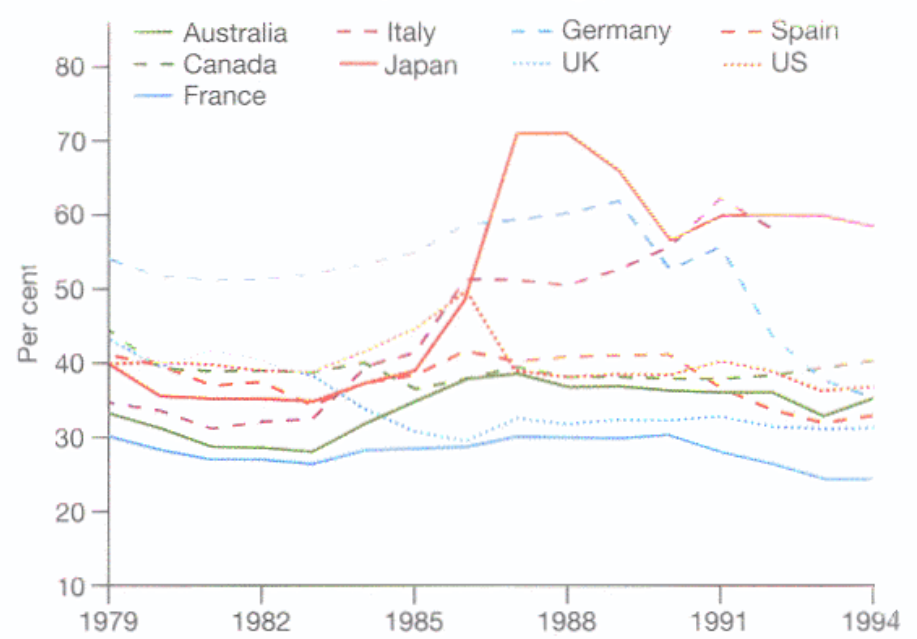

Note: Authors' own calculations. See Appendix A for sources and definition of EMTR. All rates are averaged across finance and assets. Weights used for assets: $28 \%$ buildings, $50 \%$ plant and machinery, $22 \%$ inventories; for parent company source of finance: $55 \%$ retained earnings, $10 \%$ new equity, $35 \%$ debt; for subsidiary source of finance: $33 \%$ retained earnings, $33 \%$ new equity from the parent. $33 \%$ debt from the parent. Inflation is held constant at $3.5 \%$ and the real interest rate at $10 \%$. Economic depreciation rates are $3.61 \%$ for buildings, $12.25 \%$ for plant and machinery and $0 \%$ for inventories. The rate is the weighted average of investment from the nine other countries, weighted by the proportion of outward FDI going to each country (see Table A.2 in Appendix A).

(Figure 4.5). As with the source country EMTRs, the mean of the residence country EMTRs is substantially higher than that of the domestic EMTRs, indicating that it is more costly, on average, for investors in these countries to undertake a foreign investment than it is for them to carry out a domestic investment. Again, this is due to the imposition of withholding taxes on repatriated profits and the treatment of foreign source income in the residence country. The mean of the residence country EMTRs has risen over the period, 
Taxing profits in a changing world

although if Italy and Japan are excluded from the analysis, it falls from 41.1 per cent to 34.0 per cent.

Figure 4.8 shows the weighted average residence country EATRs. These are averaged across the nine

FIGURE 4.8

Residence country effective average tax rates

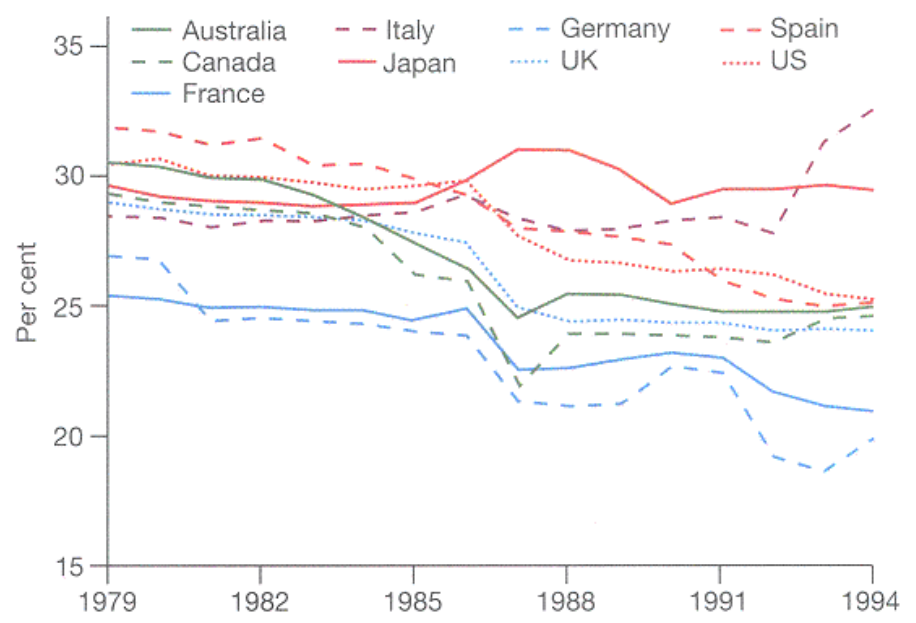

Note: Authors' own calculations. See Appendix A for sources and definition of EATR. All rates are averaged across finance and assets. Weights used for assets: $28 \%$ buildings. $50 \%$ plant and machinery, $22 \%$ inventories; for parent company source of finance: $55 \%$ retained earnings, $10 \%$ new equity, $35 \%$ debt; for subsidiary source of finance: $33 \%$ retained earnings, $33 \%$ new equity from the parent, $33 \%$ debt from the parent. Inflation is held constant at $3.5 \%$ and the real interest rate at $10 \%$. Economic depreciation rates are $3.61 \%$ for buildings. $12.25 \%$ for plant and machinery and $0 \%$ for inventories. The rate is the weighted average of investment from the nine other countries, weighted by the proportion of outward FDI going to each country (see Table A.2 in Appendix A).

source countries, using the proportions of outward FDI going to each country (from Table A.2 in Appendix A) as weights.

The mean of all 10 of the residence country EATRs is very similar to the mean of the source country EATRs; however, the individual country EATRs are quite different from the EMTRs. In particular, the dispersion of the residence country EATRs is less (notice the scales on the graphs are different). The final 
two columns of Table 4.5 show the mean of the 10 residence country ETRs and the mean of the standard deviations of the 10 residence country ETRs (these are shown for each country in the individual country appendices). The mean of the residence country EMTR rose over the period while the mean EATR fell. The

FIGURE 4.9

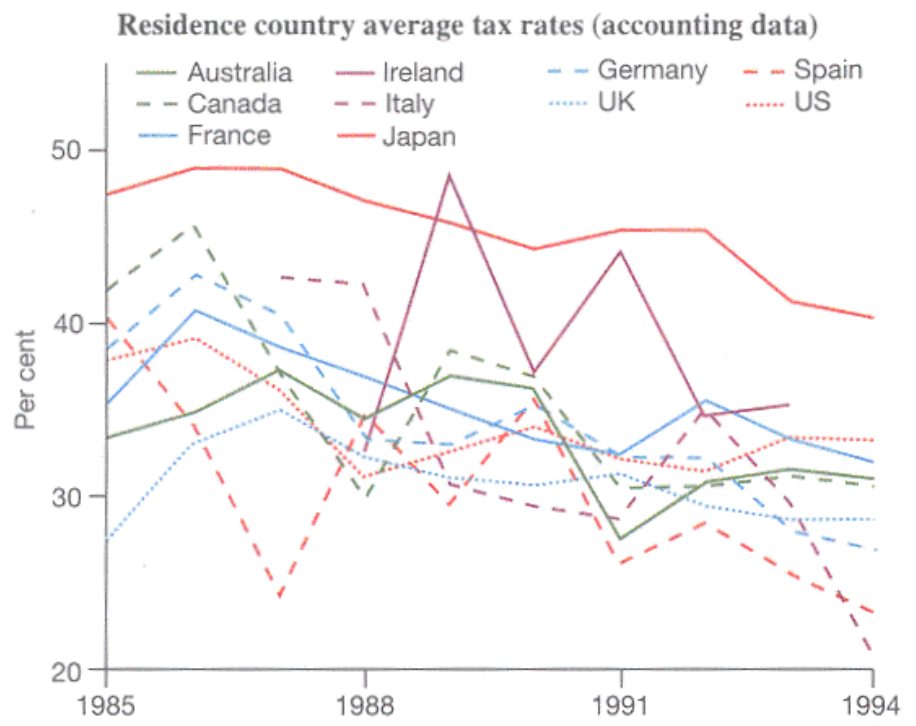

Note: Authors' own calculations. See Appendix A for sources and definition of the average tax rate. The Canadian, Irish, Italian and Spanish rates are estimated from very small samples (see Table A.6 in Appendix A).

mean of the individual residence country standard deviations of the EMTR fell, indicating an increase in the degree of capital export neutrality, on average, in these 10 countries (see Appendix A for the definition of capital export neutrality and the individual country appendices for a discussion of the trends in each country). 
Taxing profits in a changing world

\subsection{Average Tax Rates using Accounting Data}

The final type of tax rate considered in this report is an average tax rate (ATR) that is constructed using accounting data on individual firms. An average tax rate is calculated for each firm as the ratio of the provision for tax to the net pre-tax income. The mean of these individual firm rates is used in each country in each year. The construction of average tax rates from firms' financial statements is briefly discussed in Appendix A and is examined in detail in Collins and Shackelford (1995).

Figure 4.9 shows the average tax rate for each of the 10 countries over time. For four countries - Canada, Ireland, Italy and Spain - there are very little firmlevel data so the estimates of the average tax rates are very imprecise. In Table 4.6, the mean and standard

TABLE 4.6

Average tax rates

\begin{tabular}{l|rrrrrr|r}
\hline & Australia & France & Germany & Japan & UK & US & Ave. \\
\hline \multirow{3}{*}{1985} & 33.5 & 35.6 & 38.8 & 47.5 & 27.8 & 38.0 & 40.0 \\
& 19.5 & 17.8 & 17.0 & 13.9 & 14.5 & 13.0 & 15.2 \\
1986 & 34.9 & 40.9 & 43.0 & 48.9 & 33.2 & 39.3 & 41.6 \\
& 15.5 & 11.0 & 16.0 & 15.1 & 14.2 & 13.7 & 15.1 \\
1987 & 37.3 & 38.7 & 40.5 & 48.9 & 35.1 & 36.2 & 39.8 \\
& 15.8 & 14.6 & 11.6 & 14.6 & 15.5 & 14.7 & 15.6 \\
1988 & 34.5 & 37.0 & 33.4 & 47.1 & 32.3 & 31.2 & 36.2 \\
& 15.2 & 12.4 & 13.6 & 13.5 & 14.5 & 14.6 & 15.5 \\
1989 & 37.0 & 35.2 & 33.1 & 45.8 & 31.1 & 32.7 & 36.1 \\
& 8.4 & 13.1 & 15.4 & 13.2 & 12.9 & 14.5 & 14.7 \\
1990 & 36.2 & 33.4 & 35.4 & 44.2 & 30.7 & 34.1 & 36.0 \\
& 11.9 & 14.9 & 16.3 & 13.3 & 13.2 & 12.6 & 14.2 \\
1991 & 27.6 & 32.5 & 32.1 & 45.4 & 31.3 & 32.2 & 34.8 \\
& 16.6 & 15.0 & 16.4 & 12.5 & 15.1 & 14.2 & 15.4 \\
1992 & 30.8 & 35.7 & 32.3 & 45.3 & 29.5 & 31.5 & 34.2 \\
& 15.6 & 14.3 & 18.0 & 14.1 & 15.7 & 14.4 & 15.9 \\
1993 & 31.6 & 33.4 & 28.2 & 41.3 & 28.7 & 33.4 & 33.6 \\
& 15.0 & 14.3 & 17.1 & 16.1 & 14.0 & 14.8 & 15.6 \\
1994 & 31.0 & 32.0 & 27.1 & 40.3 & 28.7 & 33.3 & 32.6 \\
& 15.0 & 14.8 & 15.1 & 14.2 & 12.4 & 12.8 & 13.8 \\
\hline
\end{tabular}

Note: The overall average given in the final column is the average across all firms in the six countries. See Appendix A for definition and interpretation of average tax rate. 
deviation of the individual ATRs is shown for each of the six other countries. The final column shows the overall mean and standard deviation across all firms in those six countries. While the ATR is not directly comparable to any of the effective tax rates (see Appendix A for a discussion of problems in comparability between these measures), it is most similar to the domestic or residence country effective average tax rate. The mean taken across all companies, shown in the final column, has fallen over time, indicating a reduction in the tax rate. The ATR for the six countries follows a slight downward trend. The pattern is more similar to that of the residence country EATR than to that of the domestic EATR. The standard deviation shown here is across firms, not across assets or countries, so cannot be so readily interpreted as an indicator of the neutrality of the tax system. A high level of variation in firm-level tax rates could indicate many things, such as heterogeneity of profitability levels. 


\section{CHAPTER 5 \\ Explaining Tax-Setting Behaviour}

The previous chapter has described trends in several measures of effective and average tax rates. Unlike the statutory tax rate, there is no strong tendency for the effective tax rates to fall over this period. This stability in the effective tax rates is broadly consistent with the revenue figures presented in Chapter 3 . There was some indication of convergence in the statutory tax rates and the domestic EMTR, although not in any of the other measures. This chapter examines the question of how this empirical evidence might help distinguish between the many alternative theoretical models of government tax-setting behaviour.

Much empirical work has looked at the impact of taxation on investment behaviour or other measures of economic activity such as output or growth rates. In general, this literature has assumed that tax rates are exogenous, i.e. that the level at which taxes are set is not influenced by these same indicators of economic performance (and that neither are influenced by some other factor). But governments do not set tax policy in isolation. Clearly, their decisions are affected by the economic environment and expectations about the behaviour of firms. This chapter reviews a selection of the models that are concerned with the tax-setting behaviour of governments with a view to assessing their empirical predictions. Where possible, the data presented in previous chapters are used to distinguish between the viability of the predictions and discuss 
possible ways of conducting more rigorous tests. 21 One of the difficulties is determining what the appropriate measure of tax is to use.

\subsection{Empirical Predictions}

The theoretical literature on the tax-setting behaviour of governments is vast and growing, and it is beyond the scope of this report to provide a comprehensive review. ${ }^{22}$ The discussion here focuses on the literature dealing with non-co-operative tax-setting behaviour, and particularly on that part of the literature that yields empirical predictions.

A central result of the theoretical literature is that in small, open economies there should be no source-based taxation, i.e. no tax levied by the country where the investment takes place. The alternative is a residencebased corporation tax system - a tax levied by the country of residence of the ultimate owners of the capital. Most countries operate a combination of the two, although in general they tend to be more sourcebased than residence-based. 23

\footnotetext{
${ }^{21}$ There is a considerable empirical literature looking at the political economy of tax-setting in the US states and on competition over VAT rates within Europe. There is little empirical work looking at competition over corporate income taxes in an international setting, Ruding Committee (1992) being the most notable.

${ }^{22}$ See Devereux (1996a) for a review of the literature and Keen (1996) for a general discussion of this issue.

${ }^{23}$ In practice, it can be more difficult to operate residence-based corporate income tax systems, largely because of problems in gathering information about the activities of companies located in other jurisdictions. It is more difficult to keep track of the world-wide profits of companies resident in your country than it is to gather information on the profits of those companies that are physically located in your country.
} 
Taxing profits in a changing world

TABLE 5.1

Empirical predictions concerning tax rates

\begin{tabular}{|c|c|}
\hline Proposition & Authors \\
\hline $\begin{array}{l}\text { 1. Source-based capital income taxes should be } \\
\text { set at a lower rate than labour income taxes }\end{array}$ & Bucovetsky and Wilson, 1991 \\
\hline $\begin{array}{l}\text { 2. Source-based capital income taxes should be } \\
\text { set to zero if there are a very large number } \\
\text { of identical countries (or in a small open } \\
\text { economy) }\end{array}$ & $\begin{array}{l}\text { Bucovetsky and Wilson, 1991; } \\
\text { Razin and Sadka, } 1991\end{array}$ \\
\hline $\begin{array}{l}\text { 3. In a small open economy, all capital income } \\
\text { taxes should be set to zero if governments } \\
\text { cannot tax foreign source income }\end{array}$ & Razin and Sadka, 1991 \\
\hline $\begin{array}{l}\text { 4. Small countries should choose lower source- } \\
\text { based capital income tax rates than large } \\
\text { countries }\end{array}$ & $\begin{array}{l}\text { Bucovetsky, 1991; } \\
\text { Wilson, } 1991\end{array}$ \\
\hline $\begin{array}{l}\text { 5. Governments should restrict capital exports, } \\
\text { if foreign source income cannot be taxed, } \\
\text { and tax foreign portfolio investment at a } \\
\text { higher rate than domestic portfolio } \\
\text { investment }\end{array}$ & $\begin{array}{l}\text { Razin and Sadka, 1991; } \\
\text { Gordon and Varian, } 1989\end{array}$ \\
\hline $\begin{array}{l}\text { 6. Countries should set the same source-based } \\
\text { capital income tax rates as a Stackelberg } \\
\text { leader with a credit system }\end{array}$ & Gordon, 1992 \\
\hline $\begin{array}{l}\text { 7. Countries should use a deduction system for } \\
\text { taxing foreign source income }\end{array}$ & Bond and Samuelson, 1989 \\
\hline $\begin{array}{l}\text { 8. Countries should not tax capital income if } \\
\text { they use an exemption or partial credit } \\
\text { system for foreign source income }\end{array}$ & Janeba, 1994 \\
\hline $\begin{array}{l}\text { 9. Countries should subsidise domestic firms if } \\
\text { capital is immobile, but not if capital is } \\
\text { mobile }\end{array}$ & Janeba, 1994 \\
\hline $\begin{array}{l}\text { 10. Domestically owned capital should be } \\
\text { subsidised at a higher rate if it is located in } \\
\text { the home country than if it is located abroad }\end{array}$ & Levinsohn and Slemrod, 1993 \\
\hline
\end{tabular}

Thus many theoretical models assume that countries can only use source-based taxes. Where capital is assumed to be perfectly mobile, and if the country is a price-taker in the world capital market, then the owners of capital will not bear the incidence of a corporate income tax. ${ }^{24}$ An increase in capital taxes will lead to an

\footnotetext{
${ }^{24}$ See, among others, Gordon (1986), Razin and Sadka (1991) and Bucovetsky and Wilson (1991). Other important references in this literature include Oates (1972) and Zodrow and Mieszkowski (1986) who
} 
outflow of capital which will drive up the pre-tax rate of return until the post-tax rate of return is again equal to that in other locations. This means that the incidence of the tax is not on the owners of mobile capital. Instead, as capital flows out of the country, the income of immobile factors of production declines, implying that the burden of capital taxation falls on these immobile factors. A dead-weight loss arises as a result of the lower level of investment in capital, which would be avoided if the immobile factors were taxed directly. Therefore, capital taxes should be zero (see propositions 2 and 3 in Table 5.1) and any revenue that the government requires should be raised from a tax on immobile factors such as labour. From the data discussed above, it is clear that capital taxes are not in fact zero, whichever of the measures of capital taxation is considered. This and other observations have led to numerous models explaining why they might not be zero.

Devereux (1996a) gives a brief summary of some of the main propositions concerning tax rates that appear in the theoretical literature. These are reproduced in Table 5.1, although not all of them are discussed here. Not all of these hypotheses are easily testable. For example, in order to test proposition 9 - that countries should subsidise domestic firms if capital is immobile, but not if capital is mobile - a good measure of the mobility of capital is needed and we need to observe a significant change in the degree of mobility either across countries or over time in order to be able to identify this as the key factor. Propositions such as the one that public goods will be under-provided relative to some optimum level (not shown in the table) are almost impossible to

showed that competition between countries created an incentive to hold tax rates on capital income down. 


\section{Taxing profits in a changing world}

assess empirically. On the other hand, proposition 4 that small, open economies should choose lower sourcebased capital income tax rates than large, closed economies - is more straightforward to test.

A further complication in assessing the empirical support for theoretical predictions is that the literature tends either to assume much simpler tax instruments than are used by governments or to be unclear about the form of tax instrument under consideration. This makes it difficult to determine how to reflect the theoretical concept in a single empirical measure. As discussed in the previous chapters and in Appendix A, different measures of tax might be more or less informative about the impact of corporate taxes on incentives to invest. Thus different measures are needed to examine alternative aspects of tax-setting behaviour under different assumptions. In general, the theoretical literature has focused on competition over statutory or effective marginal tax rates (EMTRs).

One obvious empirical explanation for the basic question of why tax rates have not converged to zero as the world economy has become more integrated is that capital taxes are tending towards zero, but have not reached it yet. However, we would need to be clear about why exactly we have seen them converge over this time period. What has changed? Has capital become significantly more mobile over this period?

\subsection{Country Size and Openness}

In an extension to the standard models, 25 which assume a large number of small countries, Bucovetsky (1991) and Wilson (1991) consider two countries of different

\footnotetext{
${ }^{25}$ Among others, Oates (1972), Zodrow and Mieszkowski (1986) and Razin and Sadka (1991).
} 
TABLE 5.2

Tabulation by size

\begin{tabular}{lrrr}
\hline & $\begin{array}{r}\text { Statutory tax rate } \\
\text { on retentions }\end{array}$ & Source country & Source country \\
& 33.6 & EMTR & EATR \\
\hline Small countries & 13.5 & 11.8 & 26.4 \\
& 47.8 & 41.1 & 6.6 \\
Large countries & 7.6 & 10.0 & 27.3 \\
& & 2.5 \\
\hline
\end{tabular}

Note: Authors' own calculations. See Appendix A for sources and definitions of statutory tax rate, EMTR and EATR. Small countries are Australia, Canada, Ireland and Spain. Large countries are France, Germany, Italy, Japan, the UK and the US. The standard deviation in italics is measured across the country averages.

population sizes, so the assumption that all countries are price-takers is relaxed. Both papers show that the smaller country will choose a lower tax rate than the larger country (proposition 4). This result holds because the small country faces a more elastic supply of capital.

In Table 5.2, the 10 countries considered in this report are divided into four small countries and six large countries. In evaluating this proposition, it is not clear what the appropriate measure of tax is; therefore the means and standard deviations of three tax rates - the statutory tax rate on retentions, the source country EMTR and the source country EATR - are compared. These are calculated as the average for each country over the 16 years The ranking by size is not sensitive to the measure used.

None of the small country means, shown in Table 5.2 , is significantly lower than the large country rates, although the statutory tax rate is quite a bit lower due to the very low Irish rate. This is interesting, as Ireland is perhaps the only genuinely small country of the 10 , so this could simply indicate that we are conducting this

\footnotetext{
${ }^{26}$ Using GDP, investment, number employed, imports or exports as a measure of size, the ranking of countries has not changed significantly over this period; however, the relative sizes may have changed.
} 
Taxing profits in a changing world

TABLE 5.3

Openness indicator

\begin{tabular}{lccccr}
\hline & 1980 & 1985 & 1990 & 1993 & $1980-93$ \\
\hline Australia & 0.39 & 0.45 & 0.40 & 0.46 & 0.42 \\
Canada & 0.61 & 0.71 & 0.74 & 0.92 & 0.71 \\
France & 0.44 & 0.52 & 0.58 & 0.58 & 0.52 \\
Germany & 0.43 & 0.53 & 0.54 & 0.54 & 0.51 \\
Ireland & - & - & - & - & - \\
Italy & 0.42 & 0.46 & 0.44 & 0.51 & 0.44 \\
Japan & 0.16 & 0.19 & 0.17 & 0.17 & 0.17 \\
Spain & 0.18 & 0.33 & 0.45 & 0.54 & 0.35 \\
UK & 0.46 & 0.55 & 0.60 & 0.65 & 0.55 \\
US & 0.18 & 0.20 & 0.26 & 0.29 & 0.22 \\
\hline
\end{tabular}

Source: Authors' own calculations using OECD STAN dataset.

test on the wrong group of countries. This test is, in any case, quite weak because it does not account for other factors that may influence the level of taxation.

A more informative test would be to look at whether the average level of taxes was lower for smaller countries than for larger countries, conditional on all other factors that influenced the level of taxes. ${ }^{27}$ One particular aspect of a country's economic position that might influence the impact of size on its tax-setting behaviour is the openness of the capital and product markets. Thus smaller, more open economies should have lower tax rates. As discussed in Chapter 1, we do not have a good measure of the openness of the capital markets; however, one measure of the openness of product markets is the sum of imports plus exports divided by total output. This indicator is shown in Table

\footnotetext{
${ }^{27}$ We would normally do this by running a regression of tax on the size of the economy and all other factors that might affect the tax rate. If the coefficient of size were significantly positive, then that would indicate support for the hypothesis that smaller countries tend to have lower tax rates. However, there are several difficulties in estimating this coefficient correctly and in determining what policy instrument should be used as the explanatory variable. Carrying out this test is therefore left for future work.
} 
TABLE 5.4

Tabulation by size and openness

\begin{tabular}{l|rr|rr|rr}
\hline & \multicolumn{2}{|c|}{$\begin{array}{c}\text { Statutory tax rate } \\
\text { on retentions }\end{array}$} & \multicolumn{2}{c|}{ Source country } & \multicolumn{2}{c}{ Source country } \\
& Closed & Open & Closed & Open & \multicolumn{2}{c}{ EATR } \\
& 39.5 & 27.7 & 54.8 & 40.7 & 29.1 & 23.7 \\
\hline Small countries & 7.0 & 18.8 & 12.8 & 7.2 & 5.4 & 8.5 \\
& 47.6 & 48.0 & 41.7 & 40.5 & 26.5 & 28.1 \\
Large countries & 5.5 & 10.6 & 12.2 & 10.1 & 3.0 & 2.2 \\
\hline
\end{tabular}

Note: Authors' own calculations. See Appendix A for sources and definitions of statutory tax rate, EMTR and EATR. Small countries are Australia, Canada, Ireland and Spain. Large countries are France, Germany, Italy, Japan, the UK and the US. Closed economies are Australia, Italy, Japan, Spain and the US. Open economies are Canada, France, Germany, Ireland and the UK.

5.3 for the years 1980,1985, 1990 and 1993 and for the average over the 14 years. All countries (except perhaps Japan) experienced an increase in their openness, particularly Canada, which experienced a large increase in openness.

In Table 5.4, the 10 countries considered are divided by size and openness, and the means and standard deviations of the statutory tax rate and the source country ETRs are compared. Looking just at the means first, we see that only using the statutory tax rate do smaller countries have lower tax rates. For both the statutory rate and the source country EMTR, the mean amongst more open economies is lower. However, there is never a statistically significant difference between small and large countries or open and closed economies, due primarily to the high variance of these measures. Again, this is not a very strong test because the 10 countries considered in this report are probably not the most appropriate upon which to conduct this test.

\subsection{A Dominant Capital Exporter}

Several papers consider relaxing the assumption that all countries are price-takers in the world capital market 


\section{Taxing profits in a changing world}

and allow one country to be dominant. One such paper is Gordon (1992) which discusses the case where one country is a dominant capital exporter and operates a credit system (see Appendix A for a definition). In this case, the optimal policy for the capital-importing country is to set the tax rate on inward investment at the same rate as the capital-exporting country taxes domestic investment (proposition 6). This is because, under a credit system, the income earned abroad will be taxed at home but with a credit given for any foreign taxes paid on that income. The effect of reducing tax on inward investment to zero is simply to transfer tax revenue from the capital-importing to the capitalexporting country.

Does the empirical evidence support this hypothesis? Assuming that markets are competitive, the appropriate tax rate to use to analyse this question is the EMTR. The next problem is identifying which country is the dominant capital exporter, or indeed which countries are capital exporters and which are capital importers. As we can see from Tables A.1 and A.2 in Appendix A and the information shown in the individual country appendices, most countries both import and export capital. The US could reasonably be considered a dominant capital exporter over this period in that it represents the largest proportion of inward investment for most countries. However, the importance of total inward FDI to the source country will also have an impact on the importance that is placed on attracting FDI. For three countries (Canada, Ireland and Japan), the US represents more than half of capital imports, and for the others, it represents a large proportion. A further empirical issue is ensuring that the treatment of foreign source income that is observed corresponds to that described by the theory. The US operates a credit system on both interest and dividend income (see 


\section{FIGURE 5.I}

EMTR on investment from the US into other countries

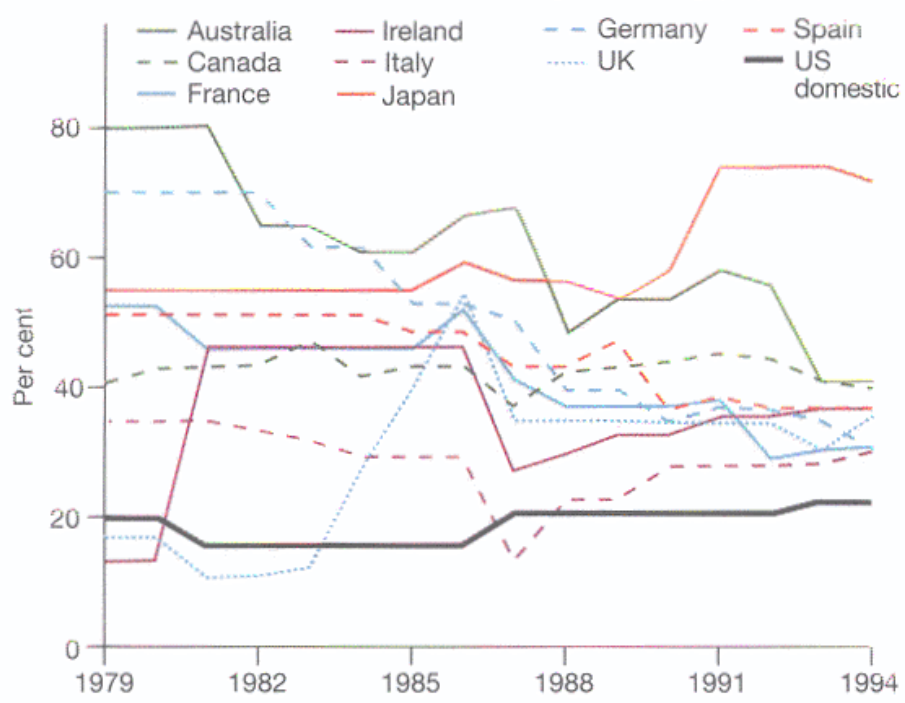

Note. Authors' own calculations. See Appendix A for sources and definition of EMTR. All rates are averaged across finance and assets. Weights used for assets: $28 \%$ buildings, $50 \%$ plant and machinery, $22 \%$ inventories; for parent company source of finance: $55 \%$ retained earnings, $10 \%$ new equity, $35 \%$ debt; for subsidiary source of finance: $33 \%$ retained earnings, $33 \%$ new equity from the parent, $33 \%$ debt from the parent. Inflation is held constant at $3.5 \%$ and the real interest rate at $10 \%$. Economic depreciation rates are $3.61 \%$ for buildings, $12.25 \%$ for plant and machinery and $0 \%$ for inventories.

Appendix B), as specified by theory. However, the definition of the tax base will not usually be the same in the capital-importing and capital-exporting countries. In the case of the US, this is not a concern, as the US attempts to redefine the base for foreign source income to correspond to the US definition. Were this analysis to be conducted using a different country, however, this issue would have to be addressed.

Figure 5.1 shows the EMTR on investment from the US into the other countries and (in bold) the EMTR on domestic investment in the US. All the EMTRs on outward investment, except in a very few cases, are 


\section{Taxing profits in a changing world}

above the domestic rate for US investors. 2.8 The proposition stated that they should be equal, so this figure does not lend direct support.

However, as the source EMTRs are generally above the domestic US EMTR, an alternative explanation could be that all of the other countries have a stronger preference for government expenditure and therefore choose to raise more tax revenue. A more sophisticated model and testing procedure would be needed to investigate this possibility.

A theoretical problem with proposition 6 is that the capital exporter has an incentive to increase its tax rate until there are no capital flows. A deduction system (where tax is due on the foreign source income but the amount of foreign tax paid is deducted from the company's tax liability) would therefore be preferred by the capital exporter and would result in positive capital flows. Thus capital-exporting countries should use a deduction system for taxing foreign source income (proposition 7). ${ }^{29}$ However, as shown in Table B.3 in Appendix B, none of the countries considered operates a deduction system.

Another article that puts forward a prediction based on the treatment of foreign source income is Janeba (1995), which concludes that countries should not tax corporate income if they use an exemption or partial credit system for foreign source income. Table B.3 shows that all the countries considered here operate one

\footnotetext{
${ }^{28}$ The result is similar using alternative weights of subsidiary source of finance - for example, looking only at a subsidiary financed by debt from the parent where all countries considered operate a credit system on the repatriation of interest income.

${ }^{29}$ This result goes back to Richman (1963). A formal model is developed in Feldstein and Hartman (1979) and it is also shown in Bond and Samuelson (1989).

${ }^{30}$ This point is noted by Gordon (1992).
} 
of these two systems, and yet they clearly have non-zero tax rates.

\subsection{Less than Perfectly Mobile Capital}

There are many different forms of imperfect competition that could affect the basic result (propositions 2 and 3 ) that capital income taxes should be zero. In fact, the relaxation of the assumption that all countries are price-takers discussed above implies some form of imperfect competition. In testing propositions of this nature, the EATR would be the appropriate measure to use. However, it is only recently that the theoretical models of tax competition have explicitly allowed for imperfectly competitive product markets 131 It is much more difficult to derive general results in this setting since they usually depend on the form of imperfect competition assumed. Therefore the discussion here is limited to the effect of relaxing the assumption that capital is not perfectly mobile or of allowing firms to earn some economic rents.

The basic theory presented above assumes that capital is perfectly mobile between countries. But if it is not mobile, or at least not perfectly so, what does this imply for the ability of governments to tax it? Janeba (1994) suggests that if capital is immobile, domestic firms should be subsidised (proposition 9), while if capital is mobile, the optimal tax rate is zero. The fact that the domestic EMTR is lower than the source EMTR (compare the final column of Table 4.1 with the first column of Table 4.5) could be interpreted as supporting this hypothesis, if we believed that capital was immobile. This model is interesting in that it is one of

\footnotetext{
${ }^{31} \mathrm{~A}$ recent example is by Haufler and Wooton (1996) who combine models of imperfect competition from the new trade theory with a model of tax competition.
} 


\section{Taxing profits in a changing world}

the few in the literature that suggests that an increase in capital mobility (and thus tax competition) could lead to an increase in tax rates.

In general, when capital is assumed to be immobile, the government can raise revenue from taxes on capital income and will therefore do so. One possibility is that there are both mobile and immobile forms of capital and that governments are limited to the broad instrument of a universal corporate income tax and are prepared to accept the inefficient dead-weight loss associated with taxing mobile capital, in order to collect revenue from the immobile form of capital. We would still expect that, where possible, governments would seek to levy higher taxes on capital that was less mobile.

What empirical observations would be consistent with this hypothesis? If we could observe the degree of mobility of capital and it varied across countries, over time or across different types of asset, then we could see whether variation in mobility was correlated with variation in tax rates. But what do we mean by different degrees of mobility? We could mean that an asset was fairly easy and cheap to move from one country to another. For example, inventories of goods that are consumed world-wide and that are not costly to transport could be considered mobile. However, because an asset such as a building is difficult to move physically does not mean that it is immobile. If investing a unit of currency in constructing a factory in one country will yield the same-quality building as the same amount invested in another country, then we might consider that unit of investment in building to be perfectly mobile. However, if the same amount of investment will yield buildings of different qualities in different countries (i.e. the buildings will yield different rates of return), then we might consider this to represent some degree of immobility. 
This form of immobility means that there are location-specific economic rents to be earned. Each government can, in principle, capture the economic rent that is specific to its location. So, for example, if a firm locating in country A earns a higher rate of rent than if it operated elsewhere because of something specific to that country, then country A would be able to raise tax up to the point where the post-tax rates of return in the two countries were equal, without affecting the firm's investment decision. Taxes on natural resources, such as petroleum, are a classic example of a tax of this form.

One interpretation of the variation in tax rates shown in previous chapters is that countries have different levels of location-specific attributes, allowing them to collect tax on some forms of corporate income. To investigate this hypothesis further, we would have to specify what these attributes were - for example, the possession of mineral deposits or a pool of skilled labour - and examine the degree to which these were correlated with tax rates. However, in general, countries tax all capital income in the same manner so it is difficult to capture location-specific rents.

\subsection{Capital Taxes as an Anti-Avoidance Measure}

An alternative proposition is that capital taxes fulfil some other role. Gordon and MacKie-Mason (1997), among others (see proposition 1), put forward the explanation that capital taxes act as a measure to protect revenue gained from labour taxes. If capital taxes were set to zero, then certain individuals would find ways to shift their earned income into corporate income and thus avoid paying taxes on earned income altogether. In a series of articles, Gordon and co-authors $\frac{32}{\text { cite evidence }}$

\footnotetext{
${ }^{32}$ See, among others, Gordon and Slemrod (1988) and Gordon (1997).
} 
Taxing profits in a changing world

in support of this income-shifting hypothesis. This evidence is based on data from the US and relies on time-series variation in the relative tax incentives to take income in the form of corporate income or labour income. The data presented in this report look only at the taxation of corporate income and therefore provide only half the information needed to test this hypothesis. This would, however, be an area of interesting future research. 


\section{CHAPTER 6 \\ Conclusion}

This report has examined the changes in corporate income taxation over the period from 1979 to 1994 in 10 developed countries. Effective tax rates have not fallen as a result of the rate-reducing, base-broadening reforms. This is consistent with the tax revenue data. There is some indication of convergence in statutory tax rates and domestic effective marginal tax rates, although not in the taxation of cross-border flows of investment income.

The question addressed in Chapter 5 was whether these data conform to the predictions of theoretical models. Four main propositions were discussed: that smaller, more open economies should have lower tax rates than larger, closed economies; that capitalimporting countries should set the tax rate on inward investment at the same rate as the dominant exporting country; that the tax rate should be related to the degree of mobility of capital; and that capital taxes might play some alternate role to raising taxes, such as ensuring that labour income does not escape taxation. No clear empirical evidence to support any of these predictions was found. None of the evidence presented suggested that tax competition is driving tax rates or revenues to zero, or that there has been a significant erosion of the capital tax base.

On the face of it, the evidence appears inconsistent with a tax competition view of the world. However, there could be many reasons for this. The countries examined in this study are perhaps not the ones where we would expect the largest degree of competition. In 
Taxing profits in a changing world

addition, tax systems are becoming more complex and many important changes in the tax treatment of capital have not been reflected in the numbers presented here. It is also worth pointing out that only a subset of the tax competition models and none of the models about tax co-ordination have been considered here. What we have done is to set out some of the data and discuss some of the methodological issues that might help inform both empirical and theoretical research in this area in the future. 


\section{APPENDIX A \\ Methodology}

This appendix gives the precise definition of the data used in this report and describes how the tax systems are modelled. The tax rates and depreciation allowances recorded here are those that were generally available for an investment in manufacturing made by a large firm. Several countries offer lower statutory tax rates or higher allowances for small companies; these are not considered. The firm modelled is one that expects to pay tax in the current and all future years. Tax exhaustion is not considered. Tax changes (even when preannounced) are not anticipated by the investor. Grants, tax incentives and other forms of state aid given at the regional or sectoral level are not considered.

\section{A.1 Statutory Rate}

Three statutory tax rates are presented: the headline rate, the rate applying to retained earnings and the rate applying to distributed profits. The headline rate is the national corporate income tax rate on retained earnings, i.e. those profits that are retained in the company rather than being distributed as dividends. This rate does not include any surcharges or local taxes. In general, this will be the most 'popularly' known rate. In many countries, the tax rates on retained earnings and on distributed profits are the same; however, in some countries they are different. The statutory tax rates on retained earnings and on distributed profits include surcharges and other special taxes that are levied on corporate income at the national level. They also 
Taxing profits in a changing world

include an estimate of corporate income tax levied at the local level. Where, for example, a corporate income tax is levied by states or provinces, we have either tried to construct an average of these rates (weighted by production) or used the rate from a region where a large amount of production takes place. This has not always been possible and, in several cases, the local tax rate is set at the rate given in OECD (1991) in every year due to lack of additional information. Local taxes only include local corporate income taxes. In general, they do not include taxes on property. In many countries, local corporate income taxes are deductible from the national tax and this is taken into account.

The tax rates are based on the rates that apply at the end of each calendar year.

\section{A.2 Foreign Direct Investment Data}

The figures in Table A.1 are calculated using data from the source countries' national accounts. The ratio is calculated as the sum of FDI coming into the source country from each residence country over the period 1982-92, divided by the total amount of FDI from all 10 countries considered over the same period. The figures in Table A.2 are calculated using data from the residence countries' national accounts. The ratio is calculated as the sum of FDI going from the residence country into each of the source countries over the period 1982-92, divided by the total amount of FDI going to all 10 countries considered over the same period.

\section{A.3 Depreciation Allowances}

Depreciation allowances include generally available allowances plus any additional tax credits and first-year allowances. Where there are several alternatives for the 
TABLE A.1

\section{Proportion of inward FDI}

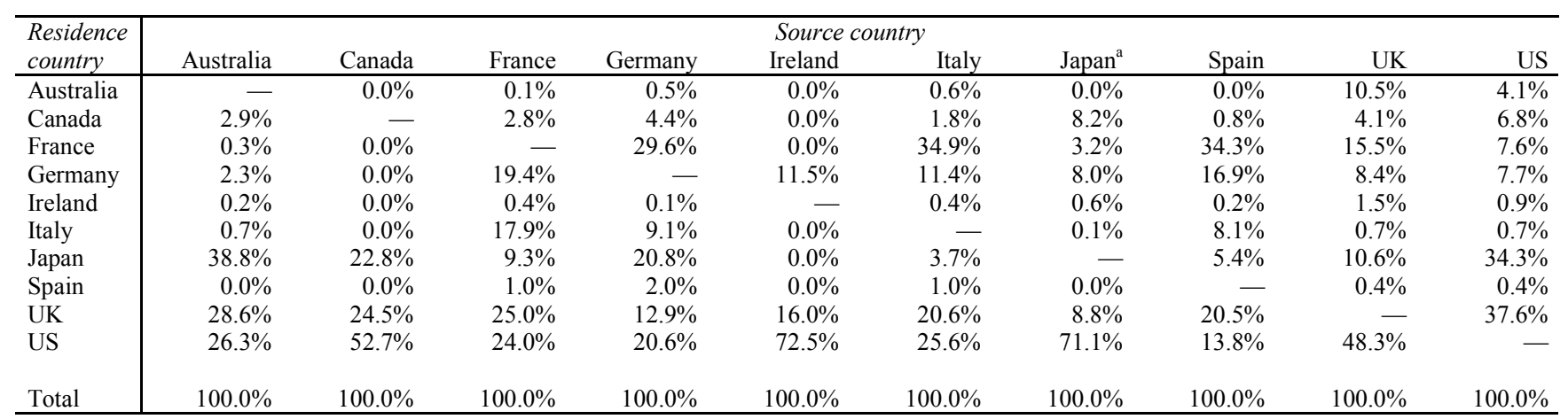

a Japan reports $15.8 \%$ of inward FDI coming from Japan. We set this to zero.

Source: Authors' own calculations from OECD International Direct Investment Statistics 1982-1993 database. 
TABLE A.2

Proportion of outward FDI

\begin{tabular}{|c|c|c|c|c|c|c|c|c|c|c|c|}
\hline \multirow{2}{*}{$\begin{array}{l}\text { Residence } \\
\text { country }\end{array}$} & \multirow[b]{2}{*}{ Australia } & \multicolumn{9}{|c|}{ Source country } & \multirow[b]{2}{*}{ Total } \\
\hline & & Canada & France & Germany & Ireland & Italy & Japan & Spain & UK & US & \\
\hline Australia & - & $5.3 \%$ & $0.2 \%$ & $1.6 \%$ & $0.4 \%$ & $2.3 \%$ & $1.5 \%$ & $0.0 \%$ & $48.4 \%$ & $40.3 \%$ & $100.0 \%$ \\
\hline Canada & $0.0 \%$ & - & $0.0 \%$ & $0.0 \%$ & $0.0 \%$ & $0.0 \%$ & $1.8 \%$ & $0.0 \%$ & $17.1 \%$ & $81.1 \%$ & $100.0 \%$ \\
\hline France & $0.7 \%$ & $3.9 \%$ & - & $11.2 \%$ & $1.0 \%$ & $11.0 \%$ & $0.5 \%$ & $13.5 \%$ & $20.1 \%$ & $38.2 \%$ & $100.0 \%$ \\
\hline $\begin{array}{l}\text { Germany } \\
\text { Ireland }^{\mathrm{a}}\end{array}$ & $1.1 \%$ & $4.8 \%$ & $12.0 \%$ & - & $\begin{array}{r}8.4 \% \\
-\end{array}$ & $6.9 \%$ & $1.9 \%$ & $7.8 \%$ & $15.5 \%$ & $41.6 \%$ & $100.0 \%$ \\
\hline Italy & $0.6 \%$ & $2.2 \%$ & $27.0 \%$ & $11.1 \%$ & $0.3 \%$ & - & $3.6 \%$ & $10.1 \%$ & $16.4 \%$ & $28.7 \%$ & $100.0 \%$ \\
\hline Japan & $0.0 \%$ & $0.0 \%$ & $2.6 \%$ & $3.1 \%$ & $0.3 \%$ & $0.7 \%$ & - & $1.2 \%$ & $14.0 \%$ & $78.1 \%$ & $100.0 \%$ \\
\hline Spain & $0.4 \%$ & $0.0 \%$ & $19.4 \%$ & $6.8 \%$ & $1.6 \%$ & $17.2 \%$ & $0.6 \%$ & - & $28.7 \%$ & $25.5 \%$ & $100.0 \%$ \\
\hline UK & $9.4 \%$ & $6.0 \%$ & $7.7 \%$ & $3.4 \%$ & $2.7 \%$ & $2.8 \%$ & $1.1 \%$ & $4.3 \%$ & - & $62.7 \%$ & $100.0 \%$ \\
\hline US & $6.2 \%$ & $20.0 \%$ & $9.7 \%$ & $12.2 \%$ & $5.9 \%$ & $7.7 \%$ & $5.2 \%$ & $3.7 \%$ & $29.3 \%$ & - & $100.0 \%$ \\
\hline
\end{tabular}

aIreland does not report outward FDI flows.

Source: Authors' own calculations from OECD International Direct Investment Statistics 1982-1993 database. 


\section{Taxing profits in a changing world}

firm to choose from, the most generous form of capital allowance is used. Where a switch from declining balance to straight line is allowed, it is assumed that this is made as soon as the value of the straight-line depreciation exceeds that of the declining balance. Where the depreciation rate is based on the lifetime of the asset, it is assumed that plant and machinery last for eight years and buildings for 25 years 33 None of the countries considered here indexes allowances for inflation.

The measure of the net present value (NPV) of allowances given in the tables in the country appendices is calculated using the formulas given in OECD (1991), using the discount rate for domestic investment financed by retained earnings shown in Table A.3 (the nominal interest rate). A value of unity indicates that the full cost of the investment can be offset immediately.

\section{A.4 Corporation Tax Receipts}

Corporation tax receipts are taxes on corporate income, levied at the national or local level. They include revenue both from the main corporate income tax and from any special taxes levied on the income of particular industries, such as the petroleum taxes levied in the UK and France. They do not include property taxes based on the value of the buildings and region of the country that the businesses are located in. As pointed out in the main text, the figures given are based on receipts of corporate taxes, and so reflect payments of tax rather than tax incidence.

Although items such as property-based taxes are not included, the receipts of special taxes on particular industries are, which will have a variable effect on the

\footnotetext{
${ }^{33}$ See OECD (1991, p. 96).
} 


\section{Taxing profits in a changing world}

proportion of tax raised from companies. For example, the petroleum revenue tax (PRT), levied in the UK since 1978, raised almost as much revenue as corporation tax in 1983-84, but by 1994 raised less than 5 per cent of corporation tax revenue. These particular taxes are revenue from the corporate sector, and their variation over time reflects the changing nature of the source of revenues, which is disguised in the overall figures.

Another issue concerning the receipts data relates to the treatment of the various methods for integrating corporate and personal income taxation. A country that taxes distributed profits at a high rate and gives generous tax relief on dividend income at the personal level will appear to raise more revenue from corporate income tax (and less revenue from personal income tax) than a country that taxes distributed profits at a lower rate and gives less generous tax relief on dividend income at the personal level - although the economic effects of these two systems may be equivalent. The method adopted by the OECD (the source of these data) is to report as corporate tax the total amount of tax collected under various taxes on corporate income, and to make no attempt to impute to personal income tax any relief that is given for tax paid at the corporate level. Of the countries we look at, only the US makes no attempt to alleviate the tax imposed on dividend income, but only the UK actually reports an amount that could be used to estimate the value of the corporate tax imputed to shareholders. Given that these measures to reduce or eliminate the 'double taxation' of dividend income have changed over time in most of the countries looked at, taking this into account could change the impression given of the trends in corporate tax receipts.

However, all of these potential adjustments to the series gloss over the fact that it is not possible to say what proportion of total tax receipts is borne 'by the 
corporate sector'. It is not the case that by adding together corporate income taxes with property taxes on businesses, value added taxes and social security contributions made by employers, and subtracting off that element of corporate tax that is imputed to individuals, we could get an idea of the total tax burden borne by companies. Calculating the incidence of taxation is far more complex than simply adding together payments made at the corporate level. All corporate tax payments must eventually be borne by some individuals, but not all corporate tax payments must be borne by the firm's owners. Some or all of the burden of company taxation may be shifted onto consumers through higher prices, or onto workers through lower wages or employment, rather than reducing the return received by shareholders.

\section{A.5 Effective Tax Rates}

Effective tax rates summarise the impact of the tax system on the required rate of return, taking into account differences in definitions of the tax base as well as differences in tax rates. For example, they reflect differences in capital allowances, relief for inflationary gains on holdings of inventories, the structure of the tax system (for example, whether it is a classical or an imputation system), whether or not capital gains are indexed for inflation, withholding taxes and other aspects of international tax treaties. Differences in economic variables, such as inflation and exchange rates, can also be reflected in effective tax rates.

The effective marginal tax wedge (EMTW) and the effective marginal tax rate (EMTR) summarise the tax burden on the marginal investment. They are commonly used measures for describing the way the tax system affects investors' incentives to invest. The effective 
Taxing profits in a changing world

average tax rate (EATR) presented here is a new measure, recently developed in Devereux and Griffith (1997), which summarises the impact of tax on a rentearning investment.

\section{The effective marginal tax rate (EMTR)}

The effective marginal tax wedge is calculated as in King and Fullerton (1984) and OECD (1991). It is the required pre-tax real rate of return earned on an investment project $(p)$ minus the required post-tax real rate of return earned by the supplier of finance $(s)$. The domestic tax wedge is calculated for each country $(j)$, asset $(l)$, type of finance $(k)$ and year $(t)$. The required pre-tax real rate of return is given by

$p_{j l k t}=\frac{\left(1-A_{j l t}\right)}{\left(1-\tau_{j t}^{r}\right)\left(1+\pi_{j t}\right)}\left[\rho_{j k t}^{\prime}-\pi_{j t}+\delta_{l}\left(1+\pi_{j t}\right)\right]-\delta_{l}$

where $A_{j l t}$ is the net present value of depreciation allowances in country $j$ for asset $l$ in year $t$ (see OECD (1991) for formulas), $\tau_{j t}^{r}$ is the statutory tax rate on retained earnings in country $j$ in year $t, \pi_{j t}$ is the rate of inflation in country $j$ in year $t, \rho_{j k t}^{\prime}$ is the discount rate for an investment in country $j$ financed by $k$ during period $t$, and $\delta_{l}$ is the depreciation rate of asset $l$. The KingFullerton formulas for the discount rates for different sources of finance are given in Table A.3. The post-tax real rate of return is given by

$s_{j t}=\frac{1+i_{j t}}{1+\pi_{j t}}-1$

${ }^{34}$ The treatment of inventories when valued by FIFO is not described here,
but is used in the calculations (see $\operatorname{OECD}(1991$, p. 218)). 
where $i_{j t}$ is the nominal interest rate in country $j$ in year $t$. Note that, in the absence of inflation, this is equal to the nominal interest rate, and at low levels of inflation, it is approximately equal to the nominal interest rate minus inflation. Personal tax rates do not enter in the analysis presented here because the marginal shareholder is considered to be a tax-exempt shareholder (such as a pension fund).

Now consider a cross-border investment. The international tax wedge is calculated for each resident country $(j)$, source country $(n)$, asset $(l)$, type of parent finance $(k)$, type of subsidiary finance $(g)$ and year $(t)$. The pre-tax real rate of return for an international investment is given by

$$
p_{\text {jnklkt }}=\frac{\left(1-A_{n l t}\right)}{\left(1-\tau_{n t}^{r}\right) E_{j n t}\left(1+\pi_{n t}\right)}\left[\rho_{\text {jnkgt }}^{\prime}-\left(1-\delta_{l}\right) E_{j n t}\left(1+\pi_{n t}\right)\right]-\delta_{l}
$$

where all variables are as above and $E_{j n t}$ is the change in the exchange rate between countries $j$ and $n$ during period $t$. The OECD (1991) formulas for the discount rates, $\rho_{\text {jnklkt }}^{\prime}$, for an investment in country $j$, from country $n$, into asset $l$, using parent finance $k$ and subsidiary finance $g$ at time $t$ are given in Table A.3, where $\rho_{j t}=\frac{\left(1-m_{j t}^{i}\right) i_{j t}-z_{j t} \pi_{j t}}{1-z_{j t}}, \gamma_{j t}=\frac{\left(1-m_{j t}^{d}\right)\left(1-\tau_{j t}^{d}\right)}{\left(1-z_{j t}\right)\left(1-c_{j t}\right)\left(1-\tau_{j t}^{r}\right)}, \quad \tau_{j t}^{d}$ is the statutory tax rate on distributed profits in country $j$ in year $t$, marginal personal tax rates are given by $m^{i}$ on interest, $m^{d}$ on dividends and $z$ on capital gains, and $c$ is the imputation rate.

In the calculations presented in this report, purchasing power parity is assumed to hold so the exchange rate is fixed. 
Taxing profits in a changing world

TABLE A.3

Discount rates

\begin{tabular}{|c|c|c|}
\hline $\begin{array}{l}\text { Parent } \\
\text { finance }\end{array}$ & $\begin{array}{l}\text { Subsidiary } \\
\text { finance }\end{array}$ & Discount rate \\
\hline \multicolumn{3}{|l|}{$\begin{array}{l}\text { Domestic } \\
\text { investment }\end{array}$} \\
\hline $\begin{array}{l}\text { Retained } \\
\text { earnings }\end{array}$ & - & $\rho_{j t}$ \\
\hline \multirow[t]{2}{*}{ New equity } & - & $\underline{\rho_{j t}}$ \\
\hline & & $\gamma_{j t}$ \\
\hline Debt & - & $i_{j t}\left(1-\tau_{j t}^{r}\right)$ \\
\hline \multicolumn{3}{|l|}{$\begin{array}{l}\text { International } \\
\text { investment }\end{array}$} \\
\hline $\begin{array}{l}\text { Retained } \\
\text { earnings }\end{array}$ & $\begin{array}{l}\text { Retained } \\
\text { earnings }\end{array}$ & $\rho_{j t}$ \\
\hline \multirow[t]{2}{*}{$\begin{array}{l}\text { Retained } \\
\text { earnings }\end{array}$} & New equity & $\underline{\rho_{j t}+\left(1-E_{j n t}\right) \gamma_{j t} \sigma_{j n t}^{*^{\prime}}}$ \\
\hline & & $\overline{1-\gamma_{j t} \sigma_{j n t}^{* \prime}}$ \\
\hline \multirow[t]{2}{*}{ New equity } & New equity & $\underline{\rho_{j t}+\left(1-E_{j n t}\right) \gamma_{j t} \sigma_{j n t}^{*^{\prime}}}$ \\
\hline & & $\gamma_{j t}\left(1-\sigma_{j n t}^{*^{\prime}}\right)$ \\
\hline \multirow[t]{2}{*}{ Debt } & New equity & $i_{j t}\left(1-\tau_{j t}^{r}\right)+\left(1-E_{j n t}\right) \gamma_{j t} \sigma_{j n t}^{*^{\prime}}$ \\
\hline & & $\left(1-\sigma_{j n t}^{* \prime}\right)$ \\
\hline \multirow[t]{2}{*}{$\begin{array}{l}\text { Retained } \\
\text { earnings }\end{array}$} & Debt & $\rho_{j t}+\left(1-E_{j n t}\right) \gamma_{j t} \sigma_{j n t}^{* \prime}+E_{j n t} i_{n t} \gamma_{j t} \omega_{j n t}^{* d}$ \\
\hline & & $\overline{1-\gamma_{j t} \sigma_{j n t}^{* \prime}}$ \\
\hline \multirow[t]{2}{*}{ New equity } & Debt & $\underline{\rho_{j t}+\left(1-E_{j n t}\right) \gamma_{j t} \sigma_{j n t}^{* \prime}+E_{j n t} i_{n t} \gamma_{j t} \omega_{j n t}^{* d}}$ \\
\hline & & $\overline{\gamma_{j t}\left(1-\sigma_{j n t}^{*^{\prime}}\right)}$ \\
\hline \multirow[t]{2}{*}{ Debt } & Debt & $i_{j t}\left(1-\tau_{j t}^{r}\right)+\left(1-E_{j n t}\right) \sigma_{j n t}^{*^{\prime}}+E_{j n t} i_{n t} \omega_{j n t}^{* d}$ \\
\hline & & $1-\sigma_{j n t}^{* \prime}$ \\
\hline
\end{tabular}

Source: OECD, 1991.

Because we consider the marginal shareholder to be tax-exempt, we set $m^{i}=0, m^{d}=0$ and $z=0$. The effective total tax charge on interest payments by the subsidiary to the parent, $\omega_{j n t}^{* d}$, and the effective total tax charge on dividend payments by the subsidiary to the 
TABLE A.4

Treatment of foreign source income

\begin{tabular}{l|l|l}
\hline & Dividend $\sigma_{j n t}^{*^{\prime}}$ & Interest $\omega_{j n t}^{* d}$ \\
\hline Exempt & $\omega_{j n t}^{d}-c_{j n t}+\tau_{n t}^{d}-\tau_{n t}^{r}$ & $\omega_{j n t}^{r}$ \\
Credit & $\max \left\{\frac{\tau_{j t}^{r}-\tau_{n t}^{d}}{1-\tau_{n t}^{d}}, \omega_{j n t}^{d}-c_{j n t}\right\}+\tau_{n t}^{d}-\tau_{n t}^{r}$ & $\max \left\{\tau_{j t}^{r}, \omega_{j n t}^{r}\right\}$ \\
Deduction & $\tau_{j t}^{r}\left(1-\omega_{j n t}^{d}-c_{j n t}\right)+\omega_{j n t}^{d}-c_{j n t}+\tau_{n t}^{d}-\tau_{n t}^{r}$ & $\tau_{j t}^{r}\left(1-\omega_{j n t}^{r}\right)+\omega_{j n t}^{r}$ \\
\hline
\end{tabular}

parent, $\sigma_{j n t}^{* \prime}$, are given in Table A.4, where $\omega_{j n t}^{r}$ is the withholding tax rate on interest payments, $\omega_{j n t}^{d}$ is the withholding tax rate on dividend payments and $c_{j n t}$ is the imputation credit available on dividend payments.

In the body of the text, we focus on the tax-exclusive effective marginal tax rate, $\frac{p_{j n k g t}-s_{j t}}{s_{j t}}$. The weights used in all cases, unless otherwise stated, are as in Table A.5. A constant inflation rate of 3.5 per cent and real interest rate of 10 per cent have been used in all countries in all years unless otherwise specified. The effective marginal tax rates on international investment are weighted by the average FDI flows shown in Tables A.1 and A.2.

TABLE A.5

Finance and asset weights, and economic depreciation rates

\begin{tabular}{llll}
\hline $\begin{array}{l}\text { Parent } \\
\text { finance weights }\end{array}$ & $\begin{array}{l}\text { Subsidiary } \\
\text { finance weights }\end{array}$ & Asset weights & $\begin{array}{l}\text { Economic } \\
\text { depreciation rates }\end{array}$ \\
\hline $\begin{array}{l}55 \% \text { retained } \\
\text { earnings }\end{array}$ & $\begin{array}{l}33 \% \text { retained } \\
\text { earnings }\end{array}$ & $\begin{array}{l}28 \% \text { industrial } \\
\text { buildings }\end{array}$ & $\begin{array}{l}\text { Industrial } \\
\text { buildings at } \\
3.61 \%\end{array}$ \\
$10 \%$ new equity & $\begin{array}{l}33 \% \text { new equity } \\
\text { from parent }\end{array}$ & $\begin{array}{l}50 \% \text { industrial } \\
\text { plant and }\end{array}$ & $\begin{array}{l}\text { Industrial plant } \\
\text { and machinery at } \\
\text { machinery }\end{array}$ \\
& $\begin{array}{l}33 \% \text { debt from } \\
\text { parent }\end{array}$ & $\begin{array}{l}12.25 \% \text { inventories } \\
\text { Inventories at } 0 \%\end{array}$ \\
\hline
\end{tabular}

Source: OECD, 1991. 
Taxing profits in a changing world

\section{The effective average tax rate (EATR)}

The measure of the EATR considered is on an investment project with a fixed pre-tax real rate of return (net of depreciation), $p$, which results in a positive net present value of economic rent. Let $R$ denote the present value of the economic rent, $V$ the present value of the income stream and $C$ the cost of the project, and let $*$ denote 'in the absence of tax'. The level of rent in the absence of tax is given by $R^{*}=V^{*}-C^{*}$ and in the presence of tax is given by $R=V-C$. The effective average tax rate is calculated for each resident country $(j)$, source country $(n)$, asset $(l)$, type of finance $(k)$ and year $(t)$ and can be defined as

$$
\operatorname{EATR}=\frac{V^{*}-V}{V^{*}}=1-\frac{\left(\rho_{j k t}^{*}+\delta_{l}-\pi_{j t}\right)}{\left(\rho_{j k t}^{\prime}+\delta_{l}-\pi_{j t}\right)}\left[1-\tau_{j t}^{r}+\frac{A_{j l t}\left(\rho_{j k t}^{*}+\delta_{l}-\pi_{j t}\right)}{\left(p+\delta_{l}\right)}\right]
$$

where all variables are as defined above with similar notation. Note that the discount rate in the absence of tax, $\rho^{*}$, is the real interest rate. The EATR can be generalised to international investment in a similar manner to the EMTR. See Devereux and Griffith (1997) for development and discussion of this measure. The effective average tax rates on international investment are weighted by the average FDI flows shown in Tables A.1 and A.2.

\section{A.6 Average Tax Rates (Accounting Data)}

An alternative measure of the average tax rate (ATR) can be constructed using firm-level accounting data. See Collins and Shackelford (1995) for a thorough discussion of this method for constructing average tax rates. This average tax rate is a very different measure from the ones constructed above. It is a measure of the 
Methodology

TABLE A.6

Sample size from Global Vantage

\begin{tabular}{lrrrrrrrrrr}
\hline & Aus & Can & Fra & Ger & Ire & Italy & Japan & Spain & UK & US \\
\hline 1985 & 8 & 2 & 6 & 7 & - & - & 64 & 2 & 18 & 82 \\
1986 & 9 & 3 & 11 & 11 & - & - & 70 & 2 & 28 & 101 \\
1987 & 14 & 9 & 20 & 14 & - & 3 & 77 & 5 & 52 & 118 \\
1988 & 18 & 9 & 27 & 19 & 3 & 2 & 87 & 6 & 73 & 122 \\
1989 & 17 & 5 & 33 & 27 & 3 & 5 & 97 & 7 & 80 & 137 \\
1990 & 17 & 7 & 35 & 29 & 4 & 5 & 104 & 9 & 87 & 141 \\
1991 & 20 & 9 & 33 & 22 & 3 & 5 & 94 & 7 & 90 & 152 \\
1992 & 27 & 7 & 32 & 24 & 4 & 3 & 84 & 7 & 93 & 158 \\
1993 & 28 & 7 & 29 & 26 & 4 & 3 & 85 & 6 & 87 & 163 \\
1994 & 23 & 4 & 25 & 24 & - & 2 & 47 & 4 & 73 & 161 \\
\hline \multicolumn{7}{l}{ Key: Aus = Australia; Can = Canada; Fra = France; Ger = Germany; Ire = Ireland. }
\end{tabular}

Key: Aus $=$ Australia $;$ Can $=$ Canada $;$ Fra $=$ France $;$ Ger $=$ Germany; Ire $=$ Ireland.

tax rate a firm is currently paying on the returns from all of its past investment projects. This will include projects of varying age, duration, asset composition and financing. It will also reflect complexities of the tax system that are not captured by the effective tax rates, such as whether or not a firm is tax-exhausted (that is, whether it has any tax liability, after taking into account its allowances), as well as the more complex nature of corporate relationships than the stylised one-subsidiary example used in calculating the effective tax rates presented in previous sections.

The measure presented here is calculated using firmlevel data from Compustat's Global Vantage dataset. A tax rate is calculated for each firm as the ratio of 'provision for tax' to 'net pre-tax income'. Table A.6 shows the number of firms in each country-year from which the tax rates are estimated. Due to the small sample sizes in Canada, Ireland, Italy and Spain, the average tax rates for these countries are not discussed in the main body of the report. The truncated mean 35 of

\footnotetext{
${ }^{35}$ The mean is calculated from the firms whose tax rate falls between 0 and $70 \%$. This yields a similar estimate to the median (see Collins and Shackelford (1995)).
} 


\section{Taxing profits in a changing world}

these tax rates is shown in Figure 4.9 (see the country appendices for the truncated mean and standard deviation for each country in each year).

There are also several problems with using accounting data to make cross-country comparisons. One problem arises from differences in accounting definitions. Another issue is the timing of tax payments in the numerator, which will differ substantially across countries. Some countries, such as Germany, operate a one-book system where accounting profits are the same as taxable profits, while other countries - the UK and the US, for example — operate two-book systems where they are not the same. Neither of these is the same as a true measure of economic profit, which is what we would ideally like to measure. These differences may vary systematically across countries, making direct comparison difficult.

\section{A.7 Interpretation of Tax Rates}

While the effective marginal and average tax rate measures are similar in nature, care should be taken in making comparisons between them. The discussion of how these tax rates have changed over time or across countries assumes a model of investment in which the tax rate has a linear effect, so that a 1 percentage point change in the tax rate will have the same impact on the level of investment, regardless of the absolute level of the tax rate. It is possible to use the same measure to compare alternative types of investment (for example, the EMTR on different assets or between different locations). However, making inferences from a comparison of the levels of the two effective tax rates is difficult. This is because the impact of a 1 percentage point change in the EMTR may be very different from a 1 percentage point change in the EATR. In order to 
make such comparisons, it is necessary to have econometric evidence on the relative impact on investment of these two different measures of the tax system. ${ }^{36}$ While the levels of the EMTR and EATR cannot easily be compared, it is possible to use them as alternative measures to examine how the tax system has changed over time or varies between countries and compare the results.

Comparison between the EATR and ATR is also difficult, since they do not measure the same thing. The numerator in the EATR is the change in the present value of one specific investment project due to the presence of the tax system, while the denominator is the net present value of the project in the absence of tax. This cannot be measured using accounting data. The ATR, constructed using firm-level accounting data, is the tax paid by the firm on its full range of investment projects, divided by net income. This will include revenue from both past and current investments. The ATR will also mainly apply to income from domestic investments, as for most firms this constitutes the bulk of their earnings. In this sense, it is more comparable to the domestic EATR than any other measure. However, it will also reflect the tax paid on income from foreign investments by domestic firms, making it in some part comparable to the residence country EATR, albeit with very different weights. It is also important to note that the standard deviations on the EATR and the ATR are measuring quite different things. The standard deviation on the EATR is across different countries, while the standard deviation on the ATR is across different firms. Thus the former can be used as an indicator of capital export neutrality, while the latter cannot.

\footnotetext{
${ }^{36}$ See Devereux and Griffith (1996) for some evidence on this question.
} 
Taxing profits in a changing world

Two concepts used in the discussion of neutrality between different tax systems are capital import neutrality (CIN) and capital export neutrality (CEN). Capital export neutrality is said to exist when an investor faces the same tax rate on income from capital, regardless of the location of the investment. One measure of the degree to which CEN is achieved is the standard deviation on the effective tax rates for outward investment - small standard deviations imply that the treatments of different countries are relatively similar, and if the standard deviation falls over time, the degree of CEN has increased. Capital import neutrality exists when investors face the same tax rate on income earned on an investment, regardless of their country of residence. One measure of the degree to which $\mathrm{CIN}$ is achieved is the standard deviations on the effective tax rates for inward investment.

\footnotetext{
${ }^{37}$ See OECD (1991) for a thorough discussion of the conditions for CIN and $\mathrm{CEN}$ and their implications for the adoption of credit and exemption systems for the treatment of foreign source income. See Devereux and Pearson (1995) for a discussion of the economic efficiency implications of CEN and CIN.
} 


\section{APPENDIX B \\ Description of Country Appendices}

The following appendices give details of the taxation of corporate income in each of the 10 countries considered over the period 1979-94. The definitions of the variables and the methodology used are given in Appendix A. The main sources for information about statutory tax rates, depreciation allowances and the structure of the tax systems were the Price Waterhouse Doing Business in ... guides and the Price Waterhouse Corporation Tax Summary. Some information was also taken from the KPMG Tax Notes, the International Bureau for Fiscal Documentation (IBFD) Annual Report, OECD (1991 - Taxing Profits in a Global Economy) and various other publications dealing with specific countries. The information on inflation and interest rates was taken from OECD Economic Outlook. The foreign direct investment and tax revenue statistics are from the OECD databases. The firm-level accounting data are taken from Compustat's Global Vantage database.

\section{B.1 Information in Tables in Country Appendices}

The tables in each country appendix (Appendices C-L) show the following information.

\section{First table: tax rates and NPV of allowances}

The first table shows statutory tax rates, the net present value (NPV) of depreciation allowances and tax receipts. There are three statutory tax rates given: the headline rate, the statutory rate on retained earnings and 
Taxing profits in a changing world

the statutory rate on distributed profits. The headline rate is the corporate income tax rate levied on retained profits at the national level. The statutory rates on retained and on distributed profits (the latter given in parentheses) include surcharges, special rates for manufacturing firms and local corporate income taxes. The depreciation allowances given are the net present value of the flow of allowances over time, independently of the corporate tax rate. A value of unity indicates that the full amount of the investment can be offset immediately. A fixed discount rate of 10 per cent has been used in making these calculations. The information on corporate tax receipts is taken from OECD Revenue Statistics and includes revenue from the national and local corporate income taxes (see Appendix A for a discussion of how these statistics are compiled).

\section{Second table: domestic effective marginal tax wedge}

The second table gives the tax wedge on a domestic investment. It represents the difference between the rate of return earned by companies on their investment before corporate tax and the post-tax return received by the companies' shareholders. We have assumed that the marginal shareholder is tax-exempt. The tax wedges are weighted averages across types of finance and across assets. The weights used are shown in Table A.5. Inflation and the real interest rate are held constant at 3.5 per cent and 10 per cent respectively.

\section{Third table: effective tax rates}

The third table presents information on the effective tax rates for inward and outward investments holding inflation, interest rates and exchange rates constant across countries and over time. The first and second 
columns show the domestic EMTR and EATR for comparative purposes. The effective marginal tax rate is the effective rate of tax that applies to an investment project that just earns the required post-tax rate of return; the effective average tax rate is the rate of tax that applies to an investment project that earns a real rate of return of 40 per cent in the absence of tax. The levels of the marginal and average tax rates are not directly comparable, but the overall trends are. The third and fourth columns show the EMTR and EATR for inward investment. The fifth and sixth columns show the EMTR and EATR for outward investment. The final column shows the average tax rate calculated using accounting data from Compustat's Global Vantage database, where the tax rate for each firm is defined as the ratio of provision for tax to net pre-tax income and the median of those tax rates is presented here. See Appendix A for more details on the sources of these data.

\section{B.2 Structure of Tax Systems}

There are some elements of the tax systems which remain relatively unchanged over time, notably the treatment of inventories, the method of integrating corporate and personal taxation for the treatment of dividend income, and the treatment of foreign source income.

The method by which firms are allowed to value inventories will affect their taxable profits (and therefore tax rate) in the presence of inflation. There are at least two commonly used methods - FIFO (first in, first out) and LIFO (last in, first out). During periods of high inflation, FIFO will value profits higher than LIFO and thus increase the effective tax rate. In many countries, firms can choose which method they want to 
Taxing profits in a changing world

TABLE B. 1

Valuation method for inventories

\begin{tabular}{ll}
\hline Australia & FIFO \\
Canada & FIFO \\
France & FIFO \\
Germany & LIFO \\
Ireland & FIFO \\
Italy & LIFO \\
Japan & LIFO \\
Spain & FIFO \\
UK & FIFO \\
US & LIFO \\
\hline
\end{tabular}

use. Firms may want to use FIFO to increase reported profits (particularly in one-book countries), while for tax reasons they would prefer to use LIFO. We assume that firms use LIFO unless this is explicitly disallowed. Table B. 1 shows the systems used by the 10 countries.

Income from corporate profits can be the subject of taxation at two levels - the corporate level and the personal income tax level. There are a variety of approaches that countries have adopted to try to alleviate this 'double' taxation through the integration of the personal and corporate income tax systems. Table B.2 summarises these approaches into several categories: split-rate systems, imputation systems, classical systems and types of shareholder relief. Under a split-rate system, there are two different statutory corporate tax rates - one that applies to retained earnings and the other to distributed earnings. The lower rate on distributed profits acts to compensate, usually only partially, for the personal income tax levied on the dividend income. An imputation system is one in which some portion of corporate income taxes paid on distributed profits can be offset against the individual personal income tax liability. Under some systems, this comes in the form of a credit which can be refunded if, for example, the individual is tax-exempt. The rates of 
TABLE B. 2

Method of integrating corporate and personal income taxes

\begin{tabular}{|c|c|}
\hline Australia & $\begin{array}{l}\text { Split rate in operation until } 1987 \text {. Dividend imputation system } \\
\text { introduced applying to dividends paid after } 30 \text { June } 1987 . \\
\text { Shareholders entitled to a rebate of corporate tax paid on dividends. } \\
\text { The method for franking dividends is effectively the same as } \\
\text { extending imputation treatment to retained earnings. We have } \\
\text { assumed that this can be done without limit, so all capital gains can } \\
\text { be dissipated. This means that the discount rate used for retained } \\
\text { earnings is the same as that used for new equity (after 1987) in the } \\
\text { figures calculated in Appendix C. }\end{array}$ \\
\hline Canada & $\begin{array}{l}\text { Imputation system, with non-refundable dividend tax credit. This is } \\
\text { modelled as a dividend relief scheme, setting the imputation rate to } \\
\text { zero and adjusting the statutory rate on distributed profits. }\end{array}$ \\
\hline France & $\begin{array}{l}\text { Imputation system which gives shareholders a credit of } 33 \text { per cent } \\
\text { (called the avoir fiscal). }\end{array}$ \\
\hline Germany & $\begin{array}{l}\text { Operates a split-rate system and an imputation system. The credit is } \\
36 \text { per cent until } 1994 \text {, when it drops to } 30 \text { per cent. }\end{array}$ \\
\hline Ireland & Imputation system. The credit is 30 per cent. \\
\hline Italy & $\begin{array}{l}\text { Imputation system. The credit is } 25 \text { per cent until } 1983 \text { and } 36 \text { per } \\
\text { cent thereafter. }\end{array}$ \\
\hline Japan & $\begin{array}{l}\text { Split-rate system until 1990, partial shareholder relief system } \\
\text { thereafter. }\end{array}$ \\
\hline Spain & $\begin{array}{l}\text { Dividend tax credit given but it is not refundable so is included by } \\
\text { reducing the rate of personal tax on dividend income. }\end{array}$ \\
\hline UK & $\begin{array}{l}\text { Imputation system. The credit is } 30 \text { per cent until } 1985,29 \text { per cent } \\
\text { in } 1986,27 \text { per cent in } 1987,25 \text { per cent from } 1988 \text { to } 1992 \text {, and } 20 \\
\text { per cent from } 1993 \text {. }\end{array}$ \\
\hline US & Classical system. \\
\hline
\end{tabular}

imputation given in Table B.2 are expressed as a share of the gross dividend (i.e. the cash dividend plus its associated tax credit). A classical system makes no allowance for double taxation, so that dividend income is subject to corporate income tax and taxed again as personal income.

The treatment of income from foreign sources, in the form of dividend or interest income, does not change during the period, except in a very few cases, as can be seen from Table B.3. The most common methods of dealing with foreign income are the credit method and the exemption method. The former grants a credit for foreign taxes paid by the subsidiary against the tax that 
Taxing profits in a changing world

TABLE B.3

Treatment of foreign source income

\begin{tabular}{lll}
\hline & Interest & Dividends \\
\hline Australia & Credit & Exempt \\
Canada & Credit & Exempt ${ }^{\mathrm{a}}$ \\
France & Credit & Exempt (95\%) \\
Germany & Credit & Exempt \\
Ireland & Credit $^{\mathrm{b}}$ & Credit \\
Italy & Credit $_{\text {Japan }}^{\text {Credit }}$ & Credit \\
Spain & Credit & Credit \\
UK & Credit & Credit \\
US & Credit & Credit \\
\hline
\end{tabular}

${ }^{a}$ Except for income from Australia prior to 1981, for which a credit system operated. ${ }^{b}$ Except for income from Australia prior to 1984 and Spain prior to 1994, for which a deduction system operated.

would have been owed on that income by the parent had the investment been wholly domestic. The credit method has several variations, according to whether foreign source income is considered on a country-bycountry basis or a world-wide basis, and according to different classes of income, such as passive or active. However, as we consider only active investments into a single country, these are effectively the same. The exemption method exempts foreign income in the hands of the parent, so that the tax paid in the country that is the source of the profits, the withholding tax paid when the subsidiary transfers the income to the parent, and personal taxes owed by investors in the parent company are the only taxes levied. One other alternative modelled here is a deduction system, which allows the tax paid on foreign source income to be deducted from the tax base when calculating the payment owed in the residence country. 


\section{APPENDIX C \\ Australia}

The statutory tax rate on corporate income remained constant in Australia throughout the first half of the 1980 s, but as part of the introduction of an imputation system in 1987 , the rate was dramatically reduced in 1988, from 50 per cent to 39 per cent, and further reduced to 33 per cent in 1993. Depreciation allowances have remained generous for plant and machinery, while there has been an increase in the value of allowances given for industrial buildings. These two effects in combination have led to a significant fall in the average

TABLE C.1

Australian tax rates and NPV of allowances

\begin{tabular}{|c|c|c|c|c|c|c|}
\hline & $\begin{array}{r}\text { Headline } \\
\text { rate }\end{array}$ & $\begin{array}{r}\text { Statutory } \\
\text { rate }^{a}\end{array}$ & $\begin{array}{r}N P V \text { of } \\
\text { allowances } \\
\text { (buildings) }\end{array}$ & $\begin{array}{r}N P V \text { of } \\
\text { allowances } \\
\text { (plant and } \\
\text { machinery) }\end{array}$ & $\begin{array}{l}C T \\
\text { as a } \\
\% \text { of } \\
G D P\end{array}$ & $\begin{array}{r}C T \text { as a } \\
\% \text { of } \\
\text { total } \\
\text { tax } \\
\text { receipts }\end{array}$ \\
\hline 1979 & 50.0 & $50.0(46.0)$ & 0.00 & 0.71 & 3.0 & 10.3 \\
\hline 1980 & 50.0 & $50.0(46.0)$ & 0.00 & 0.71 & 3.5 & 12.2 \\
\hline 1981 & 50.0 & $50.0(46.0)$ & 0.00 & 0.71 & 3.4 & 11.4 \\
\hline 1982 & 50.0 & $50.0(46.0)$ & 0.20 & 0.78 & 3.0 & 10.1 \\
\hline 1983 & 50.0 & $50.0(46.0)$ & 0.20 & 0.78 & 2.6 & 8.9 \\
\hline 1984 & 50.0 & $50.0(46.0)$ & 0.32 & 0.78 & 2.8 & 9.3 \\
\hline 1985 & 50.0 & $50.0(46.0)$ & 0.32 & 0.78 & 2.8 & 9.3 \\
\hline 1986 & 50.0 & $50.0(49.0)$ & 0.32 & 0.78 & 2.8 & 9.1 \\
\hline 1987 & 50.0 & $50.0(49.0)$ & 0.20 & 0.78 & 3.2 & 10.3 \\
\hline 1988 & 39.0 & $39.0(39.0)$ & 0.20 & 0.78 & 3.3 & 10.7 \\
\hline 1989 & 39.0 & $39.0(39.0)$ & 0.20 & 0.71 & 3.9 & 12.7 \\
\hline 1990 & 39.0 & $39.0(39.0)$ & 0.20 & 0.71 & 4.4 & 14.1 \\
\hline 1991 & 39.0 & $39.0(39.0)$ & 0.20 & 0.64 & 4.2 & 14.4 \\
\hline 1992 & 39.0 & $39.0(39.0)$ & 0.32 & 0.64 & 4.1 & 14.4 \\
\hline 1993 & 33.0 & $33.0(33.0)$ & 0.32 & 0.73 & 3.7 & 12.8 \\
\hline 1994 & 33.0 & $33.0(33.0)$ & 0.32 & 0.73 & 4.2 & 14.1 \\
\hline
\end{tabular}


Taxing profits in a changing world

TABLE C.2

Australian domestic effective marginal tax wedge

\begin{tabular}{l|rrr|rrr|r}
\hline & Buildings & $\begin{array}{r}\text { Plant and } \\
\text { machinery }\end{array}$ & Inventory & $\begin{array}{r}\text { Retained } \\
\text { earnings }\end{array}$ & $\begin{array}{r}\text { New } \\
\text { equity }\end{array}$ & Debt & Average \\
& 1 & 2 & 3 & 4 & 5 & 6 & 7 \\
\hline 1979 & 7.6 & 1.7 & 7.4 & 8.2 & 8.2 & -2.0 & 4.6 \\
1980 & 7.6 & 1.7 & 7.4 & 8.2 & 8.2 & -2.0 & 4.6 \\
1981 & 7.6 & 1.7 & 7.4 & 8.2 & 8.2 & -2.0 & 4.6 \\
1982 & 5.0 & 0.5 & 7.4 & 6.7 & 6.7 & -3.0 & 3.3 \\
1983 & 5.0 & 0.5 & 7.4 & 6.7 & 6.7 & -3.0 & 3.3 \\
1984 & 3.7 & 0.5 & 7.4 & 6.2 & 6.2 & -3.3 & 2.9 \\
1985 & 3.7 & 0.5 & 7.4 & 6.2 & 6.2 & -3.3 & 2.9 \\
1986 & 4.6 & 1.2 & 8.4 & 7.5 & 7.5 & -3.3 & 3.7 \\
1987 & 5.9 & 1.2 & 8.4 & 7.9 & 7.9 & -3.0 & 4.1 \\
1988 & 4.0 & 0.7 & 5.6 & 5.4 & 5.4 & -2.2 & 2.7 \\
1989 & 4.0 & 1.6 & 5.6 & 5.9 & 5.9 & -2.0 & 3.1 \\
1990 & 4.0 & 1.6 & 5.6 & 5.9 & 5.9 & -2.0 & 3.1 \\
1991 & 4.0 & 2.5 & 5.6 & 6.4 & 6.4 & -1.6 & 3.6 \\
1992 & 3.1 & 2.5 & 5.6 & 6.1 & 6.1 & -1.8 & 3.3 \\
1993 & 2.4 & 1.0 & 4.3 & 4.2 & 4.2 & -1.8 & 2.1 \\
1994 & 2.4 & 1.0 & 4.3 & 4.2 & 4.2 & -1.8 & 2.1 \\
\hline
\end{tabular}

Notes: Columns 1-3 are weighted averages across types of finance; columns 4-6 are weighted averages across assets; column 7 is a weighted average across both finance and assets. Weights used are: $28 \%$ buildings, $50 \%$ plant and machinery, $22 \%$ inventories; $55 \%$ retained earnings, $10 \%$ new equity, 35\% debt. Inflation and the real interest rate are held constant at 3.5\% and $10 \%$ respectively. See Appendix A for definition and interpretation of variables.

tax wedge (see final column, Table C.2). Corporate tax receipts have increased as a proportion of Australia's GDP, although they show some cyclical fluctuations, and the same is true for the proportion of total tax revenue being raised from corporate tax.

Table C. 2 shows the effective marginal tax wedge for domestic investment, broken down by asset and by type of finance. The overall effective marginal tax wedge (final column) has declined markedly during the period, with two noticeable temporary increases in 1986-87, caused by a decrease in the NPV of allowances on buildings, and in 1991, caused by a decrease in the NPV of allowances on plant and machinery. The tax wedge for buildings has fluctuated around the downward trend, 
partly due to changes in the actual level of allowances granted (which switched between 2.5 per cent p.a. and 4 per cent p.a. during the period) and partly due to the effects of changes in other aspects of the tax system. For plant and machinery, although the precise details of depreciation allowances given have changed several times, especially in the period since 1988, the level of allowances has essentially remained high. This is due to an additional investment allowance, of 20 per cent over and above the schedule of rates given by the Finance Ministry, and a special acceleration scheme in operation from 1982 to 1988. The fall in the tax wedge on inventories was caused by the decline in the statutory tax rate.

Columns 4-6 of Table C.2 show the tax wedge on an average investment, for the three different types of finance. The tax wedges on retained earnings and new equity are the same (see Table B.2) and both decline over the period. However, the tax wedge on investment financed by debt increases as a result of the fall in the statutory rate. Interest payments on debt are deductible from the corporate tax base, and hence a fall in the rate of corporate tax reduces the value of that deduction.

The domestic effective marginal tax rate, shown in the first column of Table C.3, has declined by more than half over the period, which matches the pattern shown in the tax wedges in Table C.2. Column 2 of Table C. 3 shows the effective average tax rate for a domestic investment earning a real rate of return of 40 per cent in the absence of tax. This has also declined over the period.

The third column shows the EMTR on investment into Australia from the nine other countries, weighted by the proportion of FDI coming from each country (see Table A.1). Over the period 1982-92, almost 40 per cent 
Taxing profits in a changing world

TABLE C.3

Australian effective tax rates

\begin{tabular}{|c|c|c|c|c|c|c|c|}
\hline & \multicolumn{2}{|c|}{ Domestic } & \multicolumn{2}{|c|}{ Source } & \multicolumn{3}{|c|}{ Residence } \\
\hline & EMTR & EATR & EMTR & EATR & EMTR & EATR & $A T R$ \\
\hline & & & s.d. & s.d. & s.d. & s.d. & s.d. \\
\hline & 1 & 2 & 3 & 4 & 5 & 6 & 7 \\
\hline \multirow[t]{2}{*}{1979} & 46.1 & 28.5 & 80.6 & 36.5 & 33.6 & 30.6 & \\
\hline & & & 16.2 & 1.1 & 15.1 & 1.2 & \\
\hline \multirow[t]{2}{*}{1980} & 46.1 & 28.5 & 80.6 & 36.5 & 31.6 & 30.4 & \\
\hline & & & 16.2 & 1.1 & 13.0 & 1.1 & \\
\hline \multirow[t]{2}{*}{1981} & 46.4 & 28.5 & 80.0 & 36.5 & 29.0 & 30.0 & \\
\hline & & & 3.3 & 0.6 & 16.4 & 1.4 & \\
\hline \multirow[t]{2}{*}{1982} & 32.6 & 26.7 & 64.8 & 34.7 & 28.9 & 30.0 & \\
\hline & & & 3.3 & 0.6 & 16.4 & 1.3 & \\
\hline \multirow[t]{2}{*}{1983} & 32.6 & 26.7 & 64.6 & 34.7 & 28.3 & 29.4 & \\
\hline & & & 3.5 & 0.6 & 16.9 & 2.5 & \\
\hline \multirow[t]{2}{*}{1984} & 29.0 & 26.1 & 59.7 & 34.1 & 32.1 & 28.4 & \\
\hline & & & 3.1 & 0.4 & 12.9 & 3.1 & \\
\hline \multirow[t]{2}{*}{1985} & 29.0 & 26.1 & 59.0 & 34.1 & 35.0 & 27.5 & 33.5 \\
\hline & & & 4.0 & 0.5 & 9.7 & 4.1 & 19.5 \\
\hline \multirow[t]{2}{*}{1986} & 37.1 & 27.8 & 65.7 & 35.2 & 38.3 & 26.5 & 34.9 \\
\hline & & & 6.0 & 0.5 & 7.4 & 5.0 & 15.5 \\
\hline \multirow[t]{2}{*}{1987} & 40.8 & 28.3 & 69.0 & 35.8 & 39.0 & 24.6 & 37.3 \\
\hline & & & 5.9 & 0.5 & 7.7 & 3.3 & 15.8 \\
\hline \multirow[t]{2}{*}{1988} & 26.9 & 22.5 & 59.9 & 31.0 & 37.2 & 25.5 & 34.5 \\
\hline & & & 15.3 & 2.0 & 7.4 & 3.0 & 15.2 \\
\hline \multirow[t]{2}{*}{1989} & 31.3 & 23.0 & 63.0 & 31.3 & 37.2 & 25.5 & 37.0 \\
\hline & & & 13.1 & 1.7 & 7.2 & 3.0 & 8.4 \\
\hline \multirow[t]{2}{*}{1990} & 31.3 & 23.0 & 58.9 & 30.8 & 36.7 & 25.1 & 36.2 \\
\hline & & & 8.2 & 1.0 & 7.8 & 3.2 & 11.9 \\
\hline \multirow[t]{2}{*}{1991} & 35.7 & 23.6 & 65.2 & 31.6 & 36.4 & 24.8 & 27.6 \\
\hline & & & 10.3 & 1.4 & 9.6 & 3.6 & 16.6 \\
\hline \multirow[t]{2}{*}{1992} & 33.2 & 23.2 & 62.5 & 31.2 & 36.4 & 24.9 & 30.8 \\
\hline & & & 10.3 & 1.4 & 9.5 & 3.7 & 15.6 \\
\hline \multirow[t]{2}{*}{1993} & 20.9 & 19.0 & 51.6 & 27.7 & 33.3 & 24.8 & 31.6 \\
\hline & & & 15.2 & 2.5 & 12.2 & 4.0 & 15.0 \\
\hline \multirow[t]{2}{*}{1994} & 20.9 & 19.0 & 50.7 & 27.5 & 35.6 & 25.1 & 31.0 \\
\hline & & & 14.8 & 2.3 & 9.5 & 3.6 & 15.0 \\
\hline
\end{tabular}

Notes: All rates are averaged across finance and assets. Weights used are: $28 \%$ buildings, $50 \%$ plant and machinery, $22 \%$ inventories; $55 \%$ retained earnings, $10 \%$ new equity, $35 \%$ debt. Inflation and the real interest rate are held constant at $3.5 \%$ and $10 \%$ respectively. Columns 3 and 4 are weighted across countries by the proportion of inward FDI coming from each country (see Table A.1). Columns 5 and 6 are weighted across countries by the proportion of outward FDI going to each country (see Table A.2). The EATR in columns 2, 4 and 6 is for an investment earning a $40 \%$ real rate of return in the absence of tax. ATR is the average tax rate calculated using firm-level accounting data from Global Vantage. The standard deviations are shown in italics. They measure: in columns 3 and 4 , the variation across the nine source countries; in columns 5 and 6 , the variation across the nine residence countries; and in column 7, the variation across firms resident in Australia. See Appendix A for definition and interpretation of variables. 
of Australia's FDI performed by countries in this study came from Japan, with both the UK and the US accounting for over one-quarter. All three countries operate credit systems on foreign source income. Australia also levies withholding taxes on interest of 10 per cent for these countries, and withholding taxes on dividends of 15 per cent for all of the countries covered here ${ }^{38}$ The mean and standard deviation fell after 1981, due to a reduction in the EMTR from Japan, the UK and the US, but they rose again in the late 1980s and early 1990s. The rise in the EMTR in the later period was due to the fact that the EMTR from the US and the UK declined, but that from Japan did not, leading to a rise in the standard deviation.

Column 4 of Table C. 3 shows the effective average tax rate on inward investment, again weighted by FDI flows. The standard deviation on the EATR has become larger over the period. While the EMTR suggested some degree of increase in capital import neutrality, this is not so when evaluated using the EATR.

The fifth and sixth columns show the effective tax rates for Australian multinationals investing abroad. Almost 50 per cent of Australian outward FDI during the period 1982-92 was to the UK, with another 40 per cent going to the US. The UK and the US both levy a 10 per cent withholding tax on interest income repatriated to Australia. The UK exempts dividend income (in a reciprocal arrangement), while the US imposes a 15 per cent withholding tax. Australia exempts foreign source dividend income from taxation, for countries operating 'similar tax systems' to their own, while on interest income it operates a credit system. Again, there is a decline in the standard deviation for the EMTR but a

\footnotetext{
${ }^{38}$ The exception is Spain, which faced a withholding tax of $30 \%$ until 1993 , when it was reduced to $15 \%$.
} 


\section{Taxing profits in a changing world}

rise for the EATR, indicating differential changes in the degree of capital export neutrality for projects of differing degrees of profitability.

The final column of Table C. 3 shows the average tax rate calculated using data from company accounts, where the tax rate for each firm is defined as the ratio of

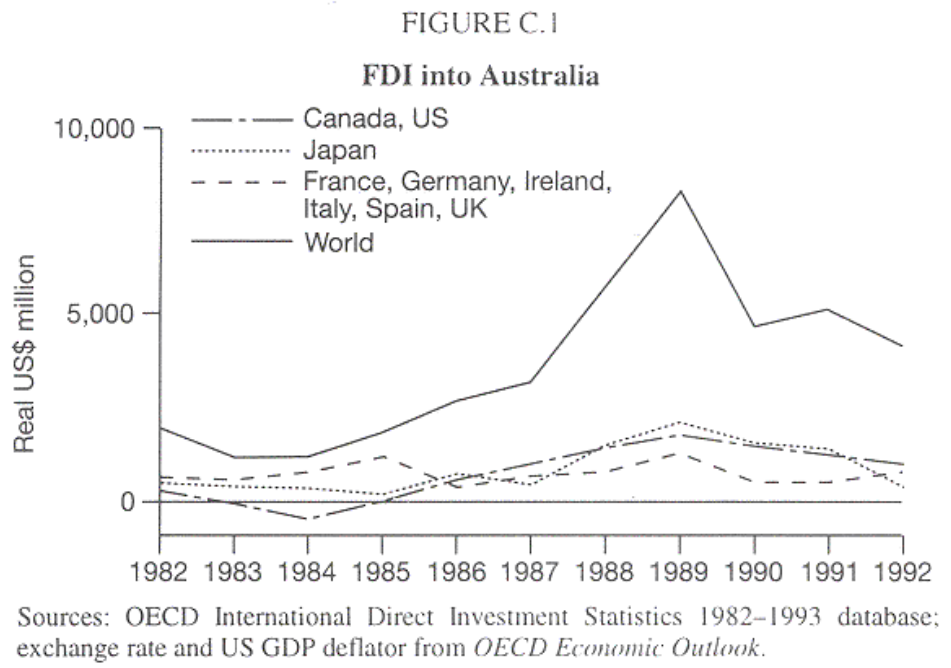

provision for tax to net pre-tax income and the median of those tax rates is presented here. From 1985 to 1990, the ATR ranged between about 33 and 37 per cent, while after 1990 it fell, hovering around 30 per cent after 1991. Comparing the ATR with the EATR for an Australian company investing abroad, the former increases in the late 1980s while the latter declines, but both hold relatively stable in the early 1990s (apart from a drop in the ATR below 30 per cent in 1991). The standard deviation on the ATR stays quite stable after 1990.

Figures C.1 and C.2 show the total amounts of foreign direct investment, both into and out of Australia, measured in millions of 1985 US dollars. For ease of presentation, the sources and destinations of the FDI 
have been broken down by geographic region of the countries covered in the study: Europe, North America and a separate group for Japan. A total for the world is also given (this includes all countries, not just those covered in this study). The absolute level of FDI into Australia from the rest of the world peaked in 1989, and much of it came from countries other than the G7; FDI from Australia peaked in 1988, and much of it went to European countries.

FIGURE C. 2

FDI from Australia

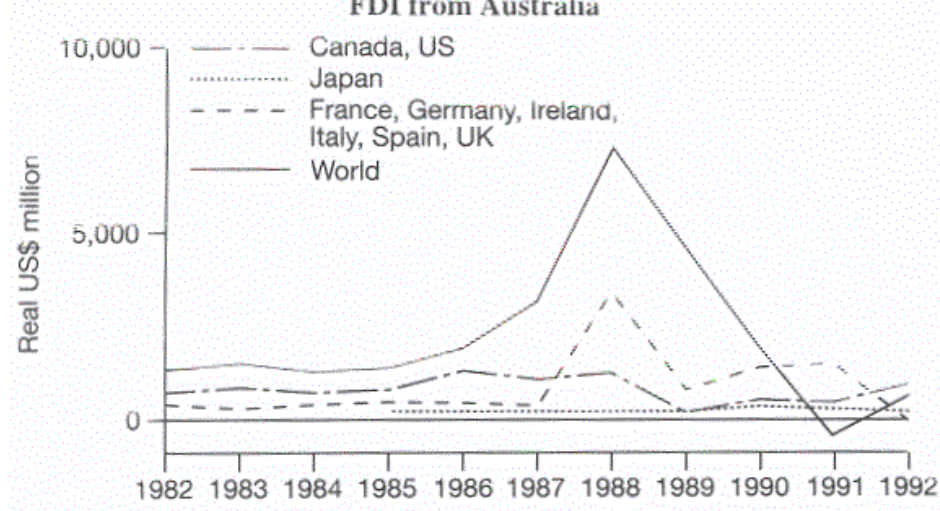

Sources OECD International Direct Investment Statistics 1982-1993 database; exchange rate and US GDP deflator from OECD Economic Outlook. 


\section{APPENDIX D \\ Canada}

The headline tax rate on corporate income in Canada fell twice over this period, in 1987 and 1988. The fluctuation in the statutory rate is due to changes in the level of a surtax levied at the national level on corporate and personal income. At the same time, however, depreciation allowances have become less generous. This has resulted in a slight increase in the overall tax wedge, as shown in the final column of Table D.2.

TABLE D.1

Canadian tax rates and NPV of allowances

\begin{tabular}{rrrrrrr}
\hline & $\begin{array}{r}\text { Headline } \\
\text { rate }\end{array}$ & $\begin{array}{r}\text { Statutory } \\
\text { rate }^{a}\end{array}$ & $\begin{array}{r}\text { NPV of } \\
\text { allowances } \\
\text { (buildings) }\end{array}$ & $\begin{array}{r}\text { NPV of } \\
\text { allowances } \\
\text { (plant and } \\
\text { machinery) }\end{array}$ & $\begin{array}{r}\text { CT } \\
\text { as a of } \\
\text { GDP }\end{array}$ & $\begin{array}{r}\text { CT as a } \\
\% \text { of } \\
\text { total } \\
\text { tax }\end{array}$ \\
\hline 1979 & 46.0 & $43.0(43.0)$ & 0.35 & 0.94 & 3.6 & 11.5 \\
1980 & 46.0 & $44.8(44.8)$ & 0.35 & 0.94 & 3.7 & 11.6 \\
1981 & 46.0 & $44.8(44.8)$ & 0.33 & 0.94 & 3.3 & 9.7 \\
1982 & 46.0 & $44.8(44.8)$ & 0.33 & 0.94 & 2.5 & 7.5 \\
1983 & 46.0 & $44.2(44.2)$ & 0.33 & 0.89 & 2.5 & 7.5 \\
1984 & 46.0 & $43.3(43.3)$ & 0.33 & 0.89 & 2.9 & 8.7 \\
1985 & 46.0 & $45.1(45.1)$ & 0.33 & 0.89 & 2.7 & 8.2 \\
1986 & 46.0 & $45.1(45.1)$ & 0.33 & 0.89 & 2.8 & 8.2 \\
1987 & 45.0 & $42.4(42.4)$ & 0.33 & 0.89 & 2.9 & 8.2 \\
1988 & 38.0 & $39.4(39.4)$ & 0.29 & 0.78 & 2.9 & 8.5 \\
1989 & 38.0 & $38.4(38.4)$ & 0.24 & 0.77 & 3.0 & 8.5 \\
1990 & 38.0 & $37.4(37.4)$ & 0.24 & 0.73 & 2.6 & 7.0 \\
1991 & 38.0 & $36.4(36.4)$ & 0.24 & 0.69 & 2.1 & 5.7 \\
1992 & 38.0 & $37.7(37.7)$ & 0.24 & 0.73 & 1.8 & 5.0 \\
1993 & 38.0 & $35.3(35.3)$ & 0.24 & 0.73 & 2.1 & 5.8 \\
1994 & 38.0 & $34.3(34.3)$ & 0.24 & 0.73 & 2.4 & 6.6 \\
\hline
\end{tabular}

The statutory rate shows, first, the rate on retained earnings and then, in parentheses, the rate on distributed profits.

Note: The statutory rate includes the headline rate, less the provincial abatement $(10 \%)$, plus a federal surtax (in years that it applies), less a manufacturing and processing deduction, plus a provincial tax rate of $13 \%$ in $1979-87,12.6 \%$ in 1988 $91,13.9 \%$ in 1992 and $12.5 \%$ in 1993 and 1994. 


\section{Canada}

TABLE D. 2

Canadian domestic effective marginal tax wedge

\begin{tabular}{l|rrr|rrr|r}
\hline & Buildings & $\begin{array}{r}\text { Plant and } \\
\text { machinery }\end{array}$ & Inventory & $\begin{array}{r}\text { Retained } \\
\text { earnings }\end{array}$ & $\begin{array}{r}\text { New } \\
\text { equity }\end{array}$ & Debt & Average \\
& 1 & 2 & 3 & 4 & 5 & 6 & 7 \\
\hline 1979 & 3.4 & -1.2 & 6.6 & 4.6 & 4.6 & -3.4 & 1.8 \\
1980 & 3.7 & -1.3 & 7.1 & 4.9 & 4.9 & -3.5 & 2.0 \\
1981 & 3.9 & -1.3 & 7.1 & 5.0 & 5.0 & -3.5 & 2.0 \\
1982 & 3.9 & -1.3 & 7.1 & 5.0 & 5.0 & -3.5 & 2.0 \\
1983 & 3.8 & -0.6 & 6.9 & 5.3 & 5.3 & -3.3 & 2.3 \\
1984 & 3.6 & -0.6 & 6.6 & 5.1 & 5.1 & -3.2 & 2.2 \\
1985 & 3.9 & -0.6 & 7.1 & 5.5 & 5.5 & -3.3 & 2.4 \\
1986 & 3.9 & -0.6 & 7.1 & 5.5 & 5.5 & -3.3 & 2.4 \\
1987 & 3.5 & -0.6 & 6.4 & 4.9 & 4.9 & -3.1 & 2.1 \\
1988 & 3.4 & 0.8 & 5.7 & 5.2 & 5.2 & -2.4 & 2.6 \\
1989 & 3.6 & 0.9 & 5.4 & 5.3 & 5.3 & -2.2 & 2.7 \\
1990 & 3.5 & 1.3 & 5.2 & 5.3 & 5.3 & -2.0 & 2.7 \\
1991 & 3.3 & 1.7 & 5.0 & 5.3 & 5.3 & -1.7 & 2.9 \\
1992 & 3.5 & 1.3 & 5.3 & 5.3 & 5.3 & -2.0 & 2.8 \\
1993 & 3.2 & 1.1 & 4.7 & 4.8 & 4.8 & -1.8 & 2.5 \\
1994 & 3.0 & 1.1 & 4.5 & 4.6 & 4.6 & -1.8 & 2.4 \\
\hline
\end{tabular}

Notes: An inventory allowance of $3 \%$ p.a. was available prior to 1986 ; this has not been modelled. Columns 1-3 are weighted averages across types of finance; columns 4-6 are weighted averages across assets; column 7 is a weighted average across both finance and assets. Weights used are: $28 \%$ buildings, $50 \%$ plant and machinery, $22 \%$ inventories; $55 \%$ retained earnings, $10 \%$ new equity, $35 \%$ debt. Inflation and the real interest rate are held constant at 3.5\% and $10 \%$ respectively. See Appendix A for definition and interpretation of variables.

Corporation tax receipts, however, have declined both as a proportion of GDP and even more so as a proportion of total tax receipts.

Table D.2 shows the effective marginal tax wedge for domestic investment, broken down by asset and by type of finance. While the overall effective marginal tax wedge (final column) has increased slightly, the wedge on buildings has decreased (first column). This is because the reduction in depreciation allowances on buildings was not large enough to offset the reduction in the statutory rate. The wedge on plant and machinery has increased substantially. Prior to 1988, the tax system gave a subsidy to investment in plant and machinery. This was because plant and machinery used for 


\section{Taxing profits in a changing world}

Canadian manufacturing operations had a 'special twoyear write-off' until 1983 and a 'special three-year write-off' from 1983 until 1987. A general Investment Tax Credit was also available for manufacturing capital expenditure (both plant and machinery and buildings) at the rate of 7 per cent up until $1989 .{ }^{39}$ In 1988 , the basic federal statutory tax rate was lowered by 7 percentage points, at the same time as depreciation allowances were made substantially less generous. The net result of these reforms was to increase the overall tax wedge by around one-half of a percentage point. The wedge on inventories has risen due to the reduction in the statutory tax rate.

Column 4 of Table D.2 shows the tax wedge on an investment financed by retained earnings averaged across assets. It is the same as the wedge for an investment financed by new equity. Canada operates a partial imputation system, i.e. it gives a tax credit on distributed profits to mitigate double taxation but the credit is not refundable. As we assume that the marginal investor is a tax-exempt shareholder, they do not benefit from this credit. For a taxpaying shareholder, the tax wedge on an investment financed by retained earnings would be higher than that on one financed by new equity. Investment financed by debt is treated more favourably than other forms of finance because interest payments are deductible, as in all countries. Due to the fall in the statutory rate, it is now treated less favourably than it was in the early 1980s.

The domestic effective marginal tax rate, shown in the first column of Table D.3, has increased slightly over the period, mirroring the increase in the wedge

\footnotetext{
${ }^{39}$ Higher rates were given in certain regions of the country; they are not modelled.
} 


\section{Canada}

shown in

TABLE D.3

\section{Canadian effective tax rates}

\begin{tabular}{|c|c|c|c|c|c|c|c|}
\hline & \multicolumn{2}{|c|}{ Domestic } & \multicolumn{2}{|c|}{ Source } & \multicolumn{3}{|c|}{ Residence } \\
\hline & EMTR & EATR & EMTR & EATR & EMTR & EATR & $A T R$ \\
\hline & & & s.d. & s.d. & s.d. & s.d. & s.d. \\
\hline & 1 & 2 & 3 & 4 & 5 & 6 & 7 \\
\hline \multirow[t]{2}{*}{1979} & 17.8 & 23.0 & 42.9 & 30.2 & 44.3 & 29.5 & \\
\hline & & & 2.6 & 0.2 & 15.5 & 1.3 & \\
\hline \multirow[t]{2}{*}{1980} & 19.5 & 24.0 & 44.1 & 31.1 & 39.9 & 29.0 & \\
\hline & & & 1.4 & 0.1 & 13.2 & 1.1 & \\
\hline \multirow[t]{2}{*}{1981} & 20.0 & 24.0 & 44.6 & 31.2 & 39.3 & 28.9 & \\
\hline & & & 1.4 & 0.1 & 16.1 & 1.4 & \\
\hline \multirow[t]{2}{*}{1982} & 20.0 & 24.0 & 44.6 & 31.2 & 39.3 & 28.9 & \\
\hline & & & 1.4 & 0.1 & 16.1 & 1.4 & \\
\hline \multirow[t]{2}{*}{1983} & 22.9 & 24.1 & 48.0 & 31.3 & 39.2 & 28.5 & \\
\hline & & & 1.2 & 0.1 & 16.7 & 2.0 & \\
\hline \multirow[t]{2}{*}{1984} & 21.9 & 23.6 & 44.6 & 30.3 & 40.5 & 28.1 & \\
\hline & & & 3.9 & 0.7 & 13.3 & 3.1 & \\
\hline \multirow[t]{2}{*}{1985} & 23.9 & 24.6 & 45.4 & 31.2 & 37.0 & 26.3 & 42.1 \\
\hline & & & 3.2 & 0.6 & 8.4 & 3.6 & 0.1 \\
\hline \multirow[t]{2}{*}{1986} & 23.9 & 24.6 & 45.3 & 31.0 & 38.4 & 26.0 & 45.7 \\
\hline & & & 9.5 & 1.4 & 6.5 & 4.7 & 3.0 \\
\hline \multirow[t]{2}{*}{1987} & 21.0 & 23.1 & 41.9 & 29.9 & 40.1 & 22.0 & 37.1 \\
\hline & & & 12.8 & 1.8 & 6.8 & 2.4 & 14.1 \\
\hline \multirow[t]{2}{*}{1988} & 25.8 & 22.5 & 48.9 & 29.4 & 38.5 & 24.0 & 29.9 \\
\hline & & & 16.7 & 2.5 & 5.6 & 2.1 & 12.4 \\
\hline \multirow[t]{2}{*}{1989} & 26.7 & 22.2 & 49.2 & 29.0 & 38.5 & 24.0 & 38.5 \\
\hline & & & 15.2 & 2.4 & 5.3 & 2.0 & 10.7 \\
\hline \multirow[t]{2}{*}{1990} & 27.4 & 21.8 & 48.1 & 28.4 & 38.3 & 23.9 & 37.0 \\
\hline & & & 11.4 & 2.0 & 6.2 & 2.5 & 14.1 \\
\hline \multirow[t]{2}{*}{1991} & 28.6 & 21.6 & 50.4 & 28.3 & 38.4 & 23.8 & 30.6 \\
\hline & & & 14.1 & 2.5 & 8.4 & 3.1 & 10.1 \\
\hline \multirow[t]{2}{*}{1992} & 27.8 & 22.0 & 49.2 & 28.7 & 38.7 & 23.6 & 30.6 \\
\hline & & & 13.1 & 2.2 & 8.5 & 3.2 & 9.5 \\
\hline \multirow[t]{2}{*}{1993} & 24.9 & 20.6 & 46.7 & 27.4 & 39.8 & 24.6 & 31.2 \\
\hline & & & 14.5 & 2.6 & 9.9 & 3.2 & 22.8 \\
\hline \multirow[t]{2}{*}{1994} & 23.8 & 20.0 & 45.1 & 26.7 & 40.7 & 24.7 & 30.6 \\
\hline & & & 13.9 & 2.6 & 7.7 & 2.8 & 15.0 \\
\hline
\end{tabular}

Notes: All rates are averaged across finance and assets. Weights used are: $28 \%$ buildings, $50 \%$ plant and machinery, $22 \%$ inventories; $55 \%$ retained earnings, $10 \%$ new equity, $35 \%$ debt. Inflation and the real interest rate are held constant at $3.5 \%$ and $10 \%$ respectively. Columns 3 and 4 are weighted across countries by the proportion of inward FDI coming from each country (see Table A.1). Columns 5 and 6 are weighted across countries by the proportion of outward FDI going to each country (see Table A.2). The EATR in columns 2, 4 and 6 is for an investment earning a $40 \%$ real rate of return in the absence of tax. ATR is the average tax rate calculated using firm-level accounting data from Global Vantage. The standard deviations are shown in italics. They measure: in columns 3 and 4 , the variation 
across the nine source countries; in columns 5 and 6 , the variation across the nine residence countries; and in column 7 , the variation across firms resident in Canada. See Appendix A for definition and interpretation of variables.

the final column of Table D.2. Column 2 of Table D.3 shows the effective average tax rate for a domestic investment earning a real rate of return of 40 per cent in the absence of tax. The EATR has declined slightly over the period while the EMTR has increased. This is because the impact of tax reform in Canada over this period has been to lower the statutory rate and broaden the base (make depreciation allowances worth less). At higher levels of profitability, the impact of depreciation allowances is reduced, and the EATR tends toward the statutory tax rate.

The third column shows the EMTR on investment into Canada from the nine other countries, weighted by the proportion of FDI coming from each country (see Table A.1). This fluctuates between 40 and 50 per cent, reaching its highest levels around 1991 but falling to 45 per cent by 1994. Over the period 1982-92, more than half of Canada's FDI performed by countries in this study came from the US and around a quarter came from each of Japan and the UK. All three of these countries operate various types of credit systems for foreign source income. This means that, where the statutory tax rate in the residence country is higher than in Canada, the EMTR on inward FDI will also be higher. In addition, Canada levies a withholding tax on both dividends and interest. For all three of the main capital exporters, the withholding tax rate on both interest and dividends has fallem from 15 per cent in 1979 to 10 per cent in 1994 . $^{40}$ The increase in the standard deviation in the late 1980s is due to an increase in the EMTR on investment from Japan and a decrease in the EMTR from both the UK and the US.

${ }^{40}$ For the US, it has since fallen to $6 \%$. 
The fourth column of Table D.3 shows the effective average tax rate on inward investment, again weighted by FDI flows. While the EATR rises slightly until the mid-1980s, it falls somewhat by 1994. The standard deviation for the EATR shows a similar pattern to that for the EMTR, indicating that both measures show a decrease in the degree of capital import neutrality for investment into Canada by the end of this period.

Columns 5 and 6 show the effective tax rates for Canadian multinationals investing abroad. Over 80 per cent of Canadian outward FDI during the period 198292 went to the US, with around 17 per cent going to the UK. The US levies withholding taxes of 15 per cent on interest income and 10 per cent on dividend income (15 per cent prior to 1985) from Canada. Canada exempts foreign source dividend income from taxation; however, on interest income it operates a credit system and levies a higher statutory tax rate by disallowing the provincial abatement, giving a statutory tax rate on foreign source income equal to the headline rate shown in Table D.1. The standard deviation of the EMTR has declined, while that on the EATR has increased. Thus the EMTR shows an increase in the degree of capital export neutrality, while the measure for more profitable projects (the EATR) shows a decrease.

The final column of Table D.3 shows the average tax rate calculated using data from company accounts, where the tax rate for each firm is defined as the ratio of provision for tax to net pre-tax income and the median of those tax rates is presented here. In the first two years for which data are available, the ATR was over 40 per cent, but it fell over the period, stabilising at about 30 per cent. Apart from the first two years, when the sample size was very small (see Table A.6), the standard deviation on the ATR is relatively constant (except in 1993). 
Taxing profits in a changing world

Figures D.1 and D.2 show the total amounts of foreign direct investment, both into and out of Canada, 


\section{Canada}

FIGURE D.1

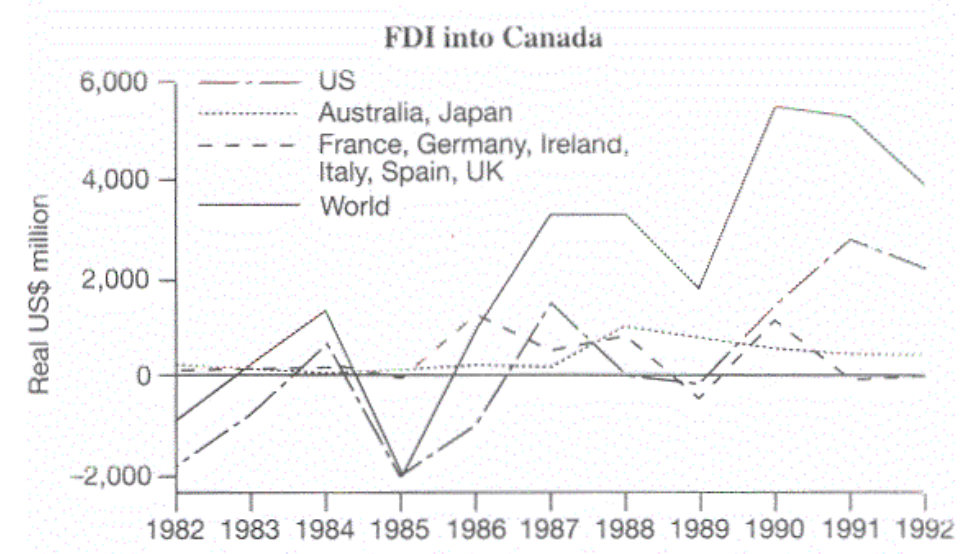

Sources: OECD International Direct Investunent Statistics 1982-1993 database. exchange rate and US GDP deflator from OECD Economic Outlook.

FIGURE D.2

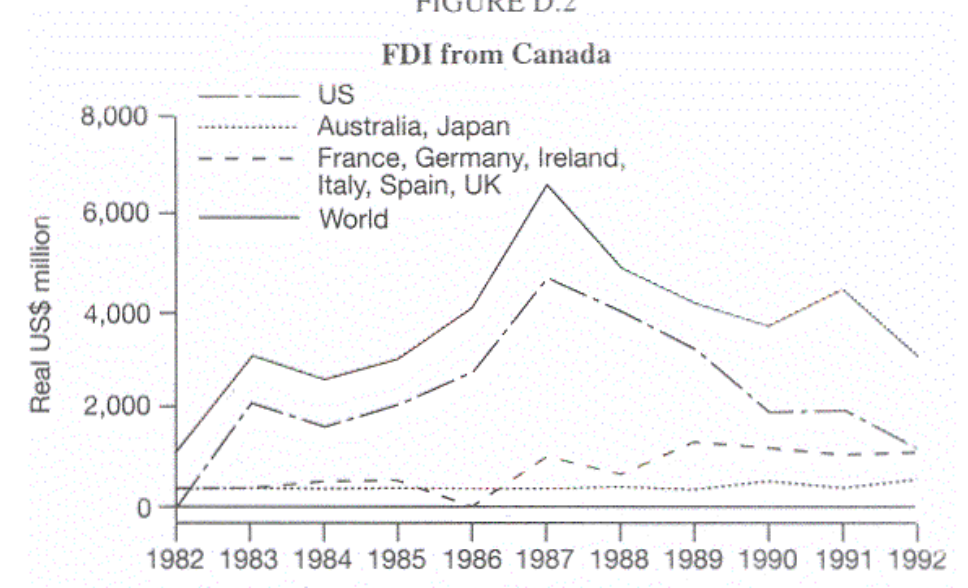

Suurces: OECD International Direct Investment Statistics 1982-1993 database. exchange rate and US GDP deflator from OECD Economic Outlook. 
Taxing profits in a changing world

measured in millions of 1985 US dollars. For ease of presentation, the sources and destinations of the FDI have been broken down by geographic region of the countries covered in the study: Europe, the US and a separate group for Australia and Japan. A total for the world is also given (this includes all countries, not just those covered in this study). During the 1980s, Canada suffered a large negative inflow of FDI from the US (i.e. repatriation of FDI). In 1986, this was offset by FDI from other sources, mainly the UK. By the early 1990s, the flow from the US was positive. The dominant feature of FDI from Canada is that the majority of that investment goes to the US. 


\section{APPENDIX E}

France

The French statutory rate on retained earnings has fallen steadily over the period. The value of depreciation allowances has remained basically the same, although between 1981 and 1985 an additional initial allowance was given on investment in plant and machinery. As a result, the overall tax wedge has fallen from 2.5 per cent in 1979 to 0.8 per cent in 1994, as shown in the final column of Table E.2. Corporation tax receipts have hovered around 2 per cent of GDP, and around 3 to 5 per cent of total tax receipts.

TABLE E.1

French tax rates and NPV of allowances

\begin{tabular}{|c|c|c|c|c|c|c|}
\hline & $\begin{array}{r}\text { Headline } \\
\text { rate }\end{array}$ & $\begin{array}{r}\text { Statutory } \\
\text { rate }^{a}\end{array}$ & $\begin{array}{r}N P V \text { of } \\
\text { allowances } \\
\text { (buildings) }\end{array}$ & $\begin{array}{r}N P V \text { of } \\
\text { allowances } \\
\text { (plant and } \\
\text { machinery) }\end{array}$ & $\begin{array}{c}C T \\
\text { as a } \\
\% \text { of } \\
G D P\end{array}$ & $\begin{array}{r}C T \text { as a } \\
\% \text { of } \\
\text { total } \\
\text { tax } \\
\text { receipts }\end{array}$ \\
\hline 1979 & 50.0 & $50.0(50.0)$ & 0.38 & 0.81 & 1.9 & 4.7 \\
\hline 1980 & 50.0 & $50.0(50.0)$ & 0.38 & 0.81 & 2.1 & 5.1 \\
\hline 1981 & 50.0 & $50.0(50.0)$ & 0.38 & 0.87 & 2.2 & 5.2 \\
\hline 1982 & 50.0 & $50.0(50.0)$ & 0.38 & 0.87 & 2.3 & 5.3 \\
\hline 1983 & 50.0 & $50.0(50.0)$ & 0.38 & 0.87 & 2.0 & 4.6 \\
\hline 1984 & 50.0 & $50.0(50.0)$ & 0.38 & 0.87 & 1.9 & 4.4 \\
\hline 1985 & 50.0 & $50.0(50.0)$ & 0.38 & 0.87 & 2.0 & 4.5 \\
\hline 1986 & 45.0 & $45.0(50.0)$ & 0.38 & 0.81 & 2.2 & 5.0 \\
\hline 1987 & 45.0 & $45.0(45.0)$ & 0.38 & 0.81 & 2.3 & 5.1 \\
\hline 1988 & 42.0 & $42.0(42.0)$ & 0.38 & 0.81 & 2.3 & 5.3 \\
\hline 1989 & 39.0 & $39.0(42.0)$ & 0.38 & 0.81 & 2.4 & 5.5 \\
\hline 1990 & 37.0 & $37.0(42.0)$ & 0.38 & 0.81 & 2.3 & 5.3 \\
\hline 1991 & 34.0 & $34.0(42.0)$ & 0.38 & 0.81 & 2.0 & 4.5 \\
\hline 1992 & 34.0 & $34.0(34.0)$ & 0.38 & 0.81 & 1.5 & 3.5 \\
\hline 1993 & 33.3 & $33.3(33.3)$ & 0.38 & 0.81 & 1.5 & 3.4 \\
\hline 1994 & 33.3 & $33.3(33.3)$ & 0.38 & 0.81 & 1.6 & 3.7 \\
\hline
\end{tabular}


Taxing profits in a changing world

TABLE E.2

French domestic effective marginal tax wedge

\begin{tabular}{l|rrr|rrr|r}
\hline & Buildings & $\begin{array}{r}\text { Plant and } \\
\text { machinery }\end{array}$ & Inventory & $\begin{array}{r}\text { Retained } \\
\text { earnings }\end{array}$ & $\begin{array}{r}\text { New } \\
\text { equity }\end{array}$ & Debt & Average \\
& 1 & 2 & 3 & 4 & 5 & 6 & 7 \\
\hline 1979 & 3.0 & 0.1 & 7.4 & 7.4 & -3.0 & -3.6 & 2.5 \\
1980 & 3.0 & 0.1 & 7.4 & 7.4 & -3.0 & -3.6 & 2.5 \\
1981 & 3.0 & -1.2 & 7.4 & 6.7 & -3.6 & -4.1 & 1.9 \\
1982 & 3.0 & -1.1 & 7.4 & 6.7 & -3.5 & -4.0 & 2.0 \\
1983 & 3.0 & -1.1 & 7.4 & 6.7 & -3.5 & -4.0 & 1.9 \\
1984 & 3.0 & -1.1 & 7.4 & 6.7 & -3.5 & -4.0 & 1.9 \\
1985 & 3.0 & -1.1 & 7.4 & 6.7 & -3.5 & -4.0 & 1.9 \\
1986 & 2.5 & -0.1 & 6.1 & 6.0 & -2.1 & -3.1 & 2.0 \\
1987 & 2.3 & -0.2 & 6.0 & 6.0 & -3.4 & -3.1 & 1.9 \\
1988 & 2.0 & -0.3 & 5.2 & 5.3 & -3.6 & -2.9 & 1.6 \\
1989 & 1.7 & -0.3 & 4.7 & 4.7 & -3.1 & -2.7 & 1.4 \\
1990 & 1.6 & -0.3 & 4.3 & 4.3 & -2.8 & -2.5 & 1.2 \\
1991 & 1.4 & -0.3 & 3.8 & 3.8 & -2.4 & -2.3 & 1.1 \\
1992 & 1.2 & -0.5 & 3.6 & 3.8 & -4.0 & -2.3 & 0.9 \\
1993 & 1.2 & -0.5 & 3.5 & 3.7 & -4.0 & -2.2 & 0.8 \\
1994 & 1.2 & -0.5 & 3.5 & 3.7 & -4.0 & -2.2 & 0.8 \\
\hline
\end{tabular}

Notes: Columns 1-3 are weighted averages across types of finance; columns 4-6 are weighted averages across assets; column 7 is a weighted average across both finance and assets. Weights used are: $28 \%$ buildings, $50 \%$ plant and machinery, $22 \%$ inventories; $55 \%$ retained earnings, $10 \%$ new equity, $35 \%$ debt. Inflation and the real interest rate are held constant at $3.5 \%$ and $10 \%$ respectively. See Appendix A for definition and interpretation of variables.

Table E. 2 shows the effective marginal tax wedge for domestic investment, broken down by asset and by type of finance. The tax wedge decreased overall and across all assets. Both new equity and debt remain taxprivileged forms of finance. The favourable treatment for new equity is caused by a special allowance. The fall in the statutory rate has reduced the size of the tax subsidy to debt.

As with the domestic tax wedge, the domestic effective marginal tax rate, shown in the first column of Table E.3, has substantially declined over the period. Column 2 shows the effective average tax rate for a domestic investment earning a real rate of return of 40 per cent in the absence of tax. The effective average tax rate has also declined steadily over the period. 
France

TABLE E.3

French effective tax rates

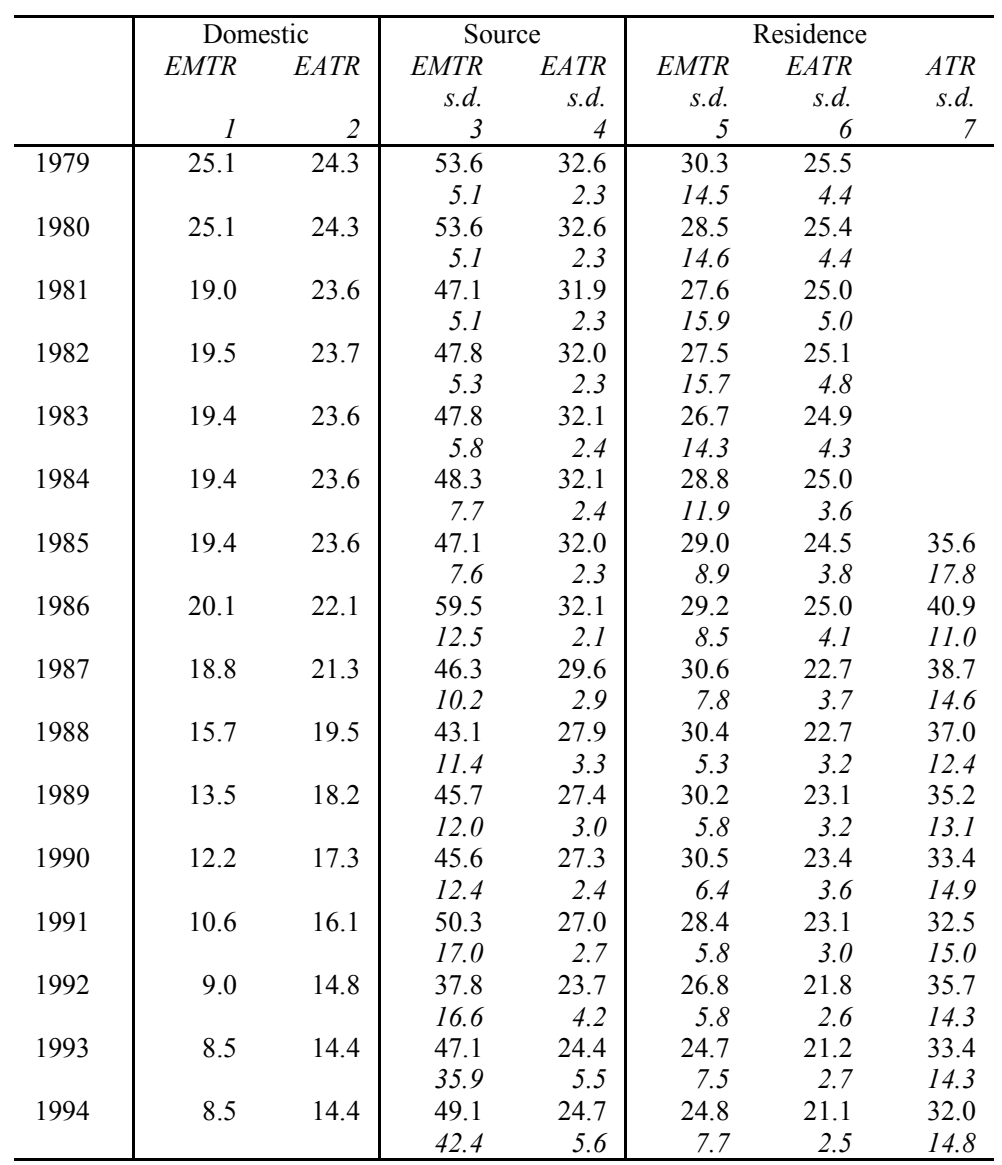

Notes: All rates are averaged across finance and assets. Weights used are: $28 \%$ buildings, $50 \%$ plant and machinery, $22 \%$ inventories; $55 \%$ retained earnings, $10 \%$ new equity, $35 \%$ debt. Inflation and the real interest rate are held constant at $3.5 \%$ and $10 \%$ respectively. Columns 3 and 4 are weighted across countries by the proportion of inward FDI coming from each country (see Table A.1). Columns 5 and 6 are weighted across countries by the proportion of outward FDI going to each country (see Table A.2). The EATR in columns 2, 4 and 6 is for an investment earning a $40 \%$ real rate of return in the absence of tax. ATR is the average tax rate calculated using firm-level accounting data from Global Vantage. The standard deviations are shown in italics. They measure: in columns 3 and 4 , the variation across the nine source countries; in columns 5 and 6 , the variation across the nine residence countries; and in column 7, the variation across firms resident in France. See Appendix A for definition and interpretation of variables. 


\section{Taxing profits in a changing world}

Columns 3 and 4 show the effective tax rates on investment into France. These are weighted averages across the nine other countries, weighted by the proportion of FDI coming from each country (see Table A.1). Over 1982-92, the pattern of FDI into France performed by countries in this study was dominated by European countries, in particular Germany, Italy and the UK. Some non-European countries were significant investors, including the US, which alone accounts for one-quarter of the FDI into France, while Japan adds almost one-tenth. France has no withholding tax on interest income after 1986, although it was set at rates of 10 or 15 per cent prior to 1986 . Withholding taxes on dividend income are usually 10 or 15 per cent, and the tax credit on dividends - the avoir fisfal - is not usually given to foreign parent companies. ${ }^{41}$ The EMTR on inward investment shown in column 3 fluctuates over time, but ends the period slightly lower, at 49 per cent rather than 54 per cent, significantly higher than the marginal tax rate on domestic investment. By contrast, the EATR is lower and falls steadily.

The fifth and sixth columns show the effective tax rates for French multinationals investing abroad. These are weighted averages across the nine other countries, weighted by the proportion of FDI going from France to each country (see Table A.2). Almost 40 per cent of French outward FDI during the period 1982-92 was to the US, another one-fifth to the UK, and Germany, Italy and Spain were the other significant recipients of French investment. France operates a credit system for interest income arising from foreign sources, but exempts 95 per cent of dividend income. Both the US and the UK

\footnotetext{
${ }^{41}$ The exception is Italy, whose treaty now allows for half of the avoir fiscal to be refunded to the Italian parent, and a rate of withholding of 5\% is applied.
} 
levied withholding taxes of 10 per cent on interest being returned to France, which were reduced to zero in 1990. The US imposes a 5 per cent withholding tax on dividends returning to France; the UK does not tax these payments.

Both the EMTR and EATR on outward investment from France have fallen somewhat over the period. It has always been cheaper for French companies to invest abroad than for foreign companies to invest in France, although this is more notable at lower levels of profitability. The EATRs on inward and outward investment are much closer together than the EMTRs.

The final column of Table E. 3 shows the average tax rate calculated using data from company accounts, where the tax rate for each firm is defined as the ratio of provision for tax to net pre-tax income and the median of those tax rates is presented here. The ATR is slightly higher in the five years from 1985 to 1989 (35 per cent or above) than it is from 1990 (largely remaining at 32 or 33 per cent).

The standard deviations on inward investment (both source EMTR and source EATR) have increased substantially over the period, indicating that there is a lower degree of capital import neutrality in France by the end of the period. However, the standard deviation on outward investment falls, whichever measure is considered. This indicates a higher degree of capital export neutrality by the end of the period.

Figures E.1 and E.2 show the total amounts of foreign direct investment, both into and out of France, measured in millions of 1985 US dollars. For ease of presentation, the sources and destinations of the FDI have been broken down by geographic region of the countries covered in the study: Europe excluding France, North America and a separate group for 
Taxing profits in a changing world

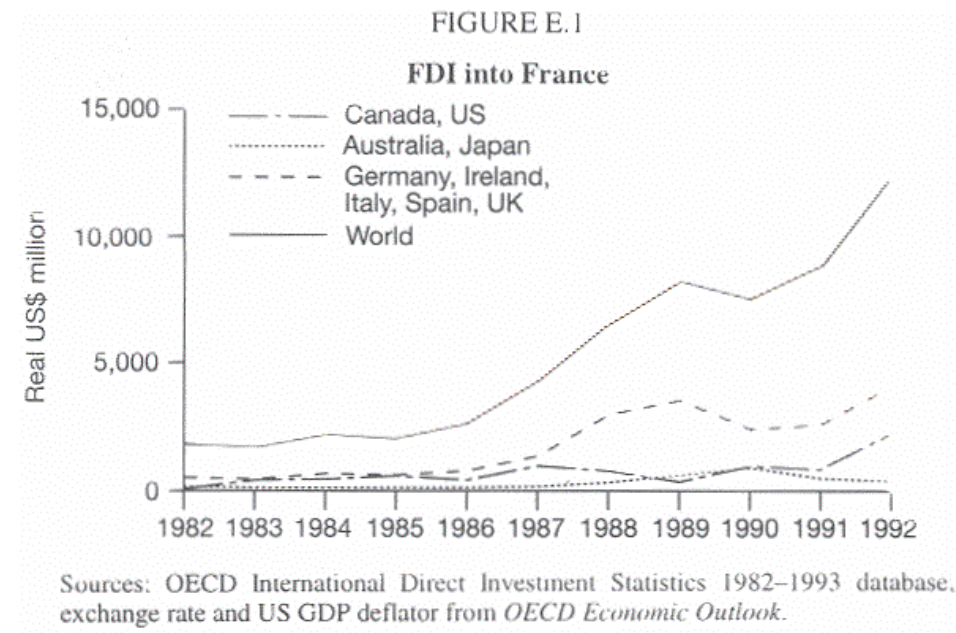

FIGURE E. 2

FDI from France

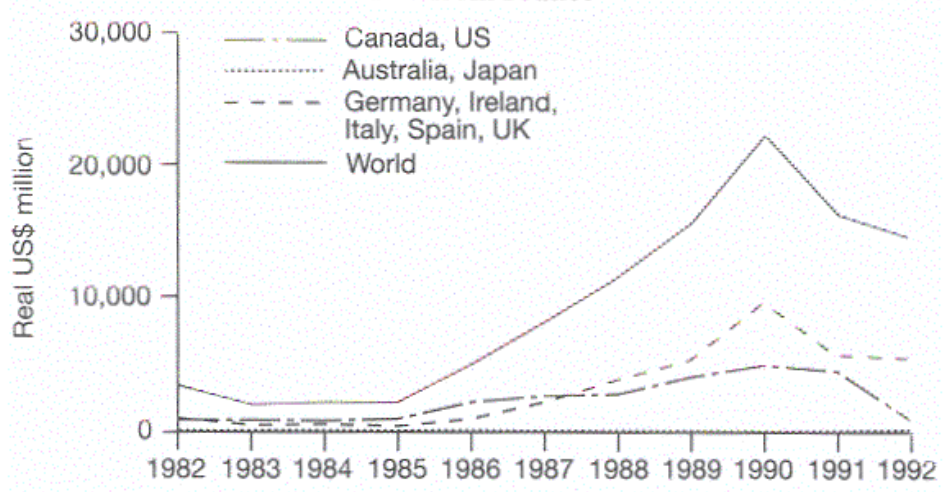

Sources OECD International Direct Investment Statistics 1982-1993 database: exchange rate and US GDP deflator from OECD Economic Outlook.

Australia and Japan. A total for the world is also given (this includes all countries, not just those covered in this study). Although the gradual increase in FDI into France is mirrored by the contribution provided by the 
European countries in our sample, these account for less than half the total FDI from the whole world. The pattern is similar for FDI out of France, but this peaks in 1990 rather than continuing to increase in absolute value. 


\section{APPENDIX F \\ Germany}

Throughout most of the period, the German statutory tax rate has been the highest of the countries considered here, although a significant decrease in 1994 meant that it fell slightly below Italy and Japan. However, a surcharge reintroduced in 1995 increases the rate again. Germany operates a split-rate system with the statutory rate on distributed profits set significantly lower than that on retained earnings. There have been two reductions in the headline rate, one in 1990 and the other in 1994. Depreciation allowances on buildings

TABLE F.1

German tax rates and NPV of allowances

\begin{tabular}{rrrrrrr}
\hline & $\begin{array}{r}\text { Headline } \\
\text { rate }\end{array}$ & $\begin{array}{r}\text { Statutory } \\
\text { rate }^{a}\end{array}$ & $\begin{array}{r}\text { NPV of } \\
\text { allowances } \\
\text { (buildings) }\end{array}$ & $\begin{array}{r}\text { NPV of } \\
\text { allowances } \\
\text { (plant and } \\
\text { machinery) }\end{array}$ & $\begin{array}{r}\text { CT } \\
\text { as } a \\
\text { o of } \\
\text { GDP }\end{array}$ & $\begin{array}{r}\text { CT as } a \\
\% \text { of } \\
\text { total } \\
\text { tax }\end{array}$ \\
\hline 1979 & 56.0 & $61.8(44.4)$ & 0.26 & 0.76 & 2.3 & 6.0 \\
1980 & 56.0 & $61.8(44.4)$ & 0.26 & 0.76 & 2.1 & 5.5 \\
1981 & 56.0 & $61.8(44.4)$ & 0.26 & 0.76 & 1.9 & 5.0 \\
1982 & 56.0 & $61.8(44.4)$ & 0.26 & 0.76 & 1.9 & 5.1 \\
1983 & 56.0 & $61.8(44.4)$ & 0.32 & 0.80 & 1.9 & 5.1 \\
1984 & 56.0 & $61.8(44.4)$ & 0.32 & 0.80 & 2.0 & 5.4 \\
1985 & 56.0 & $61.8(44.4)$ & 0.49 & 0.80 & 2.3 & 6.1 \\
1986 & 56.0 & $61.8(44.4)$ & 0.49 & 0.80 & 2.2 & 6.0 \\
1987 & 56.0 & $61.8(44.4)$ & 0.49 & 0.80 & 1.9 & 5.1 \\
1988 & 56.0 & $61.8(44.4)$ & 0.49 & 0.80 & 2.0 & 5.3 \\
1989 & 56.0 & $61.8(44.4)$ & 0.49 & 0.80 & 2.1 & 5.5 \\
1990 & 50.0 & $56.6(44.4)$ & 0.49 & 0.80 & 1.8 & 4.8 \\
1991 & 50.0 & $58.2(45.6)$ & 0.49 & 0.80 & 1.6 & 4.3 \\
1992 & 50.0 & $58.2(45.6)$ & 0.49 & 0.80 & 1.6 & 4.0 \\
1993 & 50.0 & $56.6(44.4)$ & 0.49 & 0.80 & 1.4 & 3.6 \\
1994 & 45.0 & $52.2(39.2)$ & 0.49 & 0.80 & 1.1 & 2.9 \\
\hline
\end{tabular}

${ }^{a}$ The statutory rate shows, first, the rate on retained earnings and then, in parentheses, the rate on distributed profits. It includes local taxes and a 'Solidarity' Surcharge of $3.75 \%$ on individual and corporation tax for 1991 and 1992; a surcharge on corporate tax only of $7.5 \%$ was introduced in 1995 . 
Germany

TABLE F.2

German domestic effective marginal tax wedge

\begin{tabular}{l|rrr|rrr|r}
\hline & Buildings & $\begin{array}{r}\text { Plant and } \\
\text { machinery }\end{array}$ & Inventory & $\begin{array}{r}\text { Retained } \\
\text { earnings }\end{array}$ & $\begin{array}{r}\text { New } \\
\text { equity }\end{array}$ & Debt & Average \\
& 1 & 2 & 3 & 4 & 5 & 6 & 7 \\
\hline 1979 & 7.4 & 2.3 & 6.6 & 12.4 & -3.6 & -5.1 & 4.7 \\
1980 & 7.4 & 2.3 & 6.6 & 12.4 & -3.6 & -5.1 & 4.7 \\
1981 & 7.4 & 2.3 & 6.6 & 12.4 & -3.6 & -5.1 & 4.7 \\
1982 & 7.4 & 2.3 & 6.6 & 12.4 & -3.6 & -5.1 & 4.7 \\
1983 & 6.5 & 1.3 & 6.6 & 11.4 & -4.0 & -5.5 & 3.9 \\
1984 & 6.5 & 1.3 & 6.6 & 11.4 & -4.0 & -5.5 & 3.9 \\
1985 & 3.8 & 1.3 & 6.6 & 10.3 & -4.4 & -5.9 & 3.2 \\
1986 & 3.8 & 1.3 & 6.6 & 10.3 & -4.4 & -5.9 & 3.2 \\
1987 & 3.8 & 1.3 & 6.6 & 10.3 & -4.4 & -5.9 & 3.2 \\
1988 & 3.8 & 1.3 & 6.6 & 10.3 & -4.4 & -5.9 & 3.2 \\
1989 & 3.8 & 1.3 & 6.6 & 10.3 & -4.4 & -5.9 & 3.2 \\
1990 & 2.9 & 0.8 & 5.4 & 8.3 & -3.7 & -5.2 & 2.4 \\
1991 & 3.2 & 1.0 & 5.8 & 8.9 & -3.6 & -5.4 & 2.7 \\
1992 & 3.2 & 1.0 & 5.8 & 8.9 & -3.6 & -5.4 & 2.7 \\
1993 & 2.9 & 0.8 & 5.4 & 8.3 & -3.7 & -5.2 & 2.4 \\
1994 & 2.4 & 0.5 & 4.5 & 7.0 & -3.1 & -4.6 & 1.9 \\
\hline
\end{tabular}

Notes: Columns 1-3 are weighted averages across types of finance; columns 4-6 are weighted averages across assets; column 7 is a weighted average across both finance and assets. Weights used are: $28 \%$ buildings, $50 \%$ plant and machinery, $22 \%$ inventories; $55 \%$ retained earnings, $10 \%$ new equity, 35\% debt. Inflation and the real interest rate are held constant at 3.5\% and $10 \%$ respectively. See Appendix A for definition and interpretation of variables.

have become more generous over time and are second only to Spain in generosity, while on plant and machinery they have increased only slightly. This has resulted in a large decrease in the overall tax wedge, as shown in the final column of Table F.2. This decrease is reflected in a decline in corporation tax receipts both as a proportion of GDP and as a proportion of total tax revenue.

Table F. 2 shows the effective marginal tax wedge for domestic investment, broken down by asset and by type of finance. All three types of asset have seen a decline in the tax wedge, as a result both of the increase in allowances and of the fall in the corporate tax rate. Although the overall tax wedge has decreased 


\section{Taxing profits in a changing world}

dramatically, the decrease in the statutory rate led to a slight increase in the wedge on new equity and debt. The relatively favourable treatment of new equity is due to the split-rate system.

As with the wedge in the final column of Table F.2, the domestic effective marginal tax rate in column 1 of Table F. 3 has declined. Column 2 shows the effective average tax rate for a domestic investment earning a real rate of return of 40 per cent in the absence of tax. This has also fallen, although by only 1 percentage point over the entire period.

Columns 3 and 4 show the effective tax rates on investment into Germany. These are weighted averages across the nine other countries, weighted by the proportion of FDI coming from each country (see Table A.1). Over the period 1982-92, 30 per cent of foreign investment into Germany performed by countries in this study came from France, and a fifth from each of Japan and the US. The UK and Italy provided 13 per cent and 9 per cent respectively. All of the three largest sources of FDI operate credit systems for the treatment of income from foreign sources. Germany exempts interest income returned to these countries, but levies withholding taxes on dividends at various rates, falling from 25 per cent in 1979 to between 5 and 15 per cent by 1994 .

Both the EMTR and EATR on inward investment fall over the period, with the EMTR falling from a high of 60 per cent in 1979 to below 30 per cent by 1994. The resulting EMTR on inward investment is still substantially higher than the domestic EMTR.

The fifth and sixth columns of Table F.3 show the effective tax rates for German multinationals investing abroad. Over 40 per cent of German outward FDI during the period 1982-92 was to the US, 15 per cent to the UK and 12 per cent to France, while no other 
Germany

country in

TABLE F.3

German effective tax rates

\begin{tabular}{|c|c|c|c|c|c|c|c|}
\hline & \multicolumn{2}{|c|}{ Domestic } & \multicolumn{2}{|c|}{ Source } & \multicolumn{3}{|c|}{ Residence } \\
\hline & $\begin{array}{c}E M T R \\
1\end{array}$ & EATR & $\begin{array}{r}E M T R \\
\text { s.d. } \\
3\end{array}$ & $\begin{array}{r}E A T R \\
\text { s.d. } \\
4\end{array}$ & $\begin{array}{r}E M T R \\
s . d . \\
5\end{array}$ & $\begin{array}{r}E A T R \\
\text { s.d. } \\
6\end{array}$ & $\begin{array}{r}\text { ATR } \\
\text { s.d. } \\
7\end{array}$ \\
\hline \multirow[t]{2}{*}{1979} & 46.9 & 20.5 & 60.6 & 31.6 & 54.8 & 27.1 & \\
\hline & & & 7.0 & 2.3 & 24.7 & 3.8 & \\
\hline \multirow[t]{2}{*}{1980} & 46.9 & 20.5 & 60.6 & 31.6 & 52.3 & 26.9 & \\
\hline & & & 7.0 & 2.3 & 22.7 & 3.7 & \\
\hline \multirow[t]{2}{*}{1981} & 46.9 & 20.5 & 60.6 & 31.6 & 51.8 & 24.5 & \\
\hline & & & 7.0 & 2.3 & 23.7 & 10.1 & \\
\hline \multirow[t]{2}{*}{1982} & 46.9 & 20.5 & 60.6 & 31.7 & 52.2 & 24.7 & \\
\hline & & & 6.9 & 2.3 & 23.9 & 10.1 & \\
\hline \multirow[t]{2}{*}{1983} & 39.4 & 19.8 & 50.0 & 30.1 & 52.4 & 24.5 & \\
\hline & & & 7.0 & 2.5 & 24.3 & 10.1 & \\
\hline \multirow[t]{2}{*}{1984} & 39.4 & 19.8 & 49.5 & 30.0 & 54.2 & 24.5 & \\
\hline & & & 7.4 & 2.5 & 22.0 & 10.2 & \\
\hline \multirow[t]{2}{*}{1985} & 31.9 & 18.9 & 41.4 & 29.1 & 55.3 & 24.1 & 38.8 \\
\hline & & & 7.4 & 2.5 & 20.2 & 10.3 & 17.0 \\
\hline \multirow[t]{2}{*}{1986} & 31.9 & 18.9 & 43.2 & 29.8 & 59.5 & 24.0 & 43.0 \\
\hline & & & 7.2 & 2.3 & 17.9 & 10.6 & 16.0 \\
\hline \multirow[t]{2}{*}{1987} & 31.9 & 18.9 & 41.9 & 29.6 & 59.7 & 21.5 & 40.5 \\
\hline & & & 6.4 & 2.4 & 20.7 & 9.4 & 11.6 \\
\hline \multirow[t]{2}{*}{1988} & 31.9 & 18.9 & 39.4 & 29.0 & 60.8 & 21.3 & 33.4 \\
\hline & & & 4.3 & 1.3 & 22.1 & 9.2 & 13.6 \\
\hline \multirow[t]{2}{*}{1989} & 31.9 & 18.9 & 38.8 & 29.1 & 62.2 & 21.3 & 33.1 \\
\hline & & & 3.3 & 1.3 & 21.1 & 9.1 & 15.4 \\
\hline \multirow[t]{2}{*}{1990} & 24.1 & 19.9 & 39.0 & 29.5 & 53.1 & 22.8 & 35.4 \\
\hline & & & 4.4 & 0.8 & 17.6 & 8.3 & 16.3 \\
\hline \multirow[t]{2}{*}{1991} & 26.6 & 20.1 & 34.3 & 28.1 & 56.2 & 22.5 & 32.1 \\
\hline & & & 9.3 & 2.5 & 17.4 & 8.6 & 16.4 \\
\hline \multirow[t]{2}{*}{1992} & 26.6 & 20.1 & 33.2 & 27.2 & 44.0 & 19.3 & 32.3 \\
\hline & & & 10.6 & 3.5 & 16.9 & 8.0 & 18.0 \\
\hline \multirow[t]{2}{*}{1993} & 24.1 & 19.9 & 31.6 & 26.7 & 38.3 & 18.7 & 28.2 \\
\hline & & & 10.9 & 3.3 & 13.7 & 7.0 & 17.1 \\
\hline \multirow[t]{2}{*}{1994} & 19.2 & 19.5 & 27.5 & 24.9 & 35.5 & 20.0 & 27.1 \\
\hline & & & 13.8 & 4.1 & 11.6 & 6.5 & 15.1 \\
\hline
\end{tabular}

Notes: All rates are averaged across finance and assets. Weights used are: $28 \%$ buildings, $50 \%$ plant and machinery, $22 \%$ inventories; $55 \%$ retained earnings, $10 \%$ new equity, $35 \%$ debt. Inflation and the real interest rate are held constant at $3.5 \%$ and $10 \%$ respectively. Columns 3 and 4 are weighted across countries by the proportion of inward FDI coming from each country (see Table A.1). Columns 5 and 6 are weighted across countries by the proportion of outward FDI going to each country (see Table A.2). The EATR in columns 2, 4 and 6 is for an investment earning a $40 \%$ real rate of return in the absence of tax. ATR is the average tax rate calculated using firm-level accounting data from Global Vantage. The standard deviations are shown in italics. They measure: in columns 3 and 4 , the variation 
across the nine source countries; in columns 5 and 6 , the variation across the nine residence countries; and in column 7 , the variation across firms resident in Germany. See Appendix A for definition and interpretation of variables.

the study received more than 10 per cent of German FDI. Germany gives a credit for taxes paid on interest income earned abroad and exempts dividend income. Although the US levies a withholding tax of 5 per cent on dividends being returned to Germany (15 per cent prior to 1992), it does not impose a withholding tax on interest. Neither the UK nor France withholds tax on dividend or interest payments made to Germany 42 The EMTR is still higher than the EATR, although both decline.

The final column of Table F.3 shows the average tax rate calculated using data from company accounts, where the tax rate for each firm is defined as the ratio of provision for tax to net pre-tax income and the median of those tax rates is presented here. The ATR falls from a high of 43 per cent in 1986 to 27 per cent in 1994, with one slight increase in 1990.

The standard deviation on inward investment rises, both for the EMTR and the EATR. This indicates a decrease in the degree of capital import neutrality in Germany. The evidence for outward investment is less clear. The EMTR indicates an increase in the degree of capital export neutrality (CEN) but the EATR, considered over the entire period, shows a decline in the degree of CEN. However, the EATR from 1981 until the end of the period shows an increase in CEN. The rise in the standard deviation between 1980 and 1981 is due to the dramatic reduction of the statutory tax rate in Ireland (the EATR on investment from Germany to Ireland falls from 21 per cent to -5.5 per cent), despite Ireland's small weight in the outward EATR (around 2 per cent).

\footnotetext{
${ }^{42}$ However, unlike its treatment of many European countries, the UK does not grant the dividend tax credit for dividends remitted to Germany.
} 


\section{Germany}

\section{FIGURE F.1}

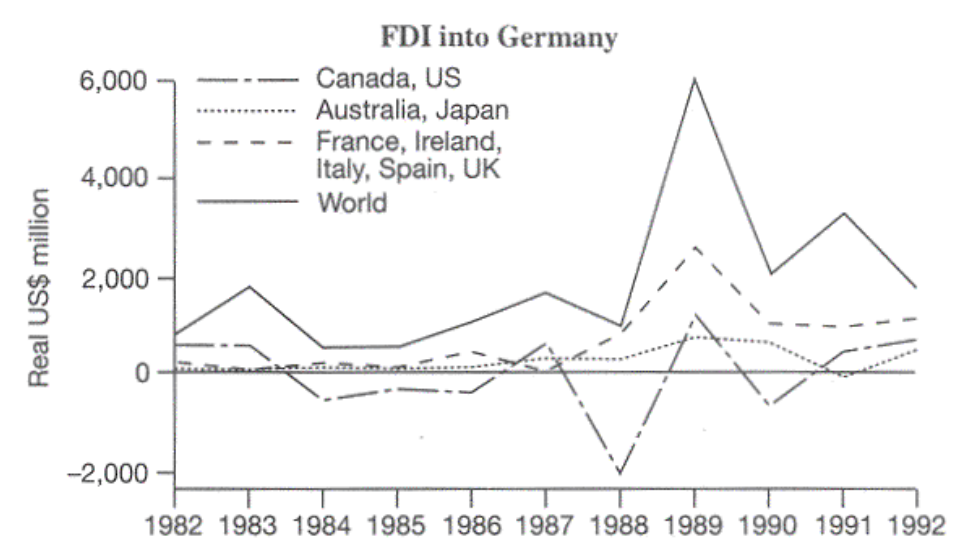

Sources: OECD International Direct Investment Statistics 1982-1993 database: exchange rate and US GDP deflator from OECD Economic Outlook.

\section{FIGURE F.2}

\section{FDI from Germany}

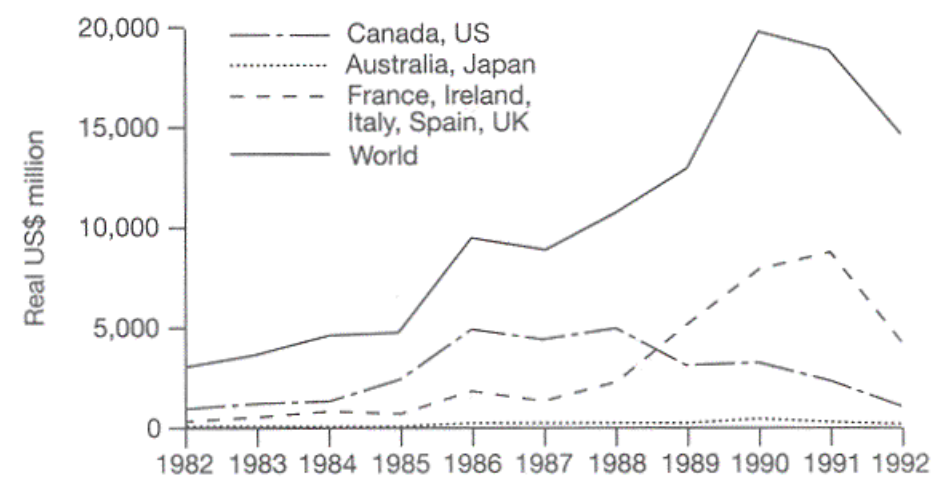

Sources: OECD International Direct Investment Statistics 1982-1993 database: exchange rate and US GDP deflator from OECD Economic Outlook.

Figures F.1 and F.2 show the total amounts of foreign direct investment, both into and out of Germany, measured in millions of 1985 US dollars. For ease of presentation, the sources and destinations of the FDI 
Taxing profits in a changing world

have been broken down by geographic region of the countries covered in the study: Europe excluding Germany, North America and a separate group for Australia and Japan. A total for the world is also given (this includes all countries, not just those covered in this study). The absolute level of FDI into Germany has been volatile over time, with large negative inflow of FDI from the US (i.e. repatriation of FDI) during some years. FDI out of Germany rose gradually until 1990, before falling off slightly. Much of this investment has been in other European countries, with the amount going to Canada and the US declining over time. 


\section{APPENDIX G \\ Ireland}

Ireland has introduced a number of special schemes over the years designed to encourage inward investment. ${ }^{43} \mathrm{~A}$ reduced rate of corporate income tax (10 per cent) for manufacturing firms was introduced in 1981 and applies until 2010.44 Prior to 1988 , the full cost of investment in industrial buildings or plant and machinery could be written off in the first year. These accelerated allowances were gradually reduced to zero in 1992, which coincided with an adjustment to the overall allowance structure. The amount of tax revenue collected from corporate income taxes, both as a percentage of GDP and as a percentage of total tax revenue, fell off in the late $1980 \mathrm{~s}$, but has since risen substantially.

Table G. 2 shows the effective marginal tax wedge for domestic investment, broken down by asset and by type of finance. The overall effective marginal tax wedge has increased by 1 percentage point during the period, reflecting both the reduction in the tax subsidy for investment financed by debt as the corporate tax rate fell, and a reduction in the value of allowances on investment in plant and machinery and investment in buildings. The fall in the tax wedge on inventories was caused by a fall in the statutory rate.

\footnotetext{
${ }^{43}$ For example, until 1990 profits on the export of goods from Ireland were exempt from tax. This is not modelled here.

${ }^{44}$ Current proposals exist for a single corporate tax rate of $12.5 \%$ for trading profits (25\% for non-trading profits), to be introduced in 2011 for companies currently liable at the $10 \%$ rate.
} 
Taxing profits in a changing world

TABLE G.1

Irish tax rates and NPV of allowances

\begin{tabular}{rrrrrrr}
\hline & $\begin{array}{r}\text { Headline } \\
\text { rate }\end{array}$ & $\begin{array}{r}\text { Statutory } \\
\text { rate }^{a}\end{array}$ & $\begin{array}{r}\text { NPVof } \\
\text { allowances } \\
\text { (buildings) }\end{array}$ & $\begin{array}{r}\text { NPVof } \\
\text { allowances } \\
\text { (plant and } \\
\text { machinery) }\end{array}$ & $\begin{array}{r}\text { CT } \\
\text { as of } \\
\text { GDP }\end{array}$ & $\begin{array}{r}\text { CTas a } \\
\% \text { of } \\
\text { total } \\
\text { tax }\end{array}$ \\
\hline 1979 & 45.0 & $45.0(45.0)$ & 1.00 & 1.00 & 1.8 & 5.7 \\
1980 & 45.0 & $45.0(45.0)$ & 1.00 & 1.00 & 1.5 & 4.5 \\
1981 & 10.0 & $10.0(10.0)$ & 1.00 & 1.00 & 1.8 & 5.0 \\
1982 & 10.0 & $10.0(10.0)$ & 1.00 & 1.00 & 1.7 & 4.7 \\
1983 & 10.0 & $10.0(10.0)$ & 1.00 & 1.00 & 1.5 & 3.8 \\
1984 & 10.0 & $10.0(10.0)$ & 1.00 & 1.00 & 1.3 & 3.3 \\
1985 & 10.0 & $10.0(10.0)$ & 1.00 & 1.00 & 1.2 & 3.2 \\
1986 & 10.0 & $10.0(10.0)$ & 1.00 & 1.00 & 1.4 & 3.5 \\
1987 & 10.0 & $10.0(10.0)$ & 1.00 & 1.00 & 1.3 & 3.2 \\
1988 & 10.0 & $10.0(10.0)$ & 0.91 & 0.87 & 1.5 & 3.8 \\
1989 & 10.0 & $10.0(10.0)$ & 0.73 & 0.74 & 1.2 & 3.4 \\
1990 & 10.0 & $10.0(10.0)$ & 0.73 & 0.74 & 1.7 & 5.0 \\
1991 & 10.0 & $10.0(10.0)$ & 0.51 & 0.61 & 2.1 & 5.9 \\
1992 & 10.0 & $10.0(10.0)$ & 0.32 & 0.71 & 2.5 & 6.8 \\
1993 & 10.0 & $10.0(10.0)$ & 0.32 & 0.71 & 3.0 & 8.1 \\
1994 & 10.0 & $10.0(10.0)$ & 0.32 & 0.71 & 3.3 & 8.8 \\
\hline
\end{tabular}

${ }^{a}$ The statutory rate shows, first, the rate on retained earnings and then, in parentheses, the rate on distributed profits.

Note: The special $10 \%$ corporate tax rate applies to companies carrying out manufacturing operations.

Columns 4 to 6 of Table G. 2 show the tax wedge on the three different types of finance (averaged across assets). The operation of the imputation system in Ireland, which grants a tax credit on dividend income, results in a lower tax wedge on new equity than on retained earnings. For retained earnings, the tax wedge initially fell with the introduction of the 10 per cent tax rate, but it increased as the value of capital allowances fell from 1988. For those investments financed by new equity, the tax subsidy reduced as the statutory tax rate fell, and reduced further as accelerated allowances were withdrawn. The tax subsidy on investment financed by debt fell with the statutory rate, since interest payments are deductible from the corporate tax base. 
Ireland

TABLE G.2

Irish domestic effective marginal tax wedge

\begin{tabular}{l|rrr|rrr|r}
\hline & Buildings & $\begin{array}{r}\text { Plant and } \\
\text { machinery }\end{array}$ & Inventory & $\begin{array}{r}\text { Retained } \\
\text { earnings }\end{array}$ & $\begin{array}{r}\text { New } \\
\text { equity }\end{array}$ & Debt & Average \\
& 1 & 2 & 3 & 4 & 5 & 6 & 7 \\
\hline 1979 & -2.5 & -2.5 & 6.4 & 2.4 & -2.3 & -4.7 & -0.6 \\
1980 & -2.5 & -2.5 & 6.4 & 2.4 & -2.3 & -4.7 & -0.6 \\
1981 & -0.5 & -0.5 & 0.9 & 0.3 & -0.4 & -1.0 & -0.2 \\
1982 & -0.5 & -0.5 & 0.9 & 0.3 & -0.4 & -1.0 & -0.2 \\
1983 & -0.5 & -0.5 & 0.9 & 0.3 & -0.4 & -1.0 & -0.2 \\
1984 & -0.5 & -0.5 & 0.9 & 0.3 & -0.4 & -1.0 & -0.2 \\
1985 & -0.5 & -0.5 & 0.9 & 0.3 & -0.4 & -1.0 & -0.2 \\
1986 & -0.5 & -0.5 & 0.9 & 0.3 & -0.4 & -1.0 & -0.2 \\
1987 & -0.5 & -0.5 & 0.9 & 0.3 & -0.4 & -1.0 & -0.2 \\
1988 & -0.4 & -0.2 & 0.9 & 0.5 & -0.2 & -0.9 & 0.0 \\
1989 & -0.2 & 0.1 & 0.9 & 0.8 & 0.0 & -0.7 & 0.2 \\
1990 & -0.2 & 0.1 & 0.9 & 0.8 & 0.0 & -0.7 & 0.2 \\
1991 & 0.2 & 0.4 & 0.9 & 1.0 & 0.3 & -0.4 & 0.4 \\
1992 & 0.4 & 0.1 & 0.9 & 1.0 & 0.2 & -0.5 & 0.4 \\
1993 & 0.4 & 0.1 & 0.9 & 1.0 & 0.2 & -0.5 & 0.4 \\
1994 & 0.4 & 0.1 & 0.9 & 1.0 & 0.2 & -0.5 & 0.4 \\
\hline
\end{tabular}

Notes: Columns 1-3 are weighted averages across types of finance; columns 4-6 are weighted averages across assets; column 7 is a weighted average across both finance and assets. Weights used are: $28 \%$ buildings, $50 \%$ plant and machinery, $22 \%$ inventories; $55 \%$ retained earnings, $10 \%$ new equity, 35\% debt. Inflation and the real interest rate are held constant at $3.5 \%$ and $10 \%$ respectively. See Appendix A for definition and interpretation of variables.

As with the wedge in the final column of Table G.2, the domestic effective marginal tax rate in column 1 of Table G.3 has also increased, though it remains the lowest of the countries considered here. Column 2 shows the effective average tax rate for a domestic investment earning a real rate of return of 40 per cent in the absence of tax. This dropped dramatically in 1981 due to the cut in the statutory rate, but since then has increased by about 1 percentage point. This is a striking example of how changes in the statutory tax rate dominate movements in the EATR, while changes in the definition of allowances have a larger impact on the EMTR than on the EATR. 
Taxing profits in a changing world

TABLE G.3

Irish effective tax rates

\begin{tabular}{|c|c|c|c|c|c|}
\hline & \multicolumn{2}{|c|}{ Domestic } & \multicolumn{2}{|c|}{ Source } & \multirow[b]{2}{*}{$\begin{array}{r}A T R \\
\text { s.d. } \\
5 \\
\end{array}$} \\
\hline & $\begin{array}{r}\text { EMTR } \\
1 \\
\end{array}$ & $\begin{array}{r}E A T R \\
2 \\
\end{array}$ & $\begin{array}{r}E M T R \\
\text { s.d. } \\
3 \\
\end{array}$ & $\begin{array}{r}E A T R \\
\text { s.d. } \\
4 \\
\end{array}$ & \\
\hline 1979 & -5.5 & 19.4 & $\begin{array}{r}14.0 \\
2.6\end{array}$ & $\begin{array}{r}26.2 \\
2.3\end{array}$ & \\
\hline 1980 & -5.5 & 19.4 & $\begin{array}{r}14.0 \\
2.6\end{array}$ & $\begin{array}{r}26.2 \\
2.3\end{array}$ & \\
\hline 1981 & -2.3 & 4.3 & $\begin{array}{l}52.5 \\
29.3\end{array}$ & $\begin{array}{l}18.8 \\
11.1\end{array}$ & \\
\hline 1982 & -2.3 & 4.3 & $\begin{array}{l}52.5 \\
29.3\end{array}$ & $\begin{array}{l}18.8 \\
11.1\end{array}$ & \\
\hline 1983 & -2.3 & 4.3 & $\begin{array}{l}50.3 \\
23.7\end{array}$ & $\begin{array}{l}18.6 \\
10.8\end{array}$ & \\
\hline 1984 & -2.3 & 4.3 & $\begin{array}{l}46.2 \\
14.4\end{array}$ & $\begin{array}{l}18.1 \\
10.4\end{array}$ & \\
\hline 1985 & -2.3 & 4.3 & $\begin{array}{l}43.3 \\
10.9\end{array}$ & $\begin{array}{l}17.7 \\
10.2\end{array}$ & \\
\hline 1986 & -2.3 & 4.3 & $\begin{array}{l}41.1 \\
11.8\end{array}$ & $\begin{array}{l}17.2 \\
10.1\end{array}$ & \\
\hline 1987 & -2.3 & 4.3 & $\begin{array}{r}26.9 \\
4.0\end{array}$ & $\begin{array}{r}13.9 \\
8.5\end{array}$ & \\
\hline 1988 & -0.3 & 4.6 & $\begin{array}{r}29.2 \\
3.8\end{array}$ & $\begin{array}{r}14.3 \\
8.5\end{array}$ & $\begin{array}{l}32.6 \\
16.2\end{array}$ \\
\hline 1989 & 1.9 & 5.0 & $\begin{array}{r}32.1 \\
3.9\end{array}$ & $\begin{array}{r}14.7 \\
8.6\end{array}$ & $\begin{array}{l}48.5 \\
12.0\end{array}$ \\
\hline 1990 & 1.9 & 5.0 & $\begin{array}{r}31.2 \\
5.6\end{array}$ & $\begin{array}{r}15.1 \\
7.0\end{array}$ & $\begin{array}{r}37.2 \\
4.6\end{array}$ \\
\hline 1991 & 4.4 & 5.5 & $\begin{array}{r}34.0 \\
5.2\end{array}$ & $\begin{array}{r}15.4 \\
7.3\end{array}$ & $\begin{array}{r}44.2 \\
4.0\end{array}$ \\
\hline 1992 & 3.9 & 5.4 & $\begin{array}{r}33.6 \\
5.2\end{array}$ & $\begin{array}{r}15.4 \\
7.3\end{array}$ & $\begin{array}{l}34.7 \\
12.8\end{array}$ \\
\hline 1993 & 3.9 & 5.4 & $\begin{array}{r}34.2 \\
6.3\end{array}$ & $\begin{array}{r}15.7 \\
7.1\end{array}$ & $\begin{array}{l}35.4 \\
12.5\end{array}$ \\
\hline 1994 & 3.9 & 5.4 & $\begin{array}{r}33.8 \\
7.5 \\
\end{array}$ & $\begin{array}{r}15.9 \\
6.2 \\
\end{array}$ & \\
\hline
\end{tabular}

Notes: All rates are averaged across finance and assets. Weights used are: $28 \%$ buildings, $50 \%$ plant and machinery, $22 \%$ inventories; $55 \%$ retained earnings, $10 \%$ new equity, $35 \%$ debt. Inflation and the real interest rate are held constant at $3.5 \%$ and $10 \%$ respectively. Columns 3 and 4 are weighted across countries by the proportion of inward FDI coming from each country (see Table A.1). The EATR in columns 2 and 4 is for an investment earning a $40 \%$ real rate of return in the absence of tax. ATR is the average tax rate calculated using firm-level accounting data from Global Vantage. The standard deviations are shown in italics. They measure: in columns 3 and 4, the variation across the nine source countries; and in column 5, the variation across firms resident in Ireland. See Appendix A for definition and interpretation of variables. 
Columns 3 and 4 show the effective tax rates on investment into Ireland. These are weighted averages across the nine other countries, weighted by the proportion of FDI coming from each country (see Table A.1). The EMTR rises significantly in 1981 but declines over the remainder of the period. At first glance, it appears odd that the decrease in the statutory tax rate in 1981 led to an increase in the EMTR on investment into Ireland. This is true even though the two countries that are responsible for the largest amount of investment into Ireland (the US at 73 per cent and the UK at 16 per cent) operate credit systems. The reason relates to the impact upon the discount rate of a difference between the tax rate on profits retained in the company and that on profits distributed to shareholders. ${ }^{45}$ The EATR on inward investment, however, falls due to the 1981 reduction in the tax rate and then continues to fall over the remainder of the period.

Data on outward FDI flows from Ireland are not available; therefore residence EMTRs and EATRs have not been presented. The final column of Table G.3 shows the average tax rate calculated using data from

\footnotetext{
${ }^{45}$ Consider an investment from the UK into Ireland that is financed by retained earnings in the parent and new equity in the subsidiary (assume a fixed exchange rate). The EMTR on this investment will be affected by the value of several parameters (see Appendix A for relevant formulas). In 1980 and 1981, the tax discrimination parameter $\gamma=1.43$ in the UK. The statutory tax rate on retained earnings in Ireland was $\tau_{n}^{r}=0.45$ in 1980 and fell to $\tau_{n}^{r}=0.10$ in 1981. This meant that the effective tax charge on dividend payments by the subsidiary to the parent was $\sigma^{* \prime}=0.127$ in 1980 and $\sigma^{* \prime}=0.467$ in 1981. Assuming a real interest rate of $10 \%$ and inflation of $3.5 \%$ in both countries, the nominal interest rate would be $i_{j}=0.1385$. Therefore the discount rate went from $\rho^{\prime}=0.169$ in 1980 to $\rho^{\prime}=0.417$ in 1981 . This led to an increase in the cost of capital caused by a decrease in the rate of taxation of dividends in Ireland.
} 
Taxing profits in a changing world

company accounts, where the tax rate for each firm is defined as the ratio of provision for tax to net pre-tax income and the median of those tax rates is presented here. The ATR ranges from 32 to 48 per cent. However, note that these rates are calculated from only a few companies' accounting data (see Table A.6).

\section{FIGURE G.1}

FDI into Ireland

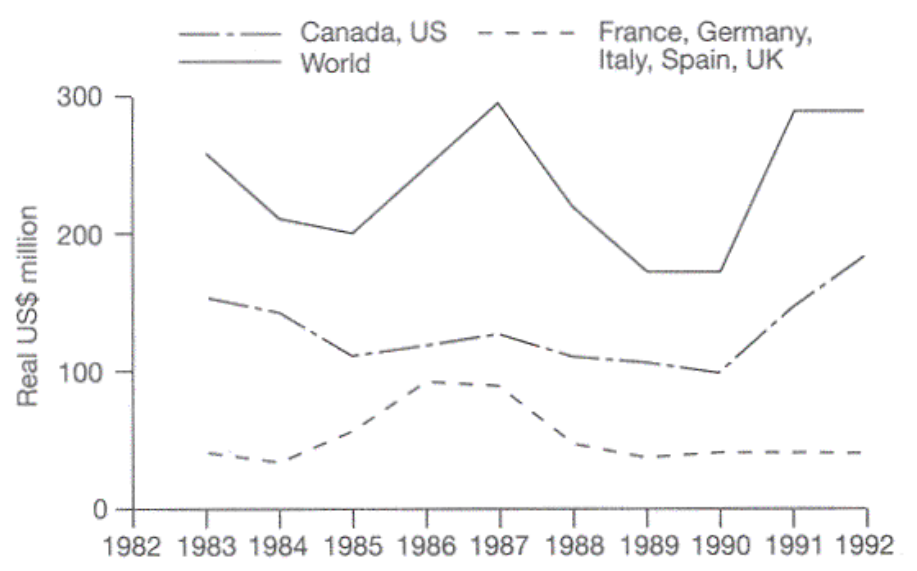

Sources: OECD International Direct Investment Statistics 1982-1993 database; exchange rate and US GDP deflator from OECD Economic Outlook.

The standard deviation on inward investment into Ireland rose dramatically due to the 1981 reform but has fallen since then (dramatically in the case of the EMTR). This indicates that the degree of capital import neutrality in Ireland has increased over the period 198194.

Figure G.1 shows the total amount of foreign direct investment into Ireland, measured in millions of 1985 US dollars. For ease of presentation, the source of the FDI has been broken down by geographic region of the countries covered in the study: Europe excluding Ireland, and North America. A total for the world is also given (this includes all countries, not just those covered 
Ireland

in this study). Absolute levels of FDI into Ireland rose over the mid-1980s, fell off in the late 1980s, but began to increase again after 1990. Canada and the US have been a dominant factor of this external investment in Ireland. 


\section{APPENDIX H \\ Italy}

Italy raised its headline rate of corporate income tax, from 25 per cent in 1979 to 36 per cent in 1984, while decreasing the generosity of depreciation allowances on investments in buildings and plant and machinery. As a result, the overall tax wedge has increased from around zero to 2.5, as shown in the final column of Table H.2. Corporation tax receipts have grown as a proportion of GDP, from 2.5 per cent to about 4 per cent, and as a proportion of total tax receipts, from about 8 per cent to 10 per cent, although they fell back again in 1994.

TABLE H.1

Italian tax rates and NPV of allowances

\begin{tabular}{rrrrrrr}
\hline $\begin{array}{r}\text { Headline } \\
\text { rate }\end{array}$ & $\begin{array}{r}\text { Statutory } \\
\text { rate }^{a}\end{array}$ & $\begin{array}{r}\text { NPVof } \\
\text { allowances } \\
\text { (buildings) }\end{array}$ & $\begin{array}{r}\text { NPV of } \\
\text { allowances } \\
\text { (plant and } \\
\text { machinery) }\end{array}$ & $\begin{array}{r}\text { CT } \\
\text { as a of } \\
\text { GDP }\end{array}$ & $\begin{array}{r}\text { CT as } a \\
\% \text { of } \\
\text { total } \\
\text { tax }\end{array}$ \\
\hline 1979 & 25.0 & $36.3(25.0)$ & 0.67 & 0.84 & 2.5 & 8.3 \\
1980 & 25.0 & $36.3(25.0)$ & 0.67 & 0.84 & 2.4 & 7.8 \\
1981 & 25.0 & $36.3(25.0)$ & 0.67 & 0.84 & 2.6 & 8.3 \\
1982 & 25.0 & $38.8(27.0)$ & 0.67 & 0.84 & 3.0 & 8.8 \\
1983 & 30.0 & $41.3(30.0)$ & 0.67 & 0.84 & 3.2 & 9.0 \\
1984 & 36.0 & $46.4(36.0)$ & 0.67 & 0.84 & 3.4 & 9.8 \\
1985 & 36.0 & $46.4(36.0)$ & 0.67 & 0.84 & 3.2 & 9.2 \\
1986 & 36.0 & $46.4(36.0)$ & 0.67 & 0.84 & 3.8 & 10.6 \\
1987 & 36.0 & $46.4(36.0)$ & 0.67 & 0.84 & 3.8 & 10.5 \\
1988 & 36.0 & $46.4(36.0)$ & 0.42 & 0.81 & 3.4 & 9.4 \\
1989 & 36.0 & $46.4(36.0)$ & 0.42 & 0.81 & 3.8 & 10.0 \\
1990 & 36.0 & $46.4(36.0)$ & 0.38 & 0.76 & 3.9 & 10.0 \\
1991 & 36.0 & $47.8(36.0)$ & 0.38 & 0.76 & 3.8 & 9.6 \\
1992 & 36.0 & $47.8(36.0)$ & 0.38 & 0.76 & 4.4 & 10.4 \\
1993 & 36.0 & $52.2(36.0)$ & 0.38 & 0.76 & 4.1 & 9.3 \\
1994 & 36.0 & $53.2(37.0)$ & 0.38 & 0.76 & 3.7 & 8.9 \\
\hline
\end{tabular}

${ }^{\mathrm{a}}$ The statutory rate shows, first, the rate on retained earnings and then, in parentheses, the rate on distributed profits. It includes the local corporate income tax, which changes from being deductible to non-deductible between 1990 and 1993. Surcharges are imposed in 1982 and 1994. 
TABLE H.2

Italian domestic effective marginal tax wedge

\begin{tabular}{l|rrr|rrr|r}
\hline & Buildings & $\begin{array}{r}\text { Plant and } \\
\text { machinery }\end{array}$ & Inventory & $\begin{array}{r}\text { Retained } \\
\text { earnings }\end{array}$ & $\begin{array}{r}\text { New } \\
\text { equity }\end{array}$ & Debt & Average \\
& 1 & 2 & 3 & 4 & 5 & 6 & 7 \\
\hline 1979 & -0.2 & -0.6 & 2.3 & 3.0 & -3.3 & -3.3 & 0.1 \\
1980 & -0.2 & -0.6 & 2.3 & 3.0 & -3.3 & -3.3 & 0.1 \\
1981 & -0.2 & -0.6 & 2.3 & 3.0 & -3.3 & -3.3 & 0.1 \\
1982 & -0.2 & -0.6 & 2.6 & 3.3 & -3.3 & -3.6 & 0.2 \\
1983 & -0.1 & -0.5 & 2.9 & 3.7 & -3.1 & -3.9 & 0.3 \\
1984 & 0.0 & -0.6 & 3.4 & 4.5 & -4.5 & -4.5 & 0.5 \\
1985 & 0.0 & -0.6 & 3.4 & 4.5 & -4.5 & -4.5 & 0.5 \\
1986 & 0.0 & -0.6 & 3.4 & 4.5 & -4.5 & -4.5 & 0.5 \\
1987 & 0.0 & -0.6 & 3.4 & 4.5 & -4.5 & -4.5 & 0.5 \\
1988 & 2.2 & -0.1 & 3.4 & 5.6 & -4.0 & -4.0 & 1.3 \\
1989 & 2.2 & -0.1 & 3.4 & 5.6 & -4.0 & -4.0 & 1.3 \\
1990 & 2.6 & 0.6 & 3.4 & 6.2 & -3.7 & -3.7 & 1.8 \\
1991 & 2.7 & 0.7 & 3.6 & 6.6 & -3.8 & -3.8 & 1.9 \\
1992 & 2.7 & 0.7 & 3.6 & 6.6 & -3.8 & -3.8 & 1.9 \\
1993 & 3.3 & 1.0 & 4.3 & 7.9 & -4.3 & -4.3 & 2.4 \\
1994 & 3.5 & 1.1 & 4.5 & 8.2 & -4.3 & -4.4 & 2.5 \\
\hline
\end{tabular}

Notes: Columns 1-3 are weighted averages across types of finance; columns 4-6 are weighted averages across assets; column 7 is a weighted average across both finance and assets. Weights used are: $28 \%$ buildings, $50 \%$ plant and machinery, $22 \%$ inventories; $55 \%$ retained earnings, $10 \%$ new equity, 35\% debt. Inflation and the real interest rate are held constant at 3.5\% and 10\% respectively. See Appendix A for definition and interpretation of variables.

Table H.2 shows the effective marginal tax wedge for domestic investment, broken down by asset and by type of finance. The tax wedge on all types of investment increases during the period, particularly for investment in buildings, which increases from zero to 3.5. This is due to a reduction in the generosity of depreciation allowances after 1988. Until 1988, companies were allowed an additional 15 per cent allowance in the first three years. This was limited to a double allowance by 1990, and restricted to only 7.5 per cent in the first year. By contrast, there was a small increase in the subsidy given to two types of finance - new equity and debt as a result of the increase in the statutory tax rate.

As with the wedge in the final column of Table H.2, the domestic effective marginal tax rate in the first 


\section{Taxing profits in a changing world}

column of Table H.3 has increased over the period, in particular after the change in depreciation allowances in 1988. Column 2 shows the effective average tax rate for a domestic investment earning a real rate of return of 40 per cent in the absence of tax. The effective average tax rate has also increased, by 6 percentage points, largely driven by the increase in the statutory rate of tax.

Columns 3 and 4 show the effective tax rates on investment into Italy. These are weighted averages across the nine other countries, weighted by the proportion of FDI coming from each country (see Table A.1). Between 1982 and 1992, just over one-third of inward investment to Italy (performed by countries in this study) came from France, one-quarter from the US, 20 per cent from the UK and 11 per cent from Germany. Italy imposed a withholding tax on interest income of 15 per cent on these countries (zero for Germany, and reduced to 10 per cent in 1994 for France and the UK). Dividend income also faced a withholding tax, of 5 per cent for the UK and the US, with higher rates for most of the period for France and Germany. The weighted effective marginal tax rate has fluctuated, but ended the period significantly lower than it started. The EATR on inward investment has remained fairly stable over time.

The fifth and sixth columns of Table H.3 show the effective tax rates for Italian companies investing abroad. The pattern seen for outward FDI is quite similar to that for inward FDI, with the US and France each receiving over one-quarter of outward Italian investment. The UK receives 16 per cent, Germany and Spain about 10 per cent. The US and France imposed withholding taxes on interest income paid to Italy, at 30 per cent and 15 per cent respectively before 1987, when they fell to 15 per cent and zero. Prior to 1993, France imposed a withholding tax of 15 per cent on dividend 
Italy

TABLE H.3

Italian effective tax rates

\begin{tabular}{|c|c|c|c|c|c|c|c|}
\hline & \multicolumn{2}{|c|}{ Domestic } & \multicolumn{2}{|c|}{ Source } & \multicolumn{3}{|c|}{ Residence } \\
\hline & EMTR & EATR & EMTR & EATR & EMTR & EATR & $A T R$ \\
\hline & & & s.d. & s.d. & s.d. & s.d. & s.d. \\
\hline & 1 & 2 & 3 & 4 & 5 & 6 & 7 \\
\hline \multirow[t]{2}{*}{1979} & 1.3 & 13.0 & 35.0 & 22.2 & 35.3 & 28.6 & \\
\hline & & & 19.3 & 5.1 & 21.2 & 4.1 & \\
\hline \multirow[t]{2}{*}{1980} & 1.3 & 13.0 & 34.7 & 22.1 & 34.0 & 28.5 & \\
\hline & & & 19.4 & 5.2 & 21.9 & 4.2 & \\
\hline \multirow[t]{2}{*}{1981} & 1.3 & 13.0 & 34.7 & 22.0 & 31.6 & 28.2 & \\
\hline & & & 19.5 & 5.2 & 21.5 & 4.2 & \\
\hline \multirow[t]{2}{*}{1982} & 2.2 & 14.0 & 34.1 & 22.8 & 32.7 & 28.4 & \\
\hline & & & 20.5 & 4.9 & 21.6 & 4.2 & \\
\hline \multirow[t]{2}{*}{1983} & 3.4 & 15.1 & 32.0 & 23.3 & 33.0 & 28.4 & \\
\hline & & & 19.7 & 4.0 & 21.4 & 4.5 & \\
\hline \multirow[t]{2}{*}{1984} & 4.7 & 15.8 & 28.9 & 24.3 & 39.9 & 28.7 & \\
\hline & & & 20.6 & 3.1 & 17.4 & 4.0 & \\
\hline \multirow[t]{2}{*}{1985} & 4.7 & 15.8 & 27.2 & 23.7 & 41.9 & 28.8 & \\
\hline & & & 22.0 & 3.5 & 14.3 & 3.8 & \\
\hline \multirow[t]{2}{*}{1986} & 4.7 & 15.8 & 26.7 & 24.1 & 51.7 & 29.5 & \\
\hline & & & 22.8 & 3.4 & 22.6 & 4.1 & \\
\hline \multirow[t]{2}{*}{1987} & 4.7 & 15.8 & 22.5 & 22.9 & 51.8 & 28.5 & 42.8 \\
\hline & & & 23.4 & 3.1 & 8.6 & 2.8 & 9.4 \\
\hline \multirow[t]{2}{*}{1988} & 13.2 & 17.0 & 31.8 & 24.2 & 50.9 & 28.0 & 42.3 \\
\hline & & & 25.0 & 3.1 & 7.9 & 2.0 & 14.9 \\
\hline \multirow[t]{2}{*}{1989} & 13.2 & 17.0 & 31.5 & 24.3 & 53.2 & 28.0 & 30.8 \\
\hline & & & 24.8 & 3.0 & 9.7 & 2.1 & 13.8 \\
\hline \multirow[t]{2}{*}{1990} & 17.9 & 17.6 & 34.4 & 25.1 & 56.2 & 28.4 & 29.6 \\
\hline & & & 19.6 & 3.1 & 9.5 & 2.2 & 13.0 \\
\hline \multirow[t]{2}{*}{1991} & 19.2 & 18.0 & 33.8 & 25.2 & 62.8 & 28.6 & 28.7 \\
\hline & & & 19.1 & 3.0 & 18.8 & 2.8 & 11.7 \\
\hline \multirow[t]{2}{*}{1992} & 19.2 & 18.0 & 32.9 & 24.6 & 58.8 & 28.0 & 35.2 \\
\hline & & & 19.4 & 3.2 & 15.6 & 2.4 & 5.5 \\
\hline \multirow[t]{2}{*}{1993} & 24.0 & 18.8 & 22.8 & 21.6 & 95.7 & 31.4 & 29.6 \\
\hline & & & 9.5 & 3.9 & 30.0 & 3.1 & 7.6 \\
\hline \multirow[t]{2}{*}{1994} & 25.4 & 19.2 & 23.6 & 22.3 & 110.1 & 32.6 & 20.9 \\
\hline & & & 9.1 & 3.4 & 33.9 & 2.8 & 22.3 \\
\hline
\end{tabular}

Notes: All rates are averaged across finance and assets. Weights used are: $28 \%$ buildings, $50 \%$ plant and machinery, $22 \%$ inventories; $55 \%$ retained earnings, $10 \%$ new equity, $35 \%$ debt. Inflation and the real interest rate are held constant at $3.5 \%$ and $10 \%$ respectively. Columns 3 and 4 are weighted across countries by the proportion of inward FDI coming from each country (see Table A.1). Columns 5 and 6 are weighted across countries by the proportion of outward FDI going to each country (see Table A.2). The EATR in columns 2, 4 and 6 is for an investment earning a $40 \%$ real rate of return in the absence of tax. ATR is the average tax rate calculated using firm-level accounting data from Global Vantage. The standard deviations are shown in italics. They measure: in columns 3 and 4 , the variation across the nine source countries; in columns 5 and 6 , the variation across the nine residence countries; and in column 7, the variation across firms resident in Italy. See Appendix A for definition and interpretation of variables. 


\section{Taxing profits in a changing world}

payments (but granted the imputation credit from 1993 to Italian companies), while the US imposed a 5 per cent rate. Italy operates a credit system for foreign source income. The effective marginal rate for Italian multinationals investing abroad is similar to that for other countries investing in Italy at the start of the period, but much higher than that for a domestic investment. The EMTR for Italian companies investing abroad increases dramatically in the last few years, while the effective average tax rate facing Italian companies investing abroad is only slightly higher at the end of the period than at the beginning.

The final column of Table H.3 shows the average tax rate calculated using data from company accounts, where the tax rate for each firm is defined as the ratio of provision for tax to net pre-tax income and the median of those tax rates is presented here. Information from Italian company accounts is only available in the Global Vantage dataset from 1987 onwards. The ATR halves during the period, although the variation in individual company tax rates is more marked in the final year.

The standard deviation on both the inward EMTR and the inward EATR declines over the period, indicating some increase in the degree of capital import neutrality for investment into Italy. The same is not true for outward investment.

Figures H.1 and H.2 show the total amounts of foreign direct investment, both into and out of Italy, measured in millions of 1985 US dollars. For ease of presentation, the sources and destinations of the FDI have been broken down by geographic region of the countries covered in the study: Europe excluding Italy, North America and a separate group for Australia and Japan. A total for the world is also given (this includes all countries, not just those covered in this study). The level of investment into Italy has fluctuated 
dramatically, with a significant fall in the real level in 1989 , mirrored by a fall in Italian investment abroad in that year.

FIGURE H. 1

FDI into Italy

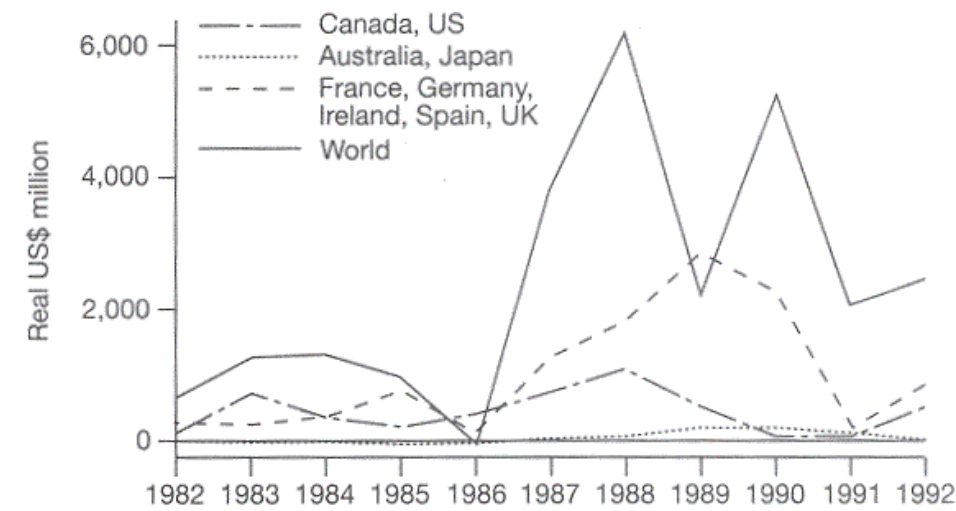

Sources: OECD International Direct Investment Statistics 1982-1993 database: exchange rate and US GDP deflator from OECD Economic Outlook.

FIGURE H.2

FDI from Italy

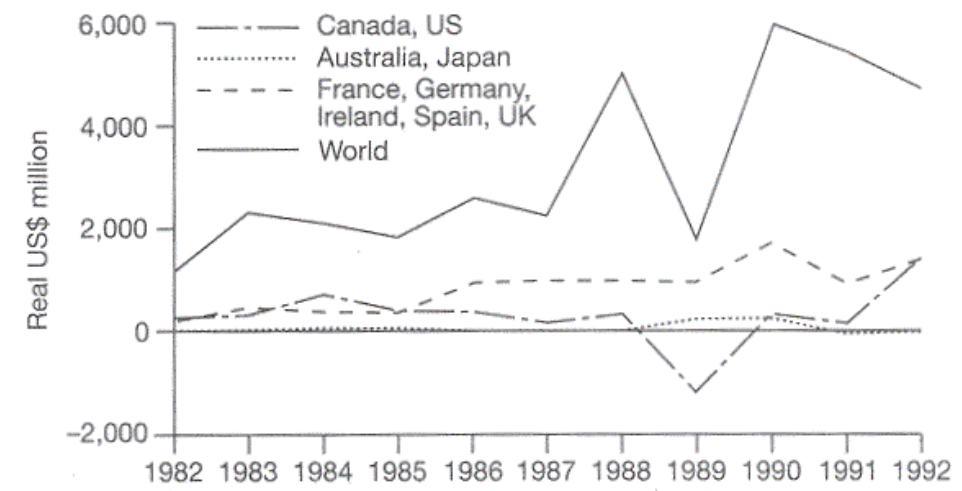

Sources: OECD International Direct Investment Statistics 1982-1993 database: exchange rate and US GDP deflator from OECD Economic Outlook. 
APPENDIX I

Japan

Japan has, throughout the period, maintained one of the highest tax rates, under almost any of the measures considered (see below). The statutory corporate income tax rate in Japan is made up of a number of taxes, shown in Table I.1. The national corporate income tax rate is what is denoted as the headline rate. Until 1991, Japan operated a split-rate system, with the statutory rate on distributed profits lower than that on retained earnings. The underlying headline rates of tax on retained and distributed earnings have gradually equalised, through the rise in the latter. There are two local taxes to account for: the 'enterprise tax' and the 'inhabitants tax'. The enterprise tax is deductible (from the income base that it is calculated on), while the inhabitants tax is not. The enterprise tax applies to corporate income and depends upon the size of the firm; the standard rate in the highest income range is used here (12 per cent). The inhabitants tax applies to the firm's corporate income tax liability, and ranges from 5 per cent to 20.7 per cent. Table I.1 uses the lowest rate for Tokyo (17.3 per cent).

The statutory rate of corporate income tax on retained earnings in Japan, including the local taxes described above, rose slightly in the mid-1980s, then fell back by the end of the period. There have been very few changes to depreciation allowances.

The amount of revenue collected from corporation tax as a percentage of GDP rose until the late 1980s and then fell below its 1979 level. Corporate income tax as a 
TABLE I.1

Composition of Japanese statutory corporate income tax rate

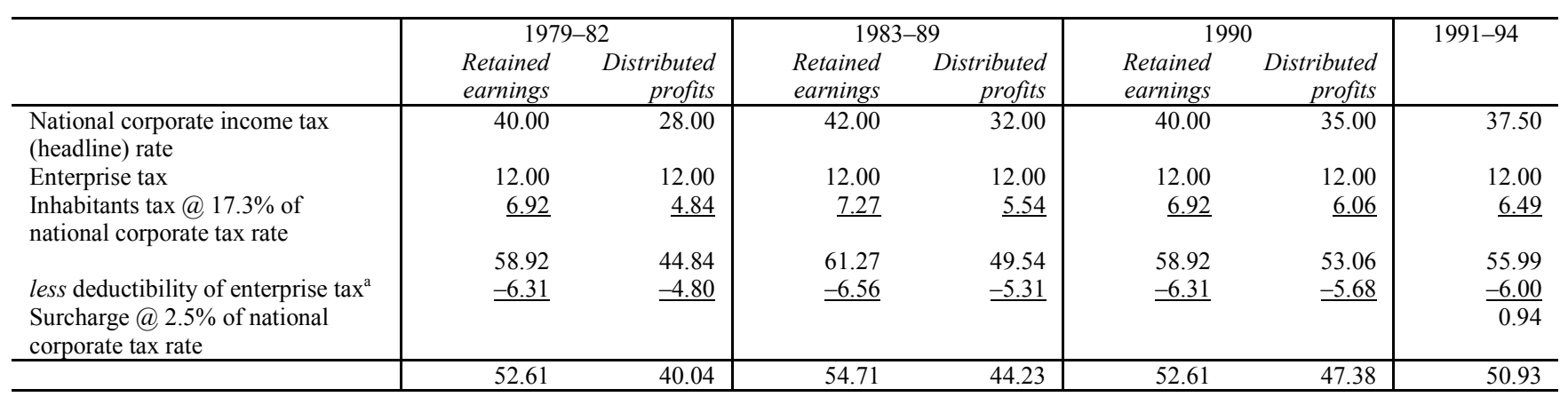

${ }^{\mathrm{a}}$ The enterprise tax is calculated on a tax-exclusive base so the deductibility from the corporate income for the purpose of corporate income tax is worth $100 \bullet 0.12 / 1.12=10.71 \%$ of the rate before deductibility. 
Taxing profits in a changing world

TABLE I.2

Japanese tax rates and NPV of allowances

\begin{tabular}{rrrrrrr}
\hline & $\begin{array}{r}\text { Headline } \\
\text { rate }\end{array}$ & $\begin{array}{r}\text { Statutory } \\
\text { rate }\end{array}$ & $\begin{array}{r}\text { NPV of } \\
\text { allowances } \\
\text { (buildings) }\end{array}$ & $\begin{array}{r}\text { NPV of } \\
\text { allowances } \\
\text { plant and } \\
\text { machinery) }\end{array}$ & $\begin{array}{r}\text { CT } \\
\text { as a of } \\
\text { GDP }\end{array}$ & $\begin{array}{r}\text { CT as a } \\
\% \text { of } \\
\text { total } \\
\text { tax }\end{array}$ \\
\hline 1979 & 40.0 & $52.6(40.0)$ & 0.29 & 0.70 & 5.2 & 20.8 \\
1980 & 40.0 & $52.6(40.0)$ & 0.29 & 0.70 & 5.6 & 21.8 \\
1981 & 40.0 & $52.6(40.0)$ & 0.29 & 0.70 & 5.3 & 20.3 \\
1982 & 40.0 & $52.6(40.0)$ & 0.29 & 0.70 & 5.3 & 19.8 \\
1983 & 42.0 & $54.7(44.2)$ & 0.30 & 0.70 & 5.3 & 19.6 \\
1984 & 42.0 & $54.7(44.2)$ & 0.30 & 0.70 & 5.8 & 21.1 \\
1985 & 42.0 & $54.7(44.2)$ & 0.30 & 0.70 & 5.9 & 21.0 \\
1986 & 42.0 & $54.7(44.2)$ & 0.30 & 0.70 & 6.0 & 20.7 \\
1987 & 42.0 & $54.7(44.2)$ & 0.30 & 0.70 & 6.9 & 23.0 \\
1988 & 42.0 & $54.7(44.2)$ & 0.30 & 0.70 & 7.5 & 24.7 \\
1989 & 42.0 & $54.7(44.2)$ & 0.30 & 0.70 & 7.5 & 24.3 \\
1990 & 40.0 & $52.6(47.4)$ & 0.30 & 0.70 & 6.8 & 21.6 \\
1991 & 37.5 & $50.9(50.9)$ & 0.30 & 0.70 & 6.2 & 20.0 \\
1992 & 37.5 & $50.9(50.9)$ & 0.30 & 0.70 & 5.0 & 17.3 \\
1993 & 37.5 & $50.9(50.9)$ & 0.30 & 0.70 & 4.3 & 14.9 \\
1994 & 37.5 & $50.9(50.9)$ & 0.30 & 0.70 & 4.1 & 14.8 \\
\hline
\end{tabular}

${ }^{\mathrm{a}}$ The statutory rate shows, first, the rate on retained earnings and then, in parentheses, the rate on distributed profits. It includes local taxes as described in the text and a surcharge of $2.5 \%$ from 1991 to 1994.

percentage of total tax revenue shows a similar pattern. Both of these proportions are the highest of the countries considered here (and high relative to the other OECD countries), though by 1994 Australia had risen to around the Japanese level.

Table I. 3 shows the effective marginal tax wedge for domestic investment, broken down by asset and by type of finance. The tax wedge on all types of investment increases slightly during the period, reflecting the changes in tax rates. As would be expected from the increase in the tax rate on distributed earnings, the tax wedge on new equity increases by nearly 5 percentage points, whilst the other types of finance remain relatively unaffected. As a result, the final column 
TABLE I.3

Japanese domestic effective marginal tax wedge

\begin{tabular}{l|rrr|rrr|r}
\hline & Buildings & $\begin{array}{r}\text { Plant and } \\
\text { machinery }\end{array}$ & Inventory & $\begin{array}{r}\text { Retained } \\
\text { earnings }\end{array}$ & $\begin{array}{r}\text { New } \\
\text { equity }\end{array}$ & Debt & Average \\
& 1 & 2 & 3 & 4 & 5 & 6 & 7 \\
\hline 1979 & 5.3 & 3.0 & 5.3 & 9.2 & 4.0 & -3.6 & 4.2 \\
1980 & 5.3 & 3.0 & 5.3 & 9.2 & 4.0 & -3.6 & 4.2 \\
1981 & 5.3 & 3.0 & 5.3 & 9.2 & 4.0 & -3.6 & 4.2 \\
1982 & 5.3 & 3.0 & 5.3 & 9.2 & 4.0 & -3.6 & 4.2 \\
1983 & 5.8 & 3.4 & 5.9 & 9.9 & 5.0 & -3.9 & 4.6 \\
1984 & 5.8 & 3.4 & 5.9 & 9.9 & 5.0 & -3.9 & 4.6 \\
1985 & 5.8 & 3.4 & 5.9 & 9.9 & 5.0 & -3.9 & 4.6 \\
1986 & 5.8 & 3.4 & 5.9 & 9.9 & 5.0 & -3.9 & 4.6 \\
1987 & 5.8 & 3.4 & 5.9 & 9.9 & 5.0 & -3.9 & 4.6 \\
1988 & 5.8 & 3.4 & 5.9 & 9.9 & 5.0 & -3.9 & 4.6 \\
1989 & 5.8 & 3.4 & 5.9 & 9.9 & 5.0 & -3.9 & 4.6 \\
1990 & 5.5 & 3.3 & 5.6 & 9.1 & 6.7 & -3.6 & 4.4 \\
1991 & 5.4 & 3.2 & 5.5 & 8.6 & 8.6 & -3.5 & 4.4 \\
1992 & 5.4 & 3.2 & 5.5 & 8.6 & 8.6 & -3.5 & 4.4 \\
1993 & 5.4 & 3.2 & 5.5 & 8.6 & 8.6 & -3.5 & 4.4 \\
1994 & 5.4 & 3.2 & 5.5 & 8.6 & 8.6 & -3.5 & 4.4 \\
\hline
\end{tabular}

Notes: Columns 1-3 are weighted averages across types of finance; columns 4-6 are weighted averages across assets; column 7 is a weighted average across both finance and assets. Weights used are: $28 \%$ buildings, $50 \%$ plant and machinery, $22 \%$ inventories; $55 \%$ retained earnings, $10 \%$ new equity, 35\% debt. Inflation and the real interest rate are held constant at $3.5 \%$ and $10 \%$ respectively. See Appendix A for definition and interpretation of variables.

shows that the overall tax wedge does not change dramatically over time, but increases slightly.

As with the wedge in the final column of Table I.3, the domestic effective marginal tax rate in the first column of Table I.4 has increased over the period, although not dramatically. Column 2 shows the effective average tax rate for a domestic investment earning a real rate of return of 40 per cent in the absence of tax, which has also increased slightly.

Columns 3 and 4 show the effective tax rates on investment into Japan. These are weighted averages across the nine other countries, weighted by the proportion of FDI coming from each country (see Table A.1). From 1982 to 1992, over 70 per cent of 
Taxing profits in a changing world

investment

TABLE I.4

Japanese effective tax rates

\begin{tabular}{|c|c|c|c|c|c|c|c|}
\hline & \multicolumn{2}{|c|}{ Domestic } & \multicolumn{2}{|c|}{ Source } & \multicolumn{3}{|c|}{ Residence } \\
\hline & EMTR & EATR & EMTR & EATR & EMTR & EATR & $A T R$ \\
\hline & & & s.d. & s.d. & s.d. & s.d. & s.d. \\
\hline & 1 & 2 & 3 & 4 & 5 & 6 & 7 \\
\hline \multirow[t]{2}{*}{1979} & 41.8 & 24.1 & 51.9 & 27.8 & 43.5 & 30.3 & \\
\hline & & & 6.5 & 4.1 & 15.3 & 2.3 & \\
\hline \multirow[t]{2}{*}{1980} & 41.8 & 24.1 & 51.9 & 27.8 & 43.5 & 30.3 & \\
\hline & & & 6.5 & 4.1 & 15.3 & 2.3 & \\
\hline \multirow[t]{2}{*}{1981} & 41.8 & 24.1 & 51.9 & 27.8 & 39.5 & 29.8 & \\
\hline & & & 6.6 & 4.1 & 17.1 & 2.5 & \\
\hline \multirow[t]{2}{*}{1982} & 41.8 & 24.1 & 51.9 & 27.8 & 38.3 & 29.7 & \\
\hline & & & 6.6 & 4.1 & 14.1 & 2.0 & \\
\hline \multirow[t]{2}{*}{1983} & 46.2 & 24.8 & 53.6 & 28.3 & 40.0 & 29.6 & \\
\hline & & & 5.3 & 3.2 & 12.8 & 2.1 & \\
\hline \multirow[t]{2}{*}{1984} & 46.2 & 24.8 & 53.4 & 28.3 & 41.8 & 29.6 & \\
\hline & & & 5.6 & 3.2 & 9.3 & 2.0 & \\
\hline \multirow[t]{2}{*}{1985} & 46.2 & 24.8 & 53.2 & 28.3 & 43.5 & 29.6 & 47.5 \\
\hline & & & 5.8 & 3.2 & 9.9 & 2.0 & 13.9 \\
\hline \multirow[t]{2}{*}{1986} & 46.2 & 24.8 & 52.9 & 28.3 & 46.5 & 29.8 & 48.9 \\
\hline & & & 6.1 & 3.2 & 15.1 & 2.3 & 15.1 \\
\hline \multirow[t]{2}{*}{1987} & 46.2 & 24.8 & 51.3 & 29.0 & 66.0 & 30.9 & 48.9 \\
\hline & & & 5.3 & 3.7 & 6.5 & 1.9 & 14.6 \\
\hline \multirow[t]{2}{*}{1988} & 46.2 & 24.8 & 50.9 & 29.1 & 66.4 & 30.6 & 47.1 \\
\hline & & & 4.3 & 3.7 & 5.9 & 1.1 & 13.5 \\
\hline \multirow[t]{2}{*}{1989} & 46.2 & 24.8 & 50.9 & 29.1 & 67.0 & 30.7 & 45.8 \\
\hline & & & 4.2 & 3.7 & 6.6 & 1.2 & 13.2 \\
\hline \multirow[t]{2}{*}{1990} & 44.2 & 24.7 & 55.1 & 30.7 & 57.8 & 29.4 & 44.2 \\
\hline & & & 5.8 & 3.1 & 5.2 & 1.1 & 13.3 \\
\hline \multirow[t]{2}{*}{1991} & 43.5 & 24.7 & 61.3 & 32.0 & 53.3 & 28.6 & 45.4 \\
\hline & & & 9.1 & 3.5 & 5.4 & 1.3 & 12.5 \\
\hline \multirow[t]{2}{*}{1992} & 43.5 & 24.7 & 61.3 & 32.0 & 53.0 & 28.5 & 45.3 \\
\hline & & & 9.1 & 3.5 & 4.7 & 1.2 & 14.1 \\
\hline \multirow[t]{2}{*}{1993} & 43.5 & 24.7 & 61.3 & 32.0 & 52.2 & 28.4 & 41.3 \\
\hline & & & 8.9 & 3.5 & 2.7 & 0.5 & 16.1 \\
\hline \multirow[t]{2}{*}{1994} & 43.5 & 24.7 & 61.0 & 32.1 & 52.9 & 28.5 & 40.3 \\
\hline & & & 8.5 & 3.5 & 3.4 & 0.5 & 14.2 \\
\hline
\end{tabular}

Notes: All rates are averaged across finance and assets. Weights used are: $28 \%$ buildings, $50 \%$ plant and machinery, 22\% inventories; $55 \%$ retained earnings, $10 \%$ new equity, $35 \%$ debt. Inflation and the real interest rate are held constant at $3.5 \%$ and $10 \%$ respectively. Columns 3 and 4 are weighted across countries by the proportion of inward FDI coming from each country (see Table A.1). Columns 5 and 6 are weighted across countries by the proportion of outward FDI going to each country (see Table A.2). The EATR in columns 2, 4 and 6 is for an investment earning a $40 \%$ real rate of return in the absence of tax. ATR is the average tax rate calculated using firm-level accounting data from Global Vantage. The standard deviations are shown in italics. They measure: in columns 3 and 4 , the variation 
across the nine source countries; in columns 5 and 6 , the variation across the nine residence countries; and in column 7, the variation across firms resident in Japan. See Appendix A for definition and interpretation of variables.

into Japan performed by countries in this study came from the US, while Canada, Germany and the UK each provided less than 10 per cent. Japan imposes withholding taxes on dividend and interest income of 10 per cent on US multinationals investing in Japan. Both the EMTR and the EATR on inward investment increase from 1979 to 1994 . The weighted effective marginal tax rate has hovered in the low fifties but increases significantly after 1990 . The average tax rate also increases after 1990, but less dramatically.

The fifth and sixth columns of Table I.4 show the effective tax rates for Japanese companies investing abroad. The geographical pattern seen for outward FDI is quite similar to that for inward FDI, with the US receiving almost 80 per cent, while the UK was the only other notable recipient of Japanese investment, at 14 per cent. The US imposes equivalent withholding taxes on interest and dividend income paid to Japan, at 10 per cent. Japan operates a world-wide credit system for foreign source income.

The EMTR increases dramatically in 1987 due to the impact of the US tax reform on the tax treatment of FDI flows from Japan to the US. It then declines again, but ends at a higher level than at the beginning of the period. The EATR, on the other hand, appears to be very stable. The effective marginal rate is lower for Japanese multinationals investing abroad than for other countries investing in Japan, apart from a four-year period in the late 1980s. The effective average tax rate facing Japanese companies investing abroad is slightly higher than that facing foreign multinationals investing in Japan at the start of the period, a situation which is reversed from 1990 onward. 
Taxing profits in a changing world

The final column of Table I.4 shows the average tax rate calculated using data from company accounts, where the tax rate for each firm is defined as the ratio of provision for tax to net pre-tax income and the median of those tax rates is presented here. The ATR falls from almost 50 per cent to close to 40 per cent between 1985 and 1994.

The standard deviation of the EMTR on inward investment has risen slightly, while that on the EATR has fallen slightly. Neither of these provide much evidence for a change in the degree of capital import neutrality. The standard deviation on the outward EMTR rises until the middle of the period and then falls again, ending at a lower level than it started at. The standard deviation on the EATR declines slightly. Thus there is some, albeit not very strong, indication of an increase in the degree of capital export neutrality on investment from Japan.

Figures I.1 and I.2 show the total amounts of foreign direct investment, both into and out of Japan, measured in millions of 1985 US dollars. For ease of presentation,

\section{FIGURE 1.1}

FDI into Japan

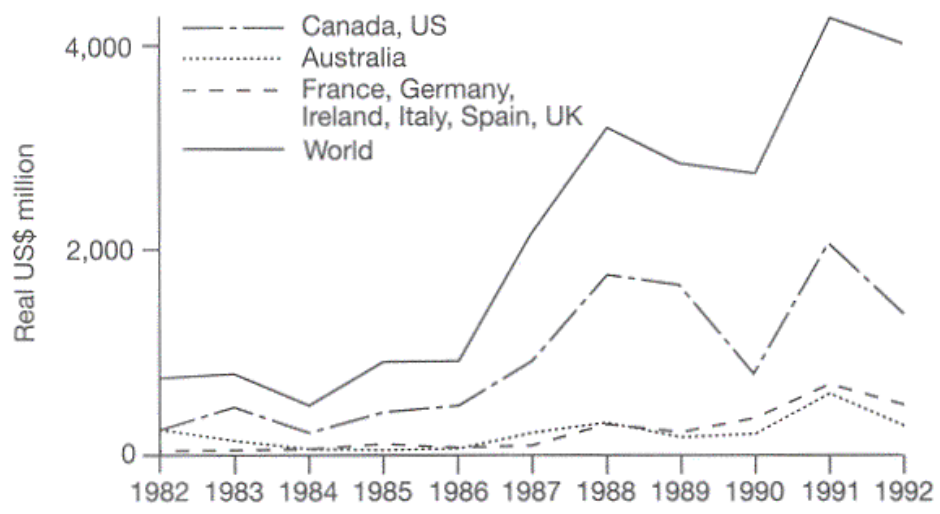

Sources: OECD International Direct Investment Statistics 1982-1993 database: exchange rate and US GDP deflator from OECD Economic Outlook. 
the sources and destinations of the FDI have been broken down by geographic region of the countries covered in the study: Europe, North America and a separate group for Australia. A total for the world is also given (this includes all countries, not just those covered in this study). The North American countries dominate the investment into Japan, although they rarely account for more than half of total inward FDI. By contrast, Japanese investment to the rest of the world goes to countries almost entirely outside the sample, bar some European countries.

FIGURE 1.2

FDI from Japan

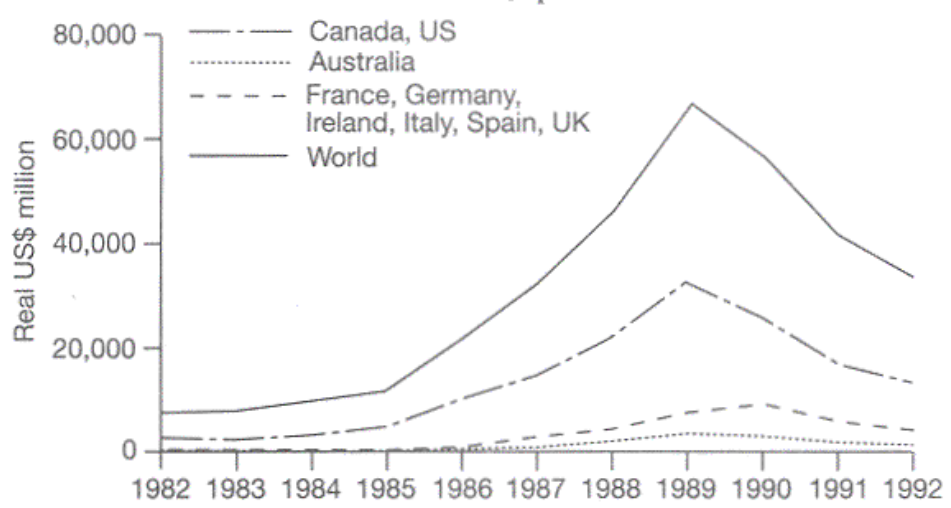

Sources: OECD International Direct Investment Statistics 1982-1993 database; exchange rate and US GDP deflator from OECD Economic Outlook. 


\section{APPENDIX J \\ Spain}

Along with Italy, Spain is one of the few countries to have raised its statutory rate of corporate income tax slightly, from 33 to 35 per cent in 1984. Depreciation allowances on buildings have increased, while those on plant and machinery have fallen, after a brief increase in the mid-1980s. The overall tax wedge has stayed very stable in the 16 years our study covers, ranging from 1.8 to 2.3, as shown in the final column of Table J.2. Corporation tax receipts have hovered at 1 to 3 per cent of GDP, and around 5 to 8 per cent of total tax receipts.

TABLE J.1

Spanish tax rates and NPV of allowances

\begin{tabular}{rrrrrrr}
\hline & $\begin{array}{r}\text { Headline } \\
\text { rate }\end{array}$ & $\begin{array}{r}\text { Statutory } \\
\text { rate }\end{array}$ & $\begin{array}{r}\text { NPV of } \\
\text { allowances } \\
\text { (buildings) }\end{array}$ & $\begin{array}{r}\text { NPV of } \\
\text { allowances } \\
\text { (plant and } \\
\text { machinery) }\end{array}$ & $\begin{array}{r}\text { CT } \\
\text { as a of } \\
\text { GDP }\end{array}$ & $\begin{array}{r}\text { CT as } a \\
\% \text { of } \\
\text { total } \\
\text { tax }\end{array}$ \\
\hline 1979 & 33.0 & $33.0(33.0)$ & 0.46 & 0.73 & 1.2 & 4.9 \\
1980 & 33.0 & $33.0(33.0)$ & 0.46 & 0.73 & 1.2 & 5.1 \\
1981 & 33.0 & $33.0(33.0)$ & 0.46 & 0.73 & 1.2 & 4.6 \\
1982 & 33.0 & $33.0(33.0)$ & 0.46 & 0.73 & 1.2 & 4.7 \\
1983 & 33.0 & $33.0(33.0)$ & 0.46 & 0.73 & 1.4 & 4.9 \\
1984 & 35.0 & $35.0(35.0)$ & 0.46 & 0.73 & 1.5 & 5.0 \\
1985 & 35.0 & $35.0(35.0)$ & 0.49 & 0.76 & 1.5 & 5.2 \\
1986 & 35.0 & $35.0(35.0)$ & 0.49 & 0.76 & 1.7 & 5.5 \\
1987 & 35.0 & $35.0(35.0)$ & 0.49 & 0.76 & 2.2 & 6.7 \\
1988 & 35.0 & $35.0(35.0)$ & 0.49 & 0.76 & 2.1 & 6.5 \\
1989 & 35.0 & $35.0(35.0)$ & 0.44 & 0.71 & 3.0 & 8.6 \\
1990 & 35.0 & $35.0(35.0)$ & 0.45 & 0.72 & 3.0 & 8.8 \\
1991 & 35.0 & $36.5(36.5)$ & 0.45 & 0.72 & 2.7 & 7.7 \\
1992 & 35.0 & $35.0(35.0)$ & 0.45 & 0.72 & 2.3 & 6.4 \\
1993 & 35.0 & $35.0(35.0)$ & 0.54 & 0.70 & 2.0 & 5.7 \\
1994 & 35.0 & $35.0(35.0)$ & 0.54 & 0.70 & 1.7 & 4.8 \\
\hline
\end{tabular}

${ }^{a}$ The statutory rate shows, first, the rate on retained earnings and then, in parentheses, the rate on distributed profits. It includes a surcharge in 1991. 
TABLE J.2

Spanish domestic effective marginal tax wedge

\begin{tabular}{l|rrr|rrr|r}
\hline & Buildings & $\begin{array}{r}\text { Plant and } \\
\text { machinery }\end{array}$ & Inventory & $\begin{array}{r}\text { Retained } \\
\text { earnings }\end{array}$ & $\begin{array}{r}\text { New } \\
\text { equity }\end{array}$ & Debt & Average \\
& 1 & 2 & 3 & 4 & 5 & 6 & 7 \\
\hline 1979 & 1.5 & 1.0 & 4.3 & 3.9 & 3.9 & -2.0 & 1.8 \\
1980 & 1.5 & 1.0 & 4.3 & 3.9 & 3.9 & -2.0 & 1.8 \\
1981 & 1.5 & 1.0 & 4.3 & 3.9 & 3.9 & -2.0 & 1.8 \\
1982 & 1.5 & 1.0 & 4.3 & 3.9 & 3.9 & -2.0 & 1.8 \\
1983 & 1.5 & 1.0 & 4.3 & 3.9 & 3.9 & -2.0 & 1.8 \\
1984 & 1.7 & 1.1 & 4.7 & 4.3 & 4.3 & -2.2 & 2.0 \\
1985 & 1.5 & 0.7 & 4.7 & 4.1 & 4.1 & -2.4 & 1.8 \\
1986 & 1.5 & 0.7 & 4.7 & 4.1 & 4.1 & -2.4 & 1.8 \\
1987 & 1.5 & 0.7 & 4.7 & 4.1 & 4.1 & -2.4 & 1.8 \\
1988 & 1.5 & 0.7 & 4.7 & 4.1 & 4.1 & -2.4 & 1.8 \\
1989 & 1.8 & 1.3 & 4.7 & 4.5 & 4.5 & -2.1 & 2.2 \\
1990 & 1.7 & 1.2 & 4.7 & 4.4 & 4.4 & -2.1 & 2.1 \\
1991 & 1.9 & 1.3 & 5.0 & 4.7 & 4.7 & -2.2 & 2.3 \\
1992 & 1.7 & 1.2 & 4.7 & 4.4 & 4.4 & -2.1 & 2.1 \\
1993 & 1.2 & 1.4 & 4.7 & 4.3 & 4.3 & -2.2 & 2.0 \\
1994 & 1.2 & 1.4 & 4.7 & 4.3 & 4.3 & -2.2 & 2.0 \\
\hline
\end{tabular}

Notes: Columns 1-3 are weighted averages across types of finance; columns 4-6 are weighted averages across assets; column 7 is a weighted average across both finance and assets. Weights used are: $28 \%$ buildings, $50 \%$ plant and machinery, $22 \%$ inventories; $55 \%$ retained earnings, $10 \%$ new equity, $35 \%$ debt. Inflation and the real interest rate are held constant at $3.5 \%$ and $10 \%$ respectively. See Appendix A for definition and interpretation of variables.

Table J.2 shows the figures for the effective tax wedge on a range of different investments and different forms of finance. Given the stability of the average tax wedge shown in the last column, it is not surprising that none of the individual tax wedges fluctuates dramatically. As expected from the changes in allowances, the tax wedge on buildings has fallen slightly and that on plant and machinery has increased. The wedge on inventories increased slightly as a result of the slight hike in the statutory tax rate. Even though Spain gives a tax credit on distributed profits, there is no difference in the tax wedge between financing the investment through retained earnings and financing it through new equity since it is assumed that the marginal investor is a tax-exempt shareholder. The tax advantage 


\section{Taxing profits in a changing world}

of financing through debt increases a little over time due to the slight increase in the statutory tax rate.

As with the wedge in the final column of Table J.2, the domestic effective marginal tax rate in the first column of Table J.3 has slightly increased over the period. Column 2 shows the effective average tax rate for a domestic investment earning a real rate of return of 40 per cent in the absence of tax. The effective average tax rate has also increased, but only by 1 percentage point. The remarkable feature is that the Spanish corporate tax system has remained so stable over the period.

The third column of the table gives the effective marginal tax rate for a foreign company investing in Spain, weighting the individual EMTRs by flows of foreign direct investment. Just over one-third of inward investment to Spain made by countries in this study between 1982 and 1992 came from France, one-fifth from the UK, 17 per cent from Germany and 14 per cent from the US. Spain imposes a withholding tax on interest income of 10 per cent on these countries (12 per cent for the UK) ${ }^{46}$ Dividend income also faces a withholding tax of 10 per cent. The weighted effective marginal tax rate fell in 1985 and in 1990, while the average effective tax rate has stayed lower and more stable.

Columns 5 and 6 of Table J.3 show the effective tax rates for Spanish companies investing abroad. The pattern seen for outward FDI is quite similar to that for inward FDI, although the UK is the major recipient of Spanish investment, receiving almost 29 per cent. The US receives one-quarter, France one-fifth and Italy 17

\footnotetext{
${ }^{46}$ The rate for the US has been higher historically and was as high as $20 \%$ from 1987 to 1989 .
} 
Spain

TABLE J.3

Spanish effective tax rates

\begin{tabular}{|c|c|c|c|c|c|c|c|}
\hline & \multicolumn{2}{|c|}{ Domestic } & \multicolumn{2}{|c|}{ Source } & \multicolumn{3}{|c|}{ Residence } \\
\hline & EMTR & EATR & EMTR & EATR & EMTR & EATR & $A T R$ \\
\hline & & & s.d. & s.d. & s.d. & s.d. & s.d. \\
\hline & 1 & 2 & 3 & 4 & 5 & 6 & 7 \\
\hline \multirow[t]{2}{*}{1979} & 18.4 & 18.6 & 51.4 & 25.3 & 41.5 & 32.0 & \\
\hline & & & 16.7 & 4.0 & 21.7 & 4.2 & \\
\hline \multirow[t]{2}{*}{1980} & 18.4 & 18.6 & 51.4 & 25.3 & 40.0 & 31.8 & \\
\hline & & & 16.7 & 4.0 & 20.1 & 4.0 & \\
\hline \multirow[t]{2}{*}{1981} & 18.4 & 18.6 & 51.1 & 25.3 & 37.4 & 31.3 & \\
\hline & & & 14.4 & 3.9 & 21.5 & 4.5 & \\
\hline \multirow[t]{2}{*}{1982} & 18.4 & 18.6 & 51.2 & 25.3 & 38.0 & 31.6 & \\
\hline & & & 14.3 & 3.9 & 21.1 & 4.1 & \\
\hline \multirow[t]{2}{*}{1983} & 18.4 & 18.6 & 49.6 & 25.1 & 34.6 & 30.5 & \\
\hline & & & 11.8 & 3.6 & 22.5 & 5.3 & \\
\hline \multirow[t]{2}{*}{1984} & 20.3 & 19.7 & 48.1 & 25.5 & 37.8 & 30.6 & \\
\hline & & & 9.3 & 2.6 & 19.4 & 4.9 & \\
\hline \multirow[t]{2}{*}{1985} & 18.1 & 19.4 & 43.8 & 24.8 & 38.9 & 30.0 & 40.3 \\
\hline & & & 10.6 & 2.5 & 17.0 & 5.3 & 16.0 \\
\hline \multirow[t]{2}{*}{1986} & 18.1 & 19.4 & 43.1 & 25.1 & 42.1 & 29.4 & 34.2 \\
\hline & & & 13.3 & 2.7 & 16.2 & 5.8 & 23.8 \\
\hline \multirow[t]{2}{*}{1987} & 18.1 & 19.4 & 42.6 & 25.0 & 40.5 & 28.1 & 24.4 \\
\hline & & & 12.9 & 2.7 & 15.4 & 4.5 & 18.6 \\
\hline \multirow[t]{2}{*}{1988} & 18.1 & 19.4 & 42.2 & 25.0 & 41.3 & 27.9 & 34.8 \\
\hline & & & 13.2 & 2.7 & 12.9 & 4.1 & 19.1 \\
\hline \multirow[t]{2}{*}{1989} & 21.8 & 19.9 & 45.4 & 25.6 & 41.4 & 27.8 & 29.6 \\
\hline & & & 13.0 & 2.5 & 12.9 & 4.0 & 22.4 \\
\hline \multirow[t]{2}{*}{1990} & 21.1 & 19.8 & 40.9 & 25.2 & 41.6 & 27.5 & 35.7 \\
\hline & & & 10.2 & 1.8 & 12.1 & 3.8 & 16.1 \\
\hline \multirow[t]{2}{*}{1991} & 22.6 & 20.7 & 42.7 & 26.1 & 36.9 & 26.1 & 26.2 \\
\hline & & & 11.4 & 1.8 & 5.4 & 2.8 & 24.3 \\
\hline \multirow[t]{2}{*}{1992} & 21.1 & 19.8 & 41.6 & 25.1 & 34.1 & 25.4 & 28.5 \\
\hline & & & 12.5 & 2.2 & 5.3 & 2.9 & 17.1 \\
\hline \multirow[t]{2}{*}{1993} & 20.4 & 19.7 & 44.6 & 25.4 & 32.1 & 25.1 & 25.7 \\
\hline & & & 23.2 & 3.1 & 6.5 & 2.9 & 16.4 \\
\hline \multirow[t]{2}{*}{1994} & 20.4 & 19.7 & 44.6 & 25.5 & 33.5 & 25.2 & 23.4 \\
\hline & & & 26.7 & 3.2 & 5.5 & 2.6 & 23.7 \\
\hline
\end{tabular}

Notes: All rates are averaged across finance and assets. Weights used are: $28 \%$ buildings, $50 \%$ plant and machinery, $22 \%$ inventories; $55 \%$ retained earnings, $10 \%$ new equity, $35 \%$ debt. Inflation and the real interest rate are held constant at $3.5 \%$ and $10 \%$ respectively. Columns 3 and 4 are weighted across countries by the proportion of inward FDI coming from each country (see Table A.1). Columns 5 and 6 are weighted across countries by the proportion of outward FDI going to each country (see Table A.2). The EATR in columns 2, 4 and 6 is for an investment earning a $40 \%$ real rate of return in the absence of tax. ATR is the average tax rate calculated using firm-level accounting data from Global Vantage. The standard deviations are shown in italics. They measure: in columns 3 and 4 , the variation across the nine source countries; in columns 5 and 6 , the variation across the nine residence countries; and in column 7, the variation across firms resident in Spain. See Appendix A for definition and interpretation of variables. 


\section{Taxing profits in a changing world}

per cent. Both the US and the UK impose withholding taxes on interest income paid to Spain, at 10 and 12 per cent respectively. The UK does not impose a withholding tax on dividend payments (but does not grant the imputation credit to Spanish companies), and the US imposes a 10 per cent rate. ${ }^{47}$ Spain operates a credit system for foreign source income.

The effective marginal rate is lower for Spanish multinationals investing abroad than for other countries investing in Spain, and the rate decreases over the period (increasing slightly in the late 1980s). The overall picture presented by the effective average tax rate is different. The EATR facing Spanish companies investing abroad is higher than that facing foreign multinationals investing in Spain at the start of the period, but the two rates converge.

The standard deviation for the source country EMTR increases in the last two years, while that for the EATR only increases slightly. Thus there is little evidence of an increase in the degree of capital import neutrality. However, the standard deviations for both the residence EMTR and the residence EATR decline, indicating some increase in the degree of capital export neutrality.

The final column of Table J.3 shows the average tax rate calculated using data from company accounts, where the tax rate for each firm is defined as the ratio of provision for tax to net pre-tax income and the median of those tax rates is presented here. The ATR is quite volatile but is based on a very small sample (see Table A.6). It exhibits a downward trend, falling from 40 to 23 per cent over the period for which data are available. It is more volatile than the EATR for Spanish companies

\footnotetext{
${ }^{47}$ The US had rates of $30 \%$ withholding on dividend and interest income up to and including 1990.
} 
investing abroad, and the variation between different companies is high.

Figures J.1 and J.2 show the total amounts of foreign direct investment, both into and out of Spain, measured in millions of 1985 US dollars. For ease of presentation, the sources and destinations of the FDI have been broken down by geographic region of the countries covered in the study: Europe excluding Spain, North America and a separate group for Australia and Japan. A total for the world is also given (this includes all countries, not just those covered in this study). The levels of FDI into and out of Spain increase steadily up to 1991, and of the countries we consider, the European group are the largest investors. However, most of the flows of investment into and out of Spain are accounted for by countries not covered by this study.

\section{FIGURE J.I}

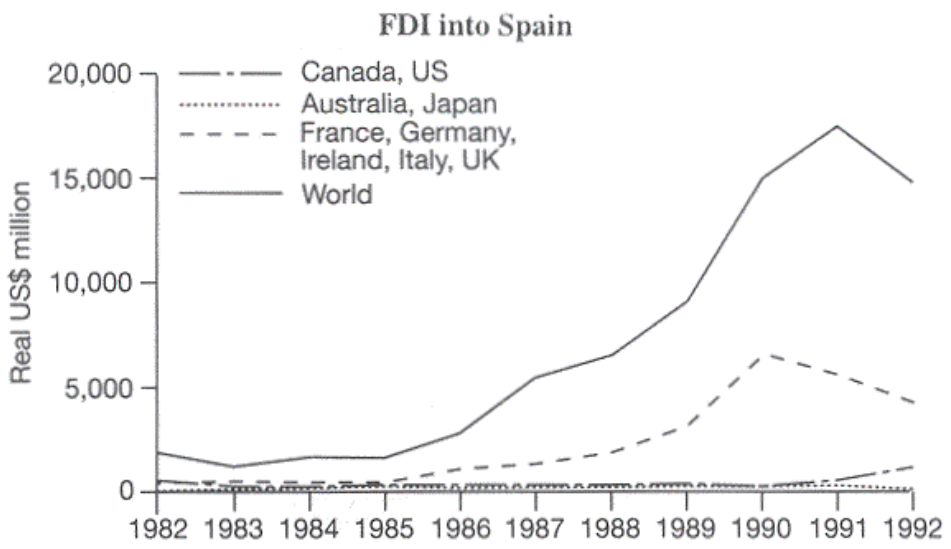

Sources: OECD International Direct Investment Statistics 1982-1993 database; exchange rate and US GDP deflator from OECD Economic Outlook. 
FIGURE J.2

\section{FDI from Spain}

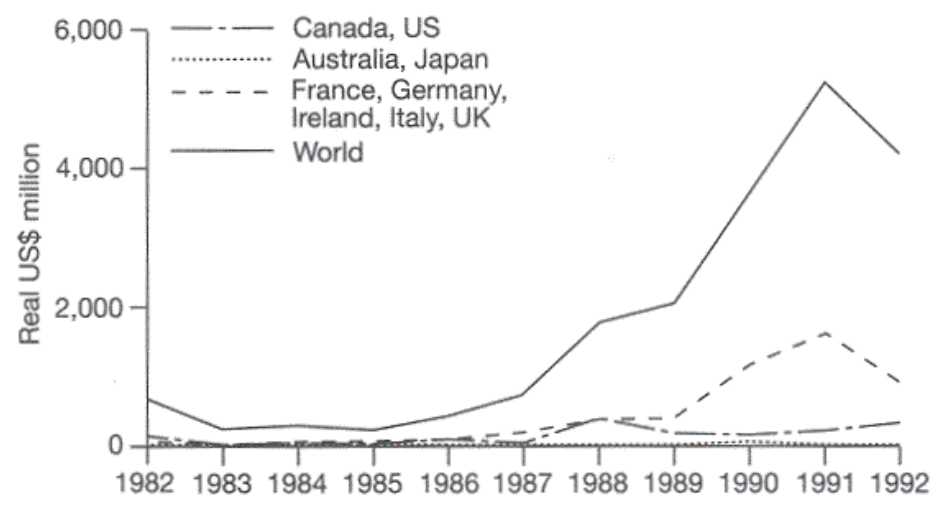

Sources: OECD International Direct Investment Statistics 1982-1993 database; exchange rate and US GDP deflator from OECD Economic: Outlook. 


\section{APPENDIX K}

\section{UK}

The UK experienced one major reform to the corporate tax system during the period, in 1984. This combined a substantial reduction in the rate of corporate tax with reductions in the allowances available on plant and machinery and buildings, in a move away from an expenditure-based tax. As a result, the overall tax wedge rose from -0.5 in 1979 (implying a subsidy to corporate investment) to 1.7 in 1994, as shown in the final column

TABLE K.1

UK tax rates and NPV of allowances

\begin{tabular}{rrrrrrr}
\hline & $\begin{array}{r}\text { Headline } \\
\text { rate }\end{array}$ & $\begin{array}{r}\text { Statutory } \\
\text { rate }^{a}\end{array}$ & $\begin{array}{r}\text { NPVof } \\
\text { allowances } \\
\text { (buildings) }\end{array}$ & $\begin{array}{r}\text { NPVof } \\
\text { allowances } \\
\text { plant and } \\
\text { machinery) }\end{array}$ & $\begin{array}{r}\text { CT a } \\
\text { as of } \\
\text { GDP }\end{array}$ & $\begin{array}{r}\text { CT as a } \\
\text { o of } \\
\text { total } \\
\text { tax }\end{array}$ \\
\hline 1979 & 52.0 & $52.0(52.0)$ & 0.73 & 1.00 & 2.5 & 7.7 \\
1980 & 52.0 & $52.0(52.0)$ & 0.73 & 1.00 & 3.0 & 8.3 \\
1981 & 52.0 & $52.0(52.0)$ & 0.91 & 1.00 & 3.5 & 9.5 \\
1982 & 52.0 & $52.0(52.0)$ & 0.91 & 1.00 & 3.9 & 9.9 \\
1983 & 50.0 & $50.0(50.0)$ & 0.91 & 1.00 & 4.1 & 10.9 \\
1984 & 45.0 & $45.0(45.0)$ & 0.73 & 0.93 & 4.5 & 11.8 \\
1985 & 40.0 & $40.0(40.0)$ & 0.51 & 0.87 & 4.8 & 12.6 \\
1986 & 35.0 & $35.0(35.0)$ & 0.32 & 0.73 & 4.0 & 10.5 \\
1987 & 35.0 & $35.0(35.0)$ & 0.32 & 0.73 & 3.9 & 10.5 \\
1988 & 35.0 & $35.0(35.0)$ & 0.32 & 0.73 & 4.0 & 10.7 \\
1989 & 35.0 & $35.0(35.0)$ & 0.32 & 0.73 & 4.4 & 12.1 \\
1990 & 34.0 & $34.0(34.0)$ & 0.32 & 0.73 & 3.9 & 10.8 \\
1991 & 33.0 & $33.0(33.0)$ & 0.32 & 0.73 & 3.3 & 9.2 \\
1992 & 33.0 & $33.0(33.0)$ & 0.32 & 0.73 & 2.6 & 7.4 \\
1993 & 33.0 & $33.0(33.0)$ & 0.47 & 0.79 & 2.4 & 7.2 \\
1994 & 33.0 & $33.0(33.0)$ & 0.32 & 0.73 & 2.7 & 8.0 \\
\hline
\end{tabular}

${ }^{\mathrm{a}}$ The statutory rate shows, first, the rate on retained earnings and then, in parentheses, the rate on distributed profits.

Note: No local corporate taxes or surcharges are levied. 
Taxing profits in a changing world

TABLE K.2

UK domestic effective marginal tax wedge

\begin{tabular}{l|rrr|rrr|r}
\hline & Buildings & $\begin{array}{r}\text { Plant and } \\
\text { machinery }\end{array}$ & Inventory & $\begin{array}{r}\text { Retained } \\
\text { earnings }\end{array}$ & $\begin{array}{r}\text { New } \\
\text { equity }\end{array}$ & Debt & Average \\
& 1 & 2 & 3 & 4 & 5 & 6 & 7 \\
\hline 1979 & 0.0 & -2.8 & 8.6 & 4.3 & -1.1 & -5.1 & -0.5 \\
1980 & 0.0 & -2.8 & 8.6 & 4.3 & -1.1 & -5.1 & -0.5 \\
1981 & -1.9 & -2.8 & 8.6 & 3.6 & -1.6 & -5.3 & -0.1 \\
1982 & -1.9 & -2.8 & 8.6 & 3.6 & -1.6 & -5.3 & -0.1 \\
1983 & -1.9 & -2.7 & 7.9 & 3.3 & -1.8 & -5.1 & -0.2 \\
1984 & -0.3 & -1.6 & 6.5 & 4.9 & -1.5 & -4.1 & -1.5 \\
1985 & 1.1 & -0.7 & 5.1 & 4.2 & -1.3 & -3.1 & 1.1 \\
1986 & 2.0 & 0.6 & 4.1 & 4.6 & -1.8 & -1.9 & 1.8 \\
1987 & 2.0 & 0.6 & 4.1 & 4.6 & -0.5 & -1.9 & 1.8 \\
1988 & 2.1 & 0.7 & 4.2 & 4.6 & -0.1 & -1.9 & 1.8 \\
1989 & 2.1 & 0.7 & 4.2 & 4.6 & -0.1 & -1.9 & 1.8 \\
1990 & 2.0 & 0.6 & 4.0 & 4.4 & -0.2 & -1.9 & 1.7 \\
1991 & 1.9 & 0.6 & 3.8 & 4.2 & -0.4 & -1.8 & 1.6 \\
1992 & 1.9 & 0.6 & 3.8 & 4.2 & -0.4 & -1.8 & 1.6 \\
1993 & 1.1 & 0.2 & 3.9 & 3.6 & 0.1 & -2.2 & 1.2 \\
1994 & 2.0 & 0.6 & 3.9 & 4.2 & 0.5 & -1.8 & 1.7 \\
\hline
\end{tabular}

Notes: Columns 1-3 are weighted averages across types of finance; columns 4-6 are weighted averages across assets; column 7 is a weighted average across both finance and assets. Weights used are: $28 \%$ buildings, $50 \%$ plant and machinery, $22 \%$ inventories; $55 \%$ retained earnings, $10 \%$ new equity, 35\% debt. Inflation and the real interest rate are held constant at 3.5\% and 10\% respectively. See Appendix A for definition and interpretation of variables.

of Table K.2 ${ }^{48}$ Corporation tax receipts have fluctuated from 2.5 to 4.8 per cent of GDP, and around 7 to 12 per cent of total tax receipts, showing the sensitivity of receipts to the business cycle.

Table K.2 shows the figures for the effective tax wedge on a range of different investments and different forms of finance. The tax wedges both on buildings and on plant and machinery have increased, but the tax

\footnotetext{
${ }^{48}$ Note that if account is taken of the fact that the changes to the tax system were pre-announced, through a consultative period, the tax wedge would show a different pattern in 1984 and 1985, when it would fall dramatically. This is because the announcement that future allowances would be lower and would be offset against a lower tax rate reduces the effective tax rate for current investment.
} 
wedge on inventories has decreased, largely due to the fall in the statutory rate. Prior to 1984 , generous firstyear allowances (in some cases 100 per cent allowances) were granted both to buildings and to plant and machinery; these were phased out in the period 1984-86. The statutory tax rate was lowered by 15 percentage points between 1983 and 1986.

The figures shown in column 4 of Table K.2 are the tax wedge on an investment financed by retained earnings averaged across assets. The tax wedge on investment financed by retained earnings has stayed relatively stable over the period, apart from a small reduction in the early 1980s caused by a more generous regime for industrial buildings. Investment financed by new equity is effectively given a small subsidy until 1993, as a result of the refundability of the tax credit given under the imputation system. As in other countries, the favourable treatment of debt has declined with the fall in the statutory rate.

As with the wedge in the final column of Table K.2, the domestic effective marginal tax rate in the first column of Table K.3 has substantially increased over the period. Column 2 shows the effective average tax rate for a domestic investment earning a real rate of return of 40 per cent in the absence of tax. The effective average tax rate has declined, however. This is due to the fact that the impact of the reduction in depreciation allowances is less important for highly profitable firms. The EATR tends toward the statutory rate as the rate of return on the investment project increases.

The third column of Table K.3 gives the effective marginal tax rate for a foreign company investing in the

${ }^{49}$ Following changes to the tax treatment of dividends in the 1997 Budget, the tax credit is no longer refundable for pension funds and companies. 
Taxing profits in a changing world

TABLE K.3

UK effective tax rates

\begin{tabular}{|c|c|c|c|c|c|c|c|}
\hline & \multicolumn{2}{|c|}{ Domestic } & \multicolumn{2}{|c|}{ Source } & \multicolumn{3}{|c|}{ Residence } \\
\hline & EMTR & EATR & EMTR & EATR & EMTR & EATR & $A T R$ \\
\hline & & & s.d. & s.d. & s.d. & s.d. & s.d. \\
\hline & 1 & 2 & 3 & 4 & 5 & 6 & 7 \\
\hline \multirow[t]{2}{*}{1979} & 4.7 & 24.1 & 17.5 & 29.0 & 43.1 & 29.1 & \\
\hline & & & 2.4 & 1.1 & 15.8 & 2.9 & \\
\hline \multirow[t]{2}{*}{1980} & 4.7 & 24.1 & 17.5 & 29.0 & 40.0 & 28.8 & \\
\hline & & & 2.4 & 1.1 & 17.8 & 3.1 & \\
\hline \multirow[t]{2}{*}{1981} & -0.6 & 23.4 & 11.5 & 28.2 & 42.1 & 28.7 & \\
\hline & & & 2.3 & 1.1 & 20.2 & 3.1 & \\
\hline \multirow[t]{2}{*}{1982} & -0.6 & 23.4 & 11.5 & 28.2 & 40.6 & 28.5 & \\
\hline & & & 2.3 & 1.1 & 17.6 & 2.7 & \\
\hline \multirow[t]{2}{*}{1983} & -1.6 & 22.4 & 12.0 & 27.4 & 38.7 & 28.5 & \\
\hline & & & 2.8 & 1.4 & 15.6 & 2.7 & \\
\hline \multirow[t]{2}{*}{1984} & 5.4 & 20.9 & 24.2 & 26.8 & 34.3 & 28.3 & \\
\hline & & & 5.6 & 2.5 & 12.1 & 2.8 & \\
\hline \multirow[t]{2}{*}{1985} & 11.0 & 19.3 & 35.1 & 26.1 & 31.0 & 27.9 & 27.8 \\
\hline & & & 9.3 & 3.7 & 11.1 & 3.2 & 14.5 \\
\hline \multirow[t]{2}{*}{1986} & 17.6 & 18.0 & 48.3 & 25.9 & 29.8 & 27.6 & 33.2 \\
\hline & & & 16.3 & 5.1 & 12.9 & 3.6 & 14.2 \\
\hline \multirow[t]{2}{*}{1987} & 18.0 & 18.2 & 39.0 & 23.8 & 33.0 & 25.1 & 35.1 \\
\hline & & & 15.7 & 4.1 & 11.4 & 4.4 & 15.5 \\
\hline \multirow[t]{2}{*}{1988} & 18.4 & 18.4 & 38.6 & 24.0 & 32.0 & 24.5 & 32.3 \\
\hline & & & 15.9 & 3.9 & 6.6 & 2.8 & 14.5 \\
\hline \multirow[t]{2}{*}{1989} & 18.4 & 18.4 & 37.9 & 24.0 & 32.9 & 24.5 & 31.1 \\
\hline & & & 14.2 & 3.7 & 7.9 & 2.8 & 12.9 \\
\hline \multirow[t]{2}{*}{1990} & 17.3 & 17.8 & 35.8 & 23.6 & 32.7 & 24.4 & 30.7 \\
\hline & & & 11.3 & 3.2 & 7.8 & 2.8 & 13.2 \\
\hline \multirow[t]{2}{*}{1991} & 16.4 & 17.2 & 35.7 & 23.2 & 33.3 & 24.5 & 31.3 \\
\hline & & & 12.6 & 3.5 & 9.7 & 3.0 & 15.1 \\
\hline \multirow[t]{2}{*}{1992} & 16.4 & 17.2 & 35.6 & 23.1 & 32.0 & 24.1 & 29.5 \\
\hline & & & 12.8 & 3.7 & 9.2 & 3.0 & 15.7 \\
\hline \multirow[t]{2}{*}{1993} & 12.4 & 16.9 & 30.9 & 22.6 & 31.9 & 24.2 & 28.7 \\
\hline & & & 14.2 & 3.7 & 6.0 & 2.0 & 14.0 \\
\hline \multirow[t]{2}{*}{1994} & 17.3 & 17.7 & 36.1 & 23.4 & 31.6 & 24.1 & 28.7 \\
\hline & & & 15.1 & 3.5 & 6.1 & 2.0 & 12.4 \\
\hline
\end{tabular}

Notes: All rates are averaged across finance and assets. Weights used are: $28 \%$ buildings, $50 \%$ plant and machinery, $22 \%$ inventories; $55 \%$ retained earnings, $10 \%$ new equity, $35 \%$ debt. Inflation and the real interest rate are held constant at $3.5 \%$ and $10 \%$ respectively. Columns 3 and 4 are weighted across countries by the proportion of inward FDI coming from each country (see Table A.1). Columns 5 and 6 are weighted across countries by the proportion of outward FDI going to each country (see Table A.2). The EATR in columns 2, 4 and 6 is for an investment earning a $40 \%$ real rate of return in the absence of tax. ATR is the average tax rate calculated using firm-level accounting data from Global Vantage. The standard deviations are shown in italics. They measure: in columns 3 and 4 , the variation across the nine source countries; in columns 5 and 6 , the variation across the nine residence countries; and in column 7, the variation across firms resident in the UK. See Appendix A for definition and interpretation of variables. 
UK. This is a weighted average of the EMTRs from each country, weighted by the proportion of foreign direct investment coming from that country. Almost half of inward investment to the UK performed by countries in this study between 1982 and 1992 came from the US, 15 per cent from France and one-tenth each from Japan and Australia. Germany is another significant investor in the UK. The UK imposes various rates of withholding tax on interest income on the countries in our sample, most commonly zero or 10 per cent in recent years. Withholding taxes on dividend income are also levied, but the countries covered here either face a zero rate or in fact receive an imputation credit of 50 per cent of the dividend tax payment made to the UK revenue (which is then added to dividend received and a withholding tax of 5 or 10 per cent is imposed). The weighted EMTR rises over the period, while the average tax rate falls. The standard deviations on both the source EMTR and the source EATR increase over the period, indicating that the degree of capital import neutrality in the UK has decreased.

Columns 5 and 6 show the effective tax rates for UK multinationals investing abroad. The pattern seen for inward FDI is similar to that for outward FDI. The US is the major recipient of investment from UK companies, accounting for over 60 per cent of outward FDI. Again, Australia and France receive smaller but significant flows. The US does not impose withholding taxes on dividends and interest on payments returning to the UK. The UK operates a credit system for foreign source income.

The effective marginal rate is higher for UK multinationals investing abroad than for other countries investing in the UK until 1985, but the rate decreases over the period. The EATR more closely follows the average tax rate facing foreign multinationals investing 


\section{Taxing profits in a changing world}

in the UK, both in the level and in the downward trend over time. The standard deviation of the residence EMTR falls, indicating an increase in the degree of capital export neutrality, although this is not confirmed by the standard deviation of the EATR.

The final column of Table K.3 shows the average tax rate calculated using data from company accounts, where the tax rate for each firm is defined as the ratio of provision for tax to net pre-tax income and the median of those tax rates is presented here. The ATR begins and ends the period at about 28 per cent, but rose up to 1987, falling back again thereafter.

FIGURE K.I

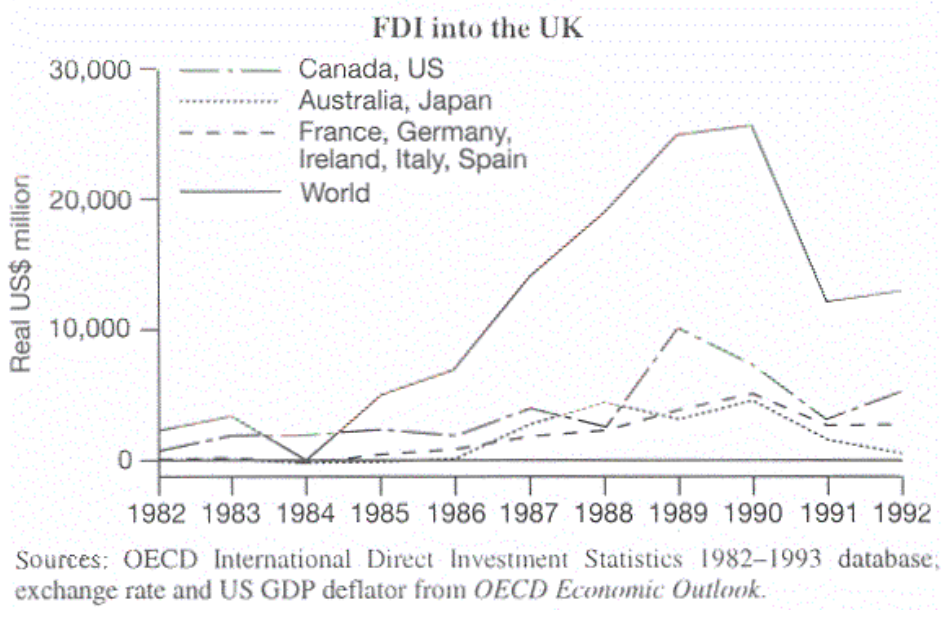

Figures K.1 and K.2 show the total amounts of foreign direct investment, both into and out of the UK, measured in millions of 1985 US dollars. For ease of presentation, the sources and destinations of the FDI have been broken down by geographic region of the countries covered in the study: Europe excluding the UK, North America and a separate group for Australia and Japan. A total for the world is also given (this includes all countries, not just those covered in this 
study). The level of investment into the UK rose up to 1990 but fell off in 1991. The level of UK investment abroad peaked in 1988 and was dominated by investment into the US during most of the period.

\section{FIGURE K.2}

FDI from the UK

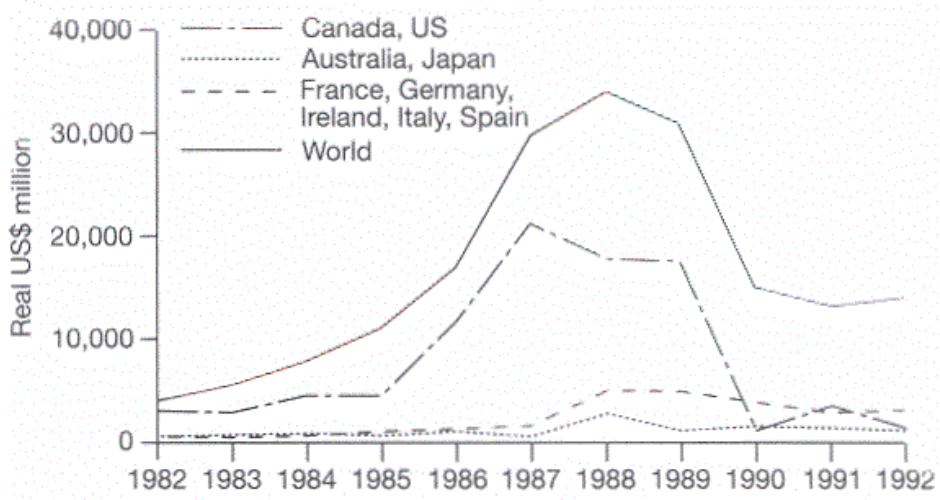

Sources: OECD International Direct Investment Statistics 1982-1993 database: exchange rate and US GDP deflator from OECD Economic Outlook. 


\section{APPENDIX L}

US

The US has had two major tax reforms during this period - the Economic Recovery Tax Act of 1981 and Economic Recovery Act of 1986. The 1981 Act introduced a new system of depreciation allowances, although this change did not affect the generosity of allowances on plant and machinery. The headline tax rate on corporate income was reduced from 46 per cent to 34 per cent as part of the wide-ranging tax reform in 1986. This reform also broadened the base by making depreciation allowances on both buildings and plant and

TABLE L. 1

US tax rates and NPV of allowances

\begin{tabular}{rrrrrrr}
\hline & $\begin{array}{r}\text { Headline } \\
\text { rate }\end{array}$ & $\begin{array}{r}\text { Statutory } \\
\text { rate }^{a}\end{array}$ & $\begin{array}{r}\text { NPVof } \\
\text { allowances } \\
\text { (buildings) }\end{array}$ & $\begin{array}{r}\text { NPV of } \\
\text { allowances } \\
\text { (plant and } \\
\text { machinery) }\end{array}$ & $\begin{array}{r}\text { CT } \\
\text { as a of } \\
\text { GDP }\end{array}$ & $\begin{array}{r}\text { CT as a } \\
\text { \% of } \\
\text { total } \\
\text { tax }\end{array}$ \\
\hline 1979 & 46.0 & $49.6(49.6)$ & 0.43 & 0.87 & 3.4 & 11.2 \\
1980 & 46.0 & $49.6(49.6)$ & 0.43 & 0.87 & 3.0 & 10.2 \\
1981 & 46.0 & $49.6(49.6)$ & 0.56 & 0.87 & 2.6 & 8.6 \\
1982 & 46.0 & $49.6(49.6)$ & 0.56 & 0.87 & 2.1 & 6.9 \\
1983 & 46.0 & $49.6(49.6)$ & 0.56 & 0.87 & 1.6 & 5.5 \\
1984 & 46.0 & $49.6(49.6)$ & 0.56 & 0.87 & 2.0 & 7.1 \\
1985 & 46.0 & $49.6(49.6)$ & 0.56 & 0.87 & 2.1 & 7.1 \\
1986 & 46.0 & $49.6(49.6)$ & 0.56 & 0.87 & 2.0 & 7.0 \\
1987 & 34.0 & $38.4(38.4)$ & 0.26 & 0.78 & 2.4 & 8.1 \\
1988 & 34.0 & $38.4(38.4)$ & 0.26 & 0.78 & 2.5 & 8.4 \\
1989 & 34.0 & $38.4(38.4)$ & 0.26 & 0.78 & 2.5 & 8.5 \\
1990 & 34.0 & $38.4(38.4)$ & 0.26 & 0.78 & 2.1 & 7.7 \\
1991 & 34.0 & $38.4(38.4)$ & 0.26 & 0.78 & 2.1 & 7.7 \\
1992 & 34.0 & $38.4(38.4)$ & 0.26 & 0.78 & 2.0 & 7.6 \\
1993 & 35.0 & $39.3(39.3)$ & 0.21 & 0.78 & 2.2 & 8.3 \\
1994 & 35.0 & $39.3(39.3)$ & 0.21 & 0.78 & 2.5 & 8.9 \\
\hline
\end{tabular}

${ }^{\text {a }}$ The statutory rate shows, first, the rate on retained earnings and then, in parentheses, the rate on distributed profits. It includes an average of state corporate income taxes of $6.6 \%$, which is deductible from federal taxes, for every year. 
TABLE L.2

US domestic effective marginal tax wedge

\begin{tabular}{l|rrr|rrr|r}
\hline & Buildings & $\begin{array}{r}\text { Plant and } \\
\text { machinery }\end{array}$ & Inventory & $\begin{array}{r}\text { Retained } \\
\text { earnings }\end{array}$ & $\begin{array}{r}\text { New } \\
\text { equity }\end{array}$ & Debt & Average \\
& 1 & 2 & 3 & 4 & 5 & 6 & 7 \\
\hline 1979 & 3.6 & -0.3 & 5.2 & 5.7 & 5.7 & -4.9 & 2.0 \\
1980 & 3.6 & -0.3 & 5.2 & 5.7 & 5.7 & -4.9 & 2.0 \\
1981 & 2.2 & -0.4 & 5.2 & 5.2 & 5.2 & -5.1 & 1.6 \\
1982 & 2.2 & -0.4 & 5.2 & 5.2 & 5.2 & -5.1 & 1.6 \\
1983 & 2.2 & -0.4 & 5.2 & 5.2 & 5.2 & -5.1 & 1.6 \\
1984 & 2.2 & -0.4 & 5.2 & 5.2 & 5.2 & -5.1 & 1.6 \\
1985 & 2.2 & -0.4 & 5.2 & 5.2 & 5.2 & -5.1 & 1.6 \\
1986 & 2.2 & -0.4 & 5.2 & 5.2 & 5.2 & -5.1 & 1.6 \\
1987 & 3.4 & 0.7 & 3.3 & 4.6 & 4.6 & -2.7 & 2.0 \\
1988 & 3.4 & 0.7 & 3.3 & 4.6 & 4.6 & -2.7 & 2.0 \\
1989 & 3.4 & 0.7 & 3.3 & 4.6 & 4.6 & -2.7 & 2.0 \\
1990 & 3.4 & 0.7 & 3.3 & 4.6 & 4.6 & -2.7 & 2.0 \\
1991 & 3.4 & 0.7 & 3.3 & 4.6 & 4.6 & -2.7 & 2.0 \\
1992 & 3.4 & 0.7 & 3.3 & 4.6 & 4.6 & -2.7 & 2.0 \\
1993 & 4.0 & 0.8 & 3.4 & 4.9 & 4.9 & -2.7 & 2.2 \\
1994 & 4.0 & 0.8 & 3.4 & 4.9 & 4.9 & -2.7 & 2.2 \\
\hline
\end{tabular}

Notes: Columns 1-3 are weighted averages across types of finance; columns 4-6 are weighted averages across assets; column 7 is a weighted average across both finance and assets. Weights used are: $28 \%$ buildings, $50 \%$ plant and machinery, $22 \%$ inventories; $55 \%$ retained earnings, $10 \%$ new equity, 35\% debt. Inflation and the real interest rate are held constant at 3.5\% and $10 \%$ respectively. See Appendix A for definition and interpretation of variables.

machinery less generous through the Modified Accelerated Cost Recovery System (MACRS). In addition, an investment tax credit of 10 per cent on investment in plant and machinery was abolished. These two effects led to an increase in the average tax wedge in 1987, as shown in the final column of Table L.2. Corporate tax receipts declined during the early $1980 \mathrm{~s}$ as a proportion of the US's GDP, but picked up again somewhat during the late 1980 s and early 1990s, although they have shown some cyclical fluctuations. The same is true for the proportion of total tax revenue raised from corporate tax.

Table L. 2 shows the effective marginal tax wedge for domestic investment, broken down by asset and by type 


\section{Taxing profits in a changing world}

of finance. The overall effective marginal tax wedge shown in the final column declined in 1981, due to the introduction of a more generous allowance on investment in buildings. It rose again in 1987, as a result of the rate-lowering, base-broadening reform. The wedge on inventories has declined due to the reduction in the statutory tax rate. The US operates a classical system so there is no integration of the personal and corporate income tax systems. Thus, for the tax-exempt shareholder considered here, the wedge on an investment financed by retained earnings is the same as that financed by new equity. These have both declined during the period due to the decrease in the statutory tax rate. The tax wedge on an investment financed by interest has increased due to the reduction in the statutory tax rate (thus making deductibility of interest payments worth less).

As with the tax wedge given in the final column of Table L.2, the domestic effective marginal tax rate in the first column of Table L.3 fell in the early 1980s, increasing after the changes introduced by the 1986 reforms. Column 2 shows the effective average tax rate for a domestic investment earning a real rate of return of 40 per cent in the absence of tax. The effective average tax rate has decreased slightly, reflecting the greater importance of the lower statutory tax rate for more profitable investments.

Columns 3 and 4 show the effective tax rates on investment into the US. These are averages across the other nine countries, weighted by the proportion of FDI coming from each country (see Table A.1). Between 1982 and 1992, almost 40 per cent of inward investment into the US (by countries in this study) came from the UK, one-third from Japan, with around 7-8 per cent coming from each of Canada, France and Germany. The 
TABLE L.3

US effective tax rates

\begin{tabular}{|c|c|c|c|c|c|c|c|}
\hline & \multicolumn{2}{|c|}{ Domestic } & \multicolumn{2}{|c|}{ Source } & \multicolumn{3}{|c|}{ Residence } \\
\hline & EMTR & EATR & EMTR & EATR & EMTR & EATR & $A T R$ \\
\hline & & & s.d. & s.d. & s.d. & s.d. & s.d. \\
\hline & 1 & 2 & 3 & 4 & 5 & 6 & 7 \\
\hline \multirow[t]{2}{*}{1979} & 20.1 & 21.8 & 41.5 & 28.6 & 40.2 & 30.5 & \\
\hline & & & 11.3 & 1.4 & 22.2 & 3.2 & \\
\hline \multirow[t]{2}{*}{1980} & 20.1 & 21.8 & 41.5 & 28.6 & 40.6 & 30.7 & \\
\hline & & & 11.3 & 1.4 & 22.2 & 3.2 & \\
\hline \multirow[t]{2}{*}{1981} & 15.8 & 21.2 & 36.7 & 28.0 & 40.3 & 30.1 & \\
\hline & & & 11.3 & 1.5 & 23.3 & 4.0 & \\
\hline \multirow[t]{2}{*}{1982} & 15.8 & 21.2 & 36.7 & 28.0 & 39.3 & 30.0 & \\
\hline & & & 11.3 & 1.5 & 21.8 & 3.8 & \\
\hline \multirow[t]{2}{*}{1983} & 15.8 & 21.2 & 36.4 & 28.1 & 39.2 & 29.9 & \\
\hline & & & 11.5 & 1.4 & 19.9 & 3.7 & \\
\hline \multirow[t]{2}{*}{1984} & 15.8 & 21.2 & 35.6 & 28.1 & 41.9 & 29.6 & \\
\hline & & & 12.1 & 1.4 & 13.5 & 3.5 & \\
\hline \multirow[t]{2}{*}{1985} & 15.8 & 21.2 & 34.4 & 28.0 & 44.9 & 29.7 & 38.0 \\
\hline & & & 12.5 & 1.3 & 8.0 & 3.3 & 13.0 \\
\hline \multirow[t]{2}{*}{1986} & 15.8 & 21.2 & 35.5 & 28.1 & 50.3 & 29.9 & 39.3 \\
\hline & & & 14.0 & 1.5 & 8.9 & 3.4 & 13.7 \\
\hline \multirow[t]{2}{*}{1987} & 20.5 & 18.9 & 48.8 & 25.9 & 39.4 & 27.9 & 36.2 \\
\hline & & & 21.3 & 4.0 & 12.8 & 5.2 & 14.7 \\
\hline \multirow[t]{2}{*}{1988} & 20.5 & 18.9 & 48.6 & 26.1 & 38.4 & 26.8 & 31.2 \\
\hline & & & 21.4 & 3.8 & 7.8 & 3.8 & 14.6 \\
\hline \multirow[t]{2}{*}{1989} & 20.5 & 18.9 & 46.7 & 25.9 & 39.0 & 26.7 & 32.7 \\
\hline & & & 19.3 & 3.4 & 8.1 & 3.7 & 14.5 \\
\hline \multirow[t]{2}{*}{1990} & 20.5 & 18.9 & 42.3 & 25.6 & 38.8 & 26.4 & 34.1 \\
\hline & & & 14.4 & 2.8 & 7.9 & 3.6 & 12.6 \\
\hline \multirow[t]{2}{*}{1991} & 20.5 & 18.9 & 43.5 & 25.7 & 40.6 & 26.5 & 32.2 \\
\hline & & & 16.2 & 3.1 & 11.0 & 4.0 & 14.2 \\
\hline \multirow[t]{2}{*}{1992} & 20.5 & 18.9 & 41.7 & 25.2 & 39.4 & 26.3 & 31.5 \\
\hline & & & 15.0 & 3.6 & 11.2 & 4.2 & 14.4 \\
\hline \multirow[t]{2}{*}{1993} & 22.4 & 19.5 & 43.6 & 26.0 & 36.7 & 25.6 & 33.4 \\
\hline & & & 14.7 & 3.3 & 10.5 & 3.8 & 14.8 \\
\hline \multirow[t]{2}{*}{1994} & 22.4 & 19.5 & 42.6 & 25.9 & 37.2 & 25.4 & 33.3 \\
\hline & & & 14.0 & 3.0 & 9.6 & 3.3 & 12.8 \\
\hline
\end{tabular}

Notes: All rates are averaged across finance and assets. Weights used are: $28 \%$ buildings, $50 \%$ plant and machinery, $22 \%$ inventories; $55 \%$ retained earnings, $10 \%$ new equity, $35 \%$ debt. Inflation and the real interest rate are held constant at $3.5 \%$ and $10 \%$ respectively. Columns 3 and 4 are weighted across countries by the proportion of inward FDI coming from each country (see Table A.1). Columns 5 and 6 are weighted across countries by the proportion of outward FDI going to each country (see Table A.2). The EATR in columns 2, 4 and 6 is for an investment earning a $40 \%$ real rate of return in the absence of tax. ATR is the average tax rate calculated using firm-level accounting data from Global Vantage. The standard deviations are shown in italics. They measure: in columns 3 and 4 , the variation across the nine source countries; in columns 5 and 6 , the variation across the nine residence countries; and in column 7, the variation across firms resident in the US. See Appendix A for definition and interpretation of variables. 


\section{Taxing profits in a changing world}

US imposes a withholding tax on interest income of 10 per cent on payments to Japan (but zero for the UK). Dividend income also faces a withholding tax of 10 per cent for payments to Japan, and 5 per cent for the UK. The resulting weighted EMTR has fluctuated, though remained within the range 34-49 per cent. It remains some 20 percentage points higher than the EMTR on a domestic investment. The EATR on inward investment is, on the other hand, similar in level and in its progress over time to the domestic EATR.

The fifth and sixth columns of Table L.3 show the effective tax rates for US companies investing abroad. The US_pperates a credit system for foreign source income. 50 The pattern seen for outward FDI is slightly different from that for inward FDI: while the UK is again important, receiving 30 per cent of the US FDI performed abroad, Canada and Germany (at 20 per cent and 12 per cent respectively) receive more US investment than Japan (at 5 per cent). Canada imposed a withholding tax on interest income paid to the US of 15 per cent (falling to 10 per cent in 1992), and prior to 1986 France levied one of 10 per cent. The UK did not withhold tax on interest income, and granted a partial tax credit on dividend income (see Appendix K). Dividend withholding taxes by Canada have fallen from 15 to 7 per cent over the period, while France has levied a constant 5 per cent.

\footnotetext{
${ }^{50}$ The US operates a more complicated credit system than the other countries covered in this report (see Arnold, Li and Sandler (1996) for details). Despite that, this system is modelled in the same way as other credit systems. The fact that the US pools foreign source income does not affect the calculations since this method only considers an investment in one country at a time. The US system attempts to redefine the base on which foreign taxes were levied to bring them in line with US definitions. This would make a difference to our calculations, but this has not been modelled.
} 
The EMTR on outward investment from the US declines slightly over the period, in contrast to both the domestic EMTR and the EMTR on inward investment into the US, which both increase. By the end of the period, the EMTR for a US firm investing abroad is less than that for a foreign firm investing in the US. The EATR on outward investment also falls, and throughout the period is very similar to the EATR on inward investment.

The final column of Table L. 3 shows the average tax rate calculated using data from company accounts, where the tax rate for each firm is defined as the ratio of provision for tax to net pre-tax income and the median of those tax rates is presented here. The ATR does not change dramatically, but falls from 38 to 33 per cent between 1985 and 1994, occasionally falling as low as 31 per cent. In contrast, the EATR for US multinationals investing abroad fell between 1985 and 1988.

The standard deviation on both the inward EMTR and the inward EATR rise over the period, indicating that there is a lesser degree of capital import neutrality by the end of the period than at the beginning. In contrast to this, the standard deviation on the outward EMTR falls, indicating that the degree of capital export neutrality has increased over the period. This is not corroborated by the standard deviation on the EATR or ATR, both of which remain fairly constant.

Figures L.1 and L.2 show the total amounts of foreign direct investment, both into and out of the US, measured in millions of 1985 US dollars. For ease of presentation, the sources and destinations of the FDI have been broken down by geographic region of the countries covered in the study: Europe, Canada and a separate group for Australia and Japan. A total for the world is also given (this includes all countries, not just 


\section{Taxing profits in a changing world}

FIGURE L. 1

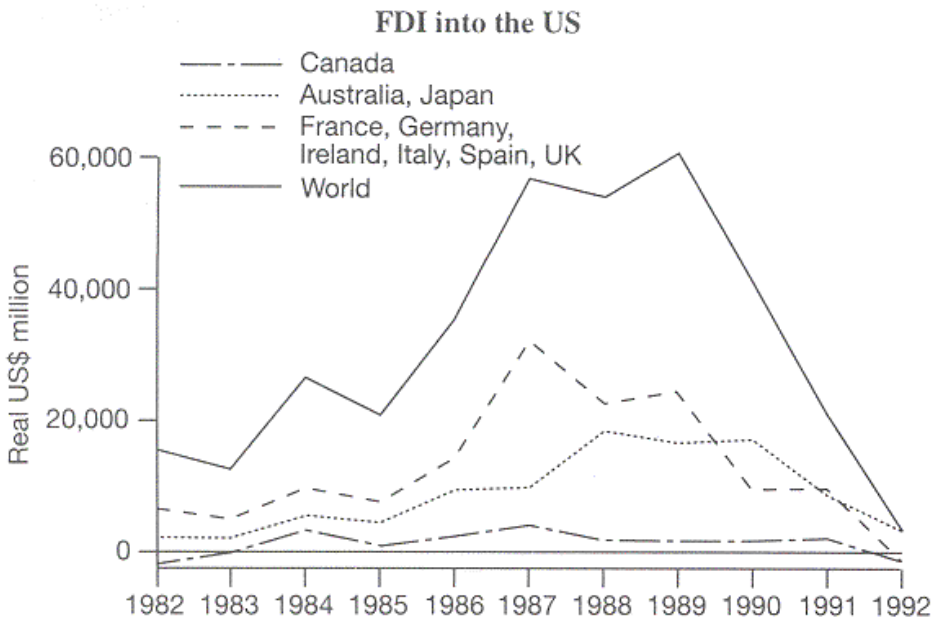

Sources: OECD International Direct Investment Statistics 1982-1993 database; exchange rate and US GDP deflator from OECD Economic Outlook.

FIGURE L.2

FDI from the US

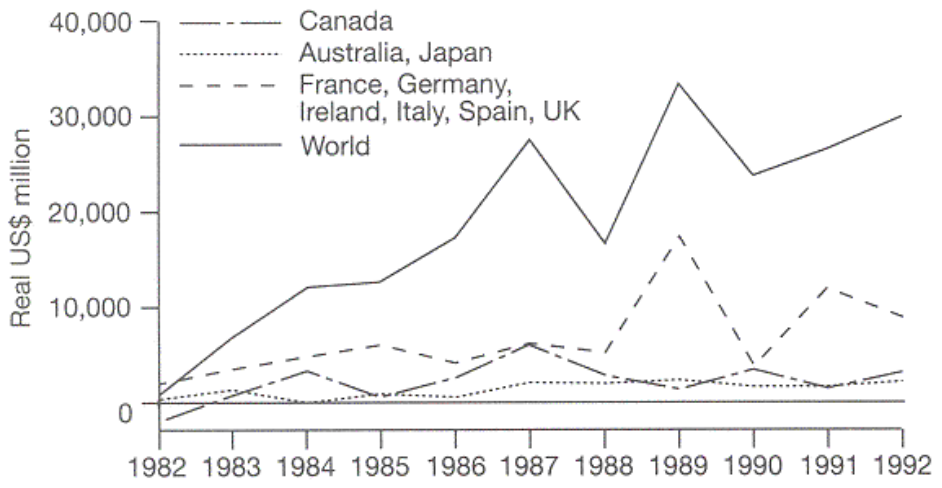

Sources: OECD International Direct Investment Statistics 1982-1993 database; exchange rate and US GDP deflator from OECD Economic Outlook. 
those covered in this study). The flow of FDI into the US grew throughout the early 1980s, but fell dramatically in the early 1990s, reaching below its 1982 level. Outward investment from the US has increased fairly steadily over the period, by contrast, only falling in 1988 and 1990. 


\section{REFERENCES}

Arnold, B., Li, J. and Sandler, D. (1996), 'Comparison and assessment of the tax treatment of foreign-source income in Canada, Australia, France, Germany and the United States', Working Paper no. 96-1 for the Technical Committee on Business Taxation, Canadian Department of Finance.

Bond, E. W. and Samuelson, L. (1989), 'Strategic behaviour and the rules for international taxation of capital', Economic Journal, vol. 99, pp. 1099-111.

Bucovetsky, S. (1991), 'Asymmetric tax competition', Journal of Urban Economics, vol. 30, pp. 167-81.

- and Wilson, J. D. (1991), 'Tax competition with two tax instruments', Regional Science and Urban Economics, vol. 21, pp. $333-50$.

Collins, J. H. and Shackelford, D. A. (1995), 'Corporate domicile and average effective tax rates: the cases of Canada, Japan, the UK and USA', International Tax and Public Finance, vol. 2, pp. 55-83.

Devereux, M. P. (1996a), 'Tax competition and the impact on capital flows', in H. Siebert (ed.), Locational Competition in the World Economy, Institut für Weltwirtschaft an der Universität Kiel.

- (1996b), 'Investment, saving, and taxation in an open economy', Oxford Review of Economic Policy, vol. 12, no. 2, pp. 92-108.

- and Griffith, R. (1996), 'Taxes and the location of production: evidence from a panel of US multinationals', Institute for Fiscal Studies, Working Paper no. 96-14.

— and — (1997), 'Effective average tax rates', mimeo, Institute for Fiscal Studies.

- and Pearson, M. (1995), 'European tax harmonisation and production efficiency', European Economic Review, vol. 39, pp. 1657-82.

Feldstein, M. and Hartman, D. (1979), 'The optimal taxation of foreign source income', Quarterly Journal of Economics, vol. 93, pp. 613-29.

- and Horioka, C. (1980), 'Domestic savings and international capital flows', Economic Journal, vol. 90, pp. 314-29. 
Gordon, R. H. (1986), 'Taxation of investment and savings in a world economy', American Economic Review, vol. 76, pp. 1086-102.

- (1992), 'Can capital income taxes survive in open economies?', Journal of Finance, vol. 47, pp. 1159-80.

- (1997), 'High personal tax rates and entrepreneurial activity: theory and preliminary evidence for the US', paper presented at Warwick Public Economics Seminar, April.

- and Bovenberg, L. (1996), 'Why is capital so immobile internationally? Possible explanations and implications for capital income taxation', American Economic Review, vol. 86, pp. 1057-74.

- and MacKie-Mason, J. K. (1997), 'Why is there corporation taxation in a small open economy? The role of transfer pricing and income shifting', in M. Feldstein and J. Hines (eds), Issues in International Taxation, Chicago: University of Chicago Press, forthcoming.

- and Slemrod, J. (1988), 'Do we collect any revenue from taxing capital income?', Tax Policy and the Economy, vol. 2, pp. 89130.

- and Varian, H. R. (1989), 'Taxation of asset income in the presence of a world securities market', Journal of International Economics, vol. 26, pp. 205-26.

Haufler, A. and Wooton, I. (1996), 'Country size and tax competition for foreign direct investment', mimeo presented at IFS conference on International Capital Taxation, June.

Janeba, E. (1994), 'Tax competition in imperfectly competitive markets', HCM conference on Fiscal Implications of European Integration, Barcelona, May.

- (1995), 'Corporate income tax competition, double taxation treaties and foreign direct investment', Journal of Public Economics, vol. 56, pp. 311-26.

Jorgenson, D. and Landau, R. (eds) (1993), Tax Reform and the Cost of Capital: An International Comparison, Washington DC: The Brookings Institution.

Keen, M. (1996), 'The welfare economics of tax coordination in the European community', in M. Devereux (ed.), The Economics of Tax Policy, Oxford: Oxford University Press.

King, M. A. and Fullerton, D. (1984), The Taxation of Income from Capital, Chicago: University of Chicago Press.

Levinsohn, J. and Slemrod, J. (1993), 'Taxes, tariffs and the global corporation', Journal of Public Economics, vol. 51, pp. 97-116. 


\section{Taxing profits in a changing world}

Oates, W. E. (1972), Fiscal Federalism, New York: Harcourt Brace Jovanovich.

OECD (1991), Taxing Profits in a Global Economy, Paris: Organisation for Economic Co-operation and Development.

- (1996), Public Support to Industry: Report by the Industry Committee to the Council at Ministerial Level, Paris: Organisation for Economic Co-operation and Development.

Razin, A. and Sadka, E. (1991), 'International tax competition and gains from tax harmonization', Economics Letters, vol. 37, pp. 69-76.

Richman, P. (1963), The Taxation of Foreign Investment Income: An Economic Analysis, Baltimore: John Hopkins Press.

Ruding Committee (1992), Report of the Committee of Independent Experts on Company Taxation, Brussels: European Commission.

Wilson, J. D. (1991), 'Tax competition with interregional differences in factor endowments', Regional Science and Urban Economics, vol. 21, pp. 423-51.

Zodrow, G. R. and Mieszkowski, P. (1986), 'Pigou, Tiebout, property taxation and the underprovision of local public goods', Journal of Urban Economics, vol. 19, pp. 356-70. 